Prepared in cooperation with the Middle Pecos Groundwater Conservation District, Pecos County, City of Fort Stockton, Brewster County, and Pecos County Water Control and Improvement District No. 1

\title{
A Conceptual Model of the Hydrogeologic Framework, Geochemistry, and Groundwater-Flow System of the Edwards-Trinity and Related Aquifers in the Pecos County Region, Texas
}

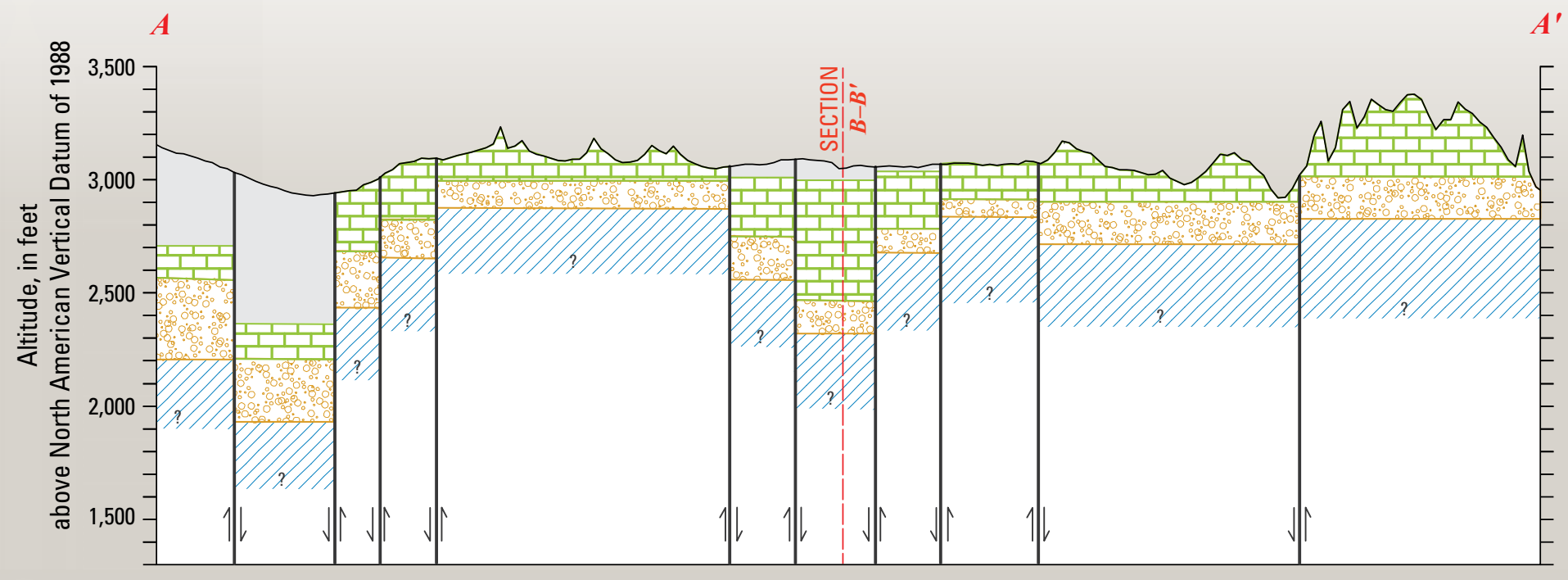

Scientific Investigations Report 2012-5124

(Revised July 10, 2012)

U.S. Department of the Interior

U.S. Geological Survey 



\section{A Conceptual Model of the Hydrogeologic Framework, Geochemistry, and Groundwater-Flow System of the Edwards- Trinity and Related Aquifers in the Pecos County Region, Texas}

By Johnathan R. Bumgarner, Gregory P. Stanton, Andrew P. Teeple, Jonathan V.

Thomas, Natalie A. Houston, Jason D. Payne, and MaryLynn Musgrove

Prepared in cooperation with the Middle Pecos Groundwater Conservation District, Pecos County, City of Fort Stockton, Brewster County, and Pecos County Water Control and Improvement District No. 1

Scientific Investigations Report 2012-5124

(Revised July 10, 2012) 


\title{
U.S. Department of the Interior \\ KEN SALAZAR, Secretary \\ U.S. Geological Survey \\ Marcia K. McNutt, Director
}

\author{
U.S. Geological Survey, Reston, Virginia: 2012 \\ (Revised July 10, 2012)
}

\author{
This and other USGS information products are available at http://store.usgs.gov/ \\ U.S. Geological Survey \\ Box 25286, Denver Federal Center \\ Denver, CO 80225 \\ To learn about the USGS and its information products visit http://www.usgs.gov/ \\ 1-888-ASK-USGS
}

\footnotetext{
Any use of trade, product, or firm names is for descriptive purposes only and does not imply endorsement by the U.S. Government.

Although this report is in the public domain, permission must be secured from the individual copyright owners to reproduce any copyrighted materials contained within this report.
}

Suggested citation:

Bumgarner, J.R., Stanton, G.P., Teeple, A.P., Thomas, J.V., Houston, N.A., Payne, J.D., and Musgrove, MaryLynn, 2012, A conceptual model of the hydrogeologic framework, geochemistry, and groundwater-flow system of the EdwardsTrinity and related aquifers in the Pecos County region, Texas: U.S. Geological Survey Scientific Investigations Report 2012-5124 (revised July 10, 2012), 74 p. 


\section{Contents}

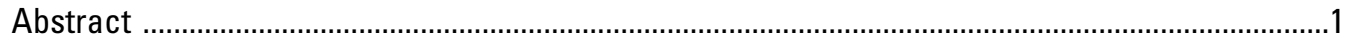

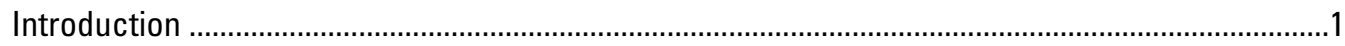

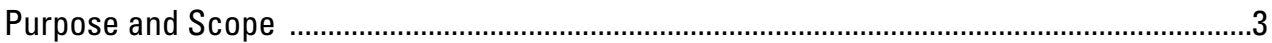

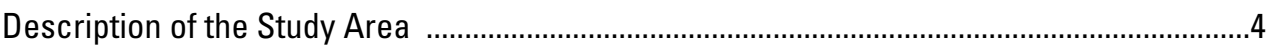

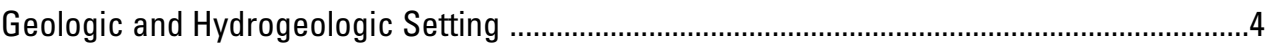

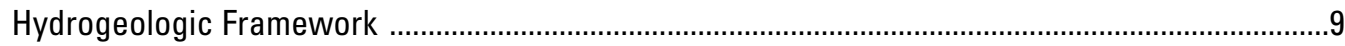

Interpretive Methods of the Hydrostratigraphic Analysis ......................................................

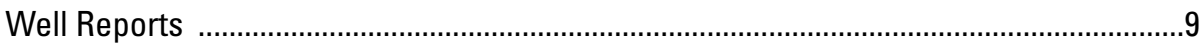

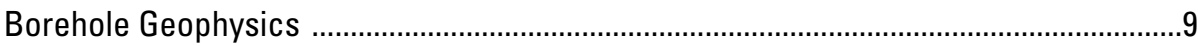

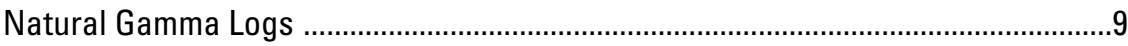

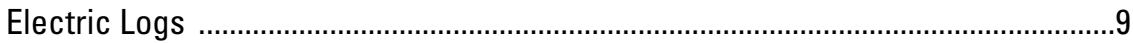

Electromagnetic Induction Logs .................................................................

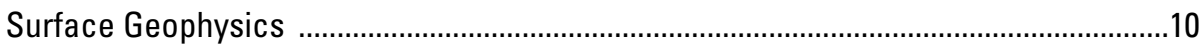

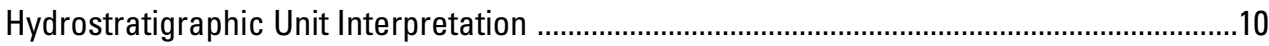

Structural Interpretations ............................................................................................

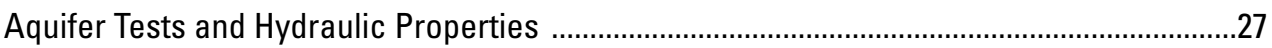

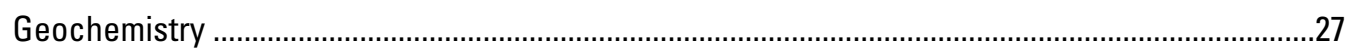

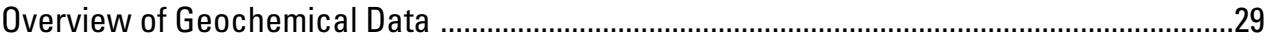

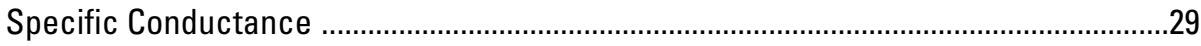

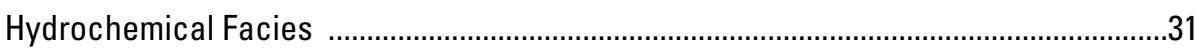

Sulfate and Chloride Concentrations .........................................................................31

Silica Concentrations ..................................................................................................

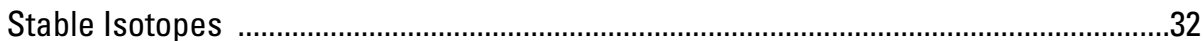

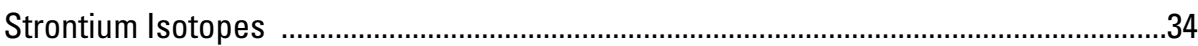

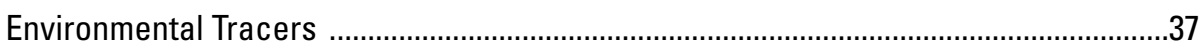

Organic Compounds and Nutrients .........................................................................

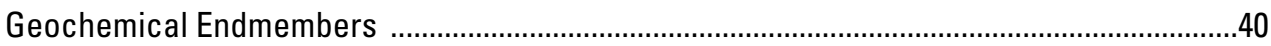

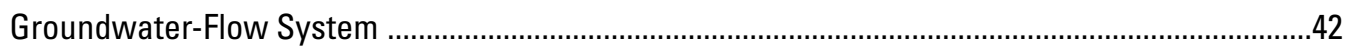

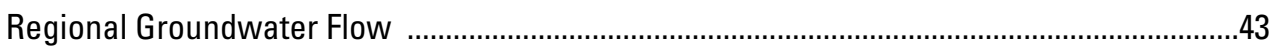

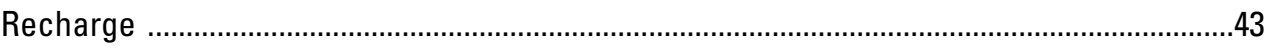

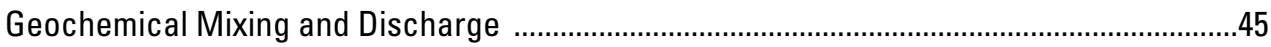

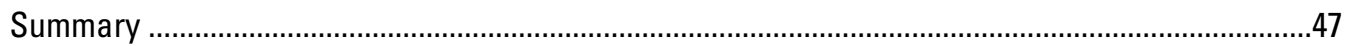

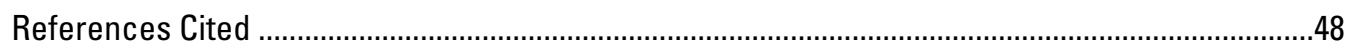

\section{Figures}

1. Map showing location and physiographic provinces of the Pecos County region study area in the Trans-Pecos region, Texas

2. Map showing generalized boundaries of geologic structural features in the Pecos

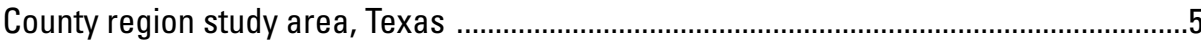

3. Map showing major aquifers in the Pecos County region study area, Texas ..................7

4. Map showing minor aquifers in the Pecos County region study area, Texas ...................8 
5. Example log for well 304711103003301 showing natural gamma, and induction conductivity/resistivity borehole geophysical properties, time-domain electromagnetic (TDEM) soundings, and stratigraphic layers for the Pecos County region study area, Texas

6. Example log for well 302630102503801 showing natural gamma borehole geophysical properties, audio-magnetotelluric sounding (AMT08), and stratigraphic layers in the Pecos County region study area, Texas

7. Map showing locations where geological and geophysical data were used to determine the tops and bases (picks) of hydrostratigraphic subdivisions in the Pecos County region study area, Texas

8. Example logs with geophysical properties of Permian, Triassic, and Cretaceousage stratigraphic layers in $A$, northern Pecos County and $B$, northwestern Pecos County in the Pecos County region study area, Texas

9. Schematic showing the procedure to develop layered-earth electrical scenarios for the audio-magnetotelluric smooth inverse modeling results for the Pecos County region study area, Texas

10. Schematic diagram of three $(A, B$, and $C)$ layered-earth electrical scenarios for the Pecos County region study area, Texas

11. Map showing the altitude of the top surface of the Edwards-Trinity aquifer estimated by interpolating the tops and bases of hydrostratigraphic subdivisions in the Pecos County region study area, Texas

12. Map showing the altitude of the top surface of the Trinity part of the EdwardsTrinity aquifer estimated by interpolating the tops and bases of hydrostratigraphic subdivisions in the Pecos County region study area, Texas

13. Map showing the altitude of the base surface of the Edwards-Trinity aquifer estimated by interpolating the tops and bases of hydrostratigraphic subdivisions in the Pecos County region study area, Texas

14. Map showing the thickness of the Edwards-Trinity aquifer in the Pecos County region study area, Texas, calculated as the difference between the altitudes of the top and base surfaces of the Edwards-Trinity aquifer

15. Map showing the thickness of the Edwards part of the Edwards-Trinity aquifer in the Pecos County region study area, Texas, calculated as the difference between the altitudes of the top and base surfaces of the Edwards part of the EdwardsTrinity aquifer

16. Map showing the thickness of the Trinity part of the Edwards-Trinity aquifer in the Pecos County region study area, Texas, calculated as the difference between the altitudes of the top and base surfaces of the Trinity part of the EdwardsTrinity aquifer

17. Generalized map and detailed cross section $A-A^{\prime}$ in the Pecos County region study area, Texas

18. Generalized map and detailed cross section $B-B^{\prime}$ in the Pecos County region study area, Texas

19. Map showing the log of transmissivity values calculated and estimated using aquifer-test data from wells completed in the Edwards-Trinity aquifer in the Pecos County region study area, Texas

20. Map showing locations of groundwater-well and spring sites for geochemical data collection in the Pecos County region study area, Texas

21. Trilinear diagram showing relations between major cations and anions in groundwater and spring water collected in the Pecos County region study area, Texas 
22. Graph showing relation between sulfate concentrations and chloride concentrations for samples collected from groundwater and spring sites in the Pecos County region study area, Texas

23. Map showing relation between oxygen-18/oxygen-16 and hydrogen-2/hydrogen-1 isotopic ratios for samples collected from groundwater and spring sites in the Pecos County region study area, Texas, and the global meteoric water line

24. Map showing oxygen-18/oxygen-16 isotopic ratios for samples collected from groundwater and spring sites in the Pecos County region study area, Texas

25. Graph showing relation between strontrium-87/strontium-86 isotopic ratio and strontium concentration for groundwater and spring samples collected in the Pecos County region study area, Texas

26. Map showing strontium-87/strontium-86 isotopic ratios for samples collected from groundwater and spring sites in the Pecos County region study area, Texas

27. Map showing national Land Cover Database 2006 land-cover categories in the Pecos County region study area, Texas

28. Map showing potentiometric-surface map of the Edwards-Trinity aquifer developed using the average of the winter (November through April) groundwater-level data collected at each site for 1980-2010 in the Pecos County region study area, Texas .....44

\section{Tables}

1. Hydrostratigraphic section in the Pecos County region study area, Texas

2. Sites contributing well reports, borehole geophysical logs, and surface geophysical soundings used to determine the lithologies, hydrostratigraphic units, and tops and bases of the hydrostratigraphic units in the Pecos County region study area, Texas

3. Location of geophysical soundings and the nearby borehole geophysical log the sounding was compared to in the Pecos County region study area, Texas

4. Compiled transmissivity values using data from aquifer tests conducted at wells completed in the Edwards-Trinity aquifer in or near the Pecos County region study area, Texas

5. Data-collection sites providing data for the geochemical analysis in the Pecos County region study area, Texas

6. Contributing-aquifer revisions for groundwater wells providing data for the geochemical analysis based on the comparison of well production depths with the hydrostratigraphy of hydrogeologic framework for the Pecos County region study area, Texas

7. Summary of selected physical properties and constituents measured in groundwater and spring water samples and hydrochemical facies, Pecos County region study area, Texas.

8. Tritium concentrations and helium-4 screen interpretations for groundwater samples collected in the Pecos County region study area, Texas

9. Average winter (November through April) groundwater-level data used for the 1980-2010 compiled potentiometric-surface map of the Edwards-Trinity aquifer in the Pecos County region study area, Texas 


\section{Conversion Factors}

\section{Inch/Pound to SI}

\begin{tabular}{|c|c|c|}
\hline Multiply & By & To obtain \\
\hline \multicolumn{3}{|c|}{ Length } \\
\hline inch (in.) & 25.4 & millimeter (mm) \\
\hline foot $(\mathrm{ft})$ & 0.3048 & meter $(\mathrm{m})$ \\
\hline mile (mi) & 1.609 & kilometer $(\mathrm{km})$ \\
\hline \multicolumn{3}{|c|}{ Area } \\
\hline square mile $\left(\mathrm{mi}^{2}\right)$ & 2.590 & square kilometer $\left(\mathrm{km}^{2}\right)$ \\
\hline \multicolumn{3}{|c|}{ Flow rate } \\
\hline foot per day (ft/d) & 0.3048 & meter per day $(\mathrm{m} / \mathrm{d})$ \\
\hline cubic foot per second $\left(\mathrm{ft}^{3} / \mathrm{s}\right)$ & 0.02832 & cubic meter per second $\left(\mathrm{m}^{3} / \mathrm{s}\right)$ \\
\hline gallon per minute (gal/min) & 0.06309 & liter per second $(\mathrm{L} / \mathrm{s})$ \\
\hline gallon per day (gal/d) & 0.003785 & cubic meter per day $\left(\mathrm{m}^{3} / \mathrm{d}\right)$ \\
\hline \multicolumn{3}{|c|}{ Radioactivity } \\
\hline picocurie per liter $(\mathrm{pCi} / \mathrm{L})$ & 0.037 & becquerel per liter $(\mathrm{Bq} / \mathrm{L})$ \\
\hline \multicolumn{3}{|c|}{ Specific capacity } \\
\hline $\begin{array}{l}\text { gallon per minute per foot } \\
[(\mathrm{gal} / \mathrm{min}) / \mathrm{ft})]\end{array}$ & 0.2070 & $\begin{array}{l}\text { liter per second per meter } \\
{[(\mathrm{L} / \mathrm{s}) / \mathrm{m}]}\end{array}$ \\
\hline \multicolumn{3}{|c|}{ Hydraulic conductivity } \\
\hline foot per day $(\mathrm{ft} / \mathrm{d})$ & 0.3048 & meter per day $(\mathrm{m} / \mathrm{d})$ \\
\hline \multicolumn{3}{|c|}{ Hydraulic gradient } \\
\hline foot per mile (ft/mi) & 0.1894 & meter per kilometer $(\mathrm{m} / \mathrm{km})$ \\
\hline \multicolumn{3}{|c|}{ Transmissivity* } \\
\hline foot squared per day $\left(\mathrm{ft}^{2} / \mathrm{d}\right)$ & 0.09290 & meter squared per day $\left(\mathrm{m}^{2} / \mathrm{d}\right)$ \\
\hline $\begin{array}{l}\text { gallon per day per foot of draw- } \\
\text { down }(\mathrm{gal} / \mathrm{d} / \mathrm{ft})\end{array}$ & 0.01242 & meter squared per day $\left(\mathrm{m}^{2} / \mathrm{d}\right)$ \\
\hline
\end{tabular}

Temperature in degrees Celsius $\left({ }^{\circ} \mathrm{C}\right)$ may be converted to degrees Fahrenheit $\left({ }^{\circ} \mathrm{F}\right)$ as follows:

$$
{ }^{\circ} \mathrm{F}=\left(1.8 \times{ }^{\circ} \mathrm{C}\right)+32
$$

Temperature in degrees Fahrenheit $\left({ }^{\circ} \mathrm{F}\right)$ may be converted to degrees Celsius $\left({ }^{\circ} \mathrm{C}\right)$ as follows:

$$
{ }^{\circ} \mathrm{C}=\left({ }^{\circ} \mathrm{F}-32\right) / 1.8
$$

Vertical coordinate information is referenced to the North American Vertical Datum of 1988 (NAVD88).

Horizontal coordinate information is referenced to the North American Datum of 1983 (NAD83). Altitude, as used in this report, refers to distance above the vertical datum.

*Transmissivity: The standard unit for transmissivity is cubic foot per day per square foot times foot of aquifer thickness [(ft $\left./ \mathrm{d}) / \mathrm{ft}^{2}\right] \mathrm{ft}$. In this report, gallon per day per foot of drawdown (gpd/ft) is used for convenience.

Specific conductance is given in microsiemens per centimeter at 25 degrees Celsius $(\mu \mathrm{S} / \mathrm{cm}$ at $\left.25^{\circ} \mathrm{C}\right)$. 
Concentrations of chemical constituents in water are given either in milligrams per liter (mg/L) or micrograms per liter $(\mu \mathrm{g} / \mathrm{L})$.

Tritium concentrations are given in units of picocuries per liter ( $\mathrm{pCi} / \mathrm{L}$ ) and Tritium Units (TU). Based upon a tritium half-life of 12.32 years $1 \mathrm{TU}$ is equal to $3.22 \mathrm{pCi} / \mathrm{L}$ (Lucas and Unterweger, 2000).

\section{Explanation of Isotope Units}

The values for stable-isotope ratios discussed in this report are referenced to the following standard materials:

\begin{tabular}{|c|c|c|}
\hline Element & Ratio & Standard identity and reference \\
\hline Hydrogen & Hydrogen-2/hydrogen-1 & $\begin{array}{l}\text { Vienna Standard Mean Ocean Water (VSMOW) (Casciotti and } \\
\text { others, 2002) }\end{array}$ \\
\hline Oxygen & Oxygen-18/oxygen-16 & $\begin{array}{l}\text { Vienna Standard Mean Ocean Water (VSMOW) (Casciotti and } \\
\text { others, 2002) }\end{array}$ \\
\hline
\end{tabular}





\title{
A Conceptual Model of the Hydrogeologic Framework, Geochemistry, and Groundwater-Flow System of the Edwards-Trinity and Related Aquifers in the Pecos County Region, Texas
}

\author{
By Johnathan R. Bumgarner, Gregory P. Stanton, Andrew P. Teeple, Jonathan V. Thomas, Natalie A. Houston, \\ Jason D. Payne, and MaryLynn Musgrove
}

\section{Abstract}

A conceptual model of the hydrogeologic framework, geochemistry, and groundwater-flow system of the EdwardsTrinity and related aquifers, which include the Pecos Valley, Igneous, Dockum, Rustler, and Capitan Reef aquifers, was developed as the second phase of a groundwater availability study in the Pecos County region in west Texas. The first phase of the study was to collect and compile groundwater, surface-water, water-quality, geophysical, and geologic data in the area. The third phase of the study involves a numerical groundwater-flow model of the Edwards-Trinity aquifer in order to simulate groundwater conditions based on various groundwater-withdrawal scenarios. Resource managers plan to use the results of the study to establish management strategies for the groundwater system.

The hydrogeologic framework is composed of the hydrostratigraphy, structural features, and hydraulic properties of the groundwater system. Well and geophysical logs were interpreted to define the top and base surfaces of the Edwards-Trinity aquifer units. Elevations of the top and base of the Edwards-Trinity aquifer generally decrease from the southwestern part of the study area to the northeast. The thicknesses of the Edwards-Trinity aquifer units were calculated using the interpolated top and base surfaces of the hydrostratigraphic units. Some of the thinnest sections of the aquifer were in the eastern part of the study area and some of the thickest sections were in the Pecos, Monument Draw, and Belding-Coyanosa trough areas. Normal-fault zones, which formed as growth and collapse features as sediments were deposited along the margins of more resistant rocks and as overlying sediments collapsed into the voids created by the dissolution of Permian-age evaporite deposits, were delineated based on the interpretation of hydrostratigraphic cross sections. The lowest aquifer transmissivity values were measured in the eastern part of the study area; the highest transmissivity values were measured in a faulted area of the Monument Draw trough. Hydraulic conductivity values generally exhibited the same trends as the transmissivity values.

Groundwater-quality data and groundwater-level data were used in context with the hydrogeologic framework to assess the chemical characteristics of water from different sources, regional groundwater-flow paths, recharge sources, the mixing of water from different sources, and discharge in the study area. Groundwater-level altitudes generally decrease from southwest to northeast and regional groundwater flow is from areas of recharge south and west to the north and northeast. Four principal sources of recharge to the Edwards-Trinity aquifer were identified: (1) regional flow that originated as recharge northwest of the study area, (2) runoff from the Barilla, Davis, and Glass Mountains, (3) return flow from irrigation, and (4) upwelling from deeper aquifers. Results indicated Edwards-Trinity aquifer water in the study area was dominated by mineralized, regional groundwater flow that most likely recharged during the cooler, wetter climates of the Pleistocene with variable contributions of recent, local recharge. Groundwater generally flows into the down-dip extent of the Edwards-Trinity aquifer where it discharges into overlying or underlying aquifer units, discharges from springs, discharges to the Pecos River, follows a regional flow path east out of the study area, or is withdrawn by groundwater wells. Structural features such as mountains, troughs, and faults play a substantial role in the distribution of recharge, local and regional groundwater flow, spring discharge, and aquifer interaction.

\section{Introduction}

The Edwards-Trinity aquifer is a vital groundwater resource for agricultural, industrial, and municipal uses in the Trans-Pecos region of west Texas (fig. 1) (Barker and Ardis, 1996; Freese and Nichols, LBG-Guyton, 2010). A better 


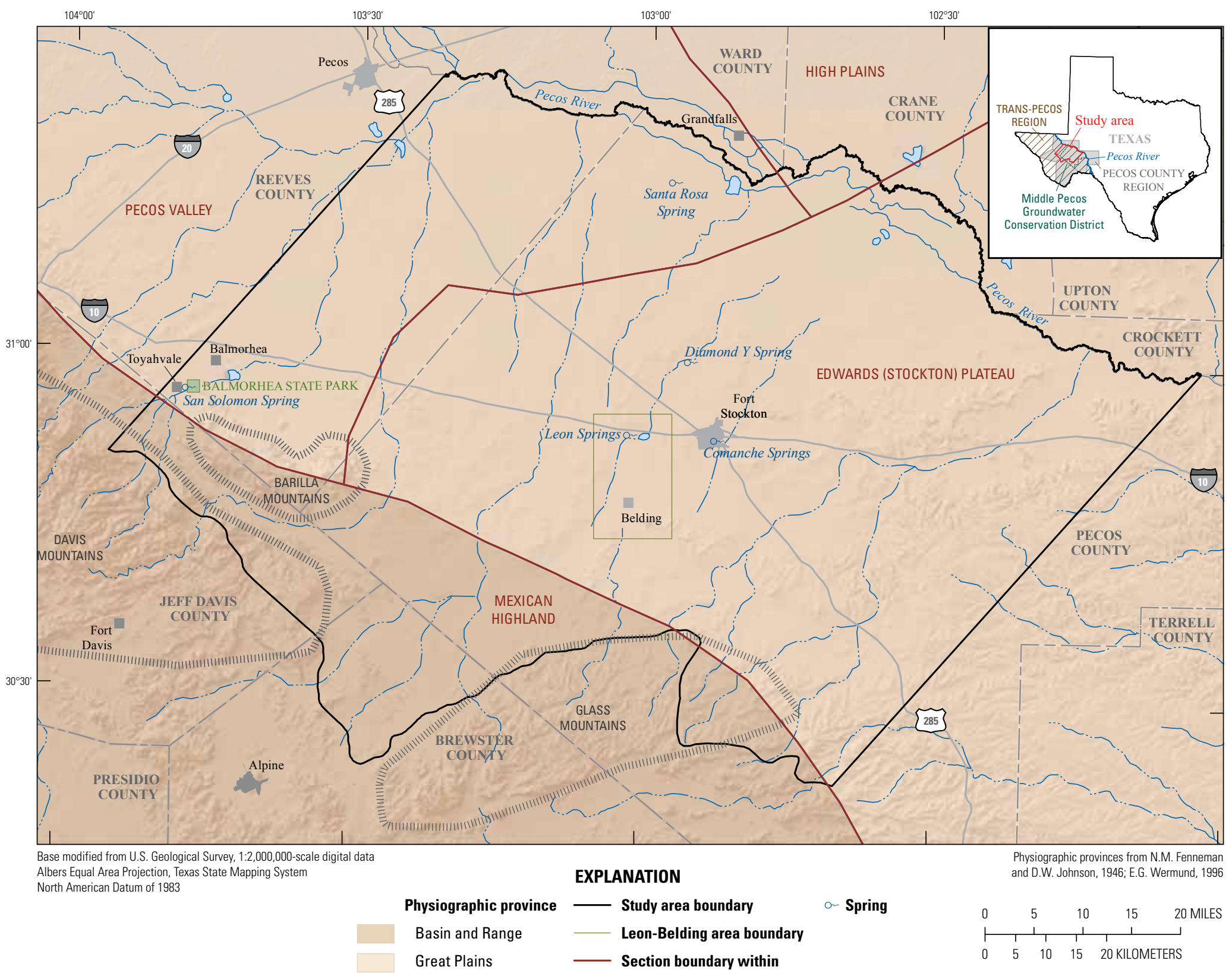

physiographic province

Figure 1. Location and physiographic provinces of the Pecos County region study area in the Trans-Pecos region, Texas. 
understanding of the hydrogeologic setting and processes that control the distribution, quality, and availability of water in the aquifer is required for optimal resource management. In general, a comprehensive, integrated analysis of available scientific data facilitates a better understanding of an aquifer system, which enables water-resource managers to establish long-range and short-range aquifer management strategies that support present and projected aquifer uses. Resource managers would like to know more about the future availability of water in the Edwards-Trinity aquifer in Pecos County, Texas, and the effects of the possible increase or temporal redistribution of groundwater withdrawals. In order to provide resource managers with that knowledge, the U.S. Geological Survey (USGS), in cooperation with the Middle Pecos Groundwater Conservation District, Pecos County, City of Fort Stockton, Brewster County, and Pecos County Water Control and Improvement District No. 1, completed a comprehensive, integrated analysis of available hydrogeologic data in order to develop a conceptual model of the EdwardsTrinity and related aquifers in the study area in parts of Brewster, Crane, Crockett, Jeff Davis, Pecos, Reeves, Terrell, and Ward Counties (hereinafter referred to as the Pecos County region study area) (fig. 1). The Edwards-Trinity and related aquifers (hereinafter referred to as the groundwater system) include the Pecos Valley, Igneous, Dockum, Rustler, and Capitan Reef aquifers. The Edwards-Trinity aquifer was the focus of the investigation presented in this report, and the related aquifers were studied in terms of how they potentially interact with and affect the Edwards-Trinity aquifer.

Development of the conceptual model is the second phase of a three-phase groundwater-availability study being conducted in the Pecos County region by the USGS and the cooperators. The first phase was to collect groundwater, surface-water, geochemical, geophysical, and geologic data in the study area and develop a geodatabase of historical and collected data (Pearson and others, 2012). The data compiled in the first phase of the study were used in this report to develop the conceptual model. The third phase of the study involves a numerical groundwater-flow model of the EdwardsTrinity aquifer in order to simulate groundwater conditions based on various groundwater-withdrawal scenarios.

The conceptual model of the hydrogeologic framework, geochemistry, and groundwater-flow system in the 4,700 square-mile $\left(\mathrm{mi}^{2}\right)$ study area was developed in an effort to better understand the groundwater system and establish a scientific foundation for resource-management decisions. Lithologic information obtained from well reports and geophysical data was used to describe the hydrostratigraphy and structural features of the groundwater system and aquifer-test data were used to estimate aquifer hydraulic properties. Groundwater-quality data (hereinafter referred to as geochemical data) were used to evaluate groundwaterflow paths, water-rock interaction, aquifer interaction, and the mixing of water from different sources. Groundwater-level data were also used to evaluate aquifer interaction as well as to develop a potentiometric-surface map, delineate regional groundwater divides, and describe regional groundwater-flow paths.

Several scientific investigations have been done to collect and compile physical and chemical data, describe the hydrogeologic processes, and develop conceptual and numerical groundwater-flow models of the Edwards-Trinity aquifer in the Trans-Pecos region. Pearson and others (2012) documented the methods used to compile the available groundwater, surface-water, geochemical, geophysical, and geologic information used to develop the conceptual model described in this report. The data compiled by Pearson and others (2012) include existing data in the study area and data collected by the USGS. The Thornhill Group, Inc. (2008) and Daniel B. Stephens and Associates (2010) developed conceptual and numerical groundwater-flow models of the Edwards-Trinity aquifer that focused on $100 \mathrm{mi}^{2}$ near Belding, Tex., referred to hereinafter as the Leon-Belding area (fig. 1). The Leon-Belding area is an agricultural area about 7 miles (mi) southwest of Fort Stockton that includes about $30 \mathrm{mi}^{2}$ of cultivated land. Water primarily from the Edwards-Trinity aquifer is used for irrigation purposes in the Leon-Belding area. Using the conceptual and numerical groundwater-flow models, simulations to project future aquifer conditions in the Leon-Belding area based on various groundwater-withdrawal scenarios were published (Thornhill Group, Inc., 2008; Daniel B. Stephens and Associates, 2010). Anaya and Jones (2009) developed a 44,000- $\mathrm{mi}^{2}$ regional groundwater-flow model of the Edwards-Trinity and Pecos Valley aquifers in central and western Texas to determine the availability of groundwater based on projected needs. As part of the USGS Regional Aquifer Systems Analysis (RASA) program, Barker and Ardis (1996) described the hydrogeologic framework of the Edwards-Trinity aquifer system on a broad, regional scale in west-central Texas that included the Pecos Region study area. Small and Ozuna (1993) investigated the Edwards-Trinity aquifer in the Pecos County region; they broadly described the hydrogeology of the groundwater system, defined the groundwater-level and water-quality characteristics of the aquifer, determined post-development changes in water levels and water quality, and described relations between groundwater levels and flow from Comanche Springs in Fort Stockton, Tex.; Comanche Springs were historically important to this region for water supply and recreation but have not flowed continuously since the 1950s (Small and Ozuna, 1993).

\section{Purpose and Scope}

This report documents the development of a conceptual model of the Edwards-Trinity and related aquifers in the Pecos County region, Tex., using data collected by the USGS during 2009-11 and historical data from 1930-2011 collected by various State and local agencies and compiled by the USGS (Pearson and others, 2012). The parts of the conceptual model are described, including the hydrogeologic 
framework, geochemistry, and groundwater flow of the groundwater system in the study area. The methodologies used for analyzing the well-log and geophysical datasets and the construction of the hydrogeologic framework and the principal chemical properties of water in the study area and geochemical endmembers used to describe the chemical characteristics of water from different sources are described. Finally, the chemical properties of water and groundwater-level information are described in context with the hydrogeologic framework; regional groundwater flow, aquifer recharge, the mixing of water from different sources, and groundwater discharge are qualitatively assessed.

\section{Description of the Study Area}

The study area covers about 4,700 $\mathrm{mi}^{2}$ of the TransPecos region of Texas west of the Pecos River, and its boundaries were defined to include the extent of the fieldcollected data gathered for this study (fig. 1) (Pearson and others, 2012). The southwestern and southern boundaries of the study area are rimmed by the Barilla and Davis Mountains in northeastern Jeff Davis County and southwestern Reeves County and the Glass Mountains in northeastern Brewster County and southern Pecos County. The northeastern boundary of the project study area is the Pecos River, and the southeastern and northwestern boundaries were aligned to the data cells of the Texas Water Development Board (TWDB) Groundwater Availability Model (GAM) of the area (Anaya and Jones, 2009). The southwestern boundary was modified using the "active" part of the GAM model. The western part of the Middle Pecos Groundwater Conservation District (MPGCD) management area (Pecos County is the MPGCD management area) is in the study area. Altitude ranges from 6,350 feet (ft) in the southwestern part of the study area in the Davis Mountains in Jeff Davis County to $2,150 \mathrm{ft}$ in the northeastern part of the study area near the Pecos River in Pecos County. The climate in the study area is arid, characterized by scant rainfall and large amounts of evaporation. The average annual rainfall during 1970-2000 at Fort Stockton was approximately 14 inches (National Weather Service, 2011). Rainfall, as recorded at Fort Stockton, annually is quite variable; during 2000-10, 2004 was the wettest year with an annual rainfall of about 26 inches and 2008 was the driest year with an annual rainfall of about 6 inches (National Weather Service, 2011). Potential annual evaporation of as much as 109 inches has been estimated (Boghici, 1997). Temperatures during 1970-2000 ranged from an average low of about 32 degrees Fahrenheit $\left({ }^{\circ} \mathrm{F}\right)$ in January to an average high of about $96^{\circ} \mathrm{F}$ in July (National Weather Service, 2011). The study area is in the Pecos Valley, Edwards Plateau, and High Plains sections of the Great Plains physiographic province, and the Mexican Highland section of the Basin and Range Province (fig. 1) (Fenneman and Johnson, 1946). West of the Pecos River, the Edwards Plateau section of the Great
Plains Province is also referred to as the Stockton Plateau (Wermund, 1996).

\section{Geologic and Hydrogeologic Setting'}

There were several periods of seawater inundation and erosion during the geologic history of the Trans-Pecos region of west Texas. Sedimentary rocks of Pennsylvania, Permian, Triassic, and Cretaceous age; Tertiary-age igneous rocks; and Cenozoic-age alluvium are present in the subsurface, and many are exposed at the surface in the study area (Texas Water Development Board, 1972). This study focuses on subsurface rocks deposited from the Permian to the Quaternary Period (table 1 at end of report). During the Permian Period, this region of western Texas was a shallow sea; marine sandstones, limestone, and shale were deposited in the basin. In the later part of the Permian Period, the basin became more isolated and the deposition of sediments changed to gypsum, anhydrite, halite, and associated salts. Several geologic structures also formed in the study area during the Permian Period (fig. 2). The Central Basin Platform is a structural high in the northern part of Pecos County that divides the Permian Basin into the Delaware and the Midland Basins (Ashworth, 1990). The Val Verde Basin was separated from the Delaware Basin by the development of a reef complex during the Permian Period (Small and Ozuna, 1993). Dissolution of Permian-age evaporite deposits that began at the time of deposition and continued through the Cretaceous Period caused the Permian beds to collapse and form a north-south depositional trough called the Belding-Coyanosa trough (fig. 2) (Armstrong and McMillion, 1961; Boghici, 1997). By the Triassic Period, the sea retreated and a sequence of nondeposition, erosion, and then deposition of fluvial and deltaic sediments took place. During the Jurassic Period, this region of western Texas was above sea level, erosion was the dominant process, and the land surface was tilted to the southeast (Barker and Ardis, 1996). As a result, there are no Jurassic rocks in the geologic record of the study area. During the Cretaceous Period, sea level once again rose and the deposition of continental sediments changed to shallow marine sediments (Barker and Ardis, 1996). Cretaceous deposition included the filling of the structural troughs that had begun forming in the Permian and Triassic Periods, which resulted in thicker units in these areas. The Cretaceous Period was the last marine deposition event in the study area. Tertiary Period volcanism deposited extrusive igneous rocks following the Cretaceous marine deposition (George, and others, 2011). Continental sediments of sand and gravel were deposited during the Tertiary and Quaternary Periods (Texas Water Development Board, 1972). During the Cenozoic Era, two depositional troughs that roughly trend north-south formed in the central and western parts of the study area because of the continued dissolution

${ }^{1}$ This section modified from Pearson and others (2012, p. 3). 


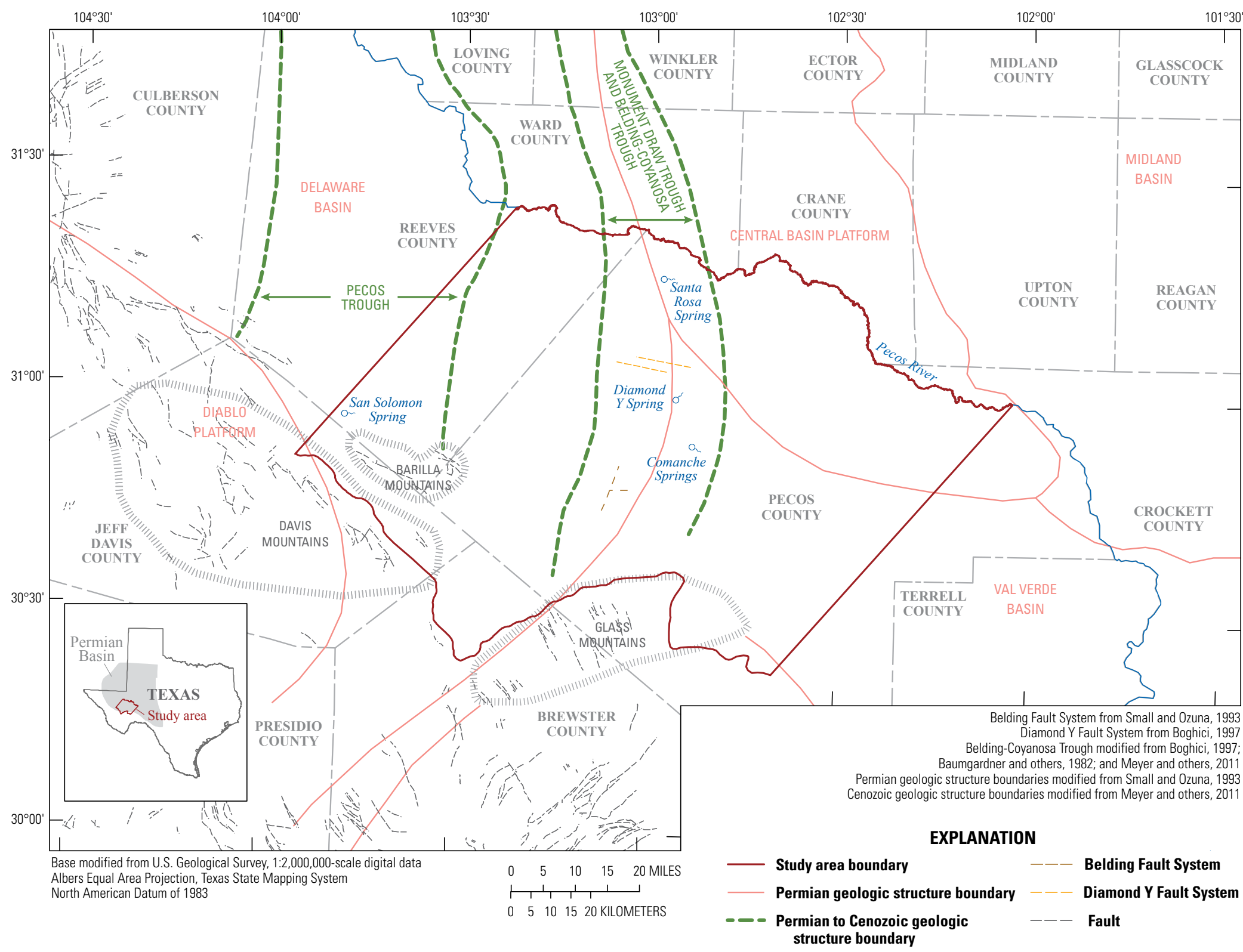

Figure 2. Generalized boundaries of geologic structural features in the Pecos County region study area, Texas. 
of the Permian-age evaporite deposits and collapse of the overlying sediments (Armstrong and McMillion, 1961). These troughs subsequently filled with Cenozoic-age alluvium and are known as the Monument Draw (central) and Pecos (western) troughs (fig. 2). For simplicity, hereinafter, the name "Monument Draw trough" will be used to represent both the Cenozoic-age Monument Draw and Permian to Cretaceousage Belding-Coyanosa troughs because the spatial extents and separation of these structural features are not well defined.

The geologic setting contributed to the formation of two major and four minor aquifers in the study area (figs. 3 and 4, table 1). The Pecos Valley aquifer is a major aquifer composed of Cenozoic-age alluvium consisting of unconsolidated silt, sand, gravel and clay (fig. 3) (Small and Ozuna, 1993). In the northern part of the study area, the Pecos Valley aquifer uncomformably overlies the Edwards-Trinity aquifer, the other major (and primary) aquifer in the study area (fig. 3). Minor aquifers include the Igneous, Dockum, Rustler, and Capitan Reef aquifers (fig. 4). The Igneous aquifer consists of Tertiary-age igneous and volcaniclastic rocks. Located in the southwestern part of the study area, the Igneous aquifer uncomformably overlies the Cretaceous-age Edwards-Trinity aquifer. The Edwards-Trinity aquifer is composed of lower Cretaceous-age rocks of limestone, marl, and clay of the Washita Group; limestone of the Fredericksburg Group; and sand, limestone, and shale of the Trinity Group (fig. 3, table 1). The Edwards part of the aquifer is composed of upper Cretaceous rocks of the Fredericksburg and Washita Groups, which locally are referred to as the Edwards and Sixshooter Groups (Brand and DeFord, 1958; Small and Ozuna, 1993; Smith and others, 2000). The Fort Lancaster Formation, the Burt Ranch Member, and the Fort Terrett Formation make up the Edwards Group and occur in the eastern part of the study area (Rose, 1972; Smith and Brown, 1983; Small and Ozuna, 1993). The Boracho Formation, the University Mesa Marl, which is a facies change equivalent of the Boracho Formation, and the Finlay Formation make up the Sixshooter Group and occur in the western part of Pecos County (Brand and DeFord, 1958; Small and Ozuna, 1993; Smith and others, 2000). The Buda Limestone, which overlies the Boracho Formation, is present east of Fort Stockton. Regionally, the Buda Limestone, the Fort Lancaster Formation, and the Burt Ranch Member form the Washita Group. The Fort Terrett and Finlay Formations form the Fredericksburg Group. The Trinity group is composed of the Maxon Sands, the Glen Rose Formation, and the Basal Cretaceous Sand (Anaya and Jones, 2009). The individual formations in the Trinity Group are not separated for the purposes of this report. Locally the Trinity Group is known as the Trinity Sands (Small and Ozuna, 1993; Rees and Buckner, 1980).

The Dockum aquifer is a minor aquifer and is composed of Triassic-age rocks of the Dockum Group (fig. 4) (Bradley and Kalaswad, 2003). The stratigraphic nomenclature of the Dockum Group has been updated and regionalized in the literature as better information became available (Lehman, 1994a, b; Bradley and Kalaswad, 2003). In Pecos County, a sand unit within the Dockum aquifer is recognizable in some geophysical logs, but the individual formations of the Dockum Group are not separated for the purposes of this report. Locally, the Dockum aquifer is also known as the Santa Rosa aquifer (Small and Ozuna, 1993). The boundaries of the Dockum aquifer are not explicitly defined in this report and might extend beyond the general aquifer boundaries shown in figure 4.

The Rustler and Capitan Reef aquifers are minor aquifers composed of Permian-age rocks (fig. 4). The Rustler aquifer is composed of mostly dolomite, anhydrite, and some limestone of the Rustler Formation. A basal unit consists of sand, conglomerate, and some shale (Small and Ozuna, 1993; LBG-Guyton, 2003). The boundaries of the Rustler aquifer are not explicitly defined in this report and might extend beyond the general aquifer boundaries shown in figure 4 . The Capitan Reef aquifer consists of reef, fore-reef, and backreef facies of dolomite and limestone of the older Capitan Limestone.

Water is supplied to the region from groundwater; the Pecos River, which is the main surface-water drainage and forms the northeastern boundary of the study area; and springs that discharge from groundwater sources. San Solomon Spring in Balmorhea State Park in Reeves County near Toyahvale, Tex., is currently (2012) the largest spring in the Trans-Pecos region (Sharp, 2001). San Solomon Spring provides water for irrigation, recreation, and endangeredspecies habitat (fig. 1) (Texas Water Development Board, 2005). Santa Rosa Spring is near Grandfalls, Tex., and at one time, this spring supplied water for irrigation. Santa Rosa Spring did not flow from the 1950s until the late 1980s, at which time flow resumed at a decreased rate (Freese and Nichols and LBG-Guyton, 2010). Until the 1950s, Comanche Springs were the largest springs in the Trans-Pecos region and sixth largest in the State (Sharp, 2001). Comanche Springs first went dry in 1955 and perennial flow ceased in 1961 (Texas Parks and Wildlife Department, 2012). According to Freese and Nichols and LBG-Guyton (2010), Comanche Springs have flowed occasionally since 1987. Diamond Y Spring, which are located north of Fort Stockton, support habitat for endangered species (Freese and Nichols and LBGGuyton, 2010). The San Solomon, Santa Rosa, Comanche, and Diamond Y Springs were sampled for this study (Pearson and others, 2012). Finally, the four springs are in faulted areas, and it is likely the presence of faults contributed to the formation of the springs (Armstrong and McMillion, 1961; Baumgardner and others, 1982; Small and Ozuna, 1993; Veni, 1991; Boghici, 1997; Sharp and others, 1999; Texas Water Development Board, 2005; Anaya and Jones, 2009). Furthermore, it is likely that structural features such as faults, joints, bedding planes, and fractures influence all of the groundwater-flow components of the groundwater system (that is, recharge, local and regional flow, and discharge), not just spring flow. 


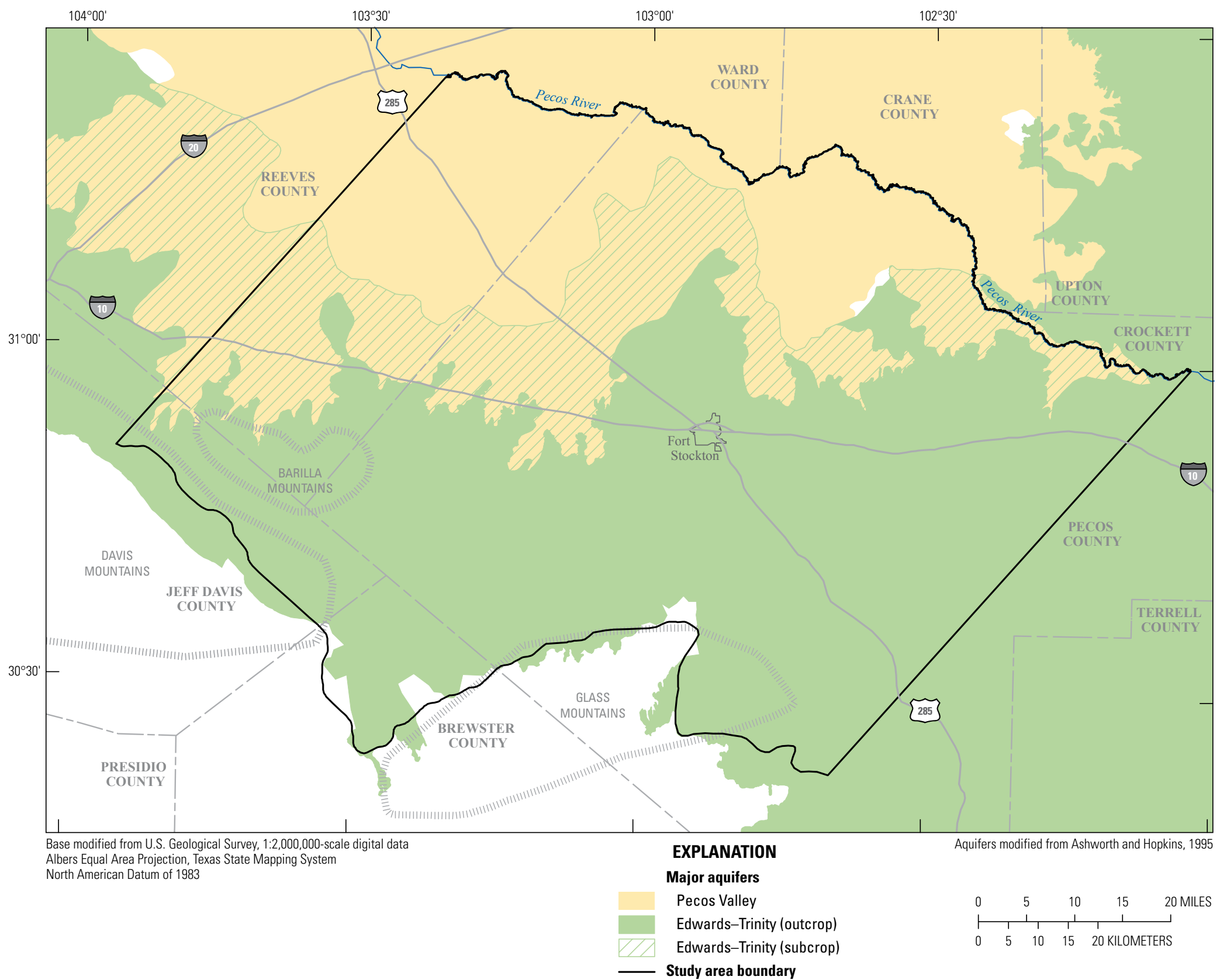

Figure 3. Major aquifers in the Pecos County region study area, Texas. 


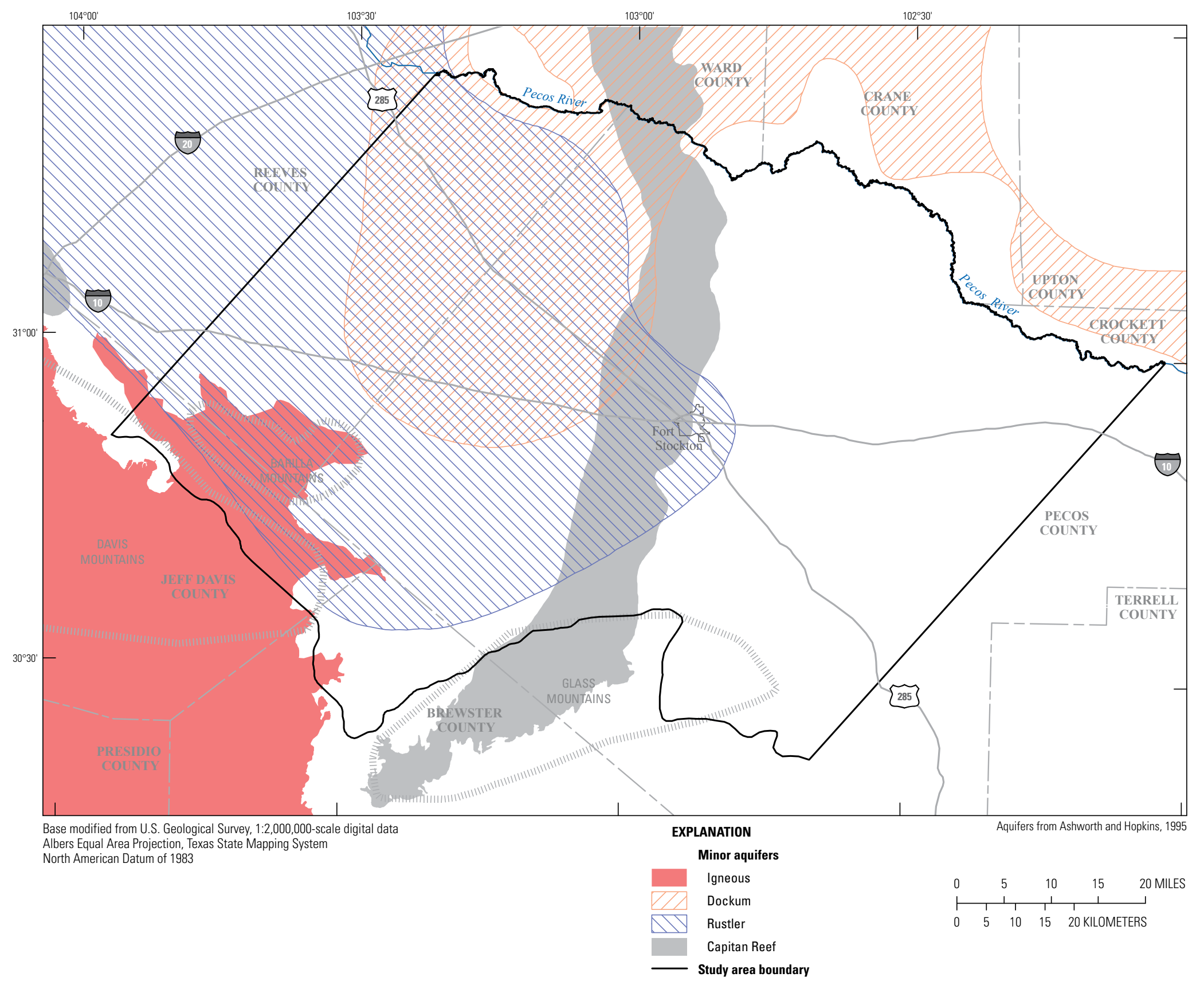

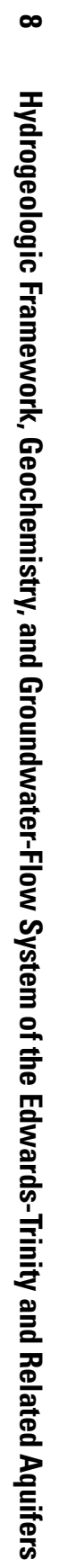

Figure 4. Minor aquifers in the Pecos County region study area, Texas. 


\section{Hydrogeologic Framework}

The hydrogeologic framework of the conceptual model comprises the hydrostratigraphy, structural features, and hydraulic properties of the groundwater system. Well-log data were compiled and supplemented with data gathered through borehole and surface geophysics. The data were then analyzed to map the tops and bases of the hydrostratigraphic units that compose the Edwards-Trinity aquifer and the lateral and vertical relations of overlying and underlying aquifers in order to develop the hydrostratigraphy of the study area (table 1). The data also were used to evaluate the structural features such as bed orientation, unit thickness, and fault zones. The top, base, and thickness of the aquifer, as discussed in this report, refer to the hydrostratigraphic units that compose the aquifer, not just the saturated portion of the hydrostratigraphic units. Aquifer tests were performed and supplemented by historical aquifer-test data to assess the hydraulic properties of the Edwards-Trinity aquifer. Pearson and others (2012) detail the methods used for collection, analysis, and quality control of most of the data used in this report.

\section{Interpretive Methods of the Hydrostratigraphic Analysis}

Well reports, borehole geophysical logs, and surface geophysical soundings (Pearson and others, 2012) were evaluated to determine the lithologies, hydrostratigraphic units, and tops and bases of the hydrostratigraphic units, creating datasets for characterizing vertical and lateral hydrostratigraphic extents. More than 2,000 data records for wells in or near the study area were acquired from various sources and evaluated for applicability to the study. A total of 662 records were found to contain pertinent data of applicable vertical extent within the study area (table 2 at end of report). These records were supplemented by 44 geophysical logs, 4 time-domain electromagnetic (TDEM) soundings, and 13 audio-magnetotelluric (AMT) soundings collected by the USGS as part of the first phase of this study (Pearson and others, 2012). Drilling and well-completion log data from 500 sites were used to help identify the depths to tops and bases of the formations. Depths to the tops and bases of the formations and structural features were entered into a geospatial database by altitude and spatial location for correlation among neighboring wells creating a regional network of correlated points. Geophysical logs are typically reliable sources for subsurface information. Incorrect or missing information including incorrect location information, missing or incorrect header information, unknown well completion, poor tool calibrations, and unsuitable borehole environments can introduce errors during the interpretation of hydrostratigraphic information. Geophysical logs with incorrect or missing information were not used to interpret the hydrostratigraphy.

\section{Well Reports}

Producing zones, well yield, and lithologic characterization were interpreted from 296 well reports. All well reports used in this study have been compiled from Daniel B. Stephens and Associates (2010; 201 data points) and Meyer and others (2011; 95 data points).

\section{Borehole Geophysics}

Borehole geophysical data such as natural gamma, formation resistivity, and caliper are commonly used to characterize and identify stratigraphic units; these data exist for many wells in the study area and were collected during previous scientific investigations, petroleum explorations, or both. The Railroad Commission of Texas (RRC) Geophysical Log Database (Railroad Commission of Texas, 2010) contains 1,979 publicly available well logs in or near the study area; however, most of the well logs did not meet project requirements because the types of geophysical tools that were used did not yield data useful for modeling purposes or the depth interval studied did not include the waterbearing formations. Each geophysical log was evaluated to determine if the log penetrated the desired stratigraphic units and provided useful data for determining the tops and bases of stratigraphic units or data for identifying other structural features. Information used to supplement well reports were 230 borehole geophysical logs ( 28 from University Lands (2011), 23 from USGS, 51 from RRC, and 128 from TWDB). The borehole geophysical logs used to help determine the tops and bases of hydrostratigraphic formations were natural gamma, electric, and electromagnetic induction logs.

\section{Natural Gamma Logs}

Natural gamma logs provide a record of gamma radiation detected at depth in a borehole. Fine-grained sediments that contain abundant clay tend to be more radioactive than quartz-grain sandstones or carbonates (Keys, 1997). The natural gamma, electric, and electromagnetic induction logs collectively can be useful to identify lithologies and contact depths of the strata penetrated in the borehole.

\section{Electric Logs}

Electric logs use a series of electrodes mounted on the downhole probe and a surface electrode in the ground to measure potential (or voltage) that varies with the electrical properties of fluids and rock materials. Electric logs require an uncased, fluid-filled hole to allow the current to flow into the formation. Electric logs include the following data: normal resistivity, lateral resistivity, spontaneous potential, and singlepoint resistance.

Normal resistivity logs are useful for determining and correlating various lithologies but also are affected by the resistivity of the fluids in the borehole and formation (Keys, 
1997). The lateral resistivity log increases the resolution and decreases the effect of adjacent beds in comparison with the normal resistivity logs (Keys, 1990). Spontaneous potential (SP) is one of the oldest logging techniques and uses a very simple method of measuring the potentials produced by various salinity conditions (Keys, 1990). SP is a function of the chemistry of fluids in the borehole and adjacent rocks, the temperature, and the clay present and is not related directly to porosity and permeability (Keys, 1997). The single point resistance (SPR) log uses the same circuitry as SP and shows the resistance measured between the electrode in the well and an electrode at the land surface (Keys, 1990).

\section{Electromagnetic Induction Logs}

Electromagnetic (EM) induction probes measure conductivity in air- or water-filled holes and perform well in open holes or polyvinyl chloride (PVC) cased holes. The measurement of conductivity commonly is reciprocated to provide logs with curves of both resistivity and conductivity (Keys, 1997). Conductivity is affected by the salinity of borehole and formation fluids and the type of lithology encountered. Generally, pure carbonates, sands, and gravels have lower conductivity (thus higher resistivity) than clays or shales (Keys, 1997).

\section{Surface Geophysics}

Surface geophysical resistivity methods can be used to detect changes in the electrical properties of the subsurface using noninvasive surface-based instrumentation (Zohdy and others, 1974). These methods are useful in order to fill data gaps in areas where borehole methods cannot be used. The electrical properties of soil and rock are determined by water content, porosity, clay content and mineralogy, and conductivity (or reciprocal of electrical resistivity) of the pore water (Lucius and others, 2007). Resistivity measurements can be used to construct graphical images of the spatial distribution of electrical properties of the subsurface. Comprehensive descriptions of the theory and application of surface geophysical resistivity methods, as well as tables of the electrical properties of earth materials, are presented in Keller and Frischknecht (1966) and Lucius and others (2007).

TDEM soundings were collected at four different locations (Pearson and others, 2012). Each of the locations was near a well where borehole geophysical logs also had been collected by the USGS. These locations were selected so that the TDEM results could be compared to the nearby borehole geophysical logs to determine if this geophysical method would supply useful data. Figure 5 shows an example comparison of a TDEM sounding and a nearby borehole geophysical log. The TDEM data collected throughout the area show good inversion results with the root mean squared (RMS) errors for all soundings less than 4 percent (Pearson and others, 2012), but few TDEM results were available at the depths needed to determine the tops and bases of formations.
Consequently, AMT was determined the better method to obtain information necessary to determine the tops and bases of formations.

Thirteen AMT soundings (AMT01 through AMT13) were collected in the study area (Pearson and others, 2012). Four of the 13 soundings were collected near wells (AMT $07,08,11,12$ ) from which borehole geophysical logs were collected by the USGS. These locations were selected so that the AMT soundings could be compared to the nearby borehole geophysical logs, which aided in the interpretation of the AMT soundings. Figure 6 shows an example comparison of an AMT sounding and a nearby borehole geophysical log. The remaining nine sounding locations (table 2) were selected where little or no other compiled data were available. An explanation of the processing and inversion methodologies performed on the TDEM and AMT data is provided by Pearson and others (2012).

\section{Hydrostratigraphic Unit Interpretation}

Lithologic descriptions and borehole geophysical logs obtained from existing reports were interpreted to identify the vertical extents (tops and bases, hereinafter referred to as picks) of hydrostratigraphic units. Once all of the existing data was compiled, a geospatial analysis was done to identify data gaps. Using picks from all the existing reports, the 44 additional borehole logs and 9 AMT soundings (fig. 7), threedimensional surfaces were interpolated to represent the tops and bases of applicable hydrostratigraphic units.

Hydrostratigraphic picks were made from stratigraphic and lithologic descriptions and were compiled from existing reports. Logs with information concerning the tops and bases of various geological stratigraphic units were selected from published reports and databases as the basis for subsequent hydrostratigraphic picks on geophysical logs (fig. 8) (Meyer and others, 2011; Herald, 1957). Multiple types of geophysical logs were compiled for each borehole geophysical site in the study area and evaluated for use; however, the majority of the logs that fit project requirements regarding the type of geophysical data and depth interval were natural gamma logs. Natural gamma logs were most useful, in part, because of their versatility; they are one of the few geophysical tools that can be run in steel casing, which is present in many wells in the area, and they typically provide a good indication of clay content.

Picks for the Edwards part of the Edwards-Trinity aquifer (Fredericksburg and Washita Groups) and the Trinity part of the Edwards-Trinity aquifer (Trinity Group) were made because, although they are both units of the same aquifer, they have different hydrologic and lithologic characteristics (table 1). In order to determine stratigraphic picks for the Trinity Group, surface geophysical inverse modeling results were interpreted with layered-earth electrical scenarios in which each layer represents a separate electrical layer (Pearson and others, 2012). These electrical layers were then associated with the stratigraphic layers, which in turn were used to 


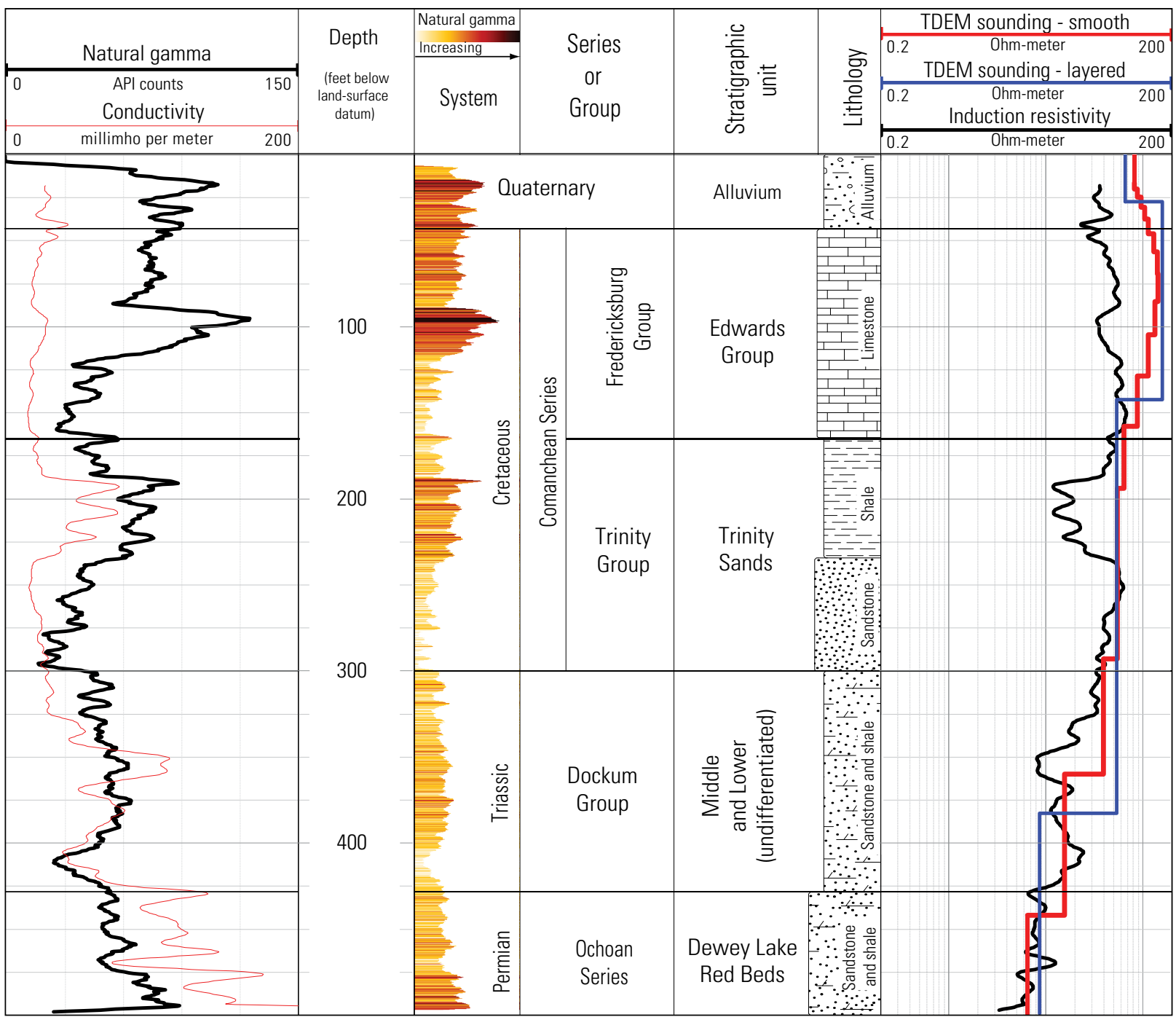

Note: Land surface datum, 3;238.70 feet above North American Vertical Datum 1988; API counts, American Petroleum Institute counts; TDEM Sounding, Time-domain electromagnetic sounding; TDEM Sounding - Smooth, smoothed inverse resistivity modeling results; TDEM Sounding - Layered, layered-earth resistivity modeling scenario

Figure 5. Example log for well 304711103003301 showing natural gamma, and induction conductivity/resistivity borehole geophysical properties, time-domain electromagnetic (TDEM) soundings, and stratigraphic layers for the Pecos County region study area, Texas.

identify water-bearing hydrogeologic units. For the TDEM inverse modeling results, a layered-earth resistivity model was created where this model was used as the layered-earth electrical scenarios (Pearson and others, 2012). Because the AMT inverse modeling software does not iterate a layeredearth resistivity model, another method to obtain the layeredearth electrical scenarios was developed. The layered-earth electrical scenarios for the AMT soundings were interpreted based on electrical changes in the smooth inverse modeling results (fig. 9). The resistivity values of these layers were selected at peak points along the smooth inverse modeling results, and the corresponding resistivity value was assigned to that layer. The top and bottom depths of each layer were interpreted by making the difference of the areas between the layered-earth electrical scenario layer and the smooth inverse modeling results directly above and below the depth pick equal to zero. Most of the AMT soundings were laterally anisotropic at the sounding location. For these soundings, a resistivity curve was made for the magnetic response (TM), the electrical response (TE), and a combination of the two responses (TMTE). Each of the three responses was interpreted individually to develop three layered-earth electrical scenarios followed by an average layered-earth electrical scenario. For the soundings that had little or no lateral variation in the subsurface, the TMTE response was calculated and interpreted. One disadvantage of surface geophysical techniques is the vertical resolution decreases with depth. The accuracy of the picks made from the surface geophysical methods was considered to be about plus or minus 10 percent of the depth. 


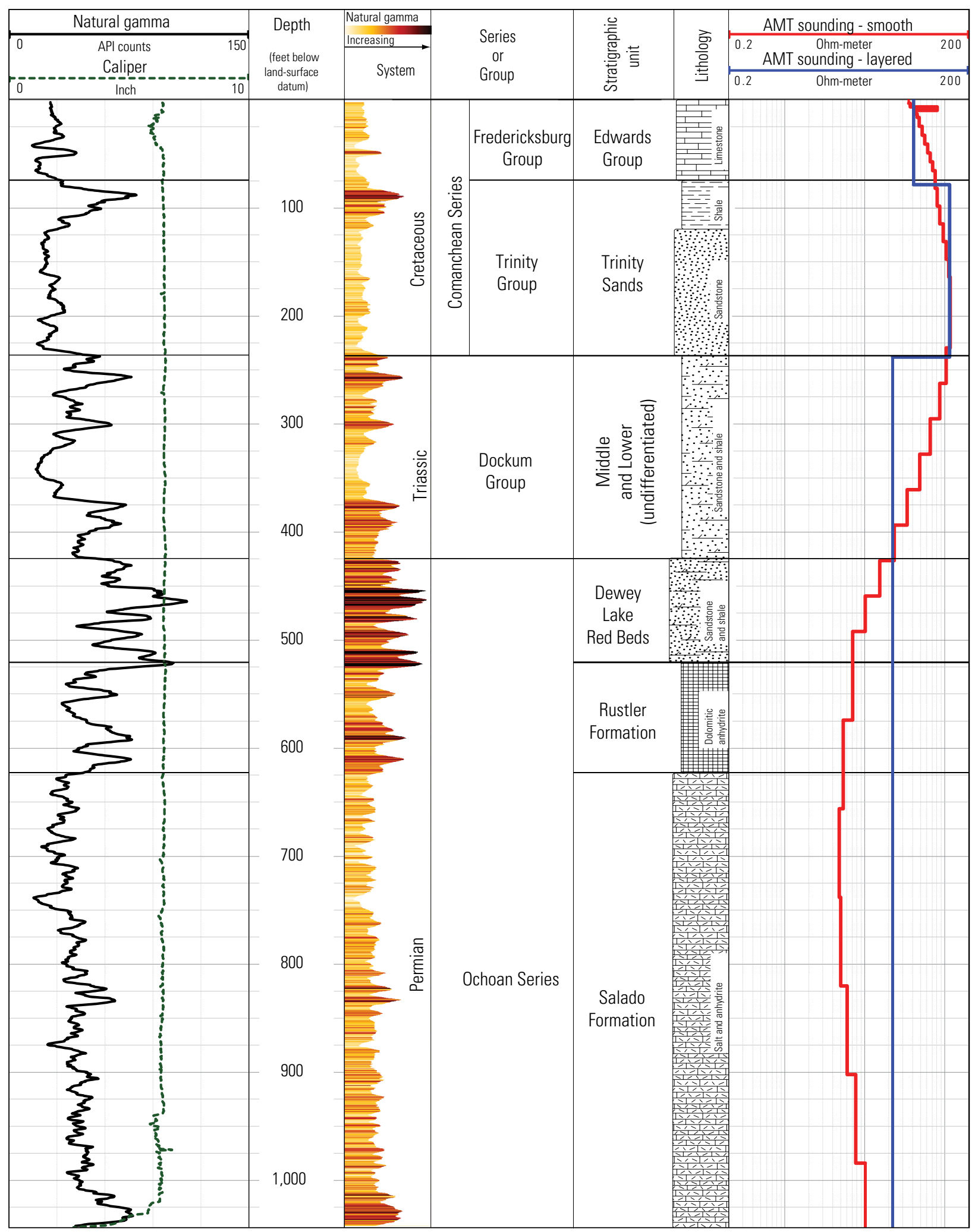

Note: land surface datum, 4;354.39 feet above North American Vertical Datum of 1988; API Counts, American Petroleum Institute counts; AMT Sounding, audio-magnetotelluric sounding; AMT Sounding - Smooth, smoothed inverse resistivity modeling results; AMT Sounding - Layered, layered-earth resistivity modeling scenario

Figure 6. Example log for well 302630102503801 showing natural gamma borehole geophysical properties, audio-magnetotelluric sounding (AMT08), and stratigraphic layers in the Pecos County region study area, Texas. 


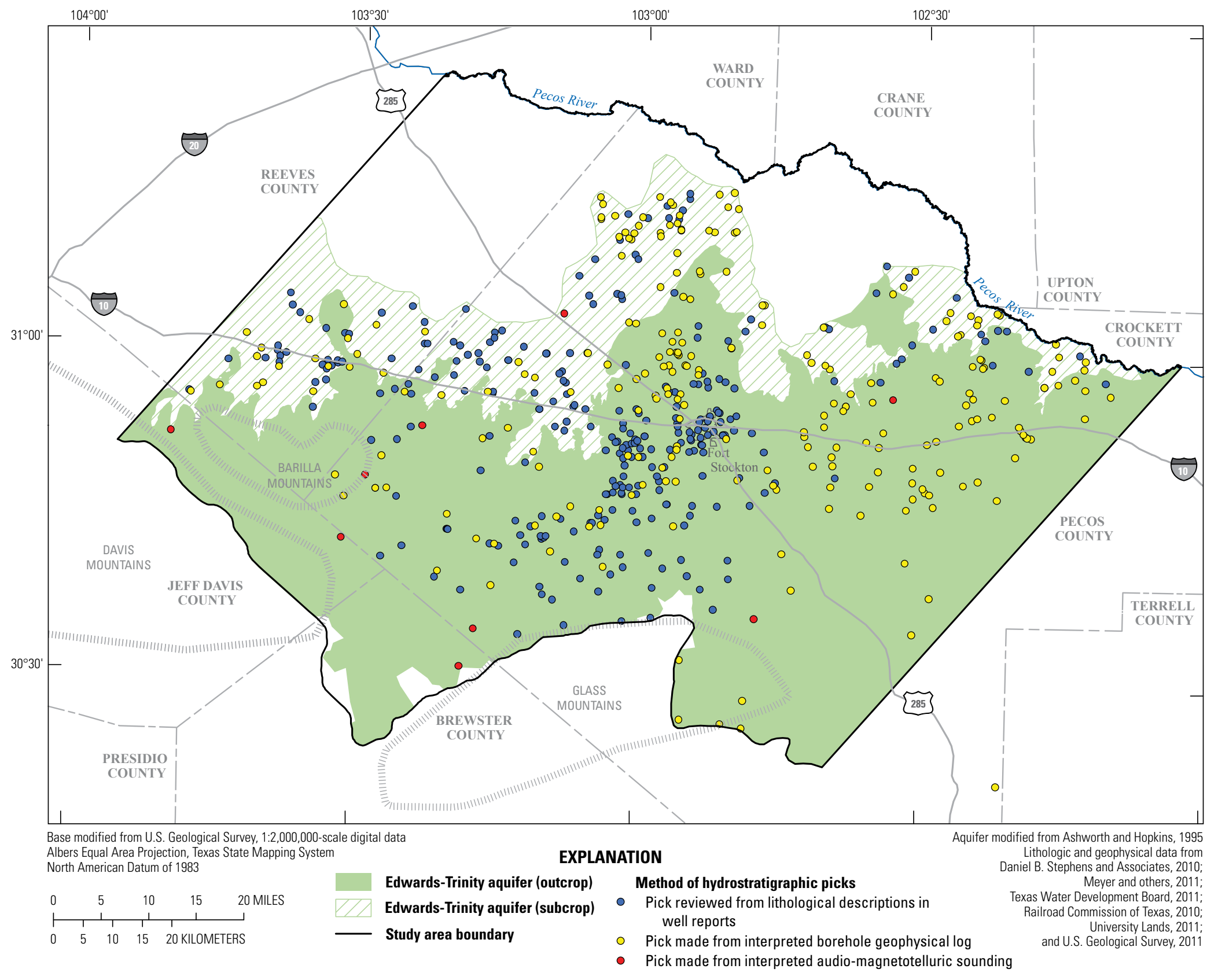

Figure 7. Locations where geological and geophysical data were used to determine the tops and bases (picks) of hydrostratigraphic subdivisions in the Pecos County region study area, Texas. 
$\boldsymbol{A}$

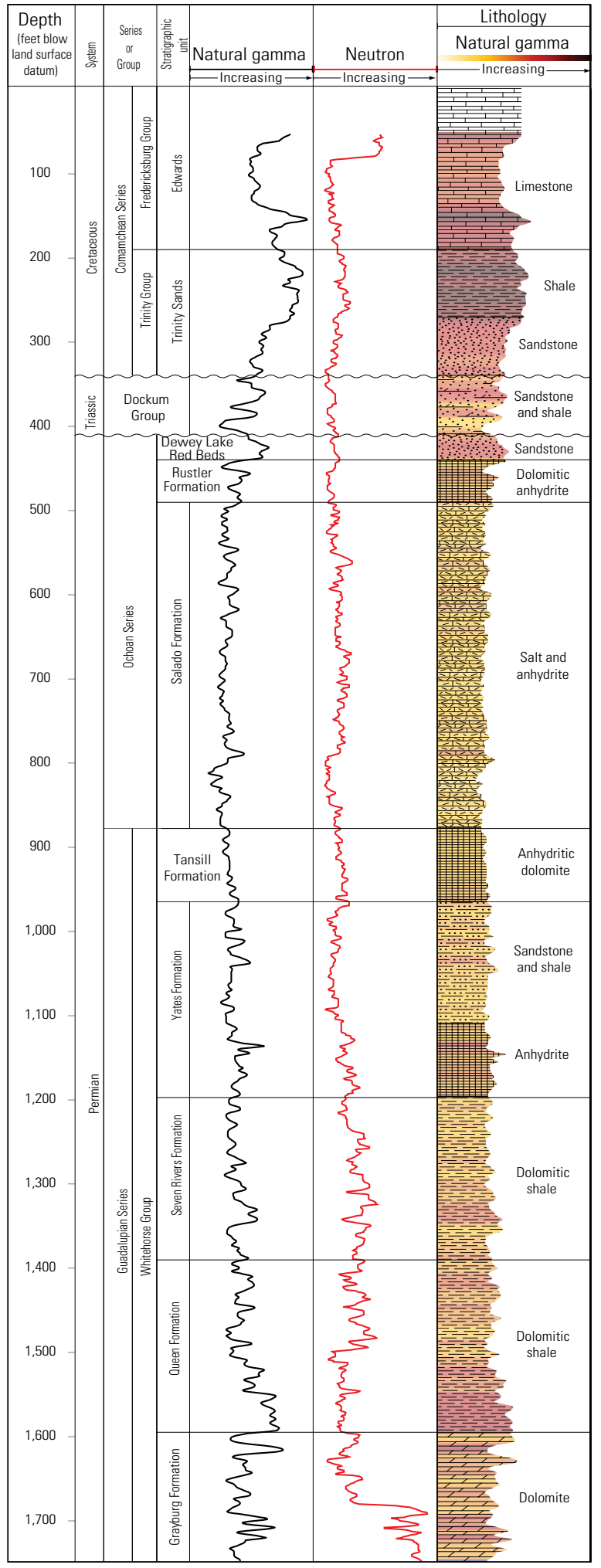

Note: land surface datum; North American Vertical Datum 1988
$B$

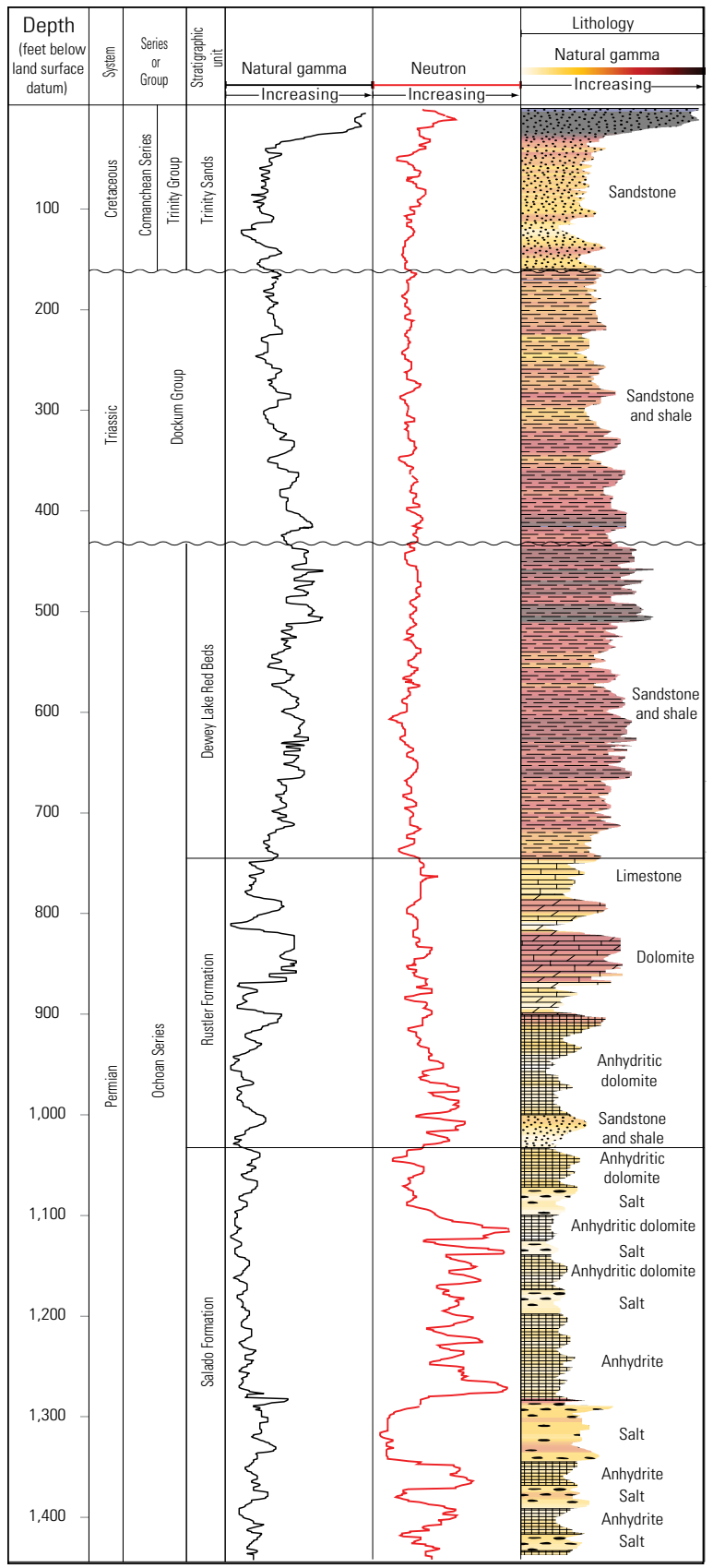

Figure 8. Example logs with geophysical properties of Permian, Triassic, and Cretaceous-age stratigraphic layers in $A$, northern Pecos County and $B$, northwestern Pecos County in the Pecos County region study area, Texas (modified from Herald, 1957). 


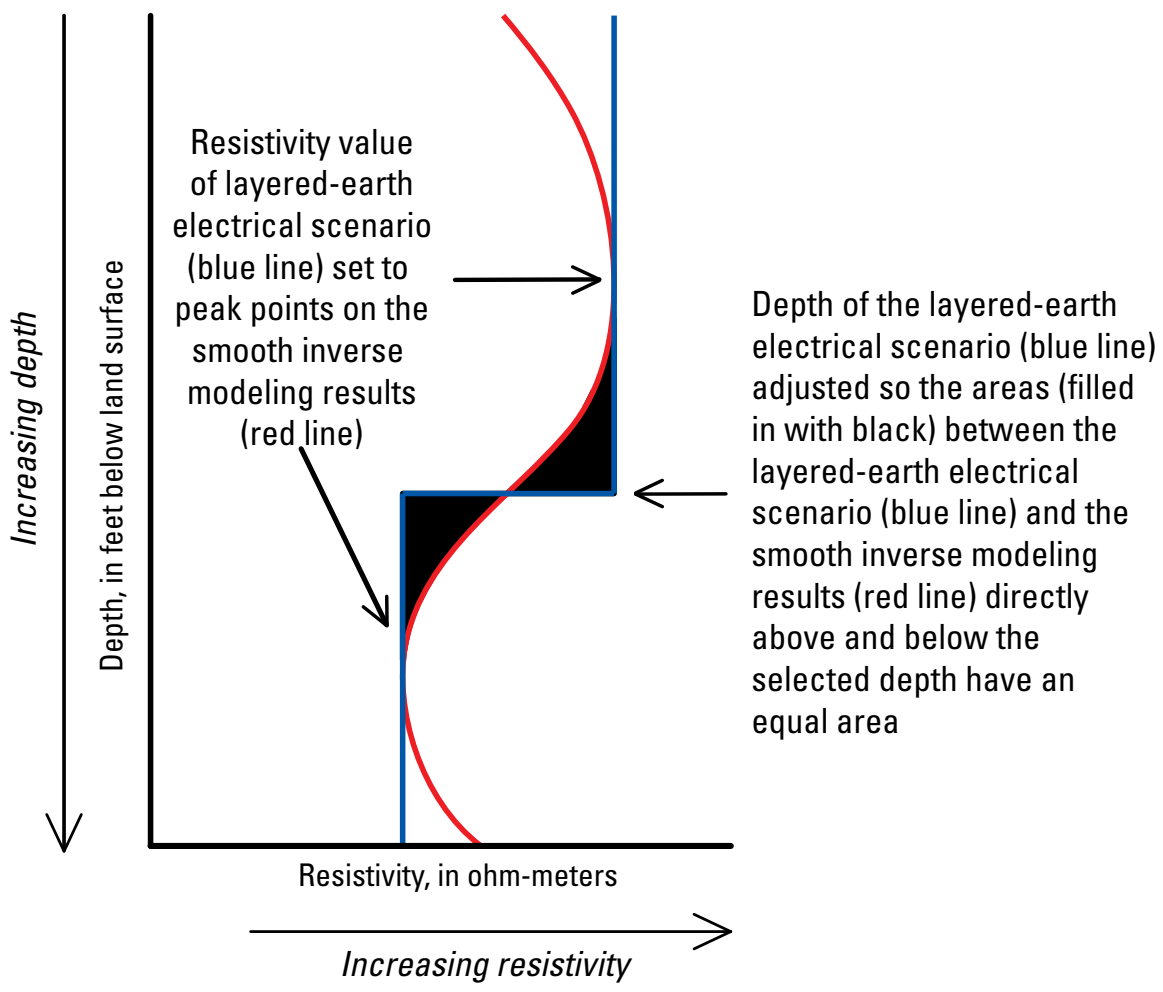

Figure 9. Schematic showing the procedure to develop layered-earth electrical scenarios for the audio-magnetotelluric smooth inverse modeling results for the Pecos County region study area, Texas.

The layered-earth electrical scenarios obtained for applicable AMT soundings were compared to nearby well data in order to interpret the electrical signature of the Trinity Group compared to the borehole geophysical log picks (fig. 7, table 3 at end of report). Based on the AMT-log comparison, the Trinity Group was determined to be moderately resistive (approximately $50 \mathrm{ohm}$-meters) and was generally the first resistive layer below the first conductive layer. This information was used to interpret the depth of the Trinity Group in the nine AMT soundings that were not near a well.

The layered-earth electrical scenarios for the four AMT soundings near wells (AMT07, AMT08, AMT11, and AMT12) resulted in the identification of different electrical layers. Each layer was identified as electrically conductive (referred to as a conductor) or electrically resistive (referred to as a resistor). Four scenarios of conductors and resistors were identified. The scenarios from AMT07 and AMT08 were similar with three (AMT07) or four layers (AMT08) identified; for both soundings, the four layers (in top-down order from the surface) were sequentially conductor, resistor, conductor, and resistor (fig. 10a). The second scenario (AMT12) consisted of five layers with a near-surface resistor followed by a conductor, which was followed by three layers progressively becoming more resistive (fig. 10b). The last scenario (AMT11) consisted of five or six layers with alternating conductive and resistive layers where the five-layer scenario had a resistor at surface and the six-layer scenario had a conductor at surface (fig. 10c). Three of the four soundings (AMT07, AMT08, and AMT11) resulted in layers that matched closely (within the accuracy of AMT measurements; Pearson and others, 2012) to the picks made from the borehole geophysical logs. The one exception was the pick for the bottom of the Trinity Group at AMT08 which was substantially lower (greater than 150 $\mathrm{ft}$ lower or 50 percent of the AMT depth pick) than the pick made from the borehole geophysical log. The fourth sounding (AMT12) did not resolve the Trinity Group likely because the unit was too thin to identify.

The layered-earth electrical scenarios for the remaining nine AMT soundings consisted of similar scenarios as the AMT soundings located near the wells. These scenarios are grouped into three pairs of scenarios. The first pair of scenarios, which was equivalent to the layer-earth electrical scenarios found at AMT07 and AMT08 (fig. 10a), had three (AMT06) and four layers (AMT13); in top-down order from the surface, conductor, resistor, and conductor electrical layers were identified with an additional resistor below the bottom conductor in the fourth layer. The second pair of scenarios, which was equivalent to the layered-earth electrical scenario found at AMT12 (fig. 10b), consisted of four (AMT10) or five layers (AMT04 and AMT05) with a near-surface resistor 
A

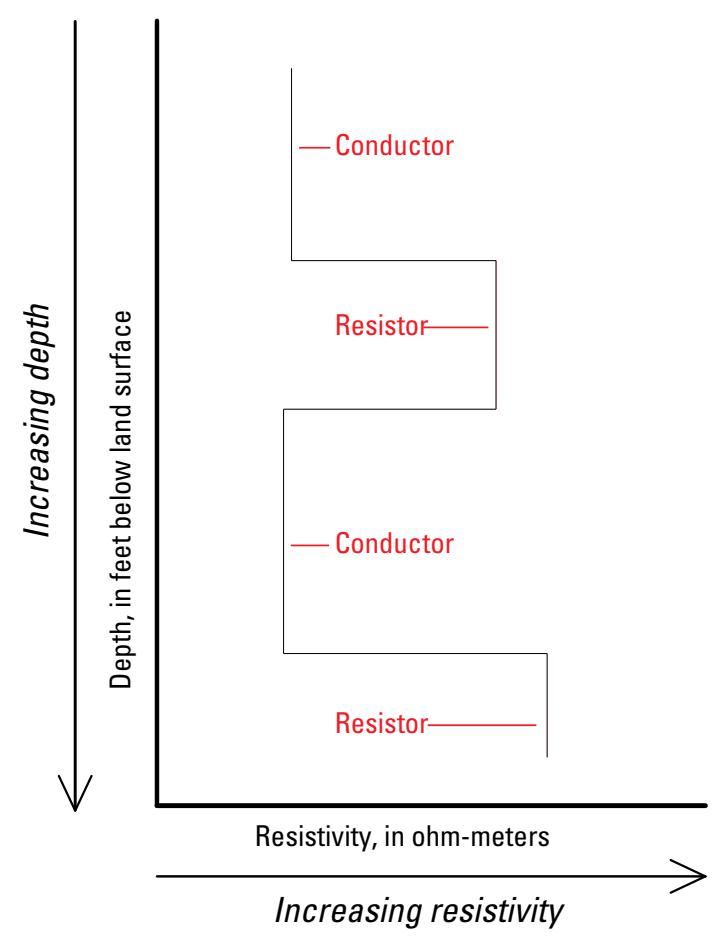

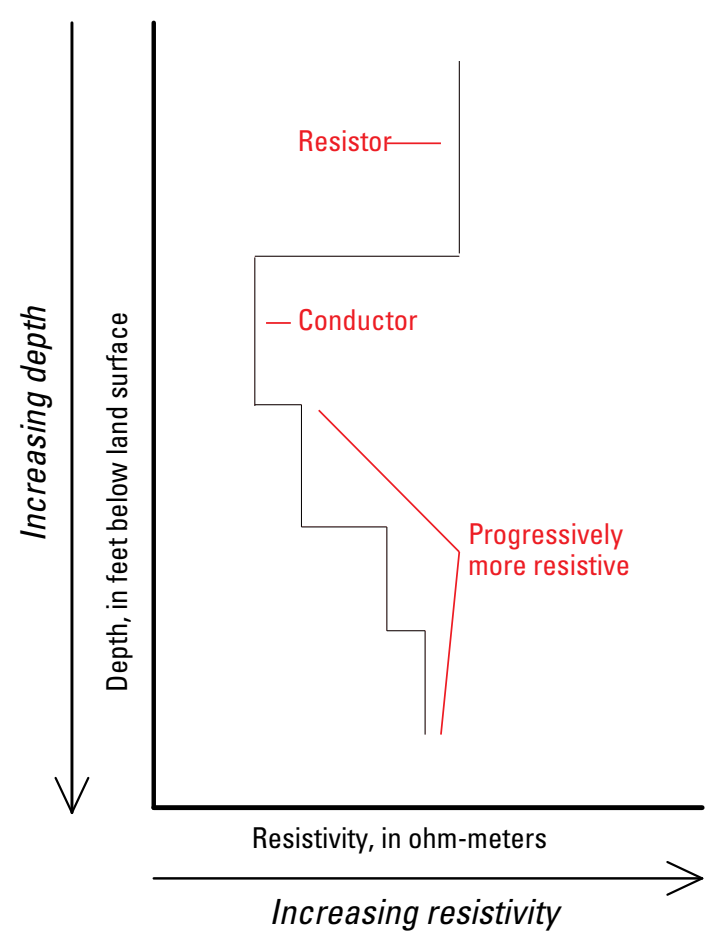

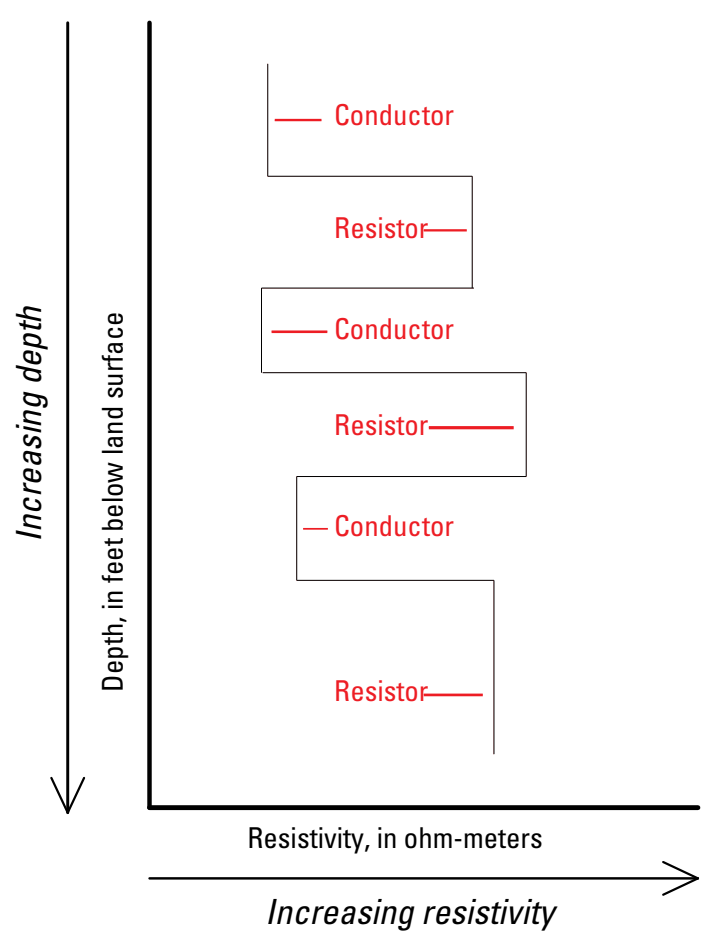

Figure 10. Schematic diagram of three $(A, B$, and $C)$ layered-earth electrical scenarios for the Pecos County region study area, Texas. 
followed by a conductor, which was followed by two or three layers progressively becoming more resistive. The pair of scenarios, which was equivalent to the layered-earth electrical scenario found at AMT11, had five or six alternating resistive and conductive layers; the five-layer scenario had a resistor at surface (AMT01, AMT03, and AMT09) and the six-layer scenario had a conductor at surface (AMT02).

The general electrical responses of the Trinity Group were interpreted using the picks made from the borehole geophysical logs and comparing those depths with the picks made from the AMT soundings. The Trinity Group was moderately resistive (between 15-160 ohm-meters) with a calculated log-mean of $50 \mathrm{ohm}$-meters. The most resistive part of the Trinity Group layer was found in the southeastern part of the study area, and the least resistive part of the Trinity Group layer was found near the northern edge of the study area. Because borehole geophysical logs provided high vertical resolution in the subsurface, the picks made from the borehole geophysical logs were preferentially chosen as the final picks over nearby TDEM and AMT soundings.

After the geophysical logs and soundings were compiled and interpreted and hydrostratigraphic picks were determined, grids were created for each surface using kriging interpolation techniques. Geosoft, Inc. (2012) contains a complete description of the kriging methods used for grid interpolation. Preliminary grids were used to identify outliers and areas requiring review. To aid in identifying outliers, the residual was calculated as the difference between the hydrostratigraphic pick at each geophysical log or AMT sounding to the interpolated grid value. All locations with a residual greater than an absolute value of $15 \mathrm{ft}$ were evaluated through a correlation process to determine data-point uncertainty. The correlation process involved the comparison of the pick at a given site to the picks made at nearby sites to determine if it "correlated" with the nearby well picks. If the pick varied by more than $15 \mathrm{ft}$ from the nearby picks and seemed to not coincide with overall hydrostratigraphy of the area, it was removed from the final grid. Throughout the process, all stratigraphic picks were reviewed and revised as needed to provide a better understanding of the stratigraphic unit.

\section{Structural Interpretations}

Changes in altitude of the tops and bases of aquifer units, unit thicknesses, and normal-fault zones of the EdwardsTrinity aquifer were interpreted using the surfaces created from the interpolation of the hydrostratigraphic picks. Fault zones were delineated based on the interpretation of cross sections of the interpolated top and base surfaces of the Edwards-Trinity aquifer units and are similar to faults delineated previously for the underlying Rustler aquifer (INTERRA Incorporated, 2011). Displacement along fault zones is included in the final interpretation of the tops, bases, and thicknesses of the aquifer units.
Changes in altitude of the top of the Edwards-Trinity aquifer, which is, in general, the top of the Edwards part of the aquifer (upper Cretaceous), closely matched those of the land-surface altitudes throughout most of the study area. The altitude of the top surface of the Edwards-Trinity aquifer was highest in the southern part of the study area near the Glass Mountains (about 4,315 ft; fig. 11). For comparison purposes, the altitude ramps in figures 11,12 , and 13 are the same and include the minimum altitude in the base surface of the Edwards-Trinity aquifer and the maximum altitude in the top surface of the Edwards-Trinity aquifer. The altitude decreased to the northeast and the lowest altitude near the northeastern edge of the study area at the Pecos River was about 2,250 ft. The Edwards-Trinity aquifer dipped more sharply than the slope of the land surface in two locations. The first location was near the north-central boundary of the study area in the Monument Draw trough (fig. 2) where the altitude of the top of the Edwards-Trinity aquifer drops to about 2,020 ft, which was the lowest interpolated altitude for the top of the EdwardsTrinity aquifer. The other location where the altitude of the top of the Edwards-Trinity aquifer dropped substantially was in the northwestern part of the study area in the Pecos trough (fig. 2) where the altitude was about $2,450 \mathrm{ft}$.

Changes in altitude of the top of the Trinity Group (fig. 12) closely matched those of the top of the EdwardsTrinity aquifer (fig. 11) in most of the study area. The altitude of the top surface of the Trinity Group was highest in the southern part of the study area near the Glass Mountains (about 4,230 ft; fig. 12). The altitude decreased to the northeast similar to the top of the Edwards-Trinity aquifer and the lowest altitude near the northeastern edge of the study area at the Pecos River was about 2,250 ft. The lowest altitude of the top of the Trinity Group was near the north-central boundary of the study area in the Monument Draw trough (fig. 2) where the altitude was about $1,960 \mathrm{ft}$.

The base surface of the Edwards-Trinity aquifer (fig. 13) had similar spatial trends as the top of the Trinity Group (fig. 12) and the top of the Edwards-Trinity aquifer (fig. 11). The highest altitude of the base of the Edwards-Trinity aquifer was in the southern part of the study area near the Glass Mountains (about 4,110 ft). Similar to the top of the Trinity Group of the Edwards-Trinity aquifer, the altitude of the base of the Trinity Group decreased to the northeast, which is consistent with findings by Barker and Ardis (1992). The lowest altitude for the base of the Edwards-Trinity aquifer (about 1,555 ft) was in the north-central part of the study area in the Monument Draw trough (fig. 2).

The thickness of the Edwards-Trinity aquifer in the study area was calculated as the difference in altitudes between its top and base (fig. 14). About 50 percent of the aquifer was between 234 and $362 \mathrm{ft}$ thick, about 25 percent was less than $234 \mathrm{ft}$ thick, and about 25 percent was more than $362 \mathrm{ft}$ thick. The minimum thickness was $5 \mathrm{ft}$ and the maximum thickness was about $797 \mathrm{ft}$. The thickness of the Edwards part of the aquifer in the study area was calculated as the difference in 


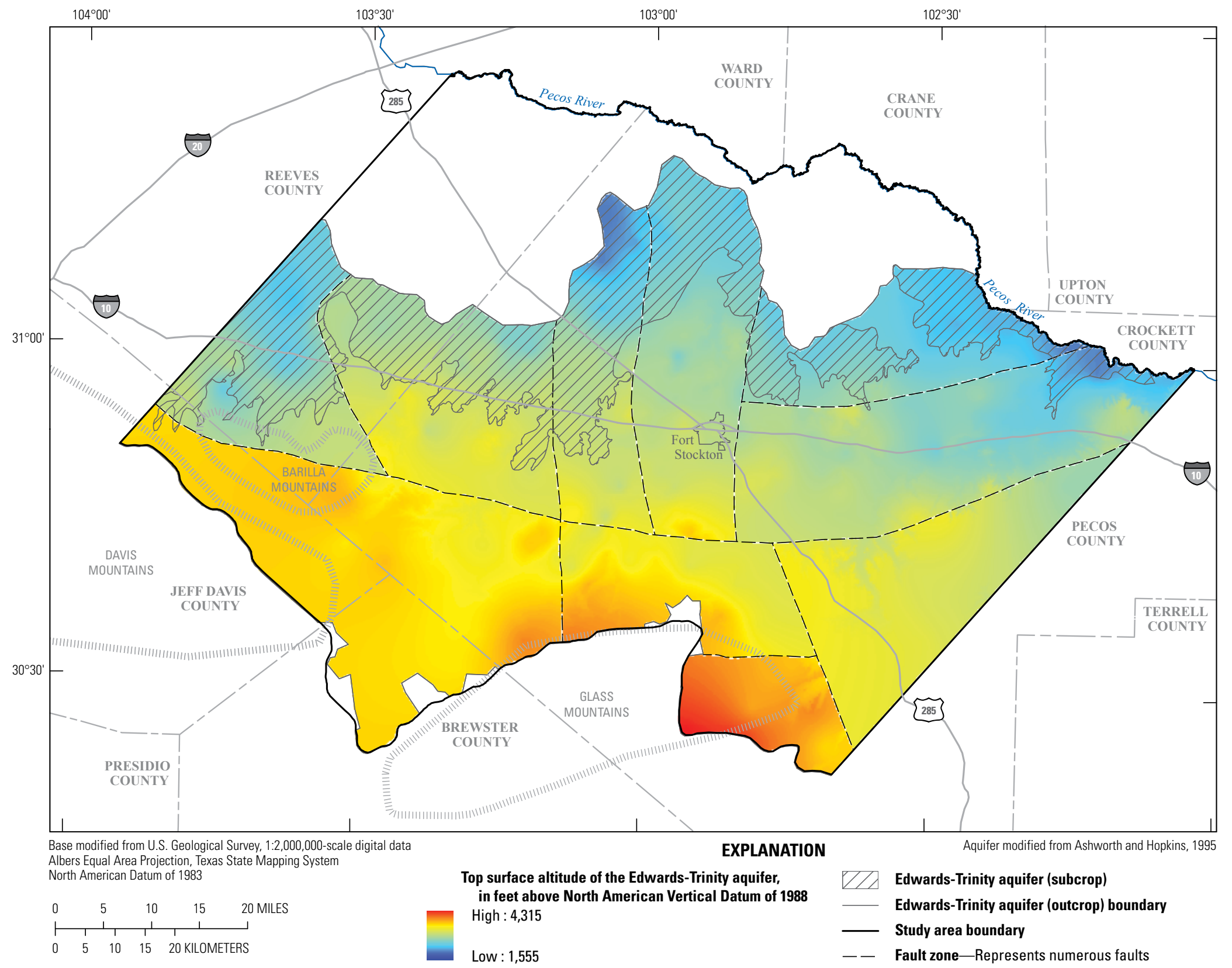

Note: For comparison purposes, the altitude ramps in figures 11,12 , and 13 are the same and include the minimum altitude in the base surface of the Edwards-Trinity aquifer and the maximum altitude in the top surface of the Edwards-Trinity aquife

Figure 11. The altitude of the top surface of the Edwards-Trinity aquifer estimated by interpolating the tops and bases of hydrostratigraphic subdivisions in the Pecos County region study area, Texas. 


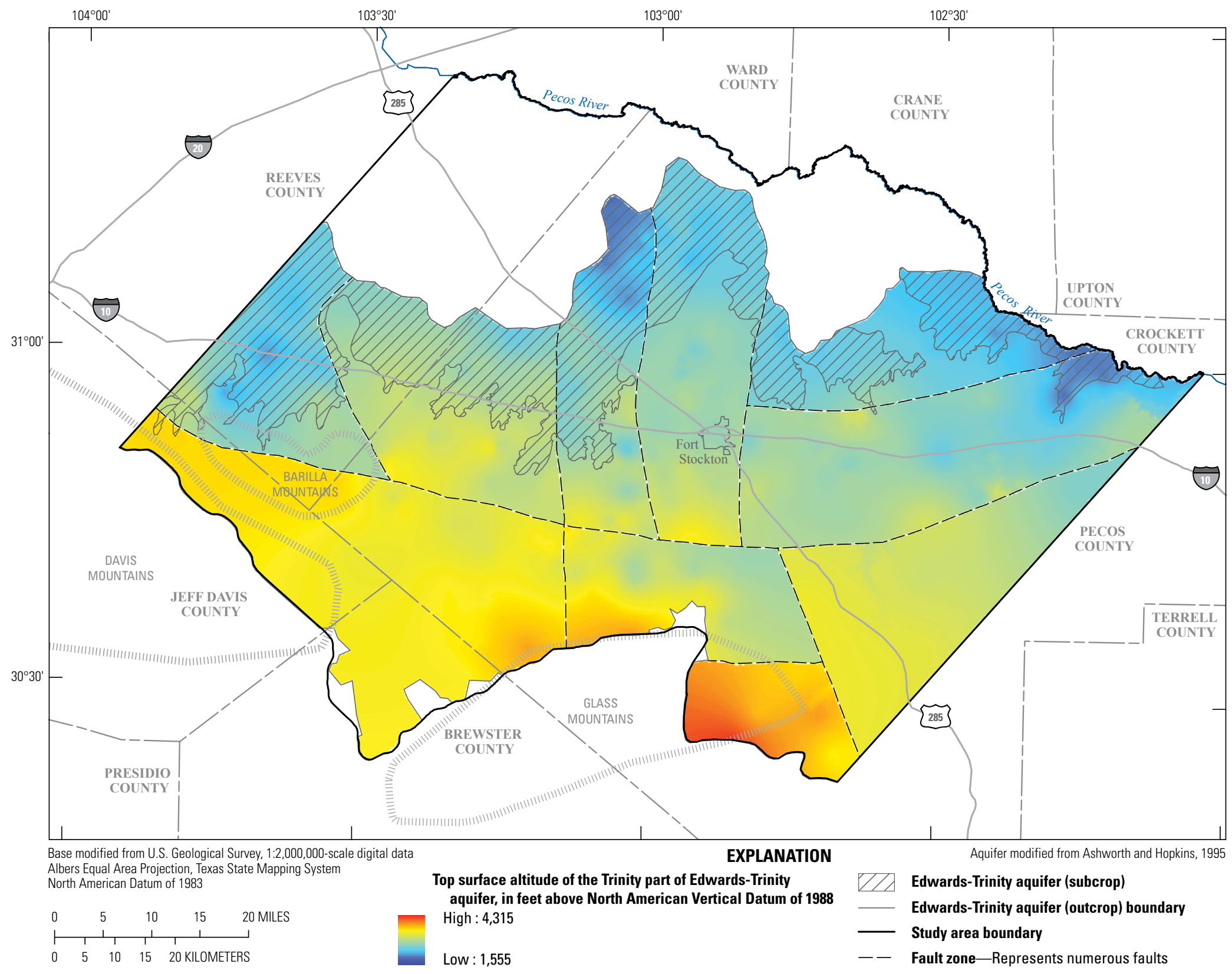

Note: For comparison purposes, the altitude ramps in figures 11,12 , and 13 are the same and include the minimum altitude in the base surface of the Edwards-Trinity aquifer and the maximum altitude in the top surface of the Edwards-Trinity aquifer.

Figure 12. The altitude of the top surface of the Trinity part of the Edwards-Trinity aquifer estimated by interpolating the tops and bases of hydrostratigraphic subdivisions in the Pecos County region study area, Texas. 


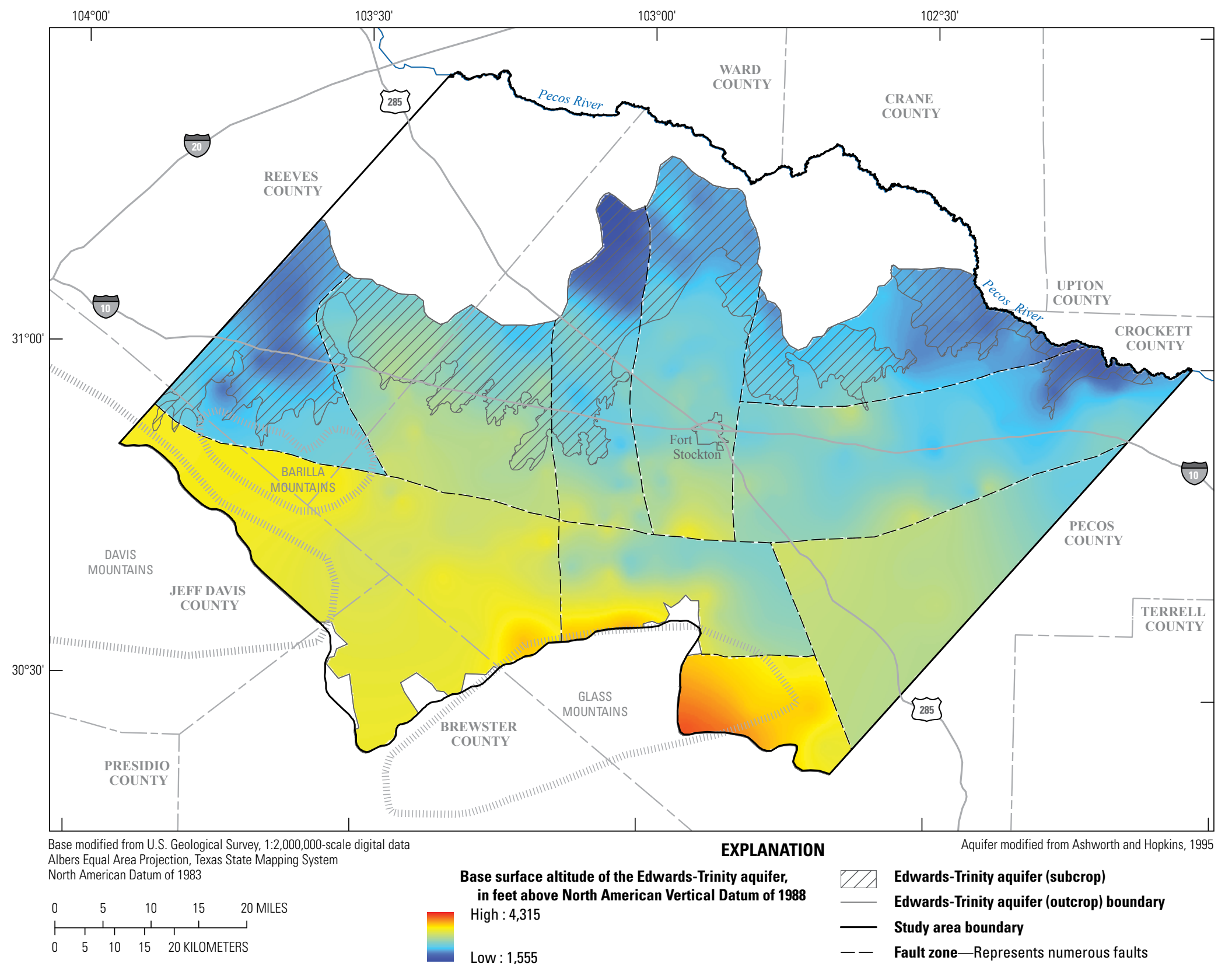

Note: For comparison purposes, the altitude ramps in figures 11, 12, and 13 are the same and include the minimum altitude in the base surface of the Edwards-Trinity aquifer and the maximum altitude in the top surface of the Edwards-Trinity aquifer

Figure 13. The altitude of the base surface of the Edwards-Trinity aquifer estimated by interpolating the tops and bases of hydrostratigraphic subdivisions in the Pecos County region study area, Texas. 
altitudes between the top of the Edwards-Trinity aquifer and the top of the Trinity Group (fig. 15). About 50 percent of the Edwards part of the aquifer was between 44 and $169 \mathrm{ft}$ thick, about 25 percent was less than $44 \mathrm{ft}$ thick, and about 25 percent was more than $169 \mathrm{ft}$ thick. The minimum thickness was $0 \mathrm{ft}$ and the maximum thickness was about $723 \mathrm{ft}$. The thickness of the Trinity Group in the study area was calculated as the difference in altitudes between the top of the Trinity Group and the bottom of the Edwards-Trinity aquifer (fig. 16). About 50 percent of the Trinity Group was between 144 and $224 \mathrm{ft}$ thick, about 25 percent was less than $144 \mathrm{ft}$ thick, and about 25 percent was more than $224 \mathrm{ft}$ thick. The minimum thickness was $3 \mathrm{ft}$ and the maximum thickness was about $543 \mathrm{ft}$.

Some of the thinnest sections of the Edwards-Trinity aquifer were in the eastern part of the study area, near the northwestern slope of the Glass Mountains, and near the northeastern slope of the Davis Mountains. It was determined that the aquifer was often thickest in the central part of the study area in the Monument Draw trough and at the western edge of the study area in the Pecos trough, which is consistent with findings by Barker and Ardis (1992). There were three areas of the Edwards-Trinity aquifer where substantial thickness variations were identified; in two areas, the thickness of the aquifer increased appreciably per unit of horizontal length (fig. 14). In the areas west of Fort Stockton and north of the Glass Mountains, the base of the Edwards-Trinity aquifer dips at a higher angle to the north than does the top of the Edwards-Trinity aquifer. In the third location, a valley exists in the top of the Edwards-Trinity aquifer between the Glass Mountains and the Davis Mountains that did not appear in the base of the Edwards-Trinity aquifer, which resulted in a thinner section of the aquifer.

Some of the thinnest sections of the Edwards part of the aquifer (fig. 15) were in the eastern part of the study area, near the northwestern slope of the Glass Mountains, and in the down-dip part of the Pecos trough (fig. 2). Based on interpretation of the data, it is likely that many of the thinnest sections of the Edwards part of the aquifer are associated with active or paleo-erosional features. Some of the thickest sections of the Edwards part of the aquifer were generally in the southern and central parts of the study area in the Monument Draw trough (fig. 2).

Some of the thinnest sections of the Trinity Group of the Edwards-Trinity aquifer were in the eastern part of the study area and in the ridge that separates the Pecos and Monument Draw troughs (fig. 2). Some of the thickest sections of the Trinity Group were in the western part of the study area in the Pecos trough and in the central part of the study area in the Monument Draw trough.

Faults in the study area likely formed as growth and collapse features as sediments were deposited along the margins of more resistant rocks and structures, such as the Glass Mountains, and as sediments collapsed into the voids created by the dissolution of Permian-age evaporite deposits. Figures 17 and 18 show examples of the roughly west-east
$\left(\mathrm{A}-\mathrm{A}^{\prime}\right)$ and south-north $\left(\mathrm{B}-\mathrm{B}^{\prime}\right)$ orientated cross sections that were used to delineate the fault zones. The dips of these fault zones were not evaluated for this study. Also, although the Cretaceous (Edwards-Trinity) and Triassic (Dockum and underlying units) aquifers are shown in figures 17 and 18, the actual thicknesses of the Triassic units were not estimated for this study and are shown for reference only. Each fault zone represents a series of parallel and transverse faults that result in an overall displacement between two adjacent fault blocks. Fault zones (figs. 11-18) delineate domains in the hydrogeologic framework that generally align with previously identified structural features such as the Pecos and Monument Draw troughs (fig. 2). Some fault blocks, which are fault-bounded areas, shown in the cross sections (figs. 17 and 18), particularly those in the Pecos and Monument Draw trough areas, are not represented in the surface fault-zone delineations (figs. 17-18) because of the coarse resolution of the surface delineation. Also, there is likely extensive faulting at a relatively higher resolution not shown in each of the fault blocks in the cross sections.

The displacement along the delineated fault zones was calculated as the average displacement of combined faults within a given delineated fault block (figs. 11-16). For example, the displacement of the graben (an elongate trough or basin bounded by high-angle normal faults that dip toward one another [Neuendorf and others, 2005, p. 277]) that contains the Monument Draw trough (FB03) in cross section A-A' (fig. 17) relative to the adjacent horst (an elongate block bounded by normal faults that dip away from one another [Neuendorf and others, 2005, p. 307]) that includes deposits (FB04; fig. 17) that approximately overly the Capitan Reef aquifer (fig. 4) was calculated as the difference between the average basal altitudes of the two fault blocks in the graben and the average basal altitudes of the two fault blocks in the horst. Displacement along the trend of a fault zone varied depending on the basal altitudes of the adjacent fault blocks at a given location. The maximum interpreted displacement at a location along a delineated fault zone was about $1,025 \mathrm{ft}$ and is located along the FB01 and FB07 fault zone (figs. 17 and 18) in the Barilla Mountains (fig. 2). The minimum interpreted displacement at a location along a delineated fault zone was about $1 \mathrm{ft}$ and is located along the FB03 and FB04 fault zone (figs. 17 and 18) near Belding, Tex. (fig. 1).

Cross section $\mathrm{A}-\mathrm{A}^{\prime}$ originates at the western boundary of the study area in the Pecos trough (fig. 2) and extends to the eastern boundary of the study area (fig. 17). This section shows 11 horizontal horst, graben, and stairstep fault blocks (faults expressed as numerous small fractures, breccia, or fault gouges [Neuendorf and others, 2005, p. 231]). Each of these fault blocks likely contains a series of faults that result in a cumulative displacement along the fault zones. The Pecos trough (fig. 2) near the western boundary is in a graben (FB01; fig. 17) created by the dissolution of Permian-age evaporite deposits and the subsequent collapse of overlying units. It is possible that Edwards-Trinity units are not connected between fault blocks within the Pecos trough and, thus, create a barrier 


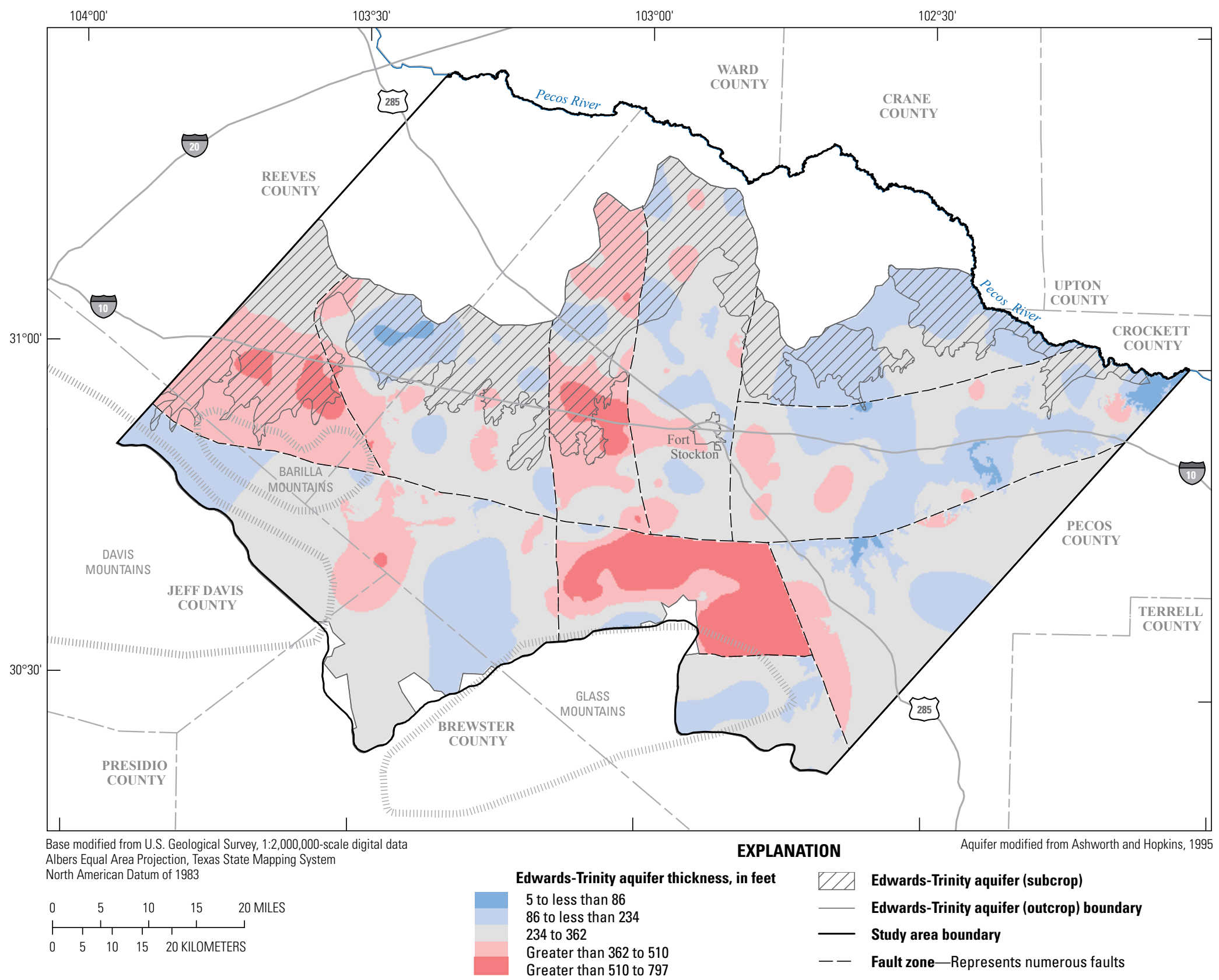

Figure 14. The thickness of the Edwards-Trinity aquifer in the Pecos County region study area, Texas, calculated as the difference between the altitudes of the top and base surfaces of the Edwards-Trinity aquifer. 


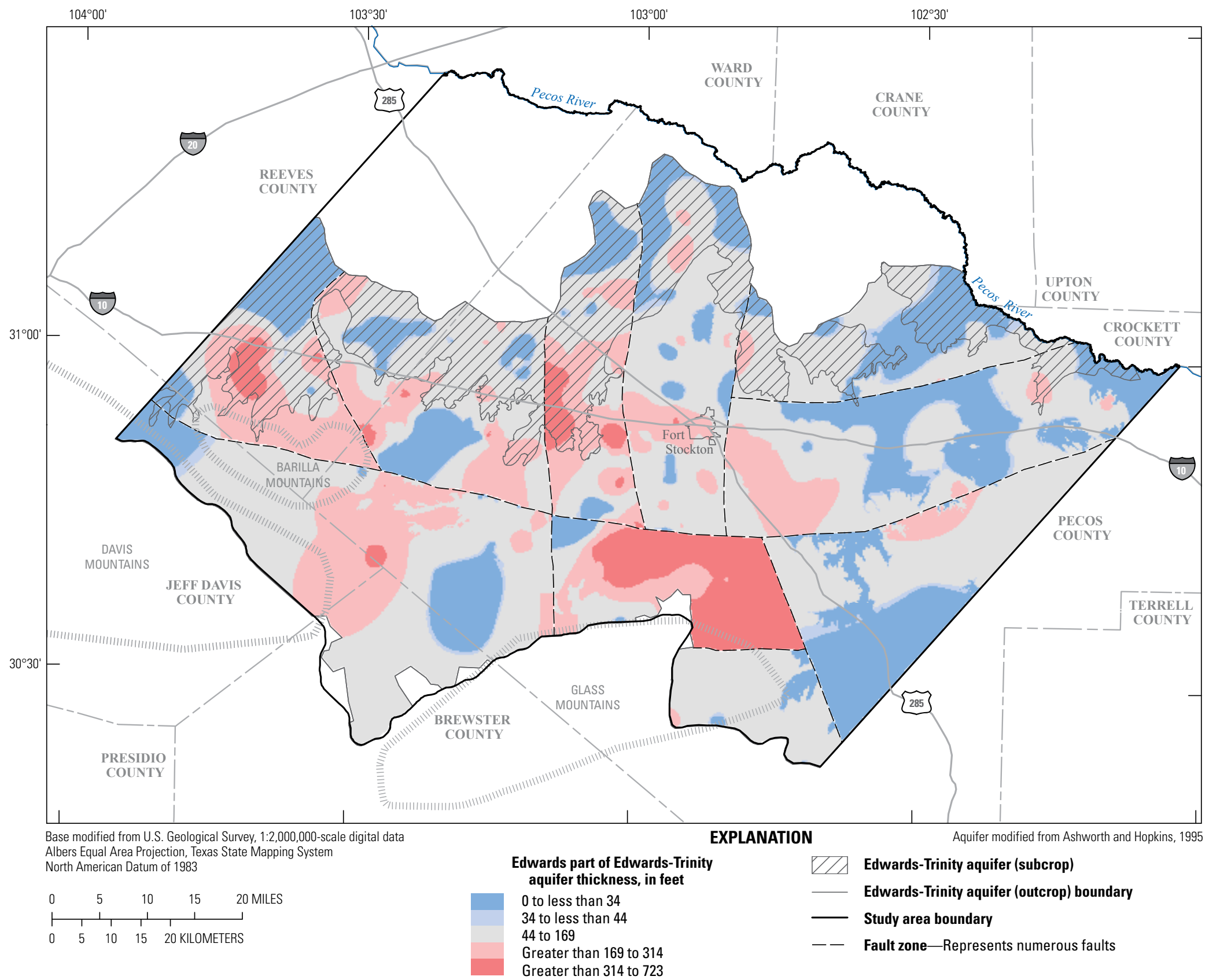

Figure 15. The thickness of the Edwards part of the Edwards-Trinity aquifer in the Pecos County region study area, Texas, calculated as the difference between the altitudes of the top and base surfaces of the Edwards part of the Edwards-Trinity aquifer. 


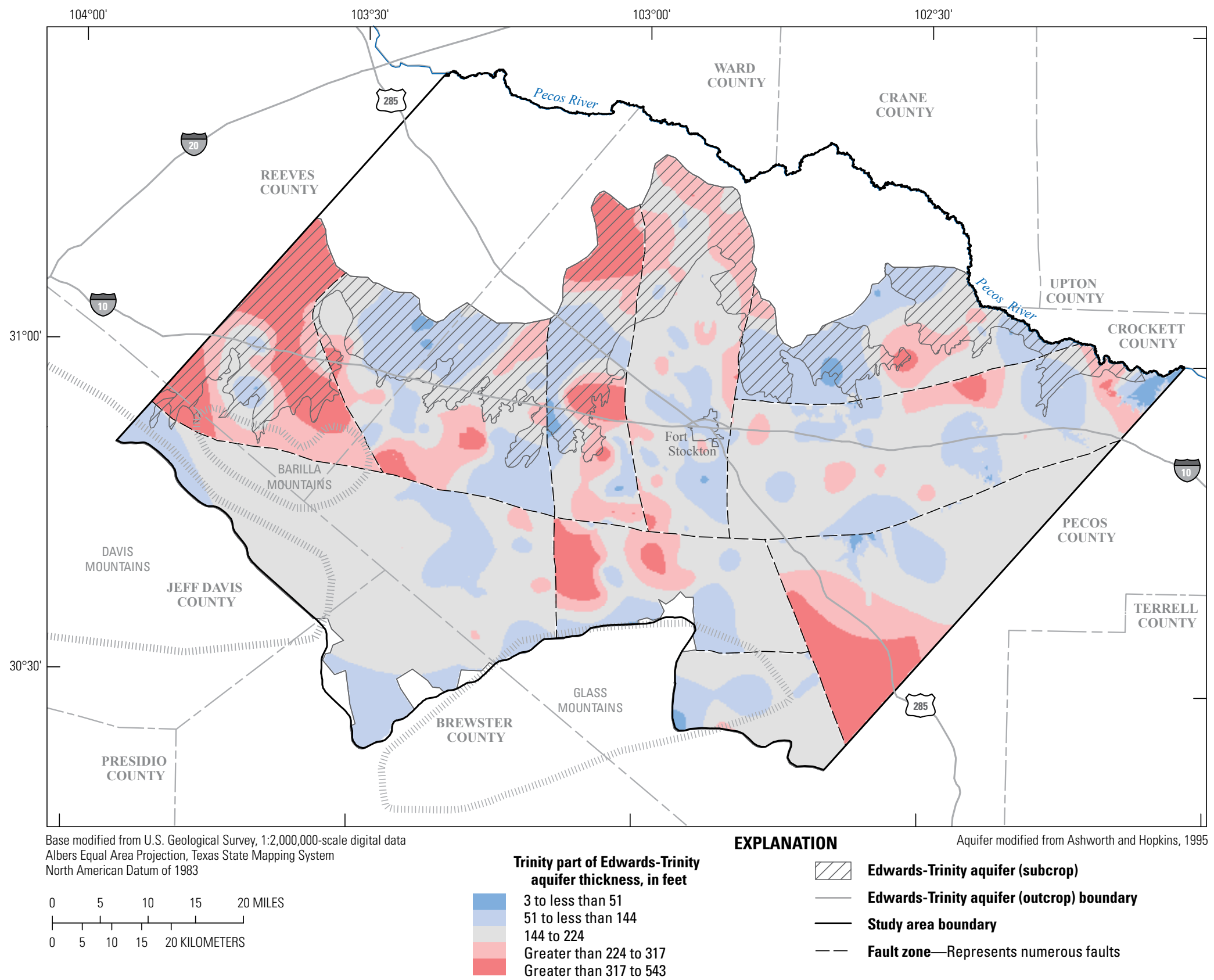

Figure 16. The thickness of the Trinity part of the Edwards-Trinity aquifer in the Pecos County region study area, Texas, calculated as the difference between the altitudes of the top and base surfaces of the Trinity part of the Edwards-Trinity aquifer. 

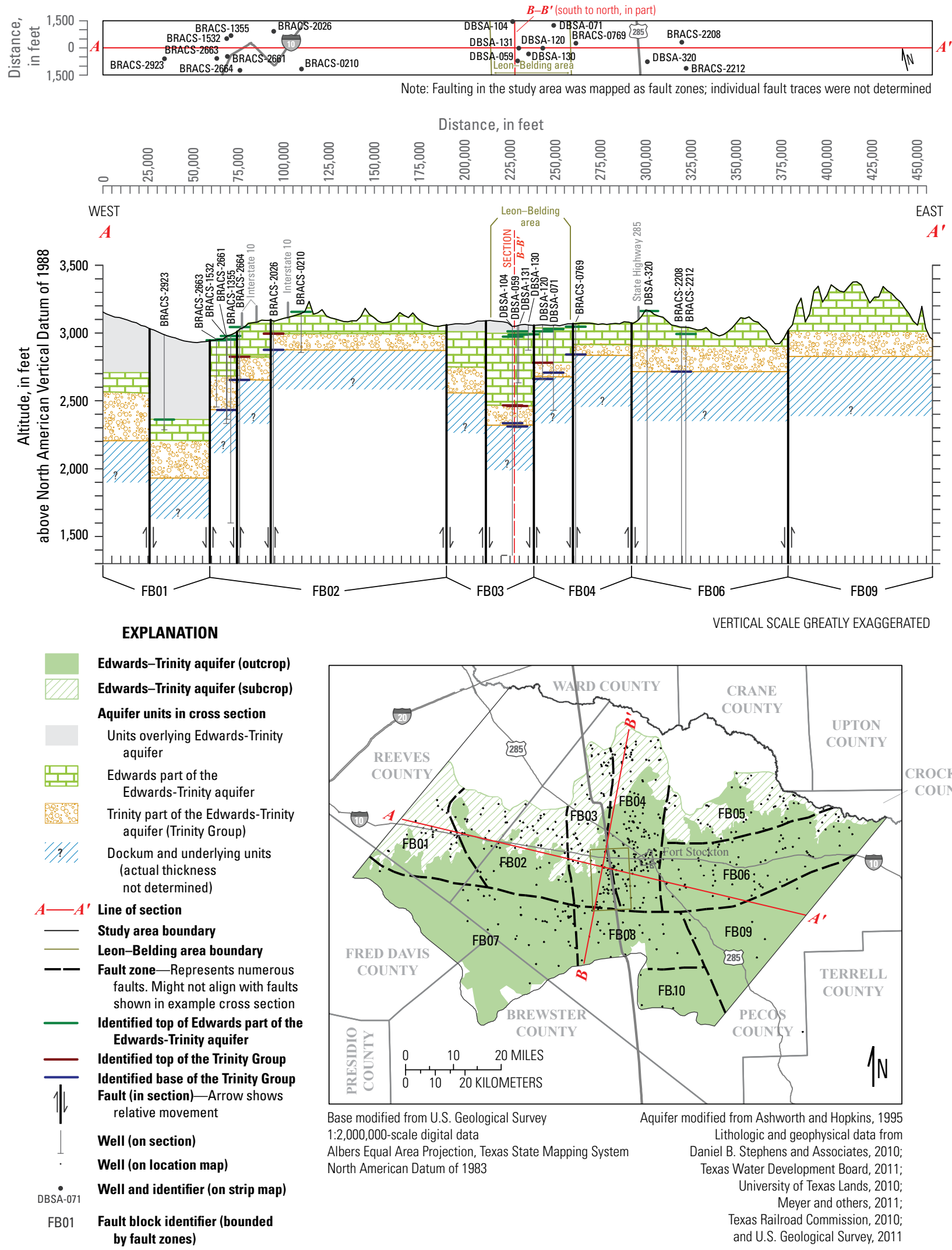

Base modified from U.S. Geological Survey 1:2,000,000-scale digital data

Albers Equal Area Projection, Texas State Mapping System North American Datum of 1983
EAST 

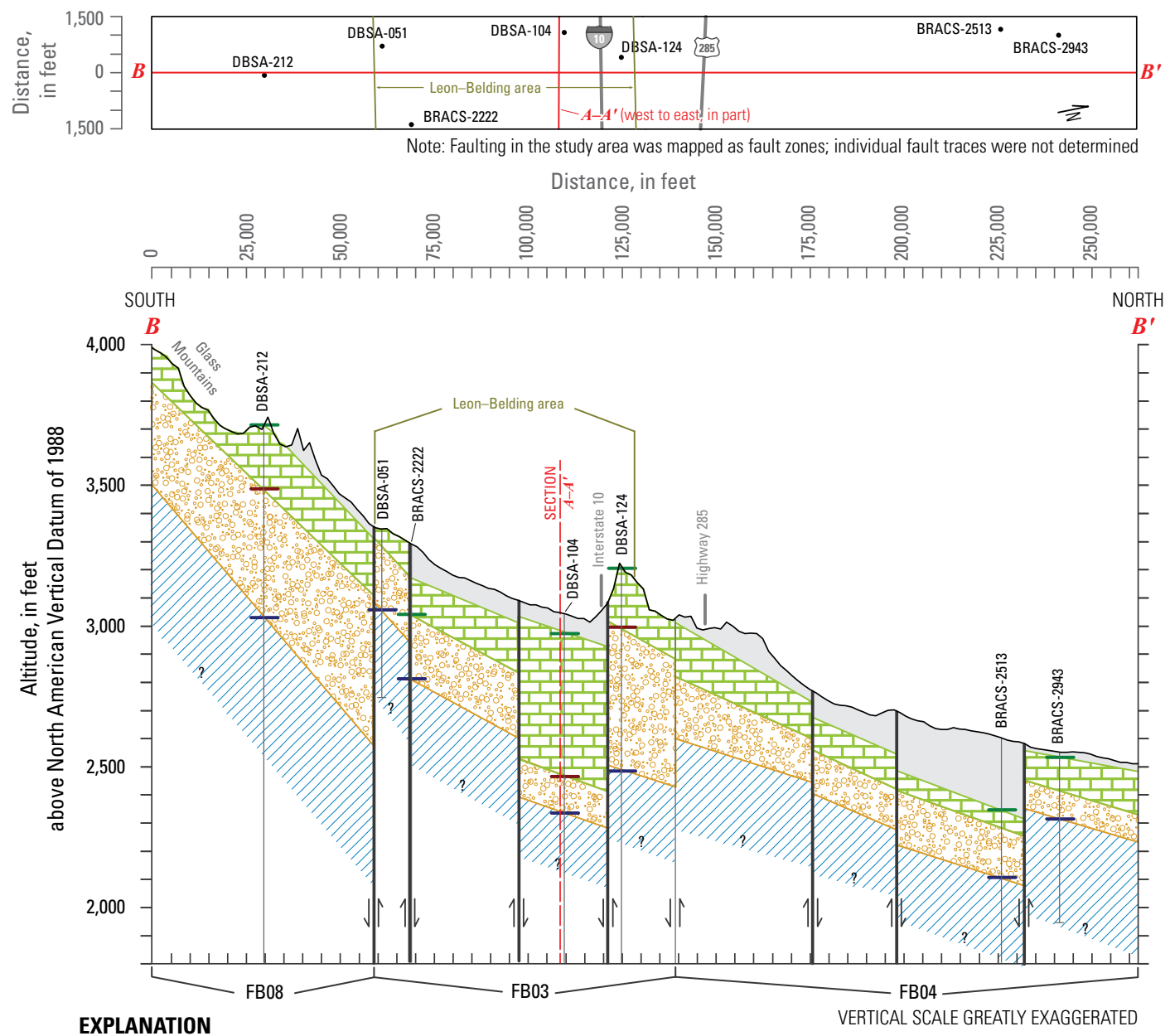

EXPLANATION

Edwards-Trinity aquifer (outcrop)

Edwards-Trinity aquifer (subcrop)

Aquifer units in cross section

Units overlying Edwards-Trinity aquifer

Edwards part of the Edwards-Trinity aquifer

Trinity part of the Edwards-Trinity aquifer (Trinity Group)

Dockum and underlying units (actual thickness not determined)

$B-B^{\prime}$ Line of section

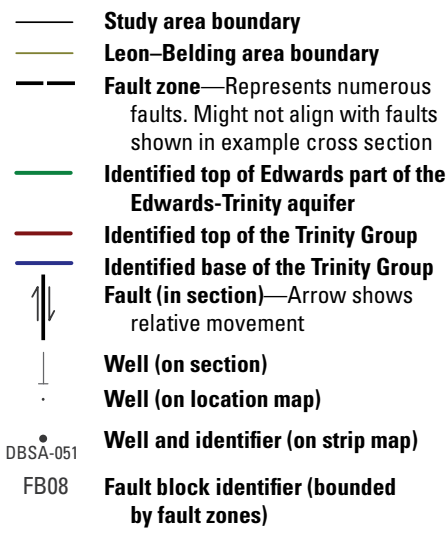

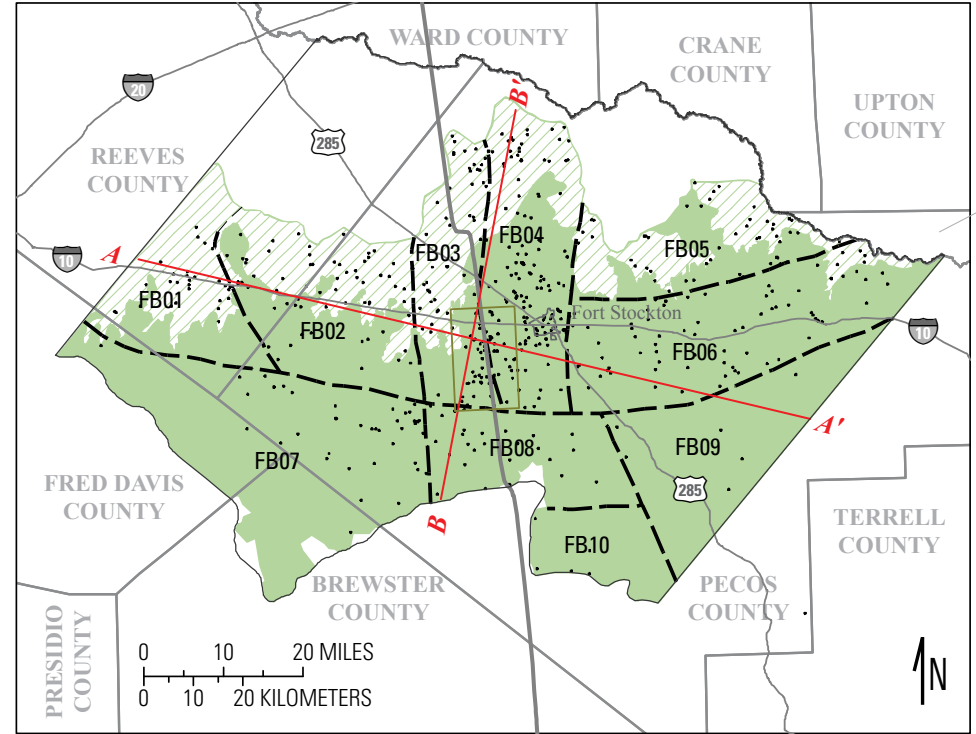

Base modified from U.S. Geological Survey 1:2,000,000-scale digital data Albers Equal Area Projection, Texas State Mapping System

North American Datum of 1983
Aquifer modified from Ashworth and Hopkins, 1995 Lithologic and geophysical data from Daniel B. Stephens and Associates, 2010; Texas Water Development Board, 2011: University of Texas Lands, 2010; Meyer and others, 2011: Texas Railroad Commission, 2010; and U.S. Geological Survey, 2011

Figure 18. Generalized map and detailed cross section $B-B^{\prime}$ in the Pecos County region study area, Texas. 
to flow, but the disconnection at this location is not confirmed and, if it does exist at this location, may not be laterally continuous. Faults east of, and adjacent to, FB01 (fig. 17) stairstep up to a horst (FB02; fig. 17) formed from deposits that overlie more resistant rock units and form a ridge between the Pecos and Monument Draw troughs (fig. 2). Stairstep faults east of the ridge, also created by the dissolution of Permian-age evaporite deposits, form the graben (FB03; fig. 17) that is part of the Monument Draw trough (fig. 2). The next series of stairstep faults form a horst (FB04; fig. 17) to the east of the Monument Draw trough (fig. 2) and are in Cretaceous rocks that overlie the Capitan Reef aquifer (fig. 4). Cross section $\mathrm{A}-\mathrm{A}^{\prime}$ is completed by a graben (FB06; fig. 17) and horst (FB09; fig. 17) that formed east of the Capitan Reef aquifer (fig. 4) (FB04; fig. 17).

Cross-section B-B' originates in the Glass Mountains (fig. 2) along the southern boundary of the study area and extends north to the down-dip extent of the Edwards-Trinity aquifer (fig. 18). There are a series of stairstep fault zones, horsts, and grabens that separate the downthrown trough fault blocks (FB08 and FB03; fig. 18) in the south from the deposits overlying the Capitan Reef aquifer (fig. 4) (FB04; fig. 18) to the north. The intrablock faults correlate closely with thickness variations in the Edwards-Trinity aquifer (figs. 14-16). Also, the fault zones shown in the cross section are likely a fraction of those that formed as growth faults along the margins of the Glass Mountains and resistant Permian-age deposits along the Capitan Reef aquifer and as collapse features from the dissolution of Permian-age evaporite deposits.

\section{Aquifer Tests and Hydraulic Properties}

Aquifer-test data collected at 47 groundwater wells were compiled from other reports or agencies such as the TWDB Groundwater Database (Texas Water Development Board, 2011), Thornhill Group, Inc., (2008, 2009), and Meyers (1969) and used in this study. One aquifer test was completed with ambient and pumping borehole flowmeter measurements by the USGS as part of this study.

Transmissivity is an aquifer hydraulic property that is defined by the rate water is transmitted horizontally through a unit width of an aquifer under a unit hydraulic gradient. It equals the hydraulic conductivity of an aquifer multiplied by the aquifer thickness (or saturated thickness if unconfined) (Fetter, 1988). Higher transmissivity values correlate with higher yields and less drawdown in a well. Previously reported transmissivity values were calculated using one or more of the following methods: the Thiem equilibrium formula (Thiem, 1906), the Theis nonequilibrium formula (Theis, 1935), the Jacob modified formula (Cooper and Jacob, 1946), or methods documented in Ferris and others (1962) and Wenzel (1942).

Most historical aquifer-test data included pump rate or yield in gallons per minute and drawdown, in feet. These data were used to estimate the hydraulic properties (specific capacity and transmissivity) in the study area. Specific capacity can be used to provide the maximum yield for a well and to estimate the transmissivity of an aquifer. Specific capacity is obtained by dividing the pump rate or yield by the total drawdown. Using the Jacob modified formula (Cooper and Jacob, 1946), Driscoll (1986) developed an approximating formula for estimating transmissivity from specific capacity in confined and unconfined aquifers. Transmissivity was estimated from specific capacity using Driscoll's equation for an unconfined aquifer if previously published transmissivity values were not available (Driscoll, 1986, appendix 16D). Driscoll's equation is:

$$
T=1,500 \times Q / s(\text { for an unconfined aquifer })
$$

where

$$
\begin{gathered}
T \quad \begin{array}{c}
\text { is transmissivity, in gallons per day per foot of } \\
\text { drawdown; }
\end{array} \\
Q \quad \text { is well yield or pumping rate, in gallons per } \\
\text { minute; } \\
S \quad \text { is drawdown at any point in the vicinity of a } \\
\text { well discharging at a constant rate, in feet; } \\
\text { and } \\
\text { is specific capacity, in gallons per minute per } \\
\text { foot of drawdown. }
\end{gathered}
$$

The calculated and estimated transmissivity values ranged from 1,500 to 1,216,000 gallons per day per foot of drawdown $[(\mathrm{gal} / \mathrm{d} / \mathrm{ft})]$. The transmissivity value and data source for each well used in this dataset are shown in table 4, at end of report.

Figure 19 shows the distribution of the log of transmissivity values measured in the Edwards-Trinity aquifer in the study area. Although the tests were done at different pumping rates and durations, which limits direct comparison of the results, the map provides a general understanding of transmissivity distributions across the study area. The highest transmissivity values were measured in the Monument Draw trough (fig. 2), which is also one of the thickest parts of the Edwards-Trinity aquifer, and the lowest values were measured in the eastern part of the study, near some of the thinnest parts of the aquifer. Hydraulic conductivity values, which were calculated using the transmissivity values and estimated saturated thickness of the aquifer (Ritzema, 1994), generally showed the same patterns as the transmissivity values (table 4). Faulting within the FB03 fault block (figs. 17-18) in the Leon-Belding area of the Monument Draw trough (figs. 1-2) likely contributed to higher transmissivity values in that area.

\section{Geochemistry}

Variations in the chemistry of groundwater are caused by constituents dissolved in water, reactions among these constituents, reactions between these constituents and minerals in the rocks through which the water flows (water-rock 


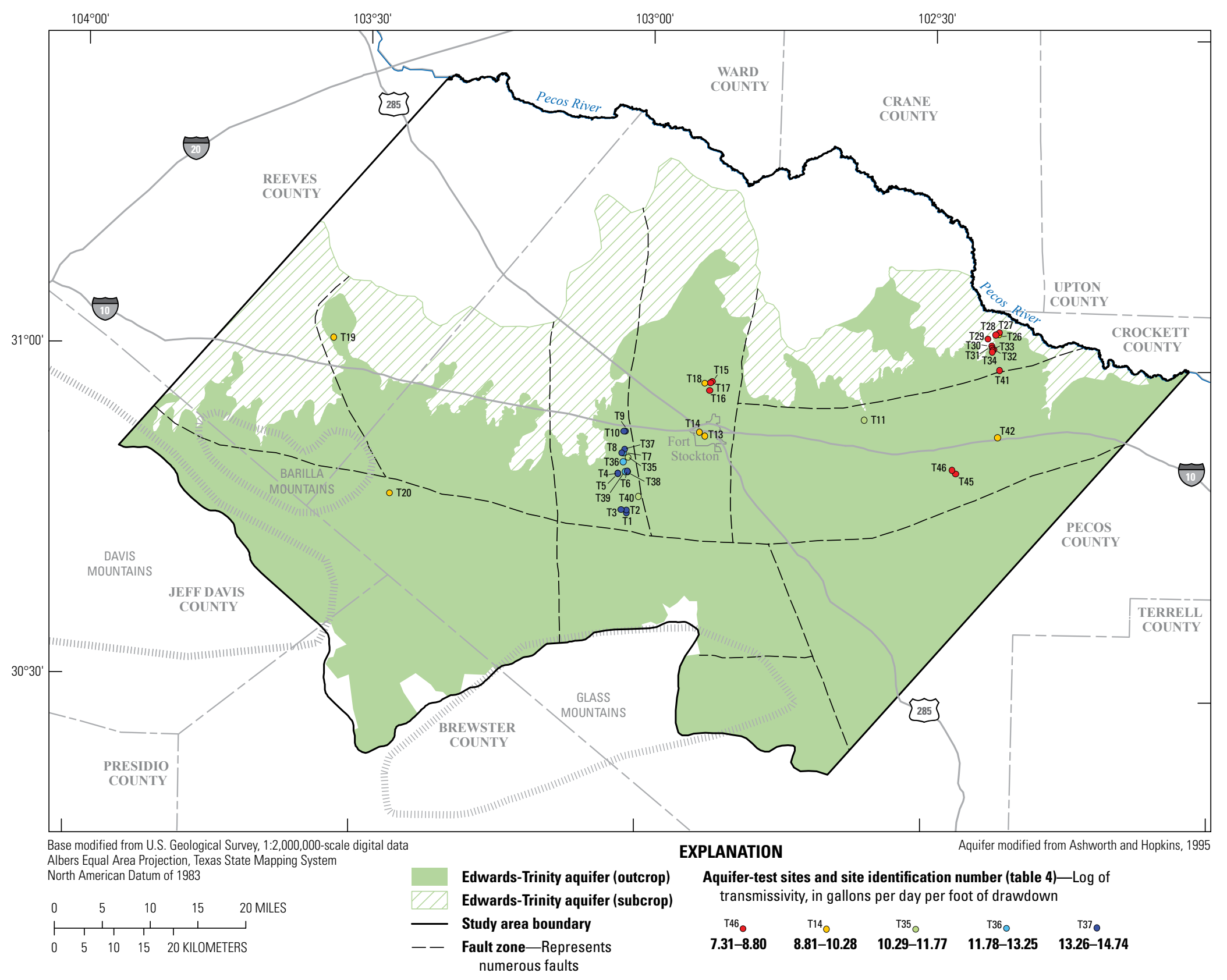

Figure 19. The log of transmissivity values calculated and estimated using aquifer-test data from wells completed in the Edwards-Trinity aquifer in the Pecos County region study area, Texas. 
interaction), and mixing of water from different sources (Hem, 1992; Small and Ozuna, 1993). Interpreting chemical variability in an aquifer provides insight into the quality of the groundwater, hydrologic flow paths, potential recharge sources, extent of water-rock interaction, and groundwater mixing pathways. In order to assess the groundwater chemistry (geochemistry) of the Pecos County region, geochemical samples were collected in the study area in 2010 and 2011 from 38 wells completed in the Pecos Valley, Igneous, Edwards-Trinity, Rustler, Dockum, and Capitan Reef aquifers and four springs as part of the first phase of this study (fig. 20, table 5 at end of report). Pearson and others (2012) describe the methods used for collection, laboratory analysis, and quality control of the data that were collected or compiled for the study area and used in this report. An important revision and update in this report is aquifer codes for several wells contained in the geodatabase, which was developed by Pearson and others (2012), were changed when the sampling interval of the wells were compared to the hydrogeologic framework developed in this phase of the study (table 6 at end of report).

Analysis of the geochemical samples provided insight into the chemical characteristics of water from different sources and different aquifers. Distinct chemical characteristics of these water samples were used to qualitatively evaluate aquifer interaction, groundwater-flow paths, water-rock interaction, mixing of water from different sources, and to identify likely source waters and geochemical endmembers.

Although the Edwards-Trinity aquifer was the focus of the geochemical sampling, samples were collected from other aquifers in the groundwater system in an effort to understand how water from these sources might interact with and affect the Edwards-Trinity aquifer. Only those analytical results most relevant to the understanding of flow paths, potential recharge sources, and mixing pathways of the groundwater system are discussed in this report. Geochemical results are available from the U.S. Geological Survey National Water Information System (NWIS) (U.S. Geological Survey, 2011) and from Pearson and others (2012).

\section{Overview of Geochemical Data}

Geochemical physical properties and constituents used to evaluate aquifer interaction, groundwater-flow paths, waterrock interaction, and mixing of water in the groundwater system include specific conductance, hydrochemical facies, sulfate and chloride concentrations, silica concentrations, stable isotopes of oxygen and hydrogen, strontium isotopes, environmental tracers, and concentrations of organic compounds and nutrients (tables 7 and 8 at end of report). These results were used in combination to identify the chemical characteristics of water from different sources and to determine how water from different sources might be mixing in the groundwater system. The qualitative geochemical analysis does not include a quantitative evaluation of residence times in the aquifer nor does it include geochemical flow-path modeling of the groundwater system.

\section{Specific Conductance}

Specific conductance measures the ability of water to conduct an electrical current and is related to the ion concentration; typically, there is a monotonic relation between specific conductance and the dissolved-solids concentration (Hem, 1992). The specific-conductance values measured in waters in the study area (table 7) are comparable to previously published data (Small and Ozuna, 1993; Uliana and Sharp, 2001; Thornhill Group, Inc., 2008; Texas Water Development Board, 2011). Specific-conductance values were generally quite variable within and between different aquifers. Higher specific conductance values reflecting more saline water were associated with relatively high concentrations of selected major ions, including chloride $(\mathrm{Cl})$, sulfate $\left(\mathrm{SO}_{4}\right)$, sodium $(\mathrm{Na})$, calcium $(\mathrm{Ca})$, and magnesium $(\mathrm{Mg})$. Rainwater has very low specific conductance values (specific-conductance values usually less than 25 microsiemens per centimeter at 25 degrees $[\mu \mathrm{S} / \mathrm{cm}]$ ) (National Atmospheric Deposition Program, 1997). Compared to rainwater, groundwater typically has higher specific conductance resulting from the dissolution of subsurface minerals and rock matrix. Specific conductance in geochemical samples collected in the study area ranged from 273 to $7,260 \mu \mathrm{S} / \mathrm{cm}$ (table 7). The higher specific conductance values in the study area might be caused by the groundwater mixing with more saline groundwater or dissolution of evaporites. In the absence of other sources of salinity, specific conductance values would likely increase along groundwater-flow paths as a result of progressive waterrock interaction.

Specific conductance of water in the four Pecos Valley aquifer wells ranged from 362 to $1,690 \mu \mathrm{S} / \mathrm{cm}$ with an average value of $1,020 \mu \mathrm{S} / \mathrm{cm}$ and median value of 1,020 $\mu \mathrm{S} / \mathrm{cm}$ (fig. 20, table 7). Samples collected from sites Q7 and Q15, which are wells completed in the Igneous aquifer, had specific conductance values of 331 and $408 \mu \mathrm{S} / \mathrm{cm}$, respectively. The average specific conductance value measured in samples from the Igneous aquifer $(370 \mu \mathrm{S} / \mathrm{cm})$ was the lowest of the sampled hydrostratigraphic units. Specific conductance values measured in the samples collected from 20 wells completed in the Edwards-Trinity aquifer ranged from 273 to $7,260 \mu \mathrm{S} / \mathrm{cm}$ with an average value of 2,340 $\mu \mathrm{S} / \mathrm{cm}$ and median value of $1,830 \mu \mathrm{S} / \mathrm{cm}$. The large range of specific conductance values in samples collected from the Edwards-Trinity aquifer indicates that processes such as mixing with recent, local recharge, mixing with more saline water sources, and progressive water-rock interaction along regional groundwater-flow paths might influence groundwater compositions. Higher specific conductance values in the Edwards-Trinity aquifer (relative to the median) generally were measured in samples collected from wells completed in the Monument Draw trough (sites Q14, Q16, Q18, Q22, Q23, Q24, Q26, and Q37); from site Q35, which 


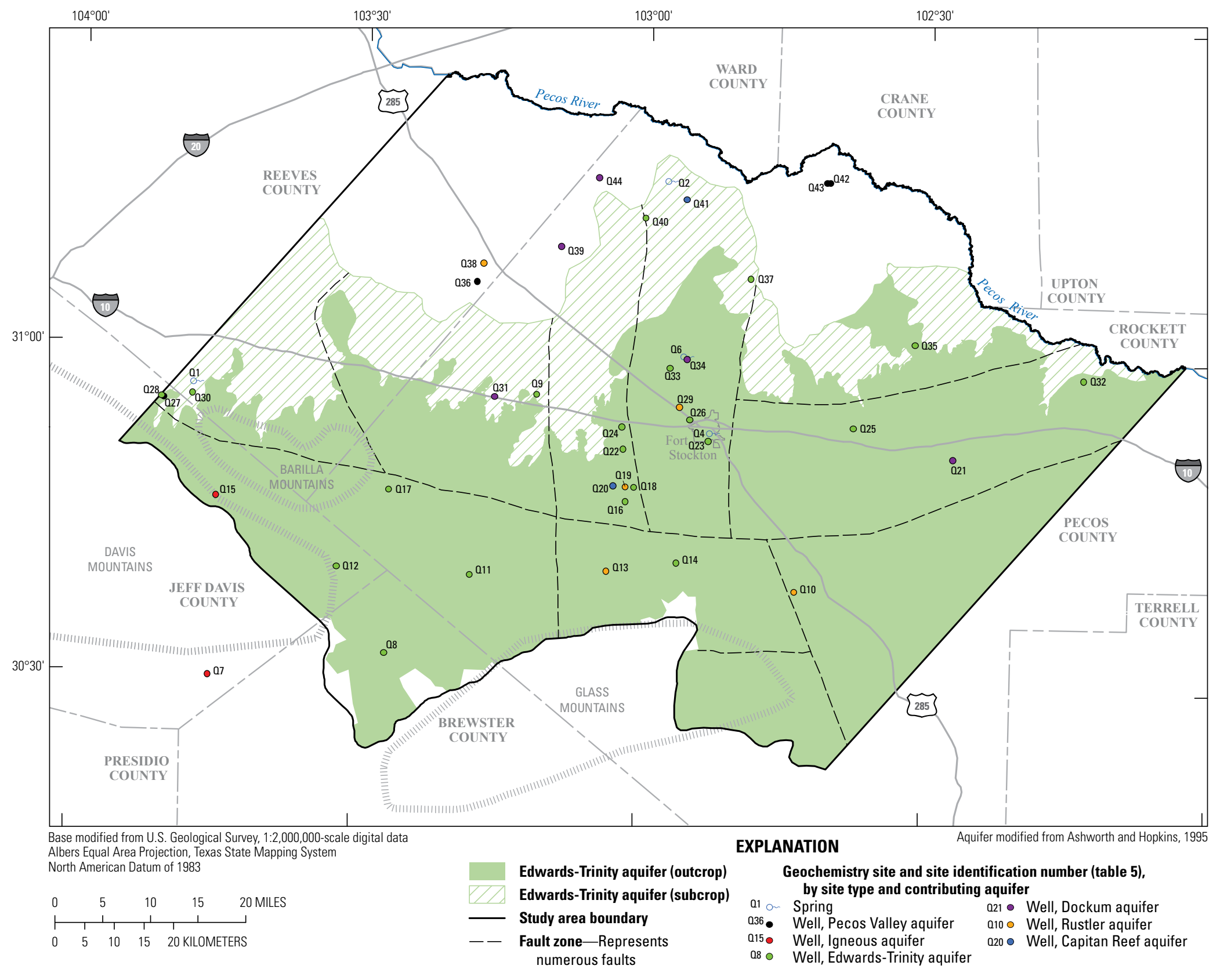

Figure 20. Locations of groundwater-well and spring sites for geochemical data collection in the Pecos County region study area, Texas. 
is located near the down-dip extent of the aquifer; and from site Q30, which is near the western boundary of the study area. Specific conductance values in samples collected from the five wells completed in the Dockum aquifer ranged from 736 to $3,200 \mu \mathrm{S} / \mathrm{cm}$ with an average value of $1,680 \mu \mathrm{S} / \mathrm{cm}$ and median value of $1,560 \mu \mathrm{S} / \mathrm{cm}$. Specific conductance values in samples collected from the five wells completed in the Rustler aquifer ranged from 553 to $3,980 \mu \mathrm{S} / \mathrm{cm}$ with an average value of $2,030 \mu \mathrm{S} / \mathrm{cm}$ and median value of 2,050 $\mu \mathrm{S} / \mathrm{cm}$. Samples collected from sites Q20 and Q41, which are wells completed in the Capitan Reef aquifer, had specific conductance values of 2,290 and $4,160 \mu \mathrm{S} / \mathrm{cm}$, respectively. The average specific-conductance value measured in samples from the Capitan Reef aquifer $(3,230 \mu \mathrm{S} / \mathrm{cm})$ was the highest of the sampled hydrostratigraphic units. The specific conductance measured in samples collected from the four springs in the study area (sites Q1, Q2, Q4, and Q6) ranged from 2,430 to $6,730 \mu \mathrm{S} / \mathrm{cm}$ with an average value of $4,710 \mu \mathrm{S} /$ $\mathrm{cm}$ and median value of $4,840 \mu \mathrm{S} / \mathrm{cm}$. The average specificconductance value measured in samples from the spring sites was higher than the samples collected from any of the hydrostratigraphic units (fig. 20, table 7).

\section{Hydrochemical Facies}

The composition of groundwater principally is controlled by the composition of recharge water, water-rock interaction, and the mixing of water from different sources. The term "facies" refers to a classification scheme used to describe water in terms of the major cation and anion milliequivalents composition (figs. 20 and 21, table 7). A trilinear ("Piper") diagram (Piper, 1953) is a useful tool for evaluating the relative abundance of major cations and anions and classifying facies or water types. Hydrochemical facies were complex and varied between and within the aquifers in the study area. Variations in facies were predominantly associated with different locations in the study area and likely result from localized groundwater processes and progressive mineralization along groundwater-flow paths. Facies ranged from simple, such as $\mathrm{Na}-\mathrm{HCO}_{3}$ type water, to complex, such as $\mathrm{Na}-\mathrm{Ca}-\mathrm{Mg}-\mathrm{SO}_{4}-\mathrm{Cl}-\mathrm{HCO}_{3}$ type water.

\section{Sulfate and Chloride Concentrations}

Variations in $\mathrm{SO}_{4}$ and $\mathrm{Cl}$ concentrations in groundwater and their relations with other major and trace elements can be used to qualitatively assess water-rock interaction with evaporite deposits, such as anhydrite $\left(\mathrm{CaSO}_{4}\right)$, gypsum $\left(\mathrm{CaSO}_{4} \cdot 2 \mathrm{H}_{2} \mathrm{O}\right)$, and halite $(\mathrm{NaCl})$. The groundwater $\mathrm{SO}_{4}$ and $\mathrm{Cl}$ concentrations measured in the study area (figs. 20 and 22, table 7) are comparable to previously published data (Small and Ozuna, 1993; Uliana and Sharp, 2001; Thornhill Group, Inc., 2008; Texas Water Development Board, 2011) and the variability in ranges generally corresponded with specific conductance. $\mathrm{SO}_{4}$ concentrations in the Pecos Valley aquifer ranged from 11.8 to 3,020 milligrams per liter $(\mathrm{mg} / \mathrm{L})$ with an average value of $1,440 \mathrm{mg} / \mathrm{L}$ and median value of $1,360 \mathrm{mg} / \mathrm{L}$, and $\mathrm{Cl}$ concentrations ranged from 7.16 to $4,770 \mathrm{mg} / \mathrm{L}$ with an average of $2,190 \mathrm{mg} / \mathrm{L}$ and median value of $2,000 \mathrm{mg} / \mathrm{L}$. SO concentrations were 12.9 and $16.0 \mathrm{mg} / \mathrm{L}$ and $\mathrm{Cl}$ concentrations were 8.39 and $8.81 \mathrm{mg} / \mathrm{L}$ for samples from wells completed in the Igneous aquifer (sites Q7 and Q15, respectively). $\mathrm{SO}_{4}$ concentrations in the Edwards-Trinity aquifer ranged from 12.2 to $2,010 \mathrm{mg} / \mathrm{L}$ with an average value of $537 \mathrm{mg} / \mathrm{L}$ and median value of $358 \mathrm{mg} / \mathrm{L}$, and $\mathrm{Cl}$ concentrations ranged from 5.16 to $1,370 \mathrm{mg} / \mathrm{L}$ with an average value of 363 $\mathrm{mg} / \mathrm{L}$ and median value of $282 \mathrm{mg} / \mathrm{L}$. Relatively higher concentrations of both $\mathrm{SO}_{4}$ and $\mathrm{Cl}$ were measured in samples collected from Edwards-Trinity aquifer sites Q14, Q16, Q18, Q22, Q23, Q24, Q26, Q30, Q35, and Q37, which are the same wells with relatively high specific conductance. $\mathrm{SO}_{4}$ concentrations in the Dockum aquifer ranged from 91.8 to $586 \mathrm{mg} / \mathrm{L}$ with an average value of $296 \mathrm{mg} / \mathrm{L}$ and median value of $335 \mathrm{mg} / \mathrm{L}$, and $\mathrm{Cl}$ concentrations ranged from 58.2 to $675 \mathrm{mg} / \mathrm{L}$ with an average value of $265 \mathrm{mg} / \mathrm{L}$ and median value of $195 \mathrm{mg} / \mathrm{L} . \mathrm{SO}_{4}$ concentrations in the Rustler aquifer ranged from 52.5 to $2,270 \mathrm{mg} / \mathrm{L}$ with an average value of $748 \mathrm{mg} / \mathrm{L}$ and median value of $357 \mathrm{mg} / \mathrm{L}$, and $\mathrm{Cl}$ concentrations ranged from 23.5 to $332 \mathrm{mg} / \mathrm{L}$ with an average value of $194 \mathrm{mg} / \mathrm{L}$ and median value of $179 \mathrm{mg} / \mathrm{L} . \mathrm{SO}_{4}$ concentrations in samples collected from wells completed in the Capitan Reef aquifer (sites Q20 and Q41) were 421 and $2,320 \mathrm{mg} / \mathrm{L}$, and $\mathrm{Cl}$ concentrations were 370 and 354 $\mathrm{mg} / \mathrm{L}$, respectively. The $\mathrm{SO}_{4}$ concentration relative to the $\mathrm{Cl}$ concentration measured in samples collected from two sites (site Q29, completed in the Rustler aquifer and site Q41, completed in the Capitan Reef aquifer), deviated from the generally linear pattern of the rest of the measured values (fig. 22). The relatively higher concentration of $\mathrm{SO}_{4}$ at these sites indicates groundwater interaction with a higher $\mathrm{SO}_{4}$ source compared to the other sites, possibly from evaporite deposits of anhydrite and gypsum. $\mathrm{SO}_{4}$ concentrations measured in spring water (sites Q1, Q2, Q4, and Q6) ranged from 437 to $1,890 \mathrm{mg} / \mathrm{L}$ with an average value of $1,220 \mathrm{mg} / \mathrm{L}$ and median value of $1,270 \mathrm{mg} / \mathrm{L}$, and $\mathrm{Cl}$ concentrations ranged from 431 to $1,220 \mathrm{mg} / \mathrm{L}$ with an average value of $849 \mathrm{mg} / \mathrm{L}$ and median value of $873 \mathrm{mg} / \mathrm{L}$.

\section{Silica Concentrations}

Variations in silica $(\mathrm{Si})$ concentrations in groundwater can be used to qualitatively assess water-rock interaction with rocks composed of silicate minerals (Hem, 1992). The groundwater Si concentrations measured in the study area (fig. 20, table 7) are comparable to previously published data (Texas Water Development Board, 2011). Si concentrations in the Pecos Valley aquifer ranged from 22.6 to $53.5 \mathrm{mg} / \mathrm{L}$ with an average value of $34.0 \mathrm{mg} / \mathrm{L}$ and median value of $29.8 \mathrm{mg} / \mathrm{L}$. Si concentrations were 43.6 and $43.4 \mathrm{mg} / \mathrm{L}$ in samples collected from wells completed in the Igneous aquifer (sites Q7 and Q15, respectively) with an average value of $43.5 \mathrm{mg} / \mathrm{L}$, which was the highest average value among the 


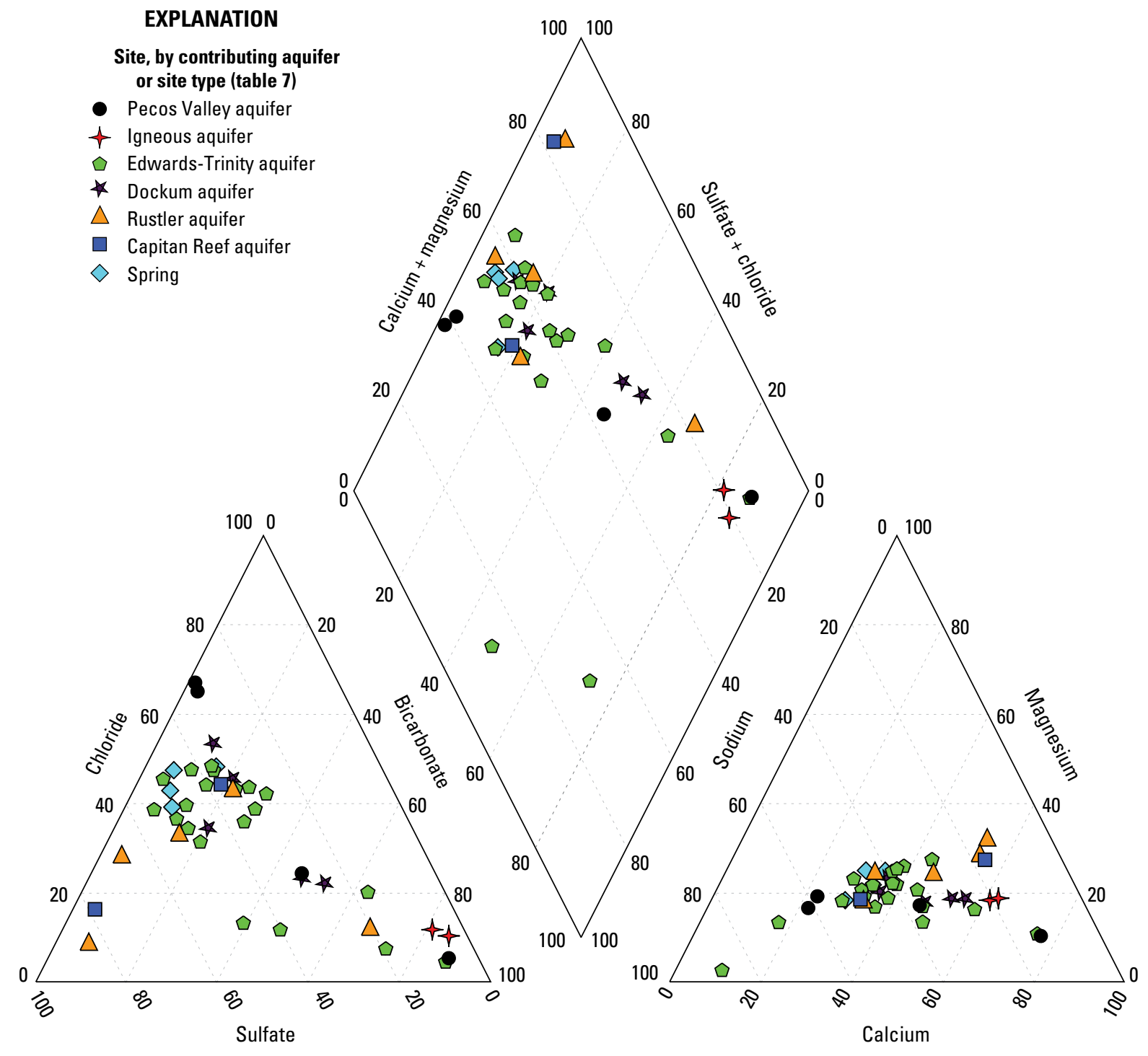

Milliequivalents, in percent

Figure 21. Trilinear diagram showing relations between major cations and anions in groundwater and spring water collected in the Pecos County region study area, Texas.

aquifers. Si concentrations in the Edwards-Trinity aquifer ranged from 10.4 to $52.0 \mathrm{mg} / \mathrm{L}$ with an average value of $21.6 \mathrm{mg} / \mathrm{L}$ and median value of $20.8 \mathrm{mg} / \mathrm{L}$. Si concentrations in the Dockum aquifer ranged from 11.1 to $30.9 \mathrm{mg} / \mathrm{L}$ with an average value of $19.8 \mathrm{mg} / \mathrm{L}$ and median value of $16.2 \mathrm{mg} / \mathrm{L}$. $\mathrm{Si}$ concentrations in the Rustler aquifer ranged from 0.479 to $19.6 \mathrm{mg} / \mathrm{L}$ with an average value of $13.4 \mathrm{mg} / \mathrm{L}$ and median value of $14.0 \mathrm{mg} / \mathrm{L}$. Si concentrations in samples collected from wells completed in the Capitan Reef aquifer (sites Q20 and Q41) were 21.0 and $13.9 \mathrm{mg} / \mathrm{L}$. Si concentrations measured in spring water ranged from 22.8 to $35.4 \mathrm{mg} / \mathrm{L}$ with an average value of $28.9 \mathrm{mg} / \mathrm{L}$ and median value of $28.7 \mathrm{mg} / \mathrm{L}$.

\section{Stable Isotopes}

Citing the work of Faure (1986), Uliana and others (2007, p. 338) noted that oxygen and hydrogen isotopes of the water molecule are indicators of conditions present at the time and place of groundwater recharge. The ratios of oxygen-18/ oxygen-16 isotopes $\left(\delta^{18} \mathrm{O}\right.$ in per mil) and hydrogen-2/ hydrogen-1 ( $\delta \mathrm{D}$ in per mil) are compared to the global meteoric water line (MWL) of Craig (1961), which represents the composition of rainfall around the globe. Stable isotope values for groundwater and spring water in the study area also were compared to annual weighted mean precipitation values $\left(-6.50\right.$ per mil and -44.0 per mil for $\delta^{18} \mathrm{O}$ and $\delta \mathrm{D}$, respectively, 


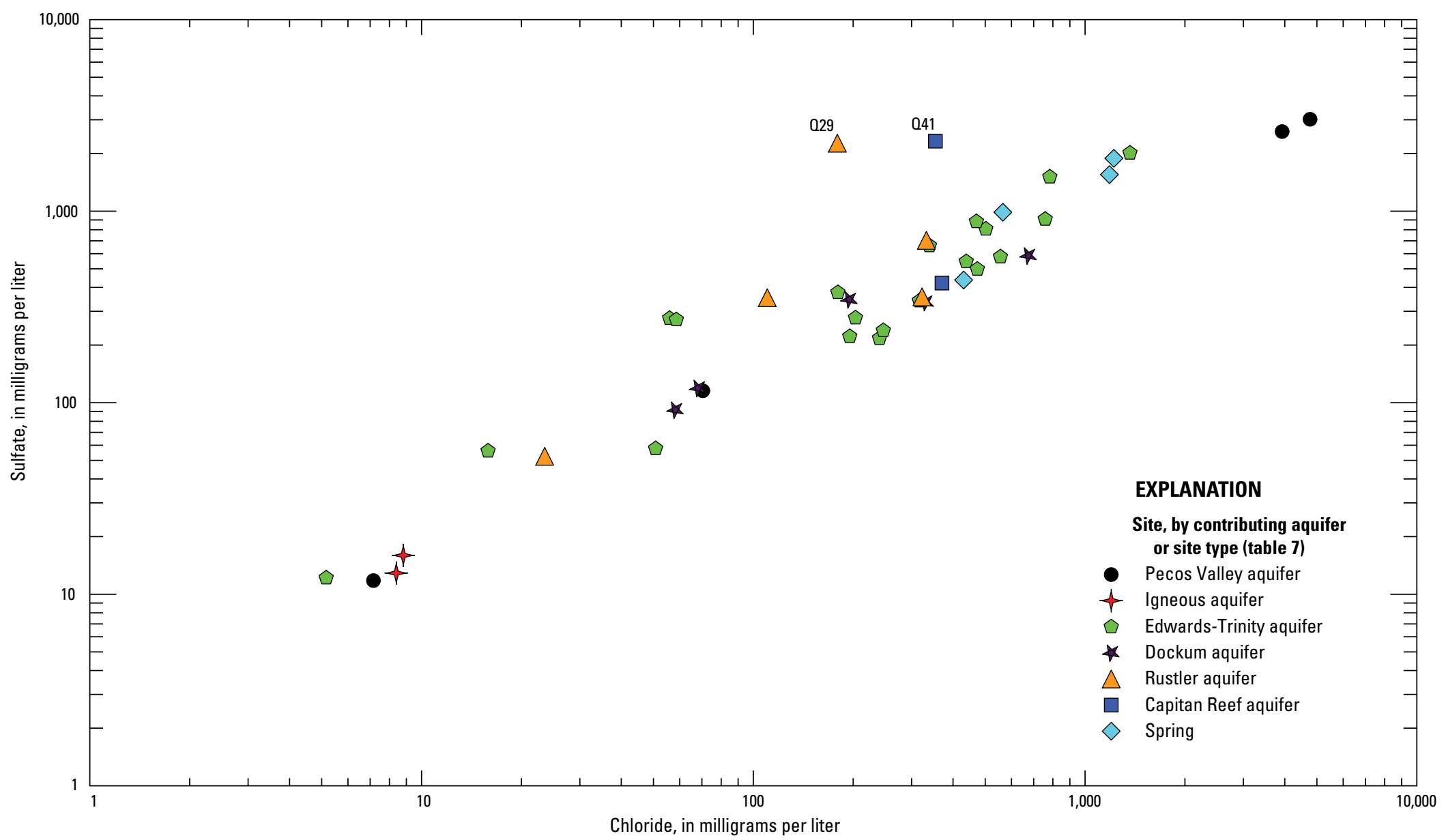

Figure 22. Relation between sulfate concentrations and chloride concentrations for samples collected from groundwater and spring sites in the Pecos County region study area, Texas. 
1962-1988) from the nearest Global Network of Isotopes in Precipitation (GNIP) station (site 7622500 at Chihuahua, Mexico, about 300 miles southwest of Fort Stockton, Tex., at an altitude of about 4,670 $\mathrm{ft}$ [International Atomic Energy Agency, 2011]) and to estimates of stable isotope values in precipitation for the Trans-Pecos region made by Uliana and others (2007). Stable isotope results of samples collected for this study were compared to those of Uliana and others (2007) to help determine if the isotopic compositions measured were consistent with recent, local recharge (recharge during the Holocene and in the study area) or if the isotopic composition was indicative of other hydrologic processes (fig. 23, table 7). Uliana and others (2007) estimated that precipitation presently occurring to the south and west of the study area would have $\delta^{18} \mathrm{O}$ values that range from -7.50 to -5.70 per mil. Stable isotope values that plot along the MWL near the present precipitation estimates likely reflect a dominant component of water that recharged under recent, local climatic conditions (hereinafter referred to as young water). Values that plot along the MWL and lower than the present precipitation estimates are consistent with a component of water that recharged during the wetter, cooler climate of the late Pleistocene (hereinafter referred to as old water) (Uliana and others, 2007). For the purposes of this study, samples with $\delta^{18} \mathrm{O}$ values from -8.34 per mil (the lowest measured value, at site Q30) to -7.50 per mil are considered to be dominated by old water; values greater than -7.50 per mil are considered to be young water. Values that substantially deviate from the MWL indicate that the water has been affected by processes such as evaporation or extensive water-rock interaction.

The $\delta^{18} \mathrm{O}$ and $\delta \mathrm{D}$ values for samples collected in the Pecos County region study area are comparable to those reported by Uliana and others (2007). Groundwater in the Pecos Valley aquifer is predominately consistent with recent, local recharge (figs. 20, 23, and 24, table 7). The values measured in samples collected from sites Q42 and Q43 in the Pecos Valley aquifer substantially deviate from the MWL and indicate some evaporation of the water likely occurred prior to recharge (fig. 23). $\delta^{18} \mathrm{O}$ and $\delta \mathrm{D}$ values for samples from the Igneous aquifer had the highest values along the MWL; these samples likely represent recent, local recharge water. $\delta^{18} \mathrm{O}$ and $\delta \mathrm{D}$ values for samples from the Edwards-Trinity aquifer lie along the MWL but cover a broad range from -8.34 to -6.42 per mil in $\delta^{18} \mathrm{O}$ values; this range, with values higher and lower than -7.50, indicates that the Edwards-Trinity aquifer groundwater samples include varying mixtures of recent, local recharge and water that recharged during different climatic conditions. The lowest Edwards-Trinity aquifer $\delta^{18} \mathrm{O}$ value was measured at site Q30, which is interpreted to be dominated by older (Pleistocene) recharge; the highest value, which was similar to values measured for the Igneous aquifer, was measured in samples from site Q9, which is consistent with recent, local recharge. $\delta^{18} \mathrm{O}$ and $\delta \mathrm{D}$ values for samples from the Dockum aquifer are consistent with recent, local recharge. $\delta^{18} \mathrm{O}$ and $\delta \mathrm{D}$ values measured for samples from the Rustler aquifer in the Monument Draw trough (sites Q13, Q19, and
Q29), from the Capitan Reef aquifer, and from San Solomon and Comanche springs (sites Q1 and Q4, respectively) indicate these water samples are dominated by older recharge. The values for samples from the remaining two Rustler wells (sites Q10 and Q38) indicate the groundwater reflects recent, local recharge. $\delta^{18} \mathrm{O}$ and $\delta \mathrm{D}$ values for samples from Santa Rosa and Diamond Y springs (sites Q2 and Q6, respectively) are consistent with recent, local recharge, but also fall slightly below the MWL. Because a discharge orifice could not be located at either of these springs, pools created by the springs were sampled (Pearson and others, 2012). Evaporation could have occurred from the pool and surface runoff from land adjacent to the spring pools could also have flowed into these pools. The extent of these processes is unknown but might account for stable isotope values slightly below the MWL.

\section{Strontium Isotopes}

Strontium ( $\mathrm{Sr}$ ) commonly substitutes for $\mathrm{Ca}$ in mineral complexes in low-temperature aqueous geochemical environments and is a common trace element in carbonate rocks (Musgrove and others, 2009; Banner, 2004). As a result, $\mathrm{Sr}$ isotopes have been used to evaluate sources of dissolved constituents to groundwater and water-rock interaction processes and to gain insights into regional groundwater-flow paths and groundwater mixing (Musgrove and Banner, 1993; Banner and others, 1994; Uliana and others, 2007; Musgrove and others, 2009). The $\mathrm{Sr}$ isotopic ratio $\left({ }^{87} \mathrm{Sr} /{ }^{86} \mathrm{Sr}\right)$ often provides a useful diagnostic signal of the source of dissolved constituents to a fluid because ${ }^{87} \mathrm{Sr} /{ }^{86} \mathrm{Sr}$ undergoes negligible fractionation during mineral-solution reactions (Banner, 2004). This lack of fractionation makes them particularly useful in tracing regional groundwater-flow paths and identifying mixing relations in regional flow systems (Banner and Kaufman, 1994). Uliana and others (2007) detail the origins of many ${ }^{87} \mathrm{Sr} r{ }^{86} \mathrm{Sr}$ signatures in the Trans-Pecos region.

Because of water-rock interaction processes and negligible fractionation, groundwater that is in equilibrium with the strontium-bearing minerals in aquifer rocks is expected to have ${ }^{87} \mathrm{Sr} /{ }^{86} \mathrm{Sr}$ values that reflect the isotopic ratio of the minerals (Banner and Kaufman, 1994; Uliana and others, 2007). The average ${ }^{87} \mathrm{Sr} r{ }^{86} \mathrm{Sr}$ value reported by Cameron and others (1996) for igneous rocks in the Davis Mountains was 0.7067 and Uliana and others (2007) used a range of values from 0.7030 to 0.7080 . Permian and Cretaceous-age carbonate and evaporite rocks should range from 0.7068 to 0.7084 (Burke and others, 1982; Brookins 1988; Denison and others, 1998). In general, siliciclastic rocks often have higher ${ }^{87} \mathrm{Sr} /{ }^{86} \mathrm{Sr}$ values than carbonate rocks because many siliciclastics contain rubidium-87 $\left({ }^{87} \mathrm{Rb}\right)$-bearing minerals (Faure, 1986). ${ }^{87} \mathrm{Rb}$ is radioactive and decays to ${ }^{87} \mathrm{Sr}$, which increases the ${ }^{87} \mathrm{Sr} /{ }^{86} \mathrm{Sr}$ ratios in siliciclastic rocks. Therefore, the siliciclastic rocks that compose the Pecos Valley and Dockum aquifers, as well as siliciclastic rocks that are components of the predominately carbonate Permian and Cretaceous-age units (table 1), likely have higher ${ }^{87} \mathrm{Sr} /{ }^{86} \mathrm{Sr}$ 


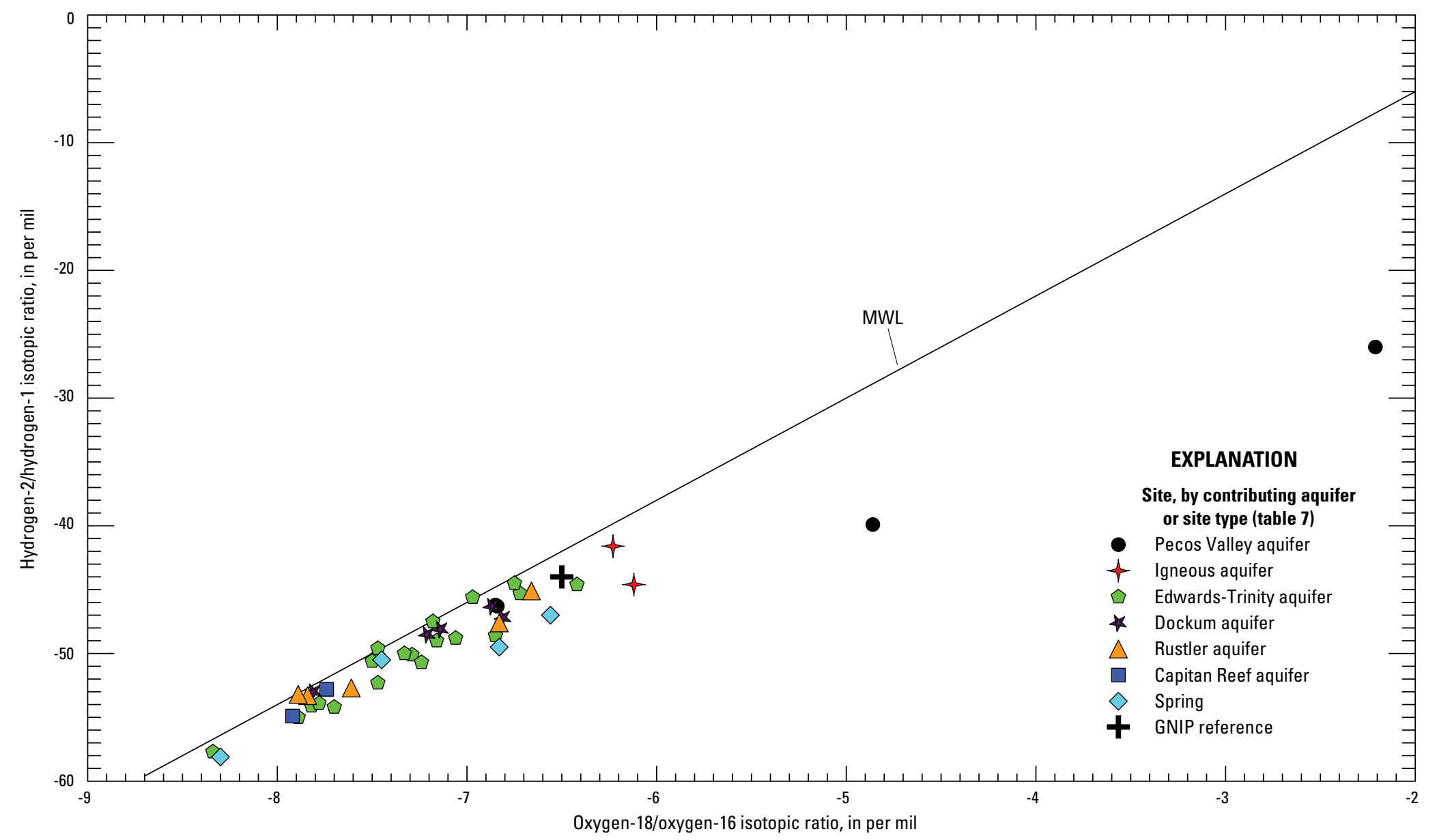

[MWL, global meteroric water line; GNIP, Global Network of Isotopes in Precipitation station 7622500 at Chihuahua, Mexico]

Figure 23. Relation between oxygen-18/oxygen-16 and hydrogen-2/hydrogen-1 isotopic ratios for samples collected from groundwater and spring sites in the Pecos County region study area, Texas, and the global meteoric water line (Craig, 1961). 


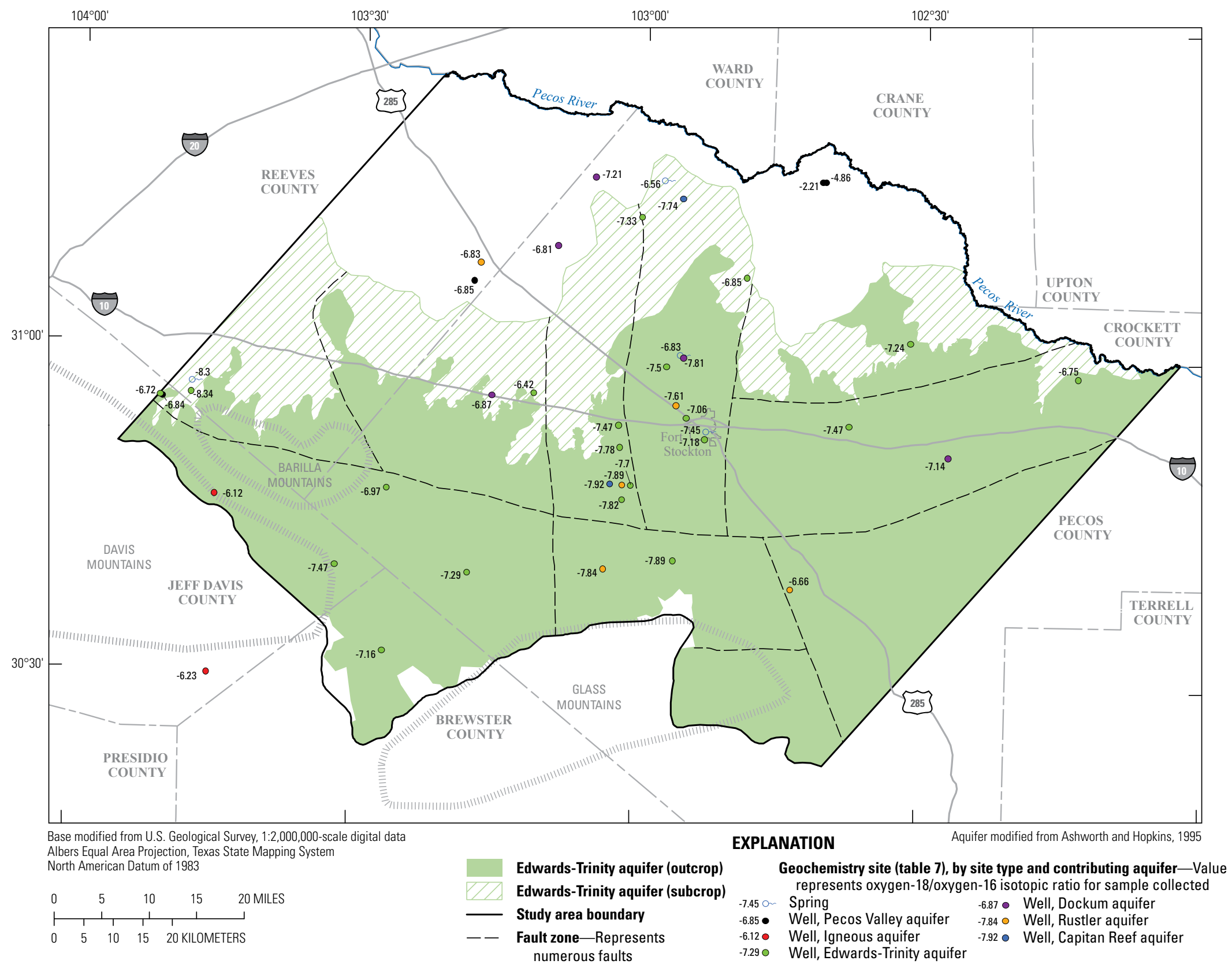

Figure 24. Oxygen-18/oxygen-16 isotopic ratios for samples collected from groundwater and spring sites in the Pecos County region study area, Texas. 
values than the carbonate rocks in the groundwater system. For example, although outside the Pecos County region study area, Langman and Ellis (2010) reported a ${ }^{87} \mathrm{Sr} /{ }^{86} \mathrm{Sr}$ value of 0.7091 for a rock sample collected from the Dockum Group in the southern High Plains region of Texas.

Ratios of ${ }^{87} \mathrm{Sr} /{ }^{86} \mathrm{Sr}$ measured in water samples collected in the study area (figs. 20, 25, and 26, table 7) are comparable to those reported by Uliana and others (2007). Ratios of ${ }^{87} \mathrm{Sr} /{ }^{86} \mathrm{Sr}$ in samples collected from the Pecos Valley aquifer ranged from 0.70799 to $0.70839 .{ }^{87} \mathrm{Sr} /{ }^{86} \mathrm{Sr}$ values in samples collected from the Igneous aquifer were 0.70727 and 0.70757 (sites Q7 and Q15, respectively). These values were low relative to the other aquifers, reflecting interaction with low ${ }^{87} \mathrm{Sr} /{ }^{86} \mathrm{Sr}$ igneous rocks. ${ }^{87} \mathrm{Sr} /{ }^{86} \mathrm{Sr}$ values in samples collected from the Edwards-Trinity aquifer covered a broad range from 0.70788 to 0.70979 ; the higher ${ }^{87} \mathrm{Sr} /{ }^{86} \mathrm{Sr}$ values in this range (greater than 0.70900 ) were measured in samples from nearly all of the wells completed in the Monument Draw trough: site Q25, in the eastern part of the study area, site Q11 in the southern part of the study area, and site Q30 near the western boundary of the study area (fig. 20). Also, because 14 of the 20 EdwardsTrinity aquifer ${ }^{87} \mathrm{Sr} r{ }^{86} \mathrm{Sr}$ values were higher than the expected range of values for groundwater interacting with Cretaceousage carbonate rocks ( 0.7068 to 0.7084 ; Burke and others, 1982), it is expected that there are alternative or additional sources (siliciclastics) of $\mathrm{Sr}$ within the interpreted complex stratigraphy and structural geology of the Pecos County region (fig. 2, table 1). ${ }^{87} \mathrm{Sr} r{ }^{86} \mathrm{Sr}$ values in samples collected from the Dockum aquifer ranged from 0.70843 to 0.70975 ; values greater than 0.70900 were measured at site Q34, which is a well completed in Monument Draw trough, and at site Q21, which is near the eastern boundary of the study area. ${ }^{87} \mathrm{Sr} /{ }^{86} \mathrm{Sr}$ values in samples collected from the Rustler aquifer ranged from 0.70758 to 0.70977 and ${ }^{87} \mathrm{Sr} r{ }^{86} \mathrm{Sr}$ values in samples collected from the Capitan Reef aquifer sites Q20 and Q41 were 0.70969 and 0.70751 , respectively. Like Cretaceousage carbonate rocks, the expected range of ${ }^{87} \mathrm{Sr} /{ }^{86} \mathrm{Sr}$ values for water interacting with the Permian-age carbonate and evaporite rocks of the Rustler and Capitan Reef aquifers is from 0.7068 to 0.7084 (Brookins 1988; Denison and others, 1998), and values higher than this range indicate an alternative or additional source for $\mathrm{Sr}$ in the groundwater. ${ }^{87} \mathrm{Sr} /{ }^{86} \mathrm{Sr}$ ratios in samples collected from the four springs ranged from 0.70898 to 0.70991 and were generally high relative to other samples and higher than the values expected for groundwater interacting with carbonate and evaporite rocks of Permian and Cretaceous age.

\section{Environmental Tracers}

Among their many uses, environmental tracers are useful for understanding when groundwater recharge occurred, isolating the water from the atmosphere. Samples were collected at select sites in the study area and analyzed for tritium $\left({ }^{3} \mathrm{H}\right)$ and (or) helium-3 $\left({ }^{3} \mathrm{He}\right)$ to gain insights regarding the age of the groundwater. ${ }^{3} \mathrm{H}$ is a radioactive isotope of hydrogen with a half-life of 12.32 years and commonly is measured in picocuries per liter (pCi/L) or tritium units (TU), in which $3.22 \mathrm{pCi} / \mathrm{L}$ equals $1 \mathrm{TU}$ (Lucas and Unterweger, 2000). ${ }^{3} \mathrm{H}$ in rainfall has two sources, natural cosmogenic ${ }^{3} \mathrm{H}$ or that produced by the widespread atmospheric testing of nuclear weapons that began around 1950 and continued until about 1970. Given its relatively short half-life, the presence of ${ }^{3} \mathrm{H}$ in groundwater is indicative of groundwater recharge that occurred in the last 60 years (that is "post-bomb" recharge; Clark and Fritz, 1997). The input of ${ }^{3} \mathrm{H}$ to the atmosphere as a result of nuclear testing elevated ${ }^{3} \mathrm{H}$ concentrations in rainfall compared to pre-bomb concentrations for more than 50 years (beginning in the 1950s), with concentrations peaking in the 1960s. ${ }^{3} \mathrm{H}$ concentrations in rainfall since 2006 have globally decreased to approximately pre-bomb background levels of about 2 to 10 TU (Clark and Fritz, 1997; Phillips and Castro, 2003).

Interpreting groundwater ages with ${ }^{3} \mathrm{H}$ is qualitative in that it can provide insight into distinguishing between prebomb and post-bomb water but not determine apparent ages. The ${ }^{3} \mathrm{H} /{ }^{3} \mathrm{He}$ method, which is based on the radioactive decay of ${ }^{3} \mathrm{H}$ to ${ }^{3} \mathrm{He}$, can be used to estimate groundwater ages at a higher resolution than using only ${ }^{3} \mathrm{H}$ concentrations (Schlosser and others, 1988; Schlosser and others, 1989; Solomon and Cook, 1999). Samples were collected for ${ }^{3} \mathrm{H}-{ }^{3} \mathrm{He}$ analysis, but these results were not available at the time this report was prepared (March 2012). ${ }^{3} \mathrm{H}$ decay is not the only possible source of ${ }^{3} \mathrm{He}$, and groundwater-age determination required an assessment of other possible ${ }^{3} \mathrm{He}$ sources. That assessment typically includes measurement of helium-4 $\left({ }^{4} \mathrm{He}\right)$ to aid in distinguishing between He sources (Thatcher and others, 1977).

Sites with ${ }^{3} \mathrm{H}$ concentrations greater than $1 \mathrm{TU}$ were considered to potentially represent water with a sufficient component of post-bomb water for ${ }^{4} \mathrm{He}$ screening and potential ${ }^{3} \mathrm{H} /{ }^{3} \mathrm{He}$ dating (fig. 20, table 8). Eight of the 23 samples had ${ }^{3} \mathrm{H}$ concentrations greater than $1 \mathrm{TU}$ (sites Q4, Q7, Q15, Q17, Q23, Q27, Q28, and Q43). ${ }^{4} \mathrm{He}$ screening results indicated that the samples from all of these sites are potentially datable using the ${ }^{3} \mathrm{H} /{ }^{3} \mathrm{He}$ method. Thus, based on the ${ }^{3} \mathrm{H}$ and ${ }^{4} \mathrm{He}$ concentrations, at least some component of the groundwater collected at these sites is likely post-bomb recharge. The low ${ }^{3} \mathrm{H}$ concentrations measured in the majority of collected samples (15 out of 23) indicate that groundwater in the study area likely is predominantly pre-bomb recharge.

\section{Organic Compounds and Nutrients}

Organic compound (pesticide and herbicide) and nutrient concentrations in groundwater in the study area are potential indicators of surface-water infiltration and anthropogenic influences on groundwater. Detectable concentrations of organic compounds in a groundwater sample likely result from infiltration of rain or irrigation water following the surface application of pesticides and herbicides. Nutrient concentrations in groundwater (predominantly in the form 


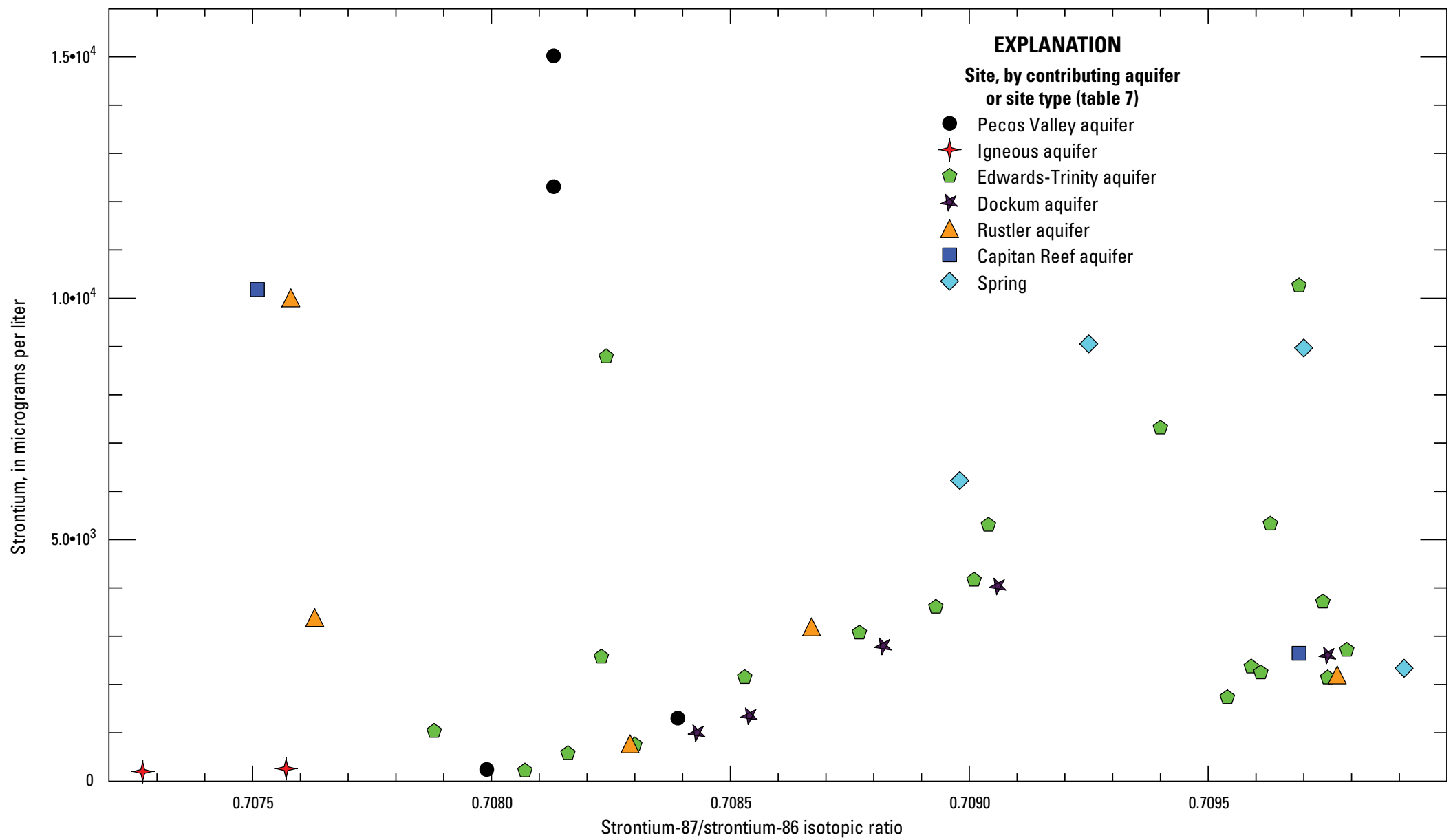

Figure 25. Relation between strontrium-87/strontium-86 isotopic ratio and strontium concentration for groundwater and spring samples collected in the Pecos County region study area, Texas. 


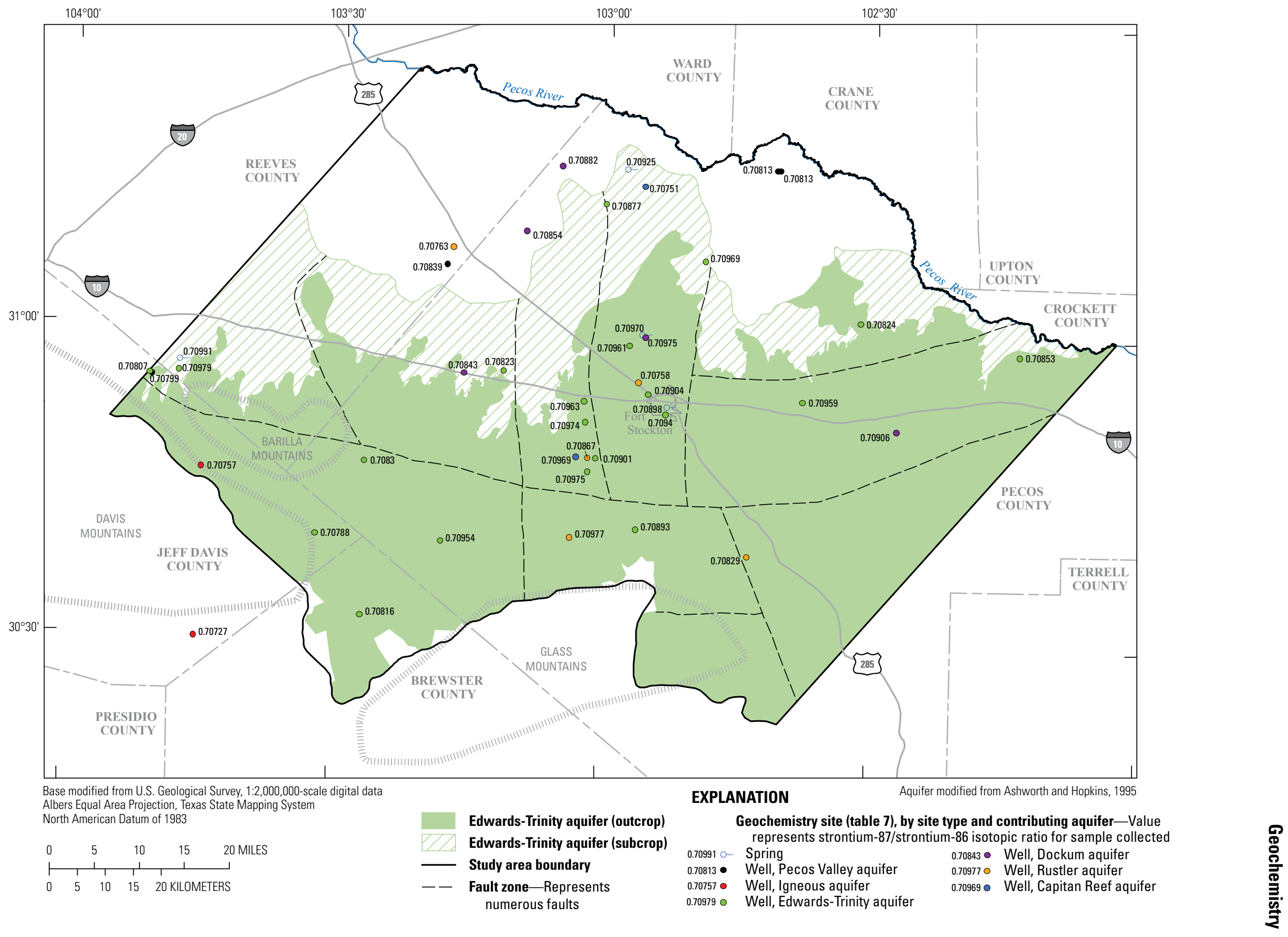

Figure 26. Strontium-87/strontium-86 isotopic ratios for samples collected from groundwater and spring sites in the Pecos County region study area, Texas. 
of nitrate and nitrite) that are higher than the prevailing background concentration might result in agricultural or municipal areas as a result of input from livestock manure, septic systems, municipal treatment systems, or fertilizers. National background concentrations of nitrate in groundwater have been estimated to be $1.0 \mathrm{mg} / \mathrm{L}$ (Dubrovsky and others, 2010). Land-cover data obtained from the National Land Cover Dataset (NLCD) 2006 (Fry and others, 2011) show the distribution of land cover in the study area (fig. 27). Because of the small amount of developed areas and the presence of agricultural areas (shown as cultivated crops), the combined concentrations of nitrate and nitrite $\left(\mathrm{NO}_{3}+\mathrm{NO}_{2}\right)$ were used to evaluate the potential presence of excess nutrients from irrigation, specifically cultivated crops, in the groundwater system.

Eight groundwater samples from the Igneous, EdwardsTrinity, and Dockum aquifers and two spring samples were analyzed for organic compounds, specifically pesticides and herbicides (table 7). Atrazine, a widely used herbicide, was detected in one sample collected from the EdwardsTrinity aquifer (site Q26) and one spring (site Q4). CIAT (deethylatrazine), an atrazine degradate, was detected in samples from three wells completed in the Edwards-Trinity aquifer (sites Q18, Q24, and Q26) and two springs (sites Q4 and Q6). The four deethylatrazine detections were qualified as estimated ("E") by the USGS National Water Quality Laboratory under laboratory reporting conventions used during the study period (Zaugg and others, 1995); a remark code of "E" indicates that a compound was identified at an estimated concentration, but concentration could not be accurately quantified. As explained in Oden and others (2011, p. 9), a constituent concentration is considered estimated by the laboratory when results are greater than the longterm method detection level and less than the laboratory reporting level. Deethylatrazine is permanently coded "E" because of poor laboratory recoveries. Sites with detectable concentrations (fig. 20) are in the Leon-Belding and Fort Stockton areas (fig. 1).

$\mathrm{NO}_{3}+\mathrm{NO}_{2}$ concentrations (as $\mathrm{N}$ ) ranged from not detected $(<0.02)$ to $6.67 \mathrm{mg} / \mathrm{L}$. Concentrations greater than $1 \mathrm{mg} / \mathrm{L}$ (table 7) were measured in samples collected from two wells completed in the Pecos Valley aquifer (sites Q27 and Q43). Concentrations of $\mathrm{NO}_{3}+\mathrm{NO}_{2}$ in samples collected from the two wells completed in the Igneous aquifer (sites Q7 and Q15) were less than $1 \mathrm{mg} / \mathrm{L} . \mathrm{NO}_{3}+\mathrm{NO}_{2}$ concentrations were greater than $1 \mathrm{mg} / \mathrm{L}$ in 8 out of 20 samples collected from wells completed in the Edwards-Trinity aquifer. These sites include Q18, Q24, and Q26, which were also sites for which the samples contained detectable atrazine or deethylatrazine. $\mathrm{NO}_{3}+\mathrm{NO}_{2}$ concentrations were greater than $1 \mathrm{mg} / \mathrm{L}$ in three of the five samples collected from wells completed in the Dockum aquifer (sites Q21, Q39, and Q44) (fig. 20). $\mathrm{NO}_{3}+\mathrm{NO}_{2}$ concentrations were greater than $1 \mathrm{mg} / \mathrm{L}$ in only one of the five samples collected from wells completed in the Rustler aquifer (site Q10) and in none of the samples collected from wells completed in the Capitan Reef aquifer. $\mathrm{NO}_{3}+\mathrm{NO}_{2}$ concentrations were greater than $1 \mathrm{mg} / \mathrm{L}$ in samples collected from Santa Rosa, Comanche, and Diamond Y springs (sites Q2, Q4, and Q6, respectively). It is possible that the elevated $\mathrm{NO}_{3}+\mathrm{NO}_{2}$ concentrations measured in samples collected from Santa Rosa and Diamond Y springs (2.95 and $6.67 \mathrm{mg} / \mathrm{L}$, respectively) reflect groundwater discharge, but it is also possible that edge-of-field surface runoff from land adjacent to the pools that occur where each spring discharges is the source of the elevated concentrations. Additionally, $\mathrm{NO}_{3}+\mathrm{NO}_{2}$ concentrations might also be affected by processes within the aquifers. While most groundwater samples were oxic (table 7), denitrification might be influencing $\mathrm{NO}_{3}+\mathrm{NO}_{2}$ concentrations in samples with low (less than $0.5 \mathrm{mg} / \mathrm{L}$ ) dissolved oxygen concentrations.

\section{Geochemical Endmembers}

Geochemical endmembers in the groundwater system were selected based on variations in geochemical composition in order to qualitatively evaluate groundwater-flow paths and mixing processes. Selected endmembers were: (1) regional groundwater flow in the Edwards-Trinity aquifer that originated as recharge northwest of the study area and enters the study area near the western corner, (2) recharge entering the groundwater system along the southern boundary of the study area from the Barilla and Davis Mountains, (3) recharge entering the groundwater system at the southern studyarea boundary from the Glass Mountains, and (4) regional groundwater flow in the Edwards-Trinity aquifer east of the Monument Draw trough. Although not denoted for the purposes of this report as geochemical endmembers, groundwater from the Dockum and Rustler aquifers likely mix with and affect groundwater compositions of the EdwardsTrinity aquifer.

The composition of the sample collected from site Q30 (fig. 20, tables 7 and 8), which is a well completed in the Edwards-Trinity aquifer in the western corner of the study area, was used to represent endmember 1: regional groundwater flow in the Edwards-Trinity aquifer entering the study area from the northwest. Endmember 1 was a Na-Ca$\mathrm{Cl}-\mathrm{SO}_{4}$ type water; specific conductance was $2,710 \mu \mathrm{S} / \mathrm{cm}$; $\mathrm{SO}_{4}$ concentration was $498 \mathrm{mg} / \mathrm{L} ; \mathrm{Cl}$ concentration was 473 $\mathrm{mg} / \mathrm{L} ; \delta^{18} \mathrm{O}$ and $\delta \mathrm{D}$ values were -8.34 and -57.7 per mil, respectively; ${ }^{87} \mathrm{Sr} /{ }^{86} \mathrm{Sr}$ ratio was 0.70979 ; tritium concentration was $0.25 \mathrm{TU}$; no organic compounds were detected; and $\mathrm{NO}_{3}+\mathrm{NO}_{2}$ concentration was $0.135 \mathrm{mg} / \mathrm{L}$. In summary, endmember 1 represents relatively mineralized, old water that likely recharged northwest of the study area under different climatic conditions and is flowing through the Edwards-Trinity aquifer along regional groundwater-flow paths.

Recharge along the southern boundary of the study area occurs as runoff from the mountains and moves vertically downward through underlying rocks and into the gravels along the slopes of the mountains (fig. 2) (Armstrong and McMillion, 1961; Small and Ozuna, 1993; Bochici, 1997; Uliana and Sharp, 2001; Uliana and others, 2007). There are 


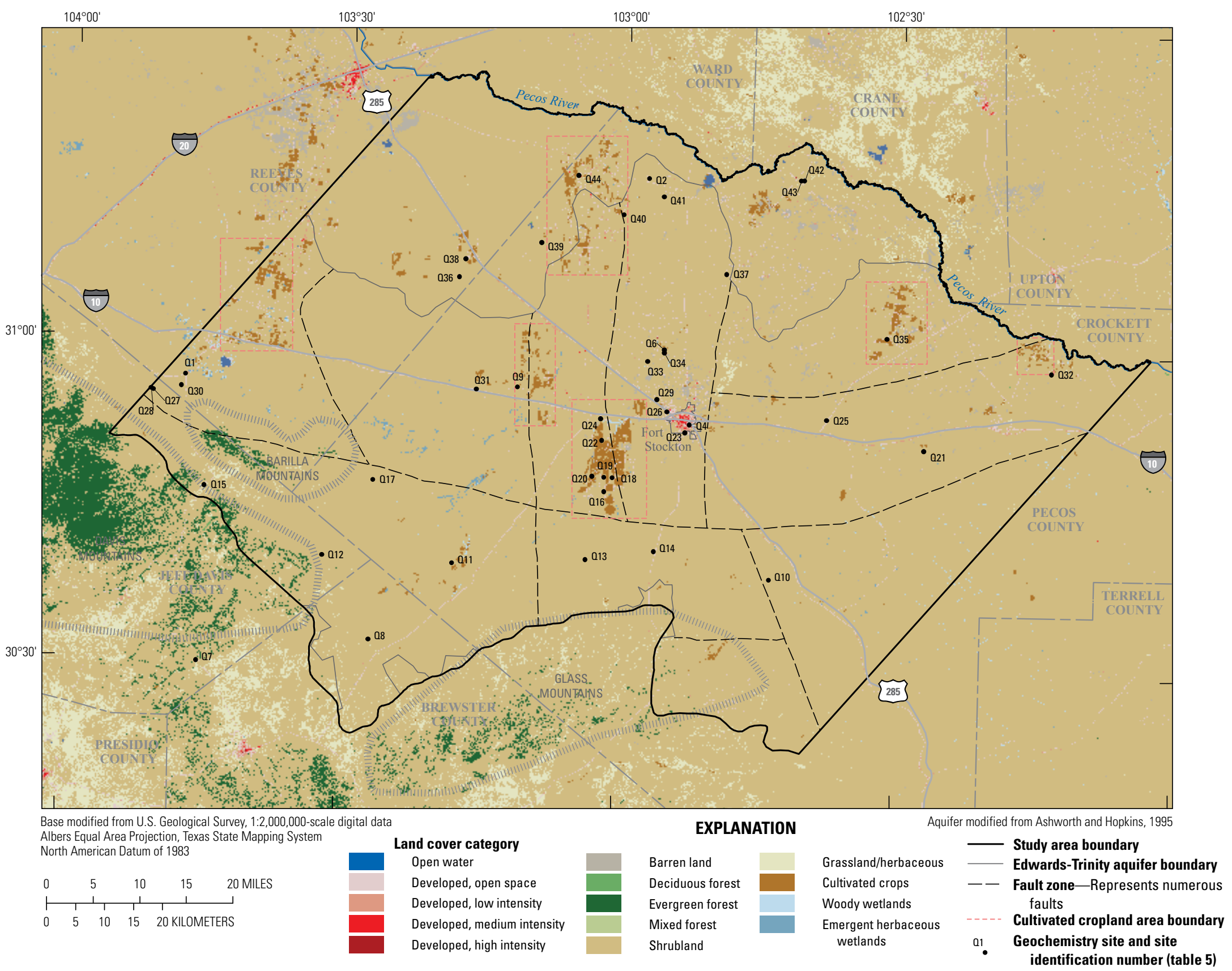


two distinct mountain-recharge endmembers because the Barilla and Davis Mountains are primarily igneous rocks composed of silicate minerals (endmember 2) and the Glass Mountains are sedimentary rocks composed primarily of carbonate minerals (endmember 3). Water-rock interaction with these different rock types results in different recharge compositions. The composition of the sample collected from site Q7 (fig. 20, tables 7 and 8), which is a well completed in the Igneous aquifer southwest of the study area, was used to represent endmember 2. Endmember 2 was a $\mathrm{Ca}-\mathrm{Na}-$ $\mathrm{HCO}_{3}$ type water; specific conductance was $408 \mu \mathrm{S} / \mathrm{cm} ; \mathrm{SO}_{4}$ concentration was $12.9 \mathrm{mg} / \mathrm{L} ; \mathrm{Cl}$ concentration was 8.39 $\mathrm{mg} / \mathrm{L} ; \delta^{18} \mathrm{O}$ and $\delta \mathrm{D}$ values were -6.23 and -41.6 per mil, respectively; ${ }^{87} \mathrm{Sr} /{ }^{86} \mathrm{Sr}$ ratio was 0.70727 , which was the lowest value measured in this study; the tritium concentration was $1.2 \mathrm{TU}$; organic compounds were not analyzed; and $\mathrm{NO}_{3}+\mathrm{NO}_{2}$ concentration was $0.632 \mathrm{mg} / \mathrm{L}$. Si concentrations (table 7) also provided insight into this endmember. Si concentrations would likely be higher in groundwater interacting with igneous rocks of the Barilla and Davis Mountains. Relatively higher Si concentrations for samples collected from the Igneous aquifer and wells completed in proximity to the Barilla and Davis Mountains are consistent with this hypothesis. The Si concentration at site Q7 was $43.6 \mathrm{mg} / \mathrm{L}$. In summary, endmember 2 represents relatively dilute, recent recharge with a relatively high concentration of $\mathrm{Si}$ and a $10{ }^{87} \mathrm{Sr} /{ }^{86} \mathrm{Sr}$ value that are indicative of interaction with $10{ }^{87} \mathrm{Sr} /{ }^{86} \mathrm{Sr}$ igneous rocks. Finally, the composition of endmember 2 is consistent with values reported by Uliana and others (2007) for samples collected in the Barilla and Davis Mountains, which were represented by their endmember B.

The composition of the sample collected from site Q8 (fig. 20 and table 7), which is a well completed in the Edwards-Trinity aquifer near the southwest boundary of the study area, was used to represent endmember 3; that is, recharge from the Glass Mountains. Endmember 3 was a type $\mathrm{Na}-\mathrm{HCO}_{3}$ water; specific conductance was 587 $\mu \mathrm{S} / \mathrm{cm} ; \mathrm{SO}_{4}$ concentration was $56.0 \mathrm{mg} / \mathrm{L} ; \mathrm{Cl}$ concentrations was $15.9 \mathrm{mg} / \mathrm{L} ; \delta^{18} \mathrm{O}$ was -7.16 per mil and $\delta \mathrm{D}$ was -49.0 per mil, (predominantly young water); ${ }^{87} \mathrm{Sr} r{ }^{86} \mathrm{Sr}$ was 0.70816; environmental tracers and organic compounds were not analyzed; and $\mathrm{NO}_{3}+\mathrm{NO}_{2}$ was not detected. The $\mathrm{Si}$ concentration was $14.3 \mathrm{mg} / \mathrm{L}$, which is lower than the $\mathrm{Si}$ concentration of endmember 2 as well as the average value of $21.6 \mathrm{mg} / \mathrm{L}$ for Edwards-Trinity aquifer water. From the geochemical assessment, endmember 3 represents relatively dilute, recent recharge with a composition indicative of interaction with carbonate rocks.

The composition of the sample collected from site Q25 (fig. 20, tables 7 and 8), which is a well completed in the Edwards-Trinity aquifer in the eastern part of the study area, was used to represent endmember 4; that is, regional groundwater flow in the Edwards-Trinity aquifer east of the Monument Draw trough. Endmember 4 was a type Na$\mathrm{Ca}-\mathrm{Mg}-\mathrm{SO}_{4}-\mathrm{Cl}-\mathrm{HCO}_{3}$ water; specific conductance was $1,520 \mu \mathrm{S} / \mathrm{cm} ; \mathrm{SO}_{4}$ concentration was $277 \mathrm{mg} / \mathrm{L} ; \mathrm{Cl}$ concentration was $203 \mathrm{mg} / \mathrm{L} ; \delta^{18} \mathrm{O}$ was -7.47 per mil and $\delta$ D was -49.6 per mil; ${ }^{87} \mathrm{Sr} /{ }^{86} \mathrm{Sr}$ ratio was 0.70959 ; tritium concentration was $0.09 \mathrm{TU}$; and organic compounds and $\mathrm{NO}_{3}+\mathrm{NO}_{2}$ were not detected. Endmember 4 represents relatively mineralized water that is likely a mixture of recharge under current and different climatic conditions and is flowing through the Edwards-Trinity aquifer along regional groundwater-flow paths.

\section{Groundwater-Flow System}

Geochemical and groundwater-level data were used in context with the hydrogeologic framework to assess regional groundwater-flow paths, recharge sources, and groundwater mixing and discharge in the study area. Pearson and others (2012) detail the methods used for collection, analysis, and quality control of the groundwater-level data used in this report. The geochemical characteristics and endmembers were used to qualitatively evaluate the mixing of waters from different sources and the flow-path evolution of the chemical characteristics of aquifer water. Groundwater-level data were used to create potentiometric-surface maps of the EdwardsTrinity aquifer, assess regional groundwater gradients, and compute vertical gradients between the Edwards-Trinity and underlying aquifers. Structural features such as bed orientation and thickness, mountains, troughs, and faults play a substantial role in the distribution of recharge, local and regional groundwater-flow paths, spring discharge, and aquifer interaction.

Groundwater-level altitudes and geologic data for the study area were compiled from NWIS (U.S. Geological Survey, 2011), the TWDB Groundwater Database (Texas Water Development Board, 2011), and Middle Pecos Groundwater Conservation District (Paul Weatherby, Middle Pecos Groundwater Conservation District, written commun., 2011). A set of three criteria were used to determine which wells were completed in the Edwards-Trinity aquifer. Wells were considered completed in the Edwards-Trinity aquifer if:

1. the total depth was deeper than the top of the Cretaceousage rocks,

2. the top of openings (screen, slots, open hole) in the well had a depth deeper than the top of the Cretaceous-age rocks, and

3. the total depth of the well was less than $50 \mathrm{ft}$ below the base of the Cretaceous-age rocks.

If there were no opening or total-depth data associated with a well, the agency-assigned geologic data were used to identify the aquifer in which the well was screened so that groundwater-level measurements could be related to the specific aquifer in which the well was completed. Wells completed in multiple aquifers were not used in the groundwater-level analysis. All groundwater-level data 
collected from the Edwards-Trinity aquifer were separated into two seasons (summer and winter) for predevelopment years (before 1950) and for each year from 1950 to 2011. The summer season was defined as the months from May through October, and the winter season was defined as the months from November through April. These seasons were chosen as 6-month periods that coincide roughly with the start and the end of the agricultural irrigation season. The winter-season measurements were used for groundwaterflow analysis because groundwater-level data collected during these months are less affected by irrigation pumping. Figure 28 shows a potentiometric-surface map using the average of the groundwater-level data collected at each well completed in the Edwards-Trinity aquifer for the winter months during 1980-2010 (table 9 at end of report). The potentiometric-surface grid was generated using minimum curvature interpolation techniques. Geosoft, Inc. (2012) describes the minimum-curvature methods used for grid generation.

\section{Regional Groundwater Flow}

Groundwater-level altitudes in the Edwards-Trinity aquifer generally decrease from southwest to northeast and regional groundwater flow is from the south and southwest to the north and northeast in the study area (fig. 28). The highest groundwater-level altitudes (more than 3,300 ft) were measured near the southwestern boundary of the study area. Some of the lowest groundwater-level altitudes (about 2,400 ft) were measured in the down-dip extent of the Edwards-Trinity aquifer in the Monument Draw trough; a few groundwater altitudes of less than $2,300 \mathrm{ft}$ were measured near the eastern part of the study area.

Two groundwater divides were observed in the study area from the potentiometric surface of the Edwards-Trinity aquifer (fig. 28). A groundwater divide begins where the boundaries of Jeff Davis, Brewster, and Pecos Counties come together, then extends generally northwest to the ReevesPecos County boundary. Groundwater west of this divide flows from the Barilla and Davis Mountains to the down-dip sections of the Edwards-Trinity along the northwestern studyarea boundary into the Pecos trough (fig. 2). Groundwater east of this divide flows along the western margin of the Monument Draw trough. The other groundwater divide trends along the center of Monument Draw trough and is potentially related to the upwelling of water from deeper units. Groundwater west of the divide predominantly flows from the Glass Mountains to the down-dip section of Monument Draw trough, and groundwater east of the divide flows from the Glass Mountains into the down-dip section of Monument Draw trough and the eastern part of the study area. Because the potentiometric-surface map was developed using the average of the groundwater-level data collected in winter months, the locations of the divides likely vary during the irrigation season when groundwater pumping increases.

\section{Recharge}

Integrated results of this and previous studies indicate the Edwards-Trinity aquifer is recharged by: (1) regional groundwater flow in the Edwards-Trinity aquifer entering the study area from the northwest; (2) runoff from the Barilla, Davis, and Glass Mountains that percolates through underlying rocks and into the gravels along the slopes of the mountains; (3) return flow from irrigation; and (4) upwelling from deeper aquifers. These sources of recharge were qualitatively evaluated for this report and are consistent with previously reported sources (Armstrong and McMillion, 1961; Hiss, 1976; Small and Ozuna, 1993; Boghici, 1997; Uliana and Sharp, 2001; Uliana and others, 2007; Daniel B. Stephens and Associates, 2010). Neither the absolute nor the relative recharge proportion from each potential source was estimated. Also, although a component of the groundwater appears to have recharged under conditions similar to the recent, local climate, the only samples collected from the Edwards-Trinity aquifer that likely recharged during about the past 60 years (post-bomb) were collected from wells in mountain recharge areas and in areas receiving agricultural return flow. These results are consistent with local climate data because substantial, recent recharge is unlikely given the discrepancy between an average annual rainfall of 14 inches (National Weather Service, 2011) and annual potential evapotranspiration rates of as much as 109 inches (Boghici, 1997).

Regional groundwater flow in the Edwards-Trinity aquifer that originated as recharge northwest of the study area enters the study area near the western boundary (fig. 28). This regional groundwater-flow path was previously documented by Uliana and Sharp (2001) and Uliana and others (2007). The potentiometric surface shows that the groundwater-level altitudes are highest in the western part of the study area (fig. 28), and regional groundwater flow is generally towards the north. The groundwater divide near the Pecos-Reeves County boundary likely limits the connection of this regional flow path with the rest of the study area. The groundwater composition is consistent with older (Pleistocene) mineralized groundwater with high ${ }^{87} \mathrm{Sr} /{ }^{86} \mathrm{Sr}$ values (site Q30; endmember 1).

Recharge to the Edwards-Trinity aquifer along the southern boundary of the study area occurs from the Barilla, Davis, and Glass Mountains (fig. 28) (Armstrong and McMillion, 1961; Small and Ozuna, 1993; Boghici, 1997; Uliana and Sharp, 2001; Uliana and others, 2007). The geochemical composition of this relatively dilute, recent recharge is characterized by low specific conductance and stable isotope values similar to local rainfall. Although the hydrochemical facies for recharge endmembers from the Barilla and Davis Mountains (site Q7; endmember 2) and the Glass Mountains (site Q8; endmember 3) are similar (Ca-Na-HCO 3 and $\mathrm{Na}-\mathrm{HCO}_{3}$, respectively) and low ${ }^{87} \mathrm{Sr} /{ }^{86} \mathrm{Sr}$ values $(0.70727$ and 0.70816 , respectively) are consistent 


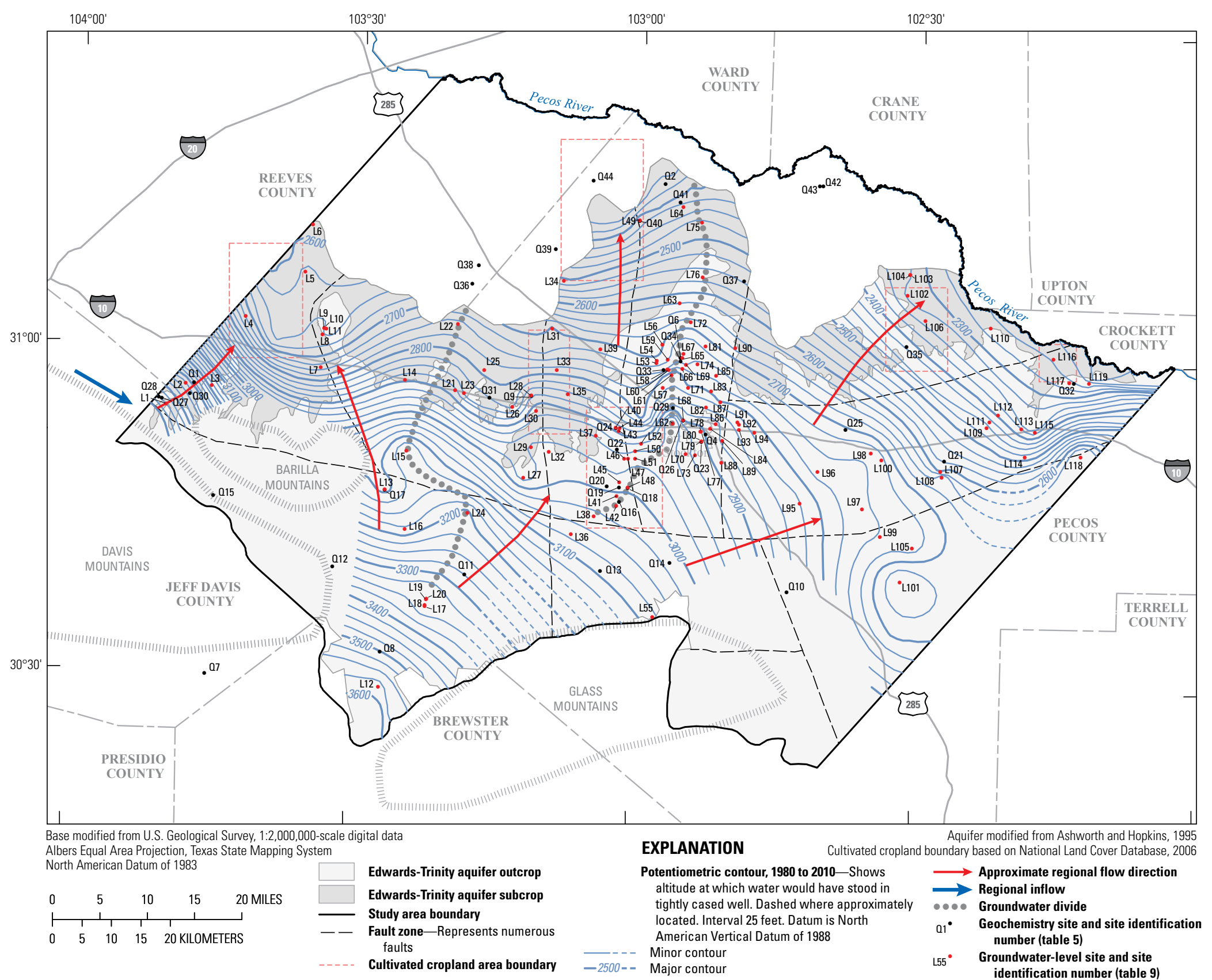

Figure 28. Potentiometric-surface map of the Edwards-Trinity aquifer developed using the average of the winter (November through April) groundwater-level data collected at each site for 1980-2010 in the Pecos County region study area, Texas. 
with interaction with igneous rocks or carbonate rocks and not with siliciclastic rocks with high ${ }^{87} \mathrm{Sr} /{ }^{86} \mathrm{Sr}$ values, $\mathrm{Si}$ concentrations ( 43.6 and $14.3 \mathrm{mg} / \mathrm{L}$ ) indicate these waters are likely from different sources. The composition of the Igneous aquifer sample from site Q15, the Pecos Valley aquifer sample collected from site Q27, and the Edwards-Trinity aquifer sample collected from site Q28 (fig. 28, tables 7 and 8) are similar to that of the Igneous aquifer recharge endmember 2 (high stable isotope values, low ${ }^{87} \mathrm{Sr} /{ }^{86} \mathrm{Sr}$ values, and high Si concentrations) and are west of the inferred groundwater divide. The high Si concentration and low ${ }^{87} \mathrm{Sr} /{ }^{86} \mathrm{Sr}$ values in groundwater samples from these wells are likely influenced by interaction with igneous rocks of the Barilla and Davis Mountains.

The results of this study indicate that return flows from irrigation likely contribute recharge to the EdwardsTrinity aquifer in agricultural areas (figs. 27 and 28). Detections of organic compounds (atrazine and its degradate deethylatrazine) and elevated $\mathrm{NO}_{3}+\mathrm{NO}_{2}$ in the Leon-Belding and down-gradient parts of the Edwards-Trinity aquifer, as well as near other agricultural areas, are consistent with a component of recharge from agricultural return flow (figs. 27 and 28, table 7). Generally, detections of organic compounds and elevated $\mathrm{NO}_{3}+\mathrm{NO}_{2}$ concentrations were measured in the shallowest aquifer units. For example, organic compounds and elevated $\mathrm{NO}_{3}+\mathrm{NO}_{2}$ concentrations were measured in the Edwards-Trinity aquifer in the Leon-Belding and downgradient areas but not in the underlying Rustler and Capitan Reef aquifers.

Upwelling of groundwater from deeper aquifers to the Edwards-Trinity aquifer has been previously documented (Hiss, 1976; Small and Ozuna, 1993; Barker and others, 1994). Upwelling is likely the result of groundwater flow from underlying aquifers along fault zones (Ashworth, 1990; Boghici, 1997) or, as hypothesized by Small and Ozuna (1993), it may occur in areas where a Triassic shale unit that separates the Trinity Group of the Edwards-Trinity aquifer from underlying units is absent. Upwelling groundwater contributes higher concentrations of salinity, including higher $\mathrm{SO}_{4}$ and $\mathrm{Cl}$ concentrations, to overlying units as a result of extensive interaction with Permian-age evaporite deposits. Faulted zones (figs. 2, 17, 18, and 28) in the Leon-Belding and Fort Stockton areas (fig. 1) are some areas where upwelling is likely occurring. The high-salinity water collected from the Edwards-Trinity aquifer (sites Q16, Q18, Q22, Q23, Q24, and Q26; specific conductance from 2,040 to 3,820 $\mu \mathrm{S} / \mathrm{cm}$ ) (fig. 28, table 7) and Comanche Springs (site Q4; specific conductance $3,570 \mu \mathrm{S} / \mathrm{cm}$ ), which discharges from the Edwards-Trinity aquifer, is compositionally similar to the high-salinity water collected from the underlying Rustler and Capitan Reef aquifers (sites Q19, Q20, and Q29; specific conductance 2,290 to 3,980 $\mu \mathrm{S} / \mathrm{cm}$ ). Groundwater-level data for the other aquifers in the groundwater system were limited. However, groundwater-level altitudes collected by the TWDB in 2001 from two wells completed in the Edwards-Trinity aquifer and in 2002 from two wells completed in the Rustler aquifer were used to evaluate vertical gradients in the LeonBelding area (fig. 2) (Edwards-Trinity site numbers L48 and L45 [fig. 28, table 9]; and TWDB Rustler site numbers 5216609 [site Q19; fig. 28, table 5] and 5216608 [less than 0.5 miles northeast of L57]; Texas Water Development Board, 2011). Groundwater altitudes of 3,060 and 3,076 ft in the Rustler wells (measured Jan. 2, 2002, at sites 5216609 and 5216608 , respectively) and 2,955 (measured May 9, 2001, at site L48) and 2,977 ft (measured April 2, 2001, at site L45) in the Edwards-Trinity wells show an upward gradient from the Rustler to the Edwards-Trinity aquifer of about 83 to $121 \mathrm{ft}$, which is consistent with the geochemical results and a historical upward gradient reported by Small and Ozuna (1993).

\section{Geochemical Mixing and Discharge}

Results of this study are consistent with previous studies of the region and indicate that groundwater generally flows north into the down-dip extent of the Edwards-Trinity aquifer or northeast out of the study area (fig. 28) (Barker and others, 1994; Anaya and Jones, 2009). Groundwater naturally discharges from the aquifer from springs, into overlying or underlying units at the down-dip extent of the aquifer, or to the Pecos River (Barker and others, 1994; Anaya and Jones, 2009). The four springs sampled in the study area (table 5) are likely connected to groundwater discharge along fault zones (figs. 17-18 and 28).

Regional groundwater flow entering the study area from the northwest naturally discharges from springs or turns northward to flow into the Pecos trough where it discharges into the Pecos Valley or Dockum aquifers at the down-dip extent of the Edwards-Trinity aquifer (Barker and others, 1994). The composition of samples collected from San Solomon Spring (site Q1; fig. 28, tables 7 and 8), which discharge from the Edwards-Trinity aquifer, are similar to those of the regional groundwater flow characterized by endmember 1 (site Q30). Previous studies indicate there are also local influences on San Solomon Spring (LaFave and Sharp, 1987; Sharp and others, 1999; Uliana and others, 2007).

Recharge from the Barilla and Davis Mountains also flows toward the Pecos trough and is thought to naturally discharge to other aquifers in the groundwater system (Barker and others, 1994). The Si concentrations in Edwards-Trinity aquifer samples from sites Q12 and Q17 (21.1 and $26.7 \mathrm{mg} / \mathrm{L}$, respectively), which are intermediate between the mountain recharge endmembers 2 and 3 concentrations of $43.6 \mathrm{mg} / \mathrm{L}$ and $14.3 \mathrm{mg} / \mathrm{L}$, indicated there might be mixing of recharge from the Barilla and Davis Mountains with recharge that has interacted with igneous rocks to a lesser degree than the igneous signature of endmember 2 . The potentiometricsurface map (fig. 28) shows that recharge from the Glass Mountains primarily flows to the Monument Draw trough (fig. 2) and to the east. The Si concentration in the sample collected from site Q11 (28.4 mg/L) indicated that there could 
be some mixing of recharge from the Glass Mountains and groundwater that has been in contact with silicate-rich igneous or siliciclastic rocks. The relatively high ${ }^{87} \mathrm{Sr} /{ }^{86} \mathrm{Sr}$ value (0.70954) in the sample collected from site Q11, however, was more consistent with a siliciclastic source than igneous rocks of the Barilla and Davis Mountains.

Groundwater flow in the Edwards-Trinity aquifer in the Monument Draw trough originated as recharge in the Glass Mountains, agricultural return flow, or upwelling groundwater from lower units. Groundwater generally flows north and northeast in the Monument Draw trough and naturally discharges from springs or to other aquifers in the groundwater system (Barker and others, 1994). Based on low stable isotope ratios, groundwater in the Edwards-Trinity, Rustler, and Capitan Reef aquifers in the Monument Draw trough probably originated as recharge during the wetter, cooler climates of the Pleistocene. Recent recharge to the Edwards-Trinity aquifer near the Glass Mountains in the Monument Draw trough area is hydrologically possible, but low stable isotope values of groundwater from site Q14 of $\delta^{18} \mathrm{O}-7.89$ per mil and $\delta \mathrm{D}-55.0$ per mil (fig. 28, table 7) and undetected ${ }^{3} \mathrm{H}$ (table 8) indicate the Edwards-Trinity aquifer water in this area is predominantly old. Similarly, high specific conductance, $\mathrm{SO}_{4}$ concentrations, and $\mathrm{Cl}$ concentrations, and similar $\delta^{18} \mathrm{O}, \delta \mathrm{D}$, and ${ }^{87} \mathrm{Sr} /{ }^{86} \mathrm{Sr}$ values in groundwater samples collected from wells completed in the Monument Draw trough roughly south of Interstate Highway 10 (I-10) (fig. 28, tables 7 and 8) support earlier findings that groundwater from the Capitan Reef aquifer is mixing with groundwater flowing through Permian-age evaporite deposits in the Rustler aquifer (Small and Ozuna, 1993). Groundwater discharge from Comanche Springs (Q4) has a similar composition to groundwater samples collected from wells in this area (fig. 28, tables 7 and 8), including the detection of organic compounds and elevated $\mathrm{NO}_{3}+\mathrm{NO}_{2}$ concentrations that were measured in samples from upgradient Edwards-Trinity aquifer sites. This compositional similarity, along with the absence of flow at the springs caused by the lowering of the water table from pumping during the irrigation season (Small and Ozuna, 1993), confirms the connection between the springs, upgradient Edwards-Trinity groundwater, and return flow from the Leon-Belding area.

Except in isolated areas, a clear connection between the Edwards-Trinity aquifer and the underlying Rustler is not apparent in the Monument Draw trough north of I-10 (figs. 3 and 4). Upwelling in this area might be inhibited by the shale and siltstone confining units in the Lower Dockum Group (table 1; Barker and others, 1994), or these wells might not intersect faults or other structural features that act as preferential vertical flow paths. Samples collected from sites Q33 and Q40 (fig. 28, table 7), which are wells completed in the Edwards-Trinity aquifer where it overlies, or is near the edge of, the estimated extent of the Dockum aquifer, have somewhat different compositions than groundwater from samples collected from wells in the Monument Draw trough roughly south of I-10. However, samples from the well at site
Q37 and Diamond Y and Santa Rosa Springs (sites Q6 and Q2) (fig. 28, tables 7 and 8), both of which discharge from the Edwards-Trinity aquifer, are compositionally similar to wells in the Monument Draw trough south of I-10. Site Q37 is on the eastern side of Monument Draw trough, completed in a portion of the Edwards-Trinity aquifer that is likely not underlain by the Dockum aquifer; Diamond Y Spring are east of the estimated extent of the Dockum aquifer; and Santa Rosa Springs appear to be the result of a localized upwelling that is not affected by the presence of the Dockum aquifer. Diamond $\mathrm{Y}$ and Santa Rosa Springs are within fault zones (figs.

17-18 and 28) (Baumgardner and others, 1982; Veni, 1991; Boghici, 1997) that create preferential flow paths for lower aquifers to discharge to the surface. Finally, groundwater likely discharges from the down-dip extent of the EdwardsTrinity aquifer in the Monument Draw trough to overlying or underlying aquifer units (Barker and others, 1994).

Groundwater in the eastern part of the study area likely originates in the Glass Mountains, generally flows northeast, and flows out of the study area to the east or naturally discharges from springs to other aquifers in the groundwater system or to the Pecos River. Groundwater in the eastern part of the study area has little compositional similarity to the groundwater samples collected in the Monument Draw trough area. The composition of groundwater collected from Edwards-Trinity aquifer site Q25 (endmember 4) (fig. 28, tables 7 and 8) is representative of regional groundwater flow in the Edwards-Trinity aquifer east of the Monument Draw trough. This endmember and the groundwater collected from the Edwards-Trinity aquifer site Q32 are more compositionally similar in terms of salinity to the groundwater collected from Edwards-Trinity aquifer sites Q8 and Q11, which are west of the Monument Draw trough near the Glass Mountains, than to groundwater samples collected in the Monument Draw trough area even though the regional gradient appears to move groundwater through the trough into the east. Conversely, the ${ }^{87} \mathrm{Sr} /{ }^{86} \mathrm{Sr}$ and stable isotope values of groundwater collected from sites Q25 and Q32 are different. The ${ }^{87} \mathrm{Sr}{ }^{86} \mathrm{Sr}$ value of groundwater collected from site Q25 was 0.70959 and $\delta^{18} \mathrm{O}$ was -7.47 per mil, which are similar to values measured in groundwater samples collected in the Monument Draw trough area and are consistent with a mixture of young and old groundwater interacting with siliciclastic rocks. The ${ }^{87} \mathrm{Sr} /{ }^{86} \mathrm{Sr}$ and $\delta^{18} \mathrm{O}$ values in groundwater collected from site Q32 were 0.70853 and -6.75 per mil, respectively, which were more similar to the values measured in groundwater collected from site Q35 (0.70824 and -7.24) than site Q25 and are consistent with relatively young water interacting with Cretaceous-age carbonate rocks. Conversely, the groundwater collected from sites Q32 and Q35 are compositionally dissimilar in every other way. These compositional inconsistencies support the theory that there are localized influences on groundwater chemistry and regional groundwater flow. 


\section{Summary}

The U.S. Geological Survey (USGS), in cooperation with the Middle Pecos Groundwater Conservation District, Pecos County, City of Fort Stockton, Brewster County, and Pecos County Water Control and Improvement District No. 1, conducted a comprehensive, integrated analysis of available hydrogeologic data in order to develop a conceptual model of the Edwards-Trinity and related aquifers in the Pecos County region study area in west Texas. The conceptual model of the hydrogeologic framework, geochemistry, and groundwaterflow system in the 4,700 square-mile study area was developed in an effort to better understand the groundwater system and establish a scientific foundation for resourcemanagement decisions. Development of the conceptual model is the second phase of a three-phase groundwater-availability study being conducted in the Pecos County region by the USGS and the cooperators. The first phase was to collect groundwater, surface-water, geochemical, geophysical, and geologic data in the study area and develop a geodatabase of historical and collected data. Data compiled in the first phase of the study were used in this report to develop the conceptual model. The third phase of the study involves a numerical groundwater-flow model of the Edwards-Trinity aquifer in order to simulate groundwater conditions based on various groundwater-withdrawal scenarios.

Analysis of well, geophysical, geochemical, and hydrologic data contributed to the development of the conceptual model. Lithologic information obtained from well reports and geophysical data were used to describe the hydrostratigraphy and structural features of the groundwater system and aquifer-test data were used to estimate aquifer hydraulic properties. Geochemical data were used to evaluate groundwater-flow paths, water-rock interaction, aquifer interaction, and the mixing of water from different sources. Groundwater-level data also were used to evaluate aquifer interaction as well as to develop a potentiometric-surface map, delineate regional groundwater divides, and describe regional groundwater-flow paths.

Subsurface data were obtained from well reports; natural gamma, electric, and electromagnetic induction borehole geophysical logs; and audio-magnetotelluric soundings. The subsurface data were analyzed in order to map the top and base of the Edwards-Trinity aquifer, the top of the Trinity Group of the Edwards-Trinity aquifer, and the lateral and vertical relations of overlying and underlying aquifers where they occur in order to develop the hydrostratigraphy of the study area and evaluate structural features.

The thickness of the Edwards-Trinity aquifer in the study area was calculated as the difference in altitudes between the top and the base of the Edwards-Trinity aquifer. About 50 percent of the aquifer was between 234 and $362 \mathrm{ft}$ thick with a minimum of about $5 \mathrm{ft}$ and maximum of about $797 \mathrm{ft}$. Some of the thinnest sections of the Edwards-Trinity aquifer were in the eastern part of the study area, near the northwestern slope of the Glass Mountains, and near the northeastern slope of the Davis Mountains. Some of the thickest sections of the
Edwards-Trinity aquifer were in the Pecos, Monument Draw, and Belding-Coyanosa trough areas.

Normal-fault zones were delineated based on interpretations of cross sections of the top and base surfaces of the Edwards-Trinity aquifer units. Faults appear to have formed as growth and collapse features as sediments were deposited along the margins of more resistant rocks and structures, such as the Glass Mountains, and as overlying sediments collapsed into the voids created by the dissolution of Permianage evaporite deposits. Fault zones delineate domains in the hydrogeologic framework that generally align with previously identified structural features such as the Pecos and Monument Draw troughs.

Transmissivity values calculated and estimated from historical aquifer-test data ranged from 1,500 to $1,216,000$ gallons per day per foot. The highest transmissivity values were measured in the Monument Draw trough area, which is also one of the thickest parts of the Edwards-Trinity aquifer and is in a faulted area. The lowest values were measured in the eastern part of the study, near some of the thinnest parts of the aquifer. Hydraulic conductivity values generally showed the same trends as the transmissivity values.

Analysis of the geochemical samples provided insight into the chemical characteristics of water from different sources and different aquifers. Chemical characteristics of water from different sources were used to qualitatively evaluate aquifer interaction, groundwater-flow paths, water-rock interaction, and mixing of water from different sources and to identify likely source waters and geochemical endmembers. Useful geochemical properties included specific conductance, hydrochemical facies, sulfate and chloride concentrations, silica concentrations, oxygen and hydrogen stable isotopes, strontium isotopes, environmental tracers, and concentrations of organic compounds and nutrients. The qualitative geochemical analysis did not include a quantitative evaluation of residence times in the aquifer nor did it include geochemical flow-path modeling of the groundwater system.

Geochemical and isotopic results indicate groundwater in the system likely is dominated by mineralized, regional groundwater flow that probably recharged during the cooler, wetter climates of the Pleistocene with variable contributions of recent, local recharge. The mixing of water from multiple sources combined with water-rock interaction with various rock types, including siliciclastic, carbonate, evaporite, and igneous rocks, contributed to a groundwater chemistry that was complex between and within aquifer units.

Four endmembers were identified to use as part of the qualitative groundwater-flow and mixing analysis. The endmembers represented: (1) mineralized groundwater that likely recharged northwest of the study area during the Pleistocene and is flowing through the Edwards-Trinity aquifer along regional groundwater-flow paths; (2) dilute, recent recharge from the Barilla and Davis Mountains with a composition indicative of interaction with igneous rocks; (3) dilute, recent recharge from the Glass Mountains with a composition indicative of interaction with carbonate rocks; and (4) mineralized water that is likely a mixture of recharge 
under recent and Pleistocene climatic conditions and is flowing through the Edwards-Trinity aquifer along regional groundwater-flow paths east of the Monument Draw trough.

Groundwater-level and geochemical data were used in context with the hydrogeologic framework to assess regional groundwater-flow paths, recharge sources, and groundwater mixing and discharge in the study area. The geochemical characteristics and endmembers were used to qualitatively evaluate the mixing of water from different sources and the flow-path evolution of the chemical characteristics of aquifer water. Historical and current groundwater-level data were used to create a potentiometric-surface map of the EdwardsTrinity aquifer, assess regional groundwater gradients, and compute vertical gradients between the Edwards-Trinity and underlying aquifers. Structural features such as bed orientation and thickness, mountains, troughs, and faults play a substantial role in the distribution of recharge, local and regional groundwater-flow paths, spring discharge, and aquifer interaction.

Groundwater-level altitudes used to generate the potentiometric-surface map of the Edwards-Trinity aquifer ranged from about 2,300 to about $3,300 \mathrm{ft}$ and generally decreased from southwest to northeast. Regional groundwater flow is from areas of recharge in the south and southwest to the north and northeast. Four principal sources of recharge to the Edwards-Trinity aquifer were identified: (1) regional groundwater flow in the Edwards-Trinity aquifer that originated as recharge northwest of the study area and enters the study area near the western corner; (2) runoff from the Barilla, Davis, and Glass Mountains that percolates through underlying rocks and into the gravels along the slopes of the mountains; (3) return flow from irrigation; and (4) upwelling from deeper aquifers. Although some of the groundwater appears to have recharged under conditions similar to the current climate, the only samples collected from the EdwardsTrinity aquifer that likely recharged during the last 60 years (post-bomb) were collected from wells in mountain recharge areas and in areas receiving agricultural return flow.

Groundwater generally flows north into the down-dip extent of the Edwards-Trinity aquifer or east out of the study area. Regional groundwater flow entering the study area from the northwest naturally discharges from springs or turns northward to flow into the Pecos trough where it discharges into the Pecos Valley or Dockum aquifers at the down-dip extent of the Edwards-Trinity aquifer. Recharge from the Barilla and Davis Mountains also predominantly flows toward the Pecos trough and most likely naturally discharges to other aquifers in the groundwater system. Groundwater flow in the Edwards-Trinity aquifer in the Monument Draw trough originated as recharge in the Glass Mountains, agricultural return flow, or upwelling groundwater from lower units. Edwards-Trinity aquifer water generally flows north and northeast in the Monument Draw trough and naturally discharges from springs or to other aquifers in the groundwater system at the down-dip extent. Groundwater in the eastern part of the study area likely originated in the Glass Mountains, generally flows northeast, and flows out of the study area to the east or naturally discharges from springs to other aquifers in the groundwater system at the down-dip extent or to the Pecos River.

\section{References Cited}

Anaya, Roberto, and Jones, Ian, 2009, Groundwater availability model for the Edwards-Trinity (Plateau) and Pecos Valley aquifers of Texas: Texas Water Development Board Report 373, 103 p.

Armstrong, C.A., and McMillion, L.G., 1961, Geology and ground-water resources of Pecos County, Texas: Texas Board of Water Engineers Bulletin 6106, 536 p.

Ashworth, J.B., 1990, Evaluation of ground-water resources in parts of Loving, Pecos, Reeves, Ward, and Winkler Counties, Texas: Texas Water Development Board Report 317, 51 p.

Ashworth, J.B., and Hopkins, Janie, 1995, Aquifers of Texas: Texas Water Development Board Report 345, 69 p.

Banner, J.L., 2004, Radiogenic isotopes-Systematics and applications to earth surface processes and chemical stratigraphy: Earth Science Reviews, v. 65, p. 141-194.

Banner, J.L., and Kaufman, Jonathan, 1994, The isotopic record of ocean chemistry and diagenesis preserved in nonluminescent brachiopods from Mississippian carbonate rocks, Illinois and Missouri: Geological Society of America Bulletin, v. 106, p. 1074-1082.

Banner, J.L., Musgrove, MaryLynn, and Capo, R.C., 1994, Tracing groundwater evolution in a limestone aquifer using $\mathrm{Sr}$ isotopes - Effects of multiple sources of dissolved ions and mineral-solution reactions: Geology, v. 22, p. 687-690.

Barker, R.A., and Ardis, A.F., 1992, Configuration of the base of the Edwards-Trinity aquifer and hydrogeology of the underlying pre-Cretaceous rocks, west-central Texas: U.S. Geological Survey Water-Resources Investigations Report 91-4071, 25 p., 1 pl.

Barker, R.A., and Ardis, A.F., 1996, Hydrogeological framework of the Edwards-Trinity aquifer system, westcentral Texas: U.S. Geological Survey Professional Paper 1421-B, p. B1-B61.

Barker, R.A., Bush, P.W., and Baker, E.T., Jr., 1994, Geologic history and hydrogeologic setting of the Edwards-Trinity aquifer system, west-central Texas: U.S. Geological Survey Water-Resources Investigations Report 94-4039, 48 p.

Baumgardner, R.W., Jr., Hoadley, A.D., and Goldstein, A.G., 1982, Formation of the Wink Sink, a salt dissolution and collapse feature, Winkler County, Texas: Bureau of Economic Geology Report of Investigations no. 114, 38 p. 
Bradley, R.G., and Kalaswad, Sanjeev, 2003, The groundwater resources of the Dockum aquifer in Texas: Texas Water Development Board Report 359, 73 p.

Brand, J.P., and DeFord, R.K., 1958, Comanchean stratigraphy of Kent quadrangle, Trans-Pecos, Texas: Austin, Tex., University of Texas Bulletin 1753, p. 67-172.

Brookins, D.G., 1988, Seawater $87 \mathrm{Sr} / 86 \mathrm{Sr}$ for the Late Permian Delaware Basin evaporites (New Mexico, U.S.A): Chemical Geology, v. 69, p. 209-214.

Boghici, Radu, 1997, Hydrogeological investigations at Diamond Y Springs and surrounding area, Pecos County, Texas: The University of Texas, M.A. thesis, 132 p.

Burke, W.H., Dennison, R.E., Hetherington, E.A., Koepnick, R.B., Nelson, H.F., Otto, J.B., 1982, Variation of seawater 87Sr/86Sr throughout Phanerozoic time: Geology, v. 10, p. 516-519.

Cameron, K.L., Parker, D.F., and Sampson, D.E., 1996, Testing crustal melting models for the origin of flood rhyolites - A Nd-Pb-Sr isotopic study of the Tertiary Davis Mountains volcanic field, west Texas: Journal of Geophysical Research, v. 101, p. 20407-20422.

Casciotti, K.L., Sigman, D.M., Hastings, M.G., Böhlke, J.K., and Hilkert, A., 2002, Measurement of the oxygen isotopic composition of nitrate in seawater and freshwater using the denitrifier method: Analytical Chemistry, v. 74, p. 49054912.

Clark, I.D., and Fritz, Peter, 1997, Environmental isotopes in hydrogeology: Boca Raton, Fla., Lewis Publishers, 328 p.

Cooper, H.H., Jr., and Jacob, C.E., 1946, A generalized graphical method for evaluating formation constants and summarizing well-field history: American Geophysical Union Transactions, v. 27 , no. 4, p. 526-534.

Craig, Harmon, 1961, Isotopic variations in meteoric waters: Science, v. 133, p. 1702-1703.

Daniel B. Stephens and Associates, 2010, City of Fort Stockton groundwater availability analysis-Evaluation of pumping on city wells: Prepared for the City of Fort Stockton, $79 \mathrm{p}$.

Denison, R.E., Kirkland, D.W., Evans, Robert, 1998, Using strontium isotopes to determine the age and origin of gypsum and anhydrite beds: Journal of Geology, v. 106, p. $1-17$.

Driscoll, F.G., 1986, Groundwater and wells: Johnson Filtration Systems, 1089 p.

Dubrovsky, N.M., Burow, K.R., Clark, G.M., Gronberg, J.M., Hamilton P.A., Hitt, K.J., Mueller, D.K., Munn, M.D., Nolan, B.T., Puckett, L.J., Rupert, M.G., Short, T.M., Spahr, N.E., Sprague, L.A., and Wilber, W.G., 2010, The quality of our Nation's waters-Nutrients in the Nation's streams and groundwater, 1992-2004: U.S. Geological Survey Circular $1350,174 \mathrm{p}$
Faure, Gunter, 1986, Principles of isotope geology: New York, Wiley, $589 \mathrm{p}$.

Fenneman, N.M., and Johnson, D.W., 1946, Physical divisions of the United States: U.S. Geological Survey, 1 sheet, scale $1: 7,000,000$.

Ferris, J.G., Knowles, D.B., Brown, R.H., and Stallman, R.W., 1962, Theory of aquifer tests: U.S. Geological Survey Water-Supply Paper 1536-E, 105 p.

Fetter, C.W., 1988, Applied hydrogeology: New York, Macmillan, $592 \mathrm{p}$.

Freese and Nichols, LBG-Guyton, 2010, 2011 Region F water plan: Prepared for Region F Water Planning Group, 500 p.

Fry, J.A., Xian, George, Jin, Suming, Dewitz, J.A., Homer, C.G., Yang, Limin, Barnes, C.A., Herold, N.D., and Wickham, J.D., 2011, Completion of the 2006 National Land Cover Database for the conterminous United States: Photogrammetric Engineering and Remote Sensing, v. 77, no. 9 , p. $858-864$.

George, P.G., Mace, R.E., and Petrossian, Rima, 2011, Aquifers of Texas: Texas Water Development Board Report $380,172 \mathrm{p}$.

Geosoft, Inc., 2012, Technical workshop-Topics in gridding: accessed January 18, 2012, at http://geosoft. com/media/uploads/resources/technical-papers/ topicsingriddingworkshop.pdf.

Hem, J.D., 1992, Study and interpretation of chemical characteristics of natural water (3d ed.): U.S. Geological Survey Water-Supply Paper 2254, 263 p.

Herald, F.A., ed., 1957, Occurrence of oil and gas in west Texas: University of Texas Bureau of Economic Geology, 442 p., 3 pls.

Hiss, W.L., 1976, Stratigraphy and ground-water hydrology of the Capitan aquifer, southeastern New Mexico and western Texas: University of Colorado, Ph.D. dissertation, 501 p.

International Atomic Energy Agency, 2011, Global networks of isotopes in precipitation: accessed March 31, 2011, at http://www-naweb.iaea.org/napc/ih/IHS_resources_gnip. html.

INTERRA Incorporated, 2011, Draft conceptual model report for the Rustler aquifer: Prepared for the Texas Water Development Board, $252 \mathrm{p}$.

Keller, G.V., and Frischknecht, F.C., 1966, Electrical methods in geophysical prospecting (1st ed.): Oxford, Pergamon Press, $519 \mathrm{p}$.

Keys, W.S., 1990, Borehole geophysics applied to groundwater investigations: Techniques of Water-Resources Investigations of the U.S. Geological Survey, chap. E2, $150 \mathrm{p}$. 
Keys, W.S., 1997, A practical guide to borehole geophysics in environmental investigations: CRC-Lewis Publishers, $176 \mathrm{p}$.

LBG-Guyton, 2003, Brackish groundwater manual for Texas regional water planning groups: Prepared for the Texas Water Development Board, 188 p.

LaFave, J.I., and Sharp, J.M., 1987, Origins of groundwater discharging at the springs of Balmorhea: West Texas Geological Society Bulletin, v. 26, p. 5-14.

Langman, J.B., and Ellis, A.S., 2010, A multi-isotope ( $\delta$ D, $\delta 18 \mathrm{O}, 87 \mathrm{Sr} / 86 \mathrm{Sr}$, and $\delta 11 \mathrm{~B}$ ) approach for identifying saltwater intrusion and resolving groundwater evolution along the Western Caprock Escarpment of the Southern High Plains, New Mexico: Applied Geochemistry, v. 25, p. 159-174.

Lucas, L.L., and Unterweger, M.P., 2000, Comprehensive review and critical evaluation of the half-life of tritium: Journal of Research of the National Institute of Standards and Technology, v. 105 , no. 4, p. 541-549.

Lucius, J.E., Langer, W.H., and Ellefsen, K.J., 2007, An introduction to using surface geophysics to characterize sand and gravel deposits: U.S. Geological Survey Circular $1310,33 \mathrm{p}$.

Meyer, J.E., Wise, M.R., and Kalaswad, Sanjeev, 2011, Pecos Valley aquifer, west Texas-Structure and brackish groundwater: Texas Water Development Board Brackish Resources Aquifer Characterization System (BRACS), 92 p.

Meyers, B.N., 1969, Compilation of results of aquifer tests in Texas: Texas Water Development Board Report 98 (part 1 and 2), $534 \mathrm{p}$.

Musgrove, MaryLynn, and Banner, J.L., 1993, Regional groundwater mixing and the origin of saline fluidsMidcontinent, United States: Science, v. 259, p. 1877-1882.

Musgrove, MaryLynn, Fahlquist, Lynne, Houston, N.A., Lindgren, R.J., and Ging, P.B., 2009, Geochemical evolution processes and water-quality observations based on results of the National Water-Quality Assessment Program in the San Antonio segment of the Edwards aquifer, 19962006: U.S. Geological Survey Scientific Investigations Report 2010-5129, 93 p.

National Atmospheric Deposition Program (IR-7)/National Trends Network, 1997, Annual report: Fort Collins, Colo., NADP/NTN Coordination Office, Natural Resource Ecology Laboratory, Colorado State University, p. 103.

National Weather Service, 2011, Fort Stockton cooperative precipitation, normals 1970-2000, precipitation 1940-2012: accessed June 13, 2012, at http://www.srh.weather.gov/ $\mathrm{maf} / \mathrm{n}=\mathrm{cli}$ _maf_coop_annprecip_fort_stockton.
Neuendorf, K.K.E., Mehl, J.P., Jr., and Jackson, J.A., eds., 2005, Glossary of geology (5th ed.): Alexandria, Va., American Geological Institute, 779 p.

Oden, J.H., Brown, D.W., and Oden, T.D., 2011, Groundwater quality of the gulf coast aquifer system, Houston, Texas, 2010: U.S. Geological Survey Data Series 598, 64 p.

Pearson, D.K., Bumgarner, J.R., Houston, N.A., Stanton, G.P., Teeple, A.P. and Thomas, J.V., 2012, Data collection and compilation for a geodatabase of groundwater, surfacewater, water-quality, geophysical, and geologic data, Pecos County region, Texas, 1930-2011: U.S. Geological Survey Data Series 678, $67 \mathrm{p}$.

Phillips, F.M., and Castro, M.C., 2003, Groundwater dating and residence-time measurements, in Drever, J.I., ed., 2005, Surface and ground water, weathering, and soils-Treatise on geochemistry: Boston, Elsevier, p. 451-497.

Piper, A.M., 1953, A graphic procedure in the geochemical interpretation of water analysis: U.S. Geological Survey Ground Water Note No. 12, 14 p.

Railroad Commission of Texas, 2010, Geophysical log database: accessed September 30, 2011, at http://rrcsearch. neubus.com/esd-rrc/\#results.

Rees, R.A., and Buckner, Wayne, 1980, Occurrence and quality of ground water in the Edwards-Trinity (Plateau) aquifer, in the Trans-Pecos region: Texas Water Development Board Report 255, 40 p.

Ritzema, H.P., 1994, Determining the saturated hydraulic conductivity, chap. 12 of Ritzema, H.P., ed., Drainage principles and applications ( $2 \mathrm{~d}$ ed.): Wageningen, The Netherlands, International Institute for Land Reclamation and Improvement, $40 \mathrm{p}$.

Rose, P.R., 1972, Edwards Group, surface and subsurface central Texas: Austin, Tex., University of Texas, Bureau of Economic Geology Report of Investigations 74, 198 p.

Schlosser, Peter, Stute, Martin, Dörr, Helmut, Sonntag, Christian, and Münnich, K.O., 1988, Tritium $/{ }^{3} \mathrm{He}$ dating of shallow groundwater: Earth and Planetary Science Letters, v. 89 , p. $353-362$.

Schlosser, Peter, Stute, Martin, Sonntag, Christian, and Münnich, K.O., 1989, Tritiogenic ${ }^{3} \mathrm{He}$ in shallow groundwater: Earth and Planetary Science Letters, v. 94, p. $245-256$.

Sharp, J.M., Uliana, M.M., and Boghici, Radu, 1999, Fracture controls on regional groundwater flow in a semiarid environment and implications for long-term maintenance of spring flows, in Water 99 Joint Congress-Institution of Engineers, 25th Hydrology \& Water Resources Symposium, Brisbane, Australia, July 6-8, 1999: Institution of Engineers, v. 2, p. 1212-1217. 
Sharp, J.R., 2001, Regional groundwater flow systems in Trans-Pecos, Texas, in Mace, R.E., Mullican, W.F., III, Angle, E.S., eds., Aquifers of west Texas: Texas Water Development Board Report 356, p. 41-55.

Small, T.A., and Ozuna, G.B., 1993, Ground-water conditions in Pecos County, Texas, 1987: U.S. Geological Survey Water-Resources Investigations Report 92-4190, 68 p.

Smith, C.I., and Brown, J.B., 1983, Introduction to road log Cretaceous stratigraphy: West Texas Geological Society Field Trip Guidebook, no. 83-77, p. 1-4.

Smith, C.I., and Brown, J.B., and Lozo, F.E., 2000, Regional stratigraphic cross sections, Commanche Cretaceous (Fredericksburg-Washita Division), Edwards and Stockton Plateaus, West Texas - Interpretation of sedimentary Facies, depositional cycles, and tectonics: Austin, Tex., The University of Texas, Bureau of Economic Geology, 39 p.

Solomon, D.K., and Cook, P.G., 1999, ${ }^{3} \mathrm{H}$ and ${ }^{3} \mathrm{He}$, in Cook, Peter, and Herczeg, Andres, eds., Environmental tracers in subsurface hydrology: New York, Kluwer Academic Publishers, p. 397-424.

Texas Parks and Wildlife Department, 2012, Comanche Springs Pupfish (Cyprinodon elegans): accessed May 10, 2012, at http://www.tpwd.state.tx.us/huntwild/wild/species/ comanchespringspupfish/.

Texas Water Development Board, 1972, A survey of the subsurface saline water of Texas: Texas Water Development Board Report 157, 113 p.

Texas Water Development Board, 2005, Diminished spring flows in the San Solomon Springs system, Trans-Pecos, Texas: Report to the Texas Parks and Wildlife Department, $121 \mathrm{p}$.

Texas Water Development Board, 2011, Groundwater database reports: accessed December 19, 2011, at http://www.twdb. state.tx.us/publications/reports/GroundWaterReports/ GWDatabaseReports/GWdatabaserpt.asp.

Thatcher, L.L., Janzer, V.J., and Edwards, K.W., 1977, Methods for determination of radioactive substances in water and fluvial sediments: U.S. Geological Survey Techniques of Water-Resources Investigations, book 5, chap. A5, 95 p.

Theis, C.V., 1935, The relation between the lowering of the piezometric surface and the rate and duration of discharge of a well using ground-water storage: American Geophysical Union Transactions, 16th annual meeting, p. 519-524.
Thiem, Gunther, 1906, Hydrologische methoden [Hydrologic methods]: Leipzig, Germany, J.M. Gebhardt, 56 p.

Thornhill Group, Inc., 2008, Edwards-Trinity aquifer studyLeon-Belding area: Prepared for Clayton Williams Farms, Inc., $80 \mathrm{p}$.

Thornhill Group, Inc., 2009, Results of pumping testsWilliams Farms Pecos County, Texas: Prepared for Fort Stockton Holdings, L.P., 257 p.

Uliana, M.M., Banner, J.L., and Sharp, J.M., 2007, Regional groundwater flow paths in Trans-Pecos, Texas inferred from oxygen, hydrogen, and strontium isotopes: Journal of Hydrology, v. 334, p. 334-346.

Uliana, M.M., and Sharp, J.M., 2001, Tracing regional flow paths to major springs in Trans-Pecos, Texas using geochemical data and geochemical models: Chemical Geology, v. 179, p. 53-72.

University Lands, 2011, Well library: accessed July 1, 2011, at http://www.utlands.utsystem.edu/techdata.aspx.

U.S. Geological Survey, 2011, National Water Information System (NWISWeb) data: accessed December 19, 2011, at http://waterdata.usgs.gov/tx/nwis/nwis.

Veni, George, 1991, Delineation and preliminary hydrogeologic investigations of the Diamond Y Spring, Pecos County, Texas: Report to the Nature Conservancy of Texas, $110 \mathrm{p}$.

Wenzel, L. K., 1942, Methods for determining permeability of water-bearing materials, with special reference to discharging-well methods, with a section on Direct laboratory methods and bibliography on permeability and laminar flow, by V.C. Fishel: U.S. Geological Survey WaterSupply Paper 887, 192 p.

Wermund, E.G., 1996, Physiographic map of Texas: Bureau of Economic Geology Map SM0005.

Zaugg, S.D., Sandstrom, M.W., Smith, S.G., and Fehlberg, K.M., 1995, Methods of analysis by the U.S. Geological Survey National Water Quality Laboratory-Determination of pesticides in water by $\mathrm{C}-18$ solid-phase extraction and capillary-column gas chromatography/mass spectrometry with selected-ion monitoring: U.S. Geological Survey Open-File Report 95-181, 60 p.

Zohdy, A.A.R., Eaton, G.P., and Mabey, D.R., 1974, Application of surface geophysics to ground-water investigations: U.S. Geological Survey Techniques of Water-Resources Investigations, book 2, chap. D1. 
Table 1. Hydrostratigraphic section in the Pecos County region study area, Texas (modified from Brand and DeFord, 1958; Rose, 1972; Rees and Buckner, 1980; Smith and Brown, 1983; and Ashworth and Hopkins, 1995).

[Water-yielding properties: yields (gallons per minute) - small less than 50, moderate 50 to 500, large is more than 500; classification of water dissolved-solids concentration (milligrams per liter) - fresh less than 1,000 , slightly saline 1,000 to 3,000 , moderately saline 3,000 to 10,000 .]

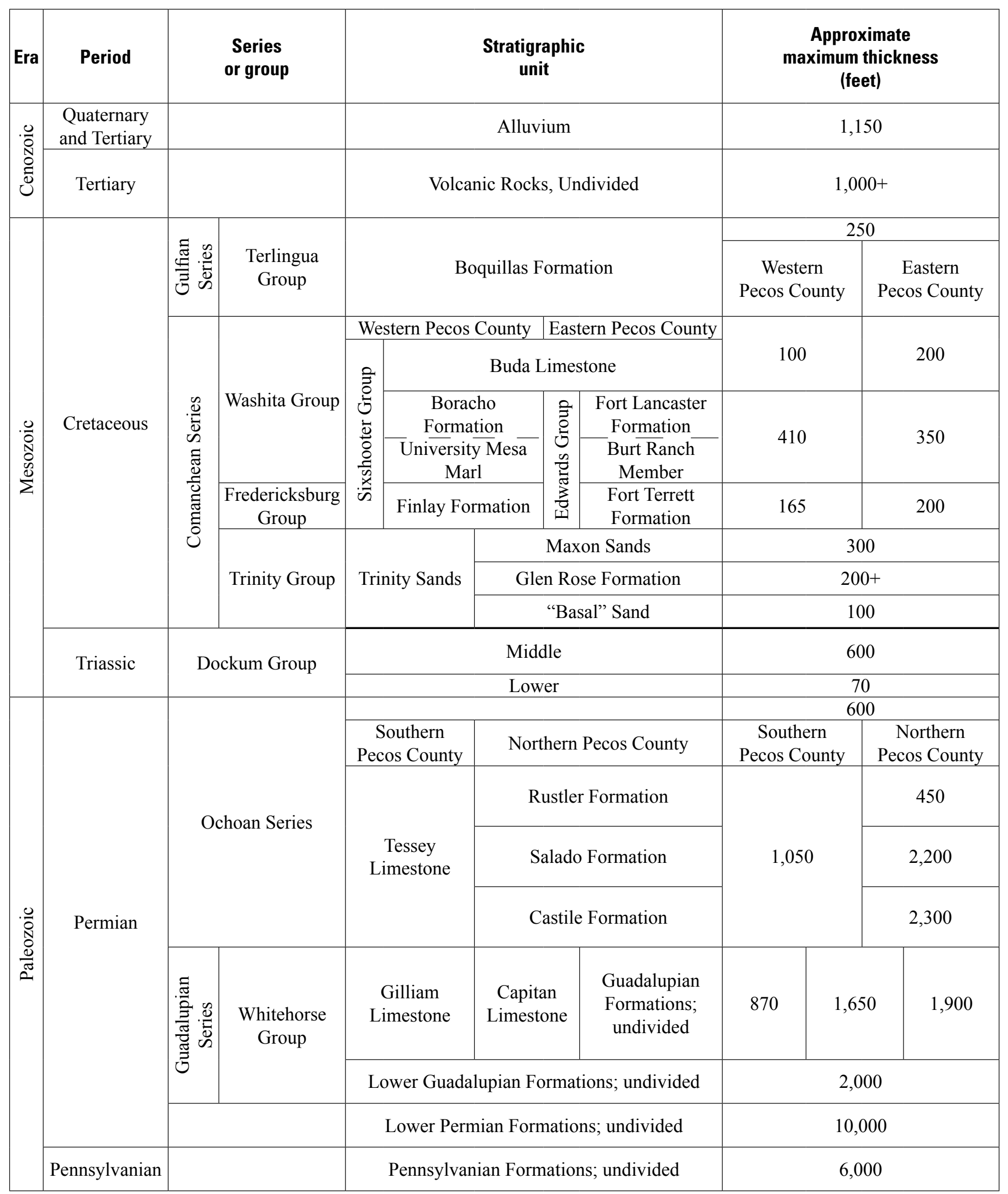


Table 1. Hydrostratigraphic section in the Pecos County region study area, Texas (modified from Brand and DeFord, 1958; Rose, 1972; Rees and Buckner, 1980; Smith and Brown, 1983; and Ashworth and Hopkins, 1995)._-Continued

[Water-yielding properties: yields (gallons per minute) - small less than 50, moderate 50 to 500, large is more than 500; classification of water dissolved-solids concentration (milligrams per liter) - fresh less than 1,000, slightly saline 1,000 to 3,000, moderately saline 3,000 to 10,000 .]

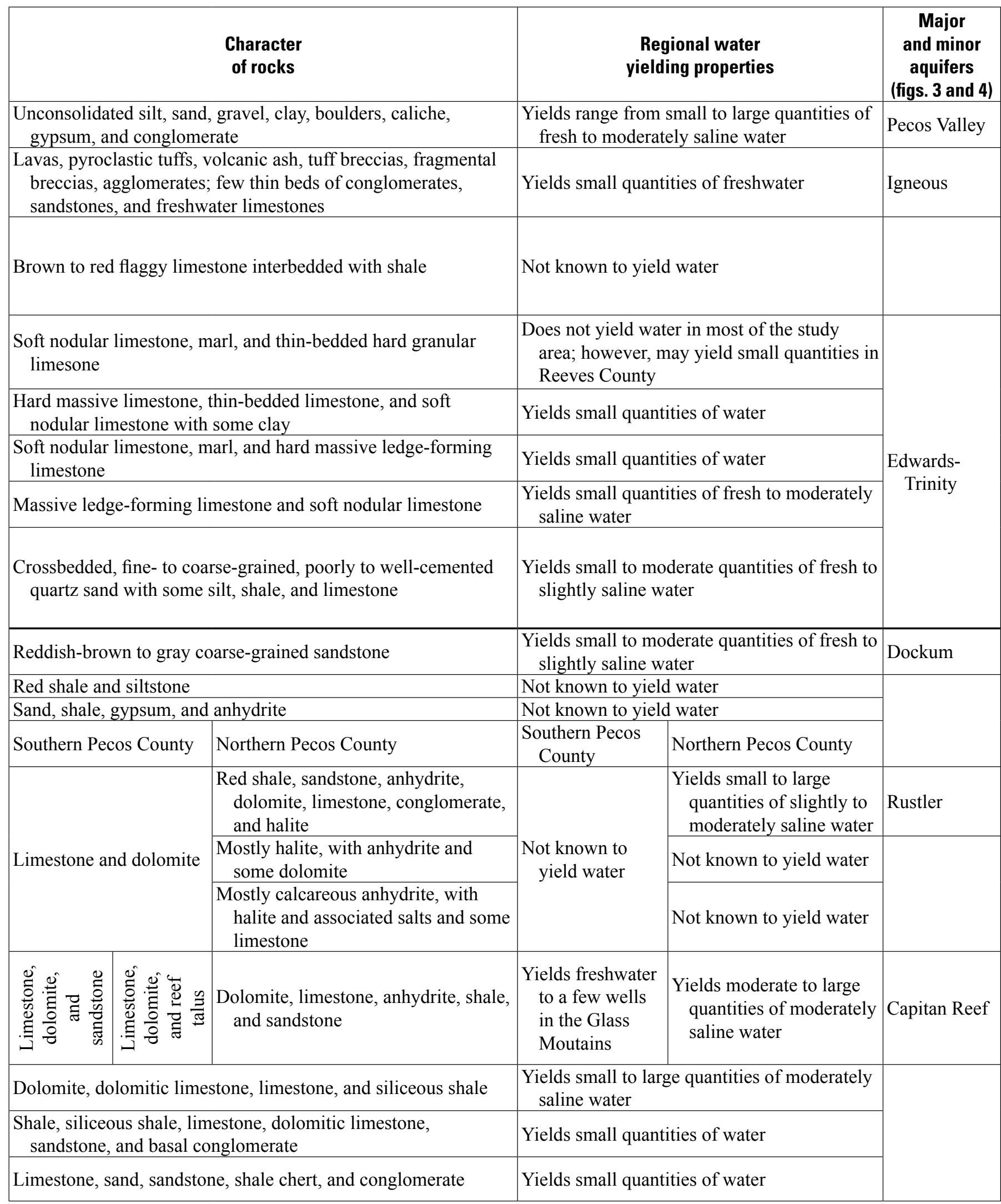


Table 2. Sites contributing well reports, borehole geophysical logs, and surface geophysical soundings used to determine the lithologies, hydrostratigraphic units, and tops and bases of the hydrostratigraphic units in the Pecos County region study area, Texas.

$[--$, not used $]$

\begin{tabular}{|c|c|c|c|c|c|c|}
\hline $\begin{array}{c}\text { Site } \\
\text { identifier } \\
\text { (fig. 7) }\end{array}$ & $\begin{array}{c}\text { Latitude } \\
\text { (decimal degrees) }\end{array}$ & $\begin{array}{c}\text { Longitude } \\
\text { (decimal degrees) }\end{array}$ & $\begin{array}{l}\text { Land surface } \\
\text { altitude } \\
\text { (feet) }\end{array}$ & $\begin{array}{l}\text { Altitude of the top } \\
\text { of the Edwards- } \\
\text { Trinity aquifer } \\
\text { (feet) }\end{array}$ & $\begin{array}{c}\text { Altitude of } \\
\text { the top of the } \\
\text { Trinity Group } \\
\text { (feet) }\end{array}$ & $\begin{array}{c}\text { Altitude of the base } \\
\text { of the Edwards- } \\
\text { Trinity aquifer } \\
\text { (feet) }\end{array}$ \\
\hline 302122102504501 & 30.35600 & 102.35600 & 3,113 & 3,091 & 3,046 & 2,957 \\
\hline 302630102503801 & 30.44176 & 102.84396 & 4,354 & 4,234 & 4,234 & 3,982 \\
\hline 303503102303601 & 30.58421 & 102.51007 & 3,413 & 3,228 & 3,228 & 2,903 \\
\hline 303824102285001 & 30.64000 & 102.48052 & 3,264 & 3,129 & 3,129 & 2,974 \\
\hline 303852102432901 & 30.64790 & 102.72471 & 3,548 & 3,398 & 3,328 & 2,998 \\
\hline 303948103205801 & 30.66344 & 103.34970 & 3,545 & 3,483 & 3,450 & 3,350 \\
\hline 304134102312601 & 30.69279 & 102.52399 & 3,170 & 3,153 & 3,035 & 2,902 \\
\hline 304153103090501 & 30.69796 & 103.15140 & 3,384 & 3,285 & 3,167 & 2,992 \\
\hline 304210102443201 & 30.70269 & 102.74228 & 3,480 & 3,380 & 3,220 & 3,071 \\
\hline 304551102361201 & 30.76448 & 102.60387 & 2,929 & 2,929 & 2,849 & 2,766 \\
\hline 304622102312401 & 30.77304 & 102.52379 & 3,333 & 3,257 & 3,119 & 3,033 \\
\hline 304711103003301 & 30.78642 & 103.00932 & 3,239 & 3,196 & 3,078 & 2,939 \\
\hline 304715103263501 & 30.78740 & 103.44343 & 3,447 & -- & 3,152 & 2,987 \\
\hline 304728102304401 & 30.79098 & 102.51216 & 3,067 & 3,067 & 3,017 & 2,817 \\
\hline 305042102595601 & 30.84509 & 102.99899 & 3,088 & 3,076 & 2,958 & -- \\
\hline 305055103110801 & 30.84864 & 103.18567 & 3,121 & 3,093 & 2,871 & 2,761 \\
\hline 305548103161401 & 30.93771 & 103.26958 & 3,037 & 3,017 & 2,797 & 2,597 \\
\hline 305604102581301 & 30.93455 & 102.97030 & 2,907 & -- & -- & 2,605 \\
\hline 305627103071901 & 30.94075 & 103.12200 & 2,991 & -- & 2,695 & 2,263 \\
\hline 305706102095501 & 30.95175 & 102.16536 & 2,981 & 2,981 & 2,741 & 2,471 \\
\hline 305740103110901 & 30.96120 & 103.18608 & 2,979 & 2,949 & 2,879 & 2,779 \\
\hline 305835102134701 & 31.01156 & 102.25855 & 2,302 & 2,162 & 2,044 & 1,894 \\
\hline 310041102152901 & 30.97650 & 102.22977 & 2,370 & 2,340 & 2,296 & 2,225 \\
\hline BRACS-0101 & 31.04111 & 103.38472 & 2,903 & 2,803 & -- & 2,753 \\
\hline BRACS-0109 & 30.97583 & 103.73055 & 3,181 & 2,902 & 2,595 & 2,402 \\
\hline BRACS-0111 & 31.22222 & 102.93222 & 2,530 & 2,517 & -- & 2,212 \\
\hline BRACS-0113 & 31.00083 & 103.09472 & 2,943 & 2,878 & -- & -- \\
\hline BRACS-0135 & 31.20805 & 102.93778 & 2,549 & 2,534 & -- & -- \\
\hline BRACS-0138 & 30.95333 & 102.83305 & 2,832 & 2,652 & -- & 2,363 \\
\hline BRACS-0157 & 31.24750 & 102.91972 & 2,500 & 2,492 & -- & 2,080 \\
\hline BRACS-0160 & 31.23889 & 102.91944 & 2,509 & 2,501 & -- & 2,082 \\
\hline BRACS-0192 & 31.06472 & 103.40722 & 2,884 & 2,804 & -- & 2,624 \\
\hline BRACS-0198 & 31.03972 & 102.81583 & 2,685 & 2,664 & -- & 2,355 \\
\hline BRACS-0209 & 30.96167 & 103.33000 & 3,040 & 2,965 & -- & 2,682 \\
\hline BRACS-0210 & 30.94611 & 103.41000 & 3,161 & 3,156 & -- & 2,780 \\
\hline BRACS-0299 & 31.04944 & 102.35222 & 2,333 & 2,298 & 2,264 & 2,218 \\
\hline BRACS-0308 & 30.93000 & 103.46000 & 3,145 & 3,095 & -- & 2,724 \\
\hline BRACS-0328 & 30.91333 & 103.17722 & 3,039 & 3,004 & -- & 2,647 \\
\hline BRACS-0341 & 31.14444 & 102.56722 & 2,388 & 2,364 & -- & 2,199 \\
\hline BRACS-0519 & 31.20830 & 103.07636 & 2,653 & 2,023 & 2,003 & 1,593 \\
\hline BRACS- 0520 & 31.21101 & 103.05238 & 2,634 & 2,086 & 2,044 & 1,619 \\
\hline BRACS-0521 & 31.17668 & 103.02671 & 2,660 & 2,150 & 2,150 & 1,749 \\
\hline BRACS-0522 & 31.04934 & 103.02272 & 2,778 & 2,616 & 2,498 & 2,313 \\
\hline BRACS-0523 & 31.00094 & 103.09373 & 2,944 & 2,876 & 2,614 & 2,494 \\
\hline BRACS-0524 & 30.96626 & 103.20461 & 2,963 & 2,813 & 2,813 & 2,663 \\
\hline BRACS-0525 & 31.19085 & 102.83513 & 2,472 & 2,437 & -- & 2,107 \\
\hline
\end{tabular}


Table 2. Sites contributing well reports, borehole geophysical logs, and surface geophysical soundings used to determine the lithologies, hydrostratigraphic units, and tops and bases of the hydrostratigraphic units in the Pecos County region study area, Texas.-Continued

$[--$, not used $]$

\begin{tabular}{|c|c|c|c|c|c|c|}
\hline $\begin{array}{c}\text { Site } \\
\text { identifier } \\
\text { (fig. 7) }\end{array}$ & $\begin{array}{c}\text { Latitude } \\
\text { (decimal degrees) }\end{array}$ & $\begin{array}{c}\text { Longitude } \\
\text { (decimal degrees) }\end{array}$ & $\begin{array}{l}\text { Land surface } \\
\text { altitude } \\
\text { (feet) }\end{array}$ & $\begin{array}{l}\text { Altitude of the top } \\
\text { of the Edwards- } \\
\text { Trinity aquifer } \\
\text { (feet) }\end{array}$ & $\begin{array}{c}\text { Altitude of } \\
\text { the top of the } \\
\text { Trinity Group } \\
\text { (feet) }\end{array}$ & $\begin{array}{c}\text { Altitude of the base } \\
\text { of the Edwards- } \\
\text { Trinity aquifer } \\
\text { (feet) }\end{array}$ \\
\hline BRACS-0526 & 30.99283 & 102.21311 & 2,304 & 2,054 & 2,039 & 1,844 \\
\hline BRACS-0542 & 31.10201 & 102.55492 & 2,395 & 2,355 & 2,293 & 2,175 \\
\hline BRACS-0544 & 30.98961 & 102.26984 & 2,338 & 2,176 & 2,058 & 1,938 \\
\hline BRACS-0627 & 31.02472 & 102.84555 & 2,870 & 2,870 & -- & 2,489 \\
\hline BRACS-0633 & 31.21417 & 103.02917 & 2,617 & 2,252 & -- & 1,742 \\
\hline BRACS-0730 & 30.93423 & 102.93300 & 2,925 & 2,845 & 2,845 & 2,695 \\
\hline BRACS-0731 & 30.94153 & 102.94986 & 2,903 & 2,813 & 2,813 & 2,663 \\
\hline BRACS-0732 & 31.22609 & 102.83262 & 2,442 & 2,402 & 2,402 & 2,183 \\
\hline BRACS-0733 & 30.94907 & 103.03827 & 3,035 & 3,035 & 2,965 & 2,615 \\
\hline BRACS-0734 & 30.96357 & 103.00668 & 2,958 & 2,848 & 2,748 & 2,568 \\
\hline BRACS-0735 & 31.22850 & 102.85153 & 2,454 & 2,354 & 2,354 & 2,154 \\
\hline BRACS-0736 & 31.15706 & 102.94037 & 2,582 & 2,547 & 2,252 & 2,097 \\
\hline BRACS-0737 & 31.04779 & 103.01047 & 2,777 & 2,677 & 2,617 & 2,437 \\
\hline BRACS-0738 & 31.24765 & 102.86736 & 2,457 & 2,422 & 2,422 & 2,197 \\
\hline BRACS-0739 & 30.98453 & 103.05897 & 2,920 & 2,810 & 2,710 & 2,535 \\
\hline BRACS-0741 & 30.80259 & 102.99008 & 3,193 & 3,143 & 3,023 & 2,833 \\
\hline BRACS-0744 & 31.19169 & 102.88496 & 2,519 & 2,469 & 2,369 & 2,147 \\
\hline BRACS-0746 & 31.01443 & 102.84010 & 2,851 & 2,826 & 2,661 & 2,401 \\
\hline BRACS-0747 & 31.19244 & 102.93365 & 2,550 & 2,500 & -- & -- \\
\hline BRACS-0749 & 30.82914 & 102.95679 & 3,104 & 3,044 & 2,989 & -- \\
\hline BRACS-0753 & 31.20135 & 102.94071 & 2,559 & 2,509 & 2,374 & 2,246 \\
\hline BRACS-0755 & 31.13003 & 102.89910 & 2,610 & 2,540 & 2,480 & 2,280 \\
\hline BRACS-0757 & 30.80957 & 102.94955 & 3,187 & 3,047 & -- & -- \\
\hline BRACS-0762 & 31.25080 & 102.84100 & 2,430 & 2,335 & 2,335 & 2,140 \\
\hline BRACS-0764 & 30.91562 & 103.00171 & 2,990 & -- & -- & 2,545 \\
\hline BRACS-0766 & 31.00553 & 102.94862 & 2,799 & 2,564 & -- & -- \\
\hline BRACS-0768 & 30.80934 & 102.93241 & 3,206 & 3,106 & 3,076 & 2,936 \\
\hline BRACS-0769 & 30.84665 & 102.94038 & 3,068 & 3,048 & 3,048 & 2,843 \\
\hline BRACS-0770 & 31.12670 & 102.94008 & 2,624 & 2,589 & 2,414 & 2,154 \\
\hline BRACS-0771 & 31.08683 & 102.91504 & 2,711 & 2,711 & 2,601 & 2,451 \\
\hline BRACS-0772 & 31.09040 & 102.92793 & 2,681 & 2,681 & 2,578 & 2,428 \\
\hline BRACS-0773 & 30.74136 & 102.93528 & 3,551 & 3,551 & 3,451 & 3,266 \\
\hline BRACS-0777 & 31.03613 & 102.93529 & 2,818 & 2,818 & 2,668 & 2,538 \\
\hline BRACS-0780 & 30.85778 & 102.93244 & 3,057 & 3,007 & -- & -- \\
\hline BRACS-0782 & 30.97206 & 102.89709 & 2,864 & 2,864 & 2,784 & 2,642 \\
\hline BRACS-0783 & 30.75097 & 103.14153 & 3,534 & 3,534 & 3,534 & 3,206 \\
\hline BRACS-0934 & 30.97444 & 103.27250 & 2,974 & 2,829 & -- & 2,548 \\
\hline BRACS-0935 & 30.93805 & 103.25944 & 3,030 & 3,002 & -- & 2,620 \\
\hline BRACS-0937 & 30.97417 & 103.64028 & 3,001 & 2,418 & -- & -- \\
\hline BRACS-0943 & 31.01306 & 103.52000 & 2,950 & 2,844 & 2,844 & 2,570 \\
\hline BRACS-0944 & 31.05306 & 103.46139 & 2,921 & 2,776 & -- & 2,597 \\
\hline BRACS-0963 & 31.07917 & 103.62333 & 2,894 & 2,304 & -- & 1,955 \\
\hline BRACS-0974 & 30.97194 & 102.17528 & 2,383 & 2,383 & -- & 2,021 \\
\hline BRACS-0990 & 30.99667 & 102.37555 & 2,487 & 2,487 & -- & -- \\
\hline BRACS-1028 & 31.06139 & 103.62000 & 2,911 & 2,326 & -- & 1,986 \\
\hline BRACS-1192 & 31.03447 & 103.47014 & 2,954 & 2,764 & 2,764 & 2,714 \\
\hline
\end{tabular}


Table 2. Sites contributing well reports, borehole geophysical logs, and surface geophysical soundings used to determine the lithologies, hydrostratigraphic units, and tops and bases of the hydrostratigraphic units in the Pecos County region study area, Texas.-Continued

$[--$, not used $]$

\begin{tabular}{|c|c|c|c|c|c|c|}
\hline $\begin{array}{c}\text { Site } \\
\text { identifier } \\
\text { (fig. 7) }\end{array}$ & $\begin{array}{c}\text { Latitude } \\
\text { (decimal degrees) }\end{array}$ & $\begin{array}{c}\text { Longitude } \\
\text { (decimal degrees) }\end{array}$ & $\begin{array}{l}\text { Land surface } \\
\text { altitude } \\
\text { (feet) }\end{array}$ & $\begin{array}{l}\text { Altitude of the top } \\
\text { of the Edwards- } \\
\text { Trinity aquifer } \\
\text { (feet) }\end{array}$ & $\begin{array}{c}\text { Altitude of } \\
\text { the top of the } \\
\text { Trinity Group } \\
\text { (feet) }\end{array}$ & $\begin{array}{c}\text { Altitude of the base } \\
\text { of the Edwards- } \\
\text { Trinity aquifer } \\
\text { (feet) }\end{array}$ \\
\hline BRACS-1201 & 31.15030 & 103.03856 & 2,706 & 2,311 & 2,311 & 1,880 \\
\hline BRACS-1203 & 31.18958 & 102.87461 & 2,512 & 2,477 & 2,457 & 2,155 \\
\hline BRACS-1212 & 31.13737 & 102.51653 & 2,391 & 2,315 & -- & 2,161 \\
\hline BRACS-1213 & 31.07577 & 102.45276 & 2,333 & 2,303 & 2,283 & 2,103 \\
\hline BRACS-1214 & 31.07524 & 102.36937 & 2,289 & 2,239 & 2,239 & 2,069 \\
\hline BRACS-1345 & 31.01694 & 103.69972 & 3,084 & 2,564 & 2,334 & 2,184 \\
\hline BRACS-1346 & 31.04028 & 103.58972 & 2,882 & 2,697 & 2,662 & 2,402 \\
\hline BRACS-1347 & 31.01917 & 103.51778 & 2,945 & -- & -- & 2,625 \\
\hline BRACS-1354 & 30.96944 & 103.55333 & 2,967 & -- & 2,484 & 2,334 \\
\hline BRACS-1355 & 30.97722 & 103.52889 & 2,980 & 2,980 & -- & -- \\
\hline BRACS-1478 & 30.95732 & 103.36377 & 3,066 & 3,066 & -- & 2,721 \\
\hline BRACS-1479 & 30.99617 & 103.28807 & 2,955 & 2,902 & -- & 2,655 \\
\hline BRACS-1481 & 31.14586 & 103.00910 & 2,682 & 2,332 & -- & 1,946 \\
\hline BRACS-1482 & 31.09035 & 103.03724 & 2,780 & 2,450 & -- & -- \\
\hline BRACS-1521 & 31.02076 & 103.52570 & 2,936 & -- & -- & 2,606 \\
\hline BRACS-1522 & 30.93780 & 103.31012 & 3,075 & 3,025 & -- & 2,699 \\
\hline BRACS-1523 & 30.93539 & 103.26028 & 3,036 & 3,022 & -- & 2,635 \\
\hline BRACS-1525 & 30.86167 & 103.42722 & 3,306 & 3,306 & -- & 2,962 \\
\hline BRACS-1527 & 30.96861 & 103.39271 & 3,044 & 3,016 & -- & 2,734 \\
\hline BRACS-1530 & 31.00844 & 103.37838 & 2,945 & 2,945 & -- & 2,796 \\
\hline BRACS-1532 & 30.97841 & 103.53645 & 2,972 & 2,954 & -- & -- \\
\hline BRACS-1533 & 30.94464 & 103.57559 & 3,010 & 2,775 & -- & 2,233 \\
\hline BRACS-1538 & 30.90699 & 103.57838 & 3,138 & 2,963 & -- & 2,456 \\
\hline BRACS-1540 & 31.02707 & 103.55891 & 2,896 & 2,896 & -- & 2,583 \\
\hline BRACS-1541 & 31.05026 & 103.60564 & 2,895 & 2,415 & -- & 2,092 \\
\hline BRACS-1568 & 31.00827 & 103.20741 & 2,903 & 2,573 & -- & 2,320 \\
\hline BRACS-1586 & 30.93806 & 103.18667 & 3,016 & 3,016 & -- & 2,739 \\
\hline BRACS-1625 & 31.05021 & 102.36771 & 2,366 & 2,256 & 2,251 & 2,116 \\
\hline BRACS-1626 & 30.95847 & 102.90540 & 2,870 & 2,810 & -- & 2,605 \\
\hline BRACS-1627 & 31.00020 & 103.12570 & 2,917 & 2,867 & 2,715 & 2,603 \\
\hline BRACS-1628 & 30.98685 & 103.23485 & 2,923 & 2,733 & -- & 2,459 \\
\hline BRACS-1629 & 30.93716 & 103.12898 & 2,993 & 2,903 & -- & -- \\
\hline BRACS-1630 & 30.95826 & 103.13609 & 2,974 & 2,894 & -- & 2,349 \\
\hline BRACS-1639 & 30.91583 & 103.09555 & 3,038 & 2,943 & -- & 2,394 \\
\hline BRACS-1641 & 31.03361 & 102.39000 & 2,394 & 2,319 & -- & 2,099 \\
\hline BRACS-1642 & 31.04389 & 102.39694 & 2,368 & 2,318 & 2,238 & 2,095 \\
\hline BRACS-1647 & 31.12785 & 102.52808 & 2,386 & 2,325 & -- & 2,164 \\
\hline BRACS-1648 & 31.10293 & 102.58501 & 2,464 & 2,464 & -- & 2,283 \\
\hline BRACS-1650 & 31.00373 & 102.53770 & 2,536 & 2,471 & -- & 2,106 \\
\hline BRACS-1651 & 31.02515 & 102.51900 & 2,453 & 2,363 & -- & 2,062 \\
\hline BRACS-1652 & 30.99661 & 102.54653 & 2,570 & 2,505 & -- & 2,160 \\
\hline BRACS-1654 & 31.09593 & 102.94353 & 2,652 & 2,572 & -- & 2,332 \\
\hline BRACS-1655 & 30.96800 & 102.65588 & 2,726 & 2,726 & -- & 2,567 \\
\hline BRACS-1658 & 30.96743 & 102.57421 & 2,711 & 2,691 & -- & 2,491 \\
\hline BRACS-1659 & 31.04967 & 102.48284 & 2,371 & 2,286 & -- & 2,065 \\
\hline BRACS-1660 & 31.09867 & 102.44283 & 2,327 & 2,274 & -- & 2,075 \\
\hline
\end{tabular}


Table 2. Sites contributing well reports, borehole geophysical logs, and surface geophysical soundings used to determine the lithologies, hydrostratigraphic units, and tops and bases of the hydrostratigraphic units in the Pecos County region study area, Texas.-Continued

$[--$, not used $]$

\begin{tabular}{|c|c|c|c|c|c|c|}
\hline $\begin{array}{c}\text { Site } \\
\text { identifier } \\
\text { (fig. 7) }\end{array}$ & $\begin{array}{c}\text { Latitude } \\
\text { (decimal degrees) }\end{array}$ & $\begin{array}{c}\text { Longitude } \\
\text { (decimal degrees) }\end{array}$ & $\begin{array}{l}\text { Land surface } \\
\text { altitude } \\
\text { (feet) }\end{array}$ & $\begin{array}{l}\text { Altitude of the top } \\
\text { of the Edwards- } \\
\text { Trinity aquifer } \\
\text { (feet) }\end{array}$ & $\begin{array}{c}\text { Altitude of } \\
\text { the top of the } \\
\text { Trinity Group } \\
\text { (feet) }\end{array}$ & $\begin{array}{l}\text { Altitude of the base } \\
\text { of the Edwards- } \\
\text { Trinity aquifer } \\
\text { (feet) }\end{array}$ \\
\hline BRACS-1667 & 30.96458 & 102.28388 & 2,375 & 2,235 & -- & 1,893 \\
\hline BRACS-1669 & 30.98912 & 102.31238 & 2,486 & 2,476 & 2,326 & 2,221 \\
\hline BRACS-1681 & 31.06475 & 103.52950 & 2,876 & 2,876 & 2,651 & 2,456 \\
\hline BRACS-1704 & 30.99439 & 103.67245 & 3,049 & 2,611 & 2,124 & 2,083 \\
\hline BRACS-1705 & 30.98096 & 103.68008 & 3,065 & 2,567 & -- & 1,935 \\
\hline BRACS-1981 & 30.83688 & 102.69043 & 2,951 & 2,829 & 2,711 & 2,561 \\
\hline BRACS-1982 & 31.11386 & 102.53687 & 2,410 & 2,380 & -- & 2,209 \\
\hline BRACS-1984 & 30.93423 & 103.41634 & 3,317 & 3,317 & -- & 2,895 \\
\hline BRACS-1985 & 31.19859 & 102.95412 & 2,581 & 2,561 & 2,561 & 2,315 \\
\hline BRACS-1986 & 31.24079 & 102.97340 & 2,563 & 2,508 & 2,508 & 2,333 \\
\hline BRACS-1992 & 30.80612 & 102.65878 & 3,004 & 3,004 & 2,784 & 2,544 \\
\hline BRACS-1997 & 31.13050 & 102.85201 & 2,589 & 2,519 & 2,419 & 2,199 \\
\hline BRACS-1998 & 30.77326 & 103.51899 & 3,765 & 3,715 & 3,505 & 3,345 \\
\hline BRACS-2002 & 30.98461 & 103.21682 & 2,926 & 2,866 & 2,786 & 2,586 \\
\hline BRACS-2004 & 30.75005 & 103.33497 & 3,433 & 3,433 & 3,158 & 3,043 \\
\hline BRACS-2008 & 30.83654 & 103.45462 & 3,461 & 3,461 & 3,461 & 3,053 \\
\hline BRACS-2010 & 30.86716 & 103.27643 & 3,343 & 3,343 & 3,343 & 2,913 \\
\hline BRACS-2011 & 31.05707 & 102.40528 & 2,345 & 2,223 & 2,105 & 1,985 \\
\hline BRACS-2012 & 30.88377 & 103.23200 & 3,174 & 3,174 & 3,084 & 2,934 \\
\hline BRACS-2015 & 30.73693 & 103.17870 & 3,613 & 3,613 & 3,373 & 3,213 \\
\hline BRACS-2017 & 31.04011 & 102.43908 & 2,407 & -- & -- & 2,097 \\
\hline BRACS-2019 & 31.03129 & 102.26479 & 2,291 & 2,021 & 1,961 & 1,841 \\
\hline BRACS-2020 & 31.22852 & 103.07432 & 2,630 & 2,032 & 2,032 & 1,600 \\
\hline BRACS-2026 & 30.96192 & 103.45549 & 3,085 & 2,995 & 2,995 & 2,875 \\
\hline BRACS-2033 & 31.02639 & 103.38380 & 2,925 & 2,813 & 2,813 & 2,740 \\
\hline BRACS-2037 & 30.98931 & 103.50246 & 3,005 & 2,953 & 2,835 & 2,665 \\
\hline BRACS-2145 & 30.82604 & 103.17534 & 3,216 & 3,164 & 3,046 & 2,966 \\
\hline BRACS-2147 & 31.06344 & 102.45971 & 2,341 & 2,211 & 2,211 & 2,041 \\
\hline BRACS-2150 & 30.70695 & 103.25022 & 3,380 & 3,365 & 3,345 & 3,200 \\
\hline BRACS-2151 & 30.81561 & 102.51381 & 3,245 & -- & -- & 2,705 \\
\hline BRACS-2153 & 31.10459 & 102.96820 & 2,651 & 2,621 & 2,571 & 2,461 \\
\hline BRACS-2154 & 30.97626 & 102.94308 & 2,854 & 2,854 & 2,754 & 2,614 \\
\hline BRACS-2161 & 30.83718 & 102.51338 & 2,805 & 2,805 & 2,755 & 2,580 \\
\hline BRACS-2169 & 31.04222 & 102.43322 & 2,411 & 2,361 & 2,361 & -- \\
\hline BRACS-2182 & 30.84668 & 103.01816 & 3,094 & 3,049 & -- & -- \\
\hline BRACS-2186 & 30.89022 & 102.56684 & 3,033 & 2,763 & 2,763 & 2,583 \\
\hline BRACS-2192 & 31.03419 & 102.96265 & 2,805 & 2,805 & 2,730 & 2,580 \\
\hline BRACS-2194 & 30.87545 & 102.59659 & 2,918 & 2,918 & 2,748 & 2,628 \\
\hline BRACS-2203 & 30.93063 & 103.35175 & 3,119 & 3,112 & 2,994 & 2,844 \\
\hline BRACS-2204 & 30.80490 & 103.53533 & 4,052 & 3,682 & 3,542 & 3,390 \\
\hline BRACS-2206 & 30.86788 & 102.57487 & 2,869 & 2,749 & 2,749 & 2,529 \\
\hline BRACS-2207 & 31.07271 & 102.36447 & 2,291 & 2,201 & 2,161 & 2,051 \\
\hline BRACS-2208 & 30.80653 & 102.76004 & 3,040 & -- & -- & 2,715 \\
\hline BRACS-2210 & 31.17944 & 103.04391 & 2,663 & 2,143 & -- & 1,673 \\
\hline BRACS-2211 & 30.82964 & 102.77051 & 3,118 & 3,118 & 2,868 & 2,713 \\
\hline BRACS-2212 & 30.80104 & 102.75377 & 3,053 & 2,993 & -- & -- \\
\hline
\end{tabular}


Table 2. Sites contributing well reports, borehole geophysical logs, and surface geophysical soundings used to determine the lithologies, hydrostratigraphic units, and tops and bases of the hydrostratigraphic units in the Pecos County region study area, Texas. - Continued

$[--$, not used $]$

\begin{tabular}{|c|c|c|c|c|c|c|}
\hline $\begin{array}{c}\text { Site } \\
\text { identifier } \\
\text { (fig. 7) }\end{array}$ & $\begin{array}{c}\text { Latitude } \\
\text { (decimal degrees) }\end{array}$ & $\begin{array}{c}\text { Longitude } \\
\text { (decimal degrees) }\end{array}$ & $\begin{array}{l}\text { Land surface } \\
\text { altitude } \\
\text { (feet) }\end{array}$ & $\begin{array}{l}\text { Altitude of the top } \\
\text { of the Edwards- } \\
\text { Trinity aquifer } \\
\text { (feet) }\end{array}$ & $\begin{array}{c}\text { Altitude of } \\
\text { the top of the } \\
\text { Trinity Group } \\
\text { (feet) }\end{array}$ & $\begin{array}{l}\text { Altitude of the base } \\
\text { of the Edwards- } \\
\text { Trinity aquifer } \\
\text { (feet) }\end{array}$ \\
\hline BRACS-2222 & 30.76278 & 103.06633 & 3,312 & 3,042 & -- & 2,812 \\
\hline BRACS-2225 & 30.99741 & 102.96687 & 2,832 & 2,832 & 2,736 & 2,502 \\
\hline BRACS-2226 & 30.73992 & 103.06305 & 3,415 & 3,395 & 3,285 & 3,145 \\
\hline BRACS-2230 & 30.73716 & 103.08348 & 3,330 & 3,190 & -- & 2,980 \\
\hline BRACS-2237 & 30.92991 & 102.63428 & 3,113 & 3,113 & -- & 2,961 \\
\hline BRACS-2240 & 30.78615 & 103.46353 & 3,566 & 3,466 & 3,286 & 3,126 \\
\hline BRACS-2247 & 30.64390 & 103.25482 & 3,480 & 3,480 & 3,480 & 3,325 \\
\hline BRACS-2252 & 31.23881 & 103.07869 & 2,619 & 2,049 & 1,964 & 1,554 \\
\hline BRACS-2255 & 31.00500 & 102.21113 & 2,280 & 2,060 & 2,040 & 1,810 \\
\hline BRACS-2258 & 30.71379 & 103.28194 & 3,335 & 3,305 & 3,185 & 3,090 \\
\hline BRACS-2263 & 30.81347 & 102.82316 & 3,155 & 3,155 & -- & 2,855 \\
\hline BRACS-2264 & 31.06550 & 102.40337 & 2,331 & 2,226 & 2,226 & 1,966 \\
\hline BRACS-2265 & 31.07118 & 102.41585 & 2,353 & 2,248 & 2,248 & 1,998 \\
\hline BRACS-2268 & 30.76702 & 103.11723 & 3,451 & 3,451 & 3,321 & 3,096 \\
\hline BRACS-2295 & 30.99133 & 102.67243 & 2,636 & -- & 2,436 & -- \\
\hline BRACS-2313 & 31.12583 & 102.89809 & 2,617 & 2,583 & 2,457 & 2,317 \\
\hline BRACS-2452 & 30.87898 & 102.47309 & 2,716 & 2,716 & 2,556 & 2,406 \\
\hline BRACS-2453 & 30.93657 & 102.58736 & 2,934 & 2,744 & 2,714 & 2,629 \\
\hline BRACS-2454 & 30.96603 & 102.59072 & 2,807 & 2,807 & 2,687 & 2,597 \\
\hline BRACS-2513 & 31.18653 & 102.97079 & 2,607 & 2,347 & -- & 2,107 \\
\hline BRACS-2659 & 30.93602 & 103.67832 & 3,204 & -- & -- & 2,354 \\
\hline BRACS-2660 & 30.93044 & 103.57864 & 3,047 & 2,837 & 2,837 & 2,292 \\
\hline BRACS-2661 & 30.97555 & 103.53611 & 2,980 & 2,951 & -- & 2,434 \\
\hline BRACS-2663 & 30.97917 & 103.55417 & 2,952 & 2,946 & -- & 2,410 \\
\hline BRACS-2664 & 30.96880 & 103.51518 & 3,045 & 3,045 & 2,825 & 2,655 \\
\hline BRACS-2665 & 30.96689 & 103.64024 & 3,018 & -- & 2,426 & 2,028 \\
\hline BRACS-2666 & 30.98029 & 103.57663 & 2,943 & -- & 2,313 & 2,085 \\
\hline BRACS-2668 & 30.93604 & 103.74402 & 3,319 & 2,419 & 2,169 & 1,969 \\
\hline BRACS-2669 & 30.92550 & 103.79484 & 3,406 & 2,956 & 2,956 & 2,446 \\
\hline BRACS-2670 & 30.94163 & 103.66829 & 3,144 & 2,786 & -- & -- \\
\hline BRACS-2744 & 30.96465 & 102.28367 & 2,375 & 2,255 & 1,965 & -- \\
\hline BRACS-2904 & 30.94875 & 103.55675 & 2,998 & 2,836 & -- & 2,271 \\
\hline BRACS-2909 & 30.99887 & 103.16815 & 2,926 & 2,840 & -- & -- \\
\hline BRACS-2910 & 31.07580 & 103.08670 & 2,810 & 2,320 & -- & -- \\
\hline BRACS-2911 & 31.08418 & 103.03573 & 2,779 & 2,422 & -- & 1,919 \\
\hline BRACS-2912 & 31.11792 & 103.11281 & 2,763 & 2,313 & -- & 1,903 \\
\hline BRACS-2913 & 31.14389 & 103.08611 & 2,715 & 2,048 & -- & 1,720 \\
\hline BRACS-2923 & 30.99842 & 103.64334 & 2,991 & 2,361 & -- & 1,925 \\
\hline BRACS-2924 & 30.98840 & 103.62820 & 2,980 & 2,385 & -- & 1,969 \\
\hline BRACS-2926 & 30.99106 & 103.64371 & 2,998 & 2,455 & -- & -- \\
\hline BRACS-2942 & 31.15243 & 103.01463 & 2,684 & 2,346 & -- & 1,955 \\
\hline BRACS-2943 & 31.22802 & 102.96004 & 2,554 & 2,534 & -- & 2,314 \\
\hline BRACS-2945 & 31.20861 & 102.99417 & 2,602 & 2,327 & -- & 2,072 \\
\hline BRACS-2946 & 31.20940 & 102.95644 & 2,564 & -- & -- & -- \\
\hline BRACS-3264 & 30.98361 & 103.44205 & 3,033 & 2,963 & -- & 2,837 \\
\hline DBSA-036 & 30.81761 & 103.27782 & 3,252 & 3,213 & 2,928 & 2,857 \\
\hline
\end{tabular}


Table 2. Sites contributing well reports, borehole geophysical logs, and surface geophysical soundings used to determine the lithologies, hydrostratigraphic units, and tops and bases of the hydrostratigraphic units in the Pecos County region study area, Texas.-Continued

$[--$, not used $]$

\begin{tabular}{|c|c|c|c|c|c|c|}
\hline $\begin{array}{c}\text { Site } \\
\text { identifier } \\
\text { (fig. 7) }\end{array}$ & $\begin{array}{c}\text { Latitude } \\
\text { (decimal degrees) }\end{array}$ & $\begin{array}{c}\text { Longitude } \\
\text { (decimal degrees) }\end{array}$ & $\begin{array}{l}\text { Land surface } \\
\text { altitude } \\
\text { (feet) }\end{array}$ & $\begin{array}{l}\text { Altitude of the top } \\
\text { of the Edwards- } \\
\text { Trinity aquifer } \\
\text { (feet) }\end{array}$ & $\begin{array}{c}\text { Altitude of } \\
\text { the top of the } \\
\text { Trinity Group } \\
\text { (feet) }\end{array}$ & $\begin{array}{l}\text { Altitude of the base } \\
\text { of the Edwards- } \\
\text { Trinity aquifer } \\
\text { (feet) }\end{array}$ \\
\hline DBSA-039 & 30.75100 & 103.16760 & 3,495 & 3,494 & 3,293 & 3,138 \\
\hline DBSA-040 & 30.84284 & 103.02623 & 3,100 & 3,045 & 2,915 & 2,790 \\
\hline DBSA-041 & 30.85833 & 103.02736 & 3,076 & 3,042 & -- & 2,614 \\
\hline DBSA-043 & 30.75471 & 103.06810 & 3,345 & 3,078 & -- & 2,852 \\
\hline DBSA-044 & 30.76306 & 103.00694 & 3,272 & 3,242 & 3,043 & 2,714 \\
\hline DBSA-045 & 30.70377 & 103.24315 & 3,409 & 3,400 & -- & 3,206 \\
\hline DBSA-046 & 30.70718 & 103.25866 & 3,353 & 3,344 & -- & 3,170 \\
\hline DBSA-047 & 30.67946 & 103.21452 & 3,453 & 3,442 & -- & 3,163 \\
\hline DBSA-049 & 30.83185 & 103.19955 & 3,146 & 3,071 & 2,891 & 2,793 \\
\hline DBSA-051 & 30.74283 & 103.07800 & 3,334 & -- & -- & 3,058 \\
\hline DBSA-052 & 30.74267 & 103.08117 & 3,320 & 3,151 & -- & -- \\
\hline DBSA-053 & 30.74524 & 103.00021 & 3,296 & 3,296 & 2,976 & 2,796 \\
\hline DBSA-054 & 30.68197 & 103.12469 & 3,490 & 3,190 & 3,090 & 2,715 \\
\hline DBSA-055 & 30.94478 & 102.94840 & 2,892 & -- & -- & 2,686 \\
\hline DBSA-056 & 30.94498 & 102.93862 & 2,892 & 2,842 & 2,842 & 2,695 \\
\hline DBSA-057 & 30.92335 & 102.93428 & 2,968 & 2,963 & 2,748 & 2,698 \\
\hline DBSA-058 & 30.86957 & 103.00247 & 3,041 & -- & 2,729 & -- \\
\hline DBSA-059 & 30.86610 & 103.04056 & 3,062 & 3,012 & 2,462 & 2,312 \\
\hline DBSA-061 & 30.83043 & 102.95392 & 3,101 & 3,051 & -- & 2,866 \\
\hline DBSA-062 & 30.87479 & 102.90796 & 3,055 & 3,017 & -- & 2,625 \\
\hline DBSA-063 & 30.85412 & 102.90950 & 3,049 & 3,024 & 2,829 & 2,695 \\
\hline DBSA-064 & 30.80139 & 102.99889 & 3,196 & 3,169 & 3,118 & 2,859 \\
\hline DBSA-065 & 30.85642 & 102.90196 & 3,033 & 2,998 & 2,848 & 2,661 \\
\hline DBSA-066 & 30.81876 & 102.88520 & 3,130 & 3,120 & 2,914 & 2,881 \\
\hline DBSA-067 & 30.75770 & 102.90531 & 3,442 & 3,442 & -- & 3,133 \\
\hline DBSA-068 & 30.74312 & 102.91567 & 3,634 & 3,634 & 3,448 & 3,311 \\
\hline DBSA-070 & 30.66601 & 102.90874 & 3,466 & 3,431 & 3,246 & 2,955 \\
\hline DBSA-071 & 30.85766 & 102.97734 & 3,054 & 3,030 & -- & 2,707 \\
\hline DBSA-073 & 30.62451 & 103.14530 & 3,690 & 3,640 & -- & 3,249 \\
\hline DBSA-074 & 30.63910 & 103.06406 & 3,749 & 3,679 & 3,509 & 3,179 \\
\hline DBSA-075 & 30.59485 & 103.02183 & 3,843 & 3,808 & 3,798 & 3,748 \\
\hline DBSA-076 & 30.58608 & 103.12334 & 3,958 & 3,913 & 3,691 & 3,616 \\
\hline DBSA-077 & 30.60114 & 102.97080 & 3,738 & 3,678 & -- & 3,518 \\
\hline DBSA-078 & 30.64638 & 102.96949 & 3,644 & 3,575 & 3,355 & 3,150 \\
\hline DBSA-079 & 30.64589 & 102.88489 & 3,549 & 3,494 & 3,277 & 3,164 \\
\hline DBSA-080 & 30.61599 & 102.86091 & 3,700 & 3,685 & 2,960 & 2,890 \\
\hline DBSA-081 & 30.79969 & 103.03890 & 3,181 & -- & -- & 2,762 \\
\hline DBSA-082 & 30.81505 & 103.02453 & 3,160 & 3,110 & 2,793 & 2,650 \\
\hline DBSA-083 & 30.79855 & 103.01440 & 3,202 & 3,131 & -- & 2,804 \\
\hline DBSA-084 & 30.76344 & 103.04282 & 3,309 & 3,279 & 3,279 & 2,950 \\
\hline DBSA-085 & 30.74792 & 103.05654 & 3,543 & 3,353 & 3,123 & 3,078 \\
\hline DBSA-086 & 30.72105 & 103.15928 & 3,487 & 3,487 & -- & 3,235 \\
\hline DBSA-087 & 30.69572 & 103.02660 & 3,486 & 3,331 & 2,795 & 2,590 \\
\hline DBSA-088 & 30.67661 & 103.02219 & 3,534 & 3,455 & 2,837 & 2,657 \\
\hline DBSA-089 & 30.66518 & 103.04358 & 3,602 & 3,602 & 3,178 & 3,107 \\
\hline DBSA-090 & 30.81608 & 102.96619 & 3,154 & 3,089 & 2,964 & 2,677 \\
\hline
\end{tabular}


Table 2. Sites contributing well reports, borehole geophysical logs, and surface geophysical soundings used to determine the lithologies, hydrostratigraphic units, and tops and bases of the hydrostratigraphic units in the Pecos County region study area, Texas.-Continued

[--, not used]

\begin{tabular}{|c|c|c|c|c|c|c|}
\hline $\begin{array}{c}\text { Site } \\
\text { identifier } \\
\text { (fig. 7) }\end{array}$ & $\begin{array}{c}\text { Latitude } \\
\text { (decimal degrees) }\end{array}$ & $\begin{array}{c}\text { Longitude } \\
\text { (decimal degrees) }\end{array}$ & $\begin{array}{l}\text { Land surface } \\
\text { altitude } \\
\text { (feet) }\end{array}$ & $\begin{array}{l}\text { Altitude of the top } \\
\text { of the Edwards- } \\
\text { Trinity aquifer } \\
\text { (feet) }\end{array}$ & $\begin{array}{c}\text { Altitude of } \\
\text { the top of the } \\
\text { Trinity Group } \\
\text { (feet) }\end{array}$ & $\begin{array}{c}\text { Altitude of the base } \\
\text { of the Edwards- } \\
\text { Trinity aquifer } \\
\text { (feet) }\end{array}$ \\
\hline DBSA-091 & 30.77362 & 102.94773 & 3,398 & 3,388 & 3,198 & 2,962 \\
\hline DBSA-092 & 30.69928 & 102.97718 & 3,479 & 3,479 & 3,094 & 2,706 \\
\hline DBSA-093 & 30.67625 & 102.95187 & 3,504 & 3,483 & 3,074 & 2,745 \\
\hline DBSA-094 & 30.69013 & 102.91888 & 3,396 & 3,201 & 2,809 & 2,636 \\
\hline DBSA-095 & 30.69090 & 102.83673 & 3,309 & 3,257 & 2,772 & 2,646 \\
\hline DBSA-096 & 30.66216 & 102.83509 & 3,409 & 3,239 & 2,939 & 2,774 \\
\hline DBSA-097 & 30.96886 & 103.14349 & 2,967 & 2,890 & -- & 2,462 \\
\hline DBSA-098 & 30.97212 & 103.13810 & 2,964 & 2,906 & -- & 2,483 \\
\hline DBSA-099 & 30.95497 & 103.13222 & 2,972 & 2,876 & 2,500 & 2,334 \\
\hline DBSA-100 & 30.92149 & 103.11474 & 3,008 & 2,918 & -- & 2,338 \\
\hline DBSA-101 & 30.92557 & 103.15312 & 3,015 & 2,985 & -- & 2,536 \\
\hline DBSA-102 & 30.88752 & 103.14824 & 3,078 & 3,002 & 2,603 & 2,565 \\
\hline DBSA-103 & 30.88246 & 103.13142 & 3,075 & 3,005 & 2,625 & 2,535 \\
\hline DBSA-104 & 30.87376 & 103.04722 & 3,045 & 2,975 & 2,466 & 2,335 \\
\hline DBSA-105 & 30.88916 & 103.08508 & 3,062 & 2,977 & 2,762 & 2,542 \\
\hline DBSA-107 & 30.96245 & 102.88053 & 2,879 & 2,795 & 2,683 & 2,557 \\
\hline DBSA-108 & 30.90077 & 102.98753 & 2,979 & 2,929 & 2,699 & 2,509 \\
\hline DBSA-109 & 30.90050 & 102.89341 & 2,980 & 2,900 & -- & 2,610 \\
\hline DBSA-110 & 30.91598 & 102.85998 & 2,919 & 2,859 & 2,751 & 2,630 \\
\hline DBSA-111 & 30.88715 & 103.02782 & 3,006 & 2,981 & -- & 2,484 \\
\hline DBSA-112 & 30.86597 & 103.00654 & 3,048 & -- & 2,822 & -- \\
\hline DBSA-113 & 30.98443 & 103.02628 & 3,034 & 3,034 & 2,654 & 2,537 \\
\hline DBSA-114 & 30.91735 & 103.00551 & 2,999 & 2,999 & -- & 2,554 \\
\hline DBSA-115 & 30.84964 & 103.03246 & 3,090 & 3,040 & 2,842 & 2,707 \\
\hline DBSA-116 & 30.83180 & 103.02364 & 3,124 & 3,054 & 2,944 & 2,829 \\
\hline DBSA-117 & 30.88136 & 102.87716 & 2,941 & 2,941 & 2,681 & 2,625 \\
\hline DBSA-118 & 30.85433 & 102.88516 & 3,002 & 2,982 & 2,897 & 2,685 \\
\hline DBSA-119 & 30.86818 & 102.92472 & 3,086 & 3,086 & 2,806 & 2,704 \\
\hline DBSA-120 & 30.85843 & 102.99702 & 3,062 & 3,012 & 2,782 & 2,659 \\
\hline DBSA-121 & 30.84515 & 102.99178 & 3,083 & 3,058 & -- & 2,797 \\
\hline DBSA-124 & 30.91430 & 103.03516 & 3,206 & 3,206 & 2,996 & 2,486 \\
\hline DBSA-125 & 30.89546 & 103.02813 & 3,046 & 3,046 & 2,736 & 2,576 \\
\hline DBSA-126 & 30.85354 & 103.05756 & 3,095 & 3,040 & 2,940 & 2,530 \\
\hline DBSA-127 & 30.88081 & 103.01438 & 3,008 & 2,988 & 2,827 & 2,559 \\
\hline DBSA-128 & 30.87188 & 103.00596 & 3,039 & 2,979 & -- & 2,578 \\
\hline DBSA-130 & 30.86300 & 103.02164 & 3,064 & 2,990 & -- & 2,559 \\
\hline DBSA-131 & 30.86755 & 103.03802 & 3,061 & 2,987 & -- & -- \\
\hline DBSA-132 & 30.84495 & 103.01109 & 3,096 & -- & 2,872 & -- \\
\hline DBSA-133 & 30.78701 & 103.05560 & 3,205 & 3,187 & -- & 2,869 \\
\hline DBSA-134 & 30.78707 & 103.05347 & 3,206 & 3,176 & -- & 2,855 \\
\hline DBSA-136 & 30.88515 & 102.79960 & 2,973 & 2,943 & 2,788 & 2,493 \\
\hline DBSA-137 & 30.80919 & 102.96216 & 3,183 & 3,113 & 3,006 & 2,773 \\
\hline DBSA-138 & 30.96679 & 102.85950 & 2,862 & 2,792 & -- & 2,517 \\
\hline DBSA-139 & 30.90253 & 102.87825 & 2,961 & -- & 2,683 & 2,586 \\
\hline DBSA-140 & 30.90572 & 102.93458 & 3,081 & 3,081 & 2,760 & 2,641 \\
\hline DBSA-141 & 30.89308 & 102.93134 & 3,122 & -- & -- & 2,594 \\
\hline
\end{tabular}


Table 2. Sites contributing well reports, borehole geophysical logs, and surface geophysical soundings used to determine the lithologies, hydrostratigraphic units, and tops and bases of the hydrostratigraphic units in the Pecos County region study area, Texas. - Continued

$[--$, not used $]$

\begin{tabular}{|c|c|c|c|c|c|c|}
\hline $\begin{array}{c}\text { Site } \\
\text { identifier } \\
\text { (fig. 7) }\end{array}$ & $\begin{array}{c}\text { Latitude } \\
\text { (decimal degrees) }\end{array}$ & $\begin{array}{c}\text { Longitude } \\
\text { (decimal degrees) }\end{array}$ & $\begin{array}{l}\text { Land surface } \\
\text { altitude } \\
\text { (feet) }\end{array}$ & $\begin{array}{l}\text { Altitude of the top } \\
\text { of the Edwards- } \\
\text { Trinity aquifer } \\
\text { (feet) }\end{array}$ & $\begin{array}{c}\text { Altitude of } \\
\text { the top of the } \\
\text { Trinity Group } \\
\text { (feet) }\end{array}$ & $\begin{array}{l}\text { Altitude of the base } \\
\text { of the Edwards- } \\
\text { Trinity aquifer } \\
\text { (feet) }\end{array}$ \\
\hline DBSA-142 & 30.88351 & 102.92979 & 3,142 & 2,997 & 2,718 & 2,524 \\
\hline DBSA-143 & 30.88857 & 102.89481 & 3,004 & 2,939 & 2,718 & 2,591 \\
\hline DBSA-144 & 30.89213 & 102.88336 & 2,980 & 2,966 & 2,720 & 2,632 \\
\hline DBSA-145 & 30.90148 & 102.85575 & 2,921 & 2,886 & 2,813 & 2,646 \\
\hline DBSA-146 & 30.91087 & 102.82786 & 2,897 & 2,867 & 2,737 & 2,551 \\
\hline DBSA-147 & 30.88935 & 102.83192 & 2,971 & 2,811 & 2,561 & 2,461 \\
\hline DBSA-148 & 30.86527 & 102.88777 & 2,984 & 2,964 & 2,874 & 2,584 \\
\hline DBSA-149 & 30.86559 & 102.88877 & 2,989 & 2,971 & -- & 2,593 \\
\hline DBSA-150 & 30.91333 & 103.17722 & 3,039 & 3,004 & -- & 2,647 \\
\hline DBSA-151 & 30.68389 & 103.45111 & 3,722 & 3,672 & 3,292 & 3,122 \\
\hline DBSA-152 & 30.70000 & 103.41444 & 3,604 & 3,514 & -- & 3,099 \\
\hline DBSA-153 & 30.72667 & 103.33333 & 3,376 & 3,376 & -- & 3,060 \\
\hline DBSA-154 & 30.72722 & 103.33389 & 3,371 & 3,371 & -- & 3,053 \\
\hline DBSA-155 & 30.72750 & 103.33500 & 3,368 & 3,368 & -- & 3,047 \\
\hline DBSA-156 & 30.65444 & 103.35472 & 3,567 & 3,483 & -- & 3,323 \\
\hline DBSA-157 & 30.63556 & 103.30806 & 3,442 & 3,433 & -- & 3,282 \\
\hline DBSA-158 & 30.63194 & 103.16306 & 3,640 & 3,625 & -- & 3,264 \\
\hline DBSA-161 & 30.57083 & 103.20500 & 3,927 & 3,908 & 3,766 & 3,671 \\
\hline DBSA-163 & 30.97472 & 102.89028 & 2,873 & 2,859 & -- & 2,626 \\
\hline DBSA-164 & 30.95361 & 102.87889 & 2,877 & 2,860 & 2,753 & 2,627 \\
\hline DBSA-165 & 30.95806 & 102.89611 & 2,882 & 2,792 & 2,697 & 2,577 \\
\hline DBSA-166 & 30.87639 & 102.98972 & 3,030 & 2,950 & 2,830 & 2,556 \\
\hline DBSA-167 & 30.89806 & 102.93194 & 3,103 & 3,103 & 2,778 & 2,611 \\
\hline DBSA-168 & 30.88472 & 102.90972 & 3,061 & 3,019 & -- & 2,615 \\
\hline DBSA-169 & 30.87667 & 102.89028 & 3,000 & 2,920 & 2,800 & 2,556 \\
\hline DBSA-171 & 30.90500 & 102.89111 & 2,968 & 2,890 & -- & 2,585 \\
\hline DBSA-172 & 30.96194 & 102.84889 & 2,830 & 2,760 & 2,751 & 2,478 \\
\hline DBSA-173 & 30.90611 & 102.83806 & 2,914 & 2,784 & 2,744 & 2,495 \\
\hline DBSA-174 & 30.87278 & 102.90667 & 3,051 & 2,993 & -- & 2,606 \\
\hline DBSA-175 & 30.77306 & 102.90194 & 3,340 & 3,328 & -- & 3,043 \\
\hline DBSA-176 & 30.85667 & 102.77806 & 3,053 & 3,053 & -- & 2,666 \\
\hline DBSA-177 & 30.84517 & 102.99220 & 3,083 & 3,062 & -- & 2,803 \\
\hline DBSA-178 & 30.84512 & 102.99756 & 3,088 & 3,067 & -- & -- \\
\hline DBSA-179 & 30.83006 & 102.97460 & 3,100 & 3,025 & 2,884 & 2,735 \\
\hline DBSA-181 & 31.02009 & 103.26006 & 2,897 & 2,617 & 2,517 & 2,412 \\
\hline DBSA-182 & 31.00726 & 103.32115 & 2,952 & 2,837 & 2,667 & 2,507 \\
\hline DBSA-183 & 31.06246 & 103.31201 & 2,863 & 2,733 & 2,578 & 2,418 \\
\hline DBSA-184 & 30.98268 & 103.32626 & 3,004 & 2,794 & 2,674 & 2,554 \\
\hline DBSA-188 & 30.80170 & 103.03060 & 3,188 & 3,133 & 2,768 & -- \\
\hline DBSA-189 & 30.80810 & 103.04360 & 3,159 & 2,967 & 2,697 & 2,583 \\
\hline DBSA-190 & 30.78920 & 103.02780 & 3,219 & 3,169 & -- & 2,837 \\
\hline DBSA-191 & 30.78780 & 103.02670 & 3,223 & 3,158 & -- & 2,829 \\
\hline DBSA-193 & 30.78833 & 103.00167 & 3,250 & 3,170 & -- & 2,874 \\
\hline DBSA-197 & 30.74310 & 103.21396 & 3,433 & 3,433 & -- & 3,091 \\
\hline DBSA-199 & 30.72045 & 103.16864 & 3,578 & 3,578 & 3,483 & 3,326 \\
\hline DBSA-200 & 30.71839 & 103.16225 & 3,493 & 3,493 & -- & 3,259 \\
\hline
\end{tabular}


Table 2. Sites contributing well reports, borehole geophysical logs, and surface geophysical soundings used to determine the lithologies, hydrostratigraphic units, and tops and bases of the hydrostratigraphic units in the Pecos County region study area, Texas. - Continued

$[--$, not used $]$

\begin{tabular}{|c|c|c|c|c|c|c|}
\hline $\begin{array}{c}\text { Site } \\
\text { identifier } \\
\text { (fig. 7) }\end{array}$ & $\begin{array}{c}\text { Latitude } \\
\text { (decimal degrees) }\end{array}$ & $\begin{array}{c}\text { Longitude } \\
\text { (decimal degrees) }\end{array}$ & $\begin{array}{l}\text { Land surface } \\
\text { altitude } \\
\text { (feet) }\end{array}$ & $\begin{array}{l}\text { Altitude of the top } \\
\text { of the Edwards- } \\
\text { Trinity aquifer } \\
\text { (feet) }\end{array}$ & $\begin{array}{c}\text { Altitude of } \\
\text { the top of the } \\
\text { Trinity Group } \\
\text { (feet) }\end{array}$ & $\begin{array}{l}\text { Altitude of the base } \\
\text { of the Edwards- } \\
\text { Trinity aquifer } \\
\text { (feet) }\end{array}$ \\
\hline DBSA-201 & 30.71925 & 103.16655 & 3,540 & 3,540 & -- & 3,305 \\
\hline DBSA-203 & 30.75199 & 102.97328 & 3,400 & 3,360 & 3,211 & 2,870 \\
\hline DBSA-204 & 30.64366 & 103.16820 & 3,588 & 3,518 & -- & 3,159 \\
\hline DBSA-205 & 30.69429 & 103.06752 & 3,538 & 3,538 & 3,181 & 2,814 \\
\hline DBSA-208 & 30.77372 & 102.94765 & 3,395 & 3,385 & 3,195 & 2,955 \\
\hline DBSA-210 & 30.71609 & 103.16714 & 3,510 & 3,510 & 3,434 & -- \\
\hline DBSA-211 & 30.72922 & 103.11029 & 3,322 & 3,237 & -- & 2,922 \\
\hline DBSA-212 & 30.65791 & 103.09612 & 3,715 & 3,715 & 3,487 & 3,030 \\
\hline DBSA-214 & 30.70229 & 103.06421 & 3,536 & 3,536 & 3,098 & 2,843 \\
\hline DBSA-216 & 30.73513 & 103.18741 & 3,574 & 3,574 & 3,452 & 3,189 \\
\hline DBSA-217 & 30.72077 & 103.20475 & 3,601 & 3,601 & -- & 3,237 \\
\hline DBSA-218 & 30.79551 & 102.96050 & 3,244 & 3,104 & 2,969 & 2,774 \\
\hline DBSA-220 & 30.70713 & 103.19519 & 3,591 & 3,591 & 3,301 & 3,181 \\
\hline DBSA-223 & 30.88088 & 103.40379 & 3,301 & 3,301 & -- & 3,076 \\
\hline DBSA-224 & 30.77515 & 103.42563 & 3,590 & 3,590 & 3,412 & 3,271 \\
\hline DBSA-228 & 30.98683 & 103.23491 & 2,923 & 2,734 & -- & 2,460 \\
\hline DBSA-229 & 30.89575 & 103.12843 & 3,056 & 3,042 & 2,620 & 2,551 \\
\hline DBSA-230 & 31.02881 & 102.90003 & 2,731 & 2,706 & 2,706 & 2,453 \\
\hline DBSA-231 & 31.04620 & 102.89913 & 2,782 & 2,782 & 2,782 & 2,517 \\
\hline DBSA-251 & 30.90939 & 102.87435 & 2,944 & -- & 2,729 & -- \\
\hline DBSA-255 & 30.91918 & 102.86270 & 2,918 & 2,838 & 2,763 & 2,623 \\
\hline DBSA-256 & 30.91525 & 102.85698 & 2,919 & 2,859 & 2,779 & 2,626 \\
\hline DBSA-257 & 30.88119 & 102.85087 & 2,993 & 2,903 & 2,823 & 2,707 \\
\hline DBSA-258 & 30.88677 & 102.86808 & 2,929 & -- & 2,759 & -- \\
\hline DBSA-259 & 30.88166 & 102.84805 & 2,996 & 2,906 & 2,806 & -- \\
\hline DBSA-260 & 30.88135 & 102.84943 & 2,994 & 2,904 & 2,827 & 2,706 \\
\hline DBSA-261 & 30.88140 & 102.85122 & 2,992 & 2,902 & -- & 2,707 \\
\hline DBSA-265 & 30.90828 & 102.87469 & 2,947 & -- & 2,732 & -- \\
\hline DBSA-310 & 31.09256 & 103.04454 & 2,784 & -- & 2,103 & -- \\
\hline DBSA-311 & 31.08878 & 103.09438 & 2,787 & 2,512 & 2,274 & -- \\
\hline DBSA-312 & 31.05870 & 102.80656 & 2,624 & 2,581 & 2,521 & 2,337 \\
\hline DBSA-313 & 30.91173 & 103.00093 & 2,995 & 2,945 & 2,715 & 2,525 \\
\hline DBSA-314 & 30.93779 & 103.43380 & 3,326 & 3,326 & 3,036 & 2,916 \\
\hline DBSA-315 & 30.93127 & 103.40476 & 3,261 & 3,261 & 2,941 & 2,821 \\
\hline DBSA-316 & 30.87068 & 103.26405 & 3,336 & 3,336 & 2,956 & 2,876 \\
\hline DBSA-318 & 30.85440 & 103.01811 & 3,074 & -- & 2,834 & -- \\
\hline DBSA-320 & 30.81678 & 102.81948 & 3,164 & 3,164 & -- & -- \\
\hline DBSA-322 & 30.81955 & 102.65095 & 2,970 & 2,970 & -- & 2,537 \\
\hline DBSA-324 & 31.01231 & 103.33244 & 2,944 & -- & 2,804 & 2,684 \\
\hline DBSA-325 & 30.99298 & 103.30716 & 2,975 & 2,925 & 2,825 & 2,705 \\
\hline DBSA-326 & 30.98358 & 103.28544 & 2,970 & 2,886 & 2,777 & 2,642 \\
\hline DBSA-327 & 31.01290 & 103.26838 & 2,913 & 2,803 & 2,623 & 2,533 \\
\hline DBSA-328 & 31.02781 & 103.25969 & 2,886 & 2,626 & 2,516 & 2,416 \\
\hline DBSA-329 & 31.03164 & 103.24734 & 2,870 & 2,590 & 2,390 & 2,290 \\
\hline DBSA-330 & 30.77244 & 102.85862 & 3,281 & 3,231 & 3,063 & 2,931 \\
\hline DBSA-331 & 30.77541 & 102.80033 & 3,118 & 3,048 & 2,893 & 2,677 \\
\hline
\end{tabular}


Table 2. Sites contributing well reports, borehole geophysical logs, and surface geophysical soundings used to determine the lithologies, hydrostratigraphic units, and tops and bases of the hydrostratigraphic units in the Pecos County region study area, Texas.-Continued

$[--$, not used $]$

\begin{tabular}{|c|c|c|c|c|c|c|}
\hline $\begin{array}{c}\text { Site } \\
\text { identifier } \\
\text { (fig. 7) }\end{array}$ & $\begin{array}{c}\text { Latitude } \\
\text { (decimal degrees) }\end{array}$ & $\begin{array}{c}\text { Longitude } \\
\text { (decimal degrees) }\end{array}$ & $\begin{array}{l}\text { Land surface } \\
\text { altitude } \\
\text { (feet) }\end{array}$ & $\begin{array}{l}\text { Altitude of the top } \\
\text { of the Edwards- } \\
\text { Trinity aquifer } \\
\text { (feet) }\end{array}$ & $\begin{array}{c}\text { Altitude of } \\
\text { the top of the } \\
\text { Trinity Group } \\
\text { (feet) }\end{array}$ & $\begin{array}{l}\text { Altitude of the base } \\
\text { of the Edwards- } \\
\text { Trinity aquifer } \\
\text { (feet) }\end{array}$ \\
\hline DBSA-333 & 30.79551 & 102.77492 & 3,070 & 3,050 & 2,822 & 2,670 \\
\hline DBSA-334 & 30.85935 & 103.47376 & 3,421 & 3,421 & 2,961 & 2,896 \\
\hline DBSA-335 & 30.99862 & 103.16741 & 2,925 & -- & 2,564 & 2,425 \\
\hline RRC-4237130439 & 30.90436 & 102.92809 & 3,081 & -- & -- & 2,631 \\
\hline RRC-4237130512 & 30.96859 & 102.25849 & 2,377 & 2,377 & 2,307 & 2,157 \\
\hline RRC-4237130938 & 30.67648 & 103.05709 & 3,520 & -- & 3,250 & 3,120 \\
\hline RRC-4237134760 & 30.86302 & 102.93169 & 3,059 & -- & -- & 2,694 \\
\hline RRC-4237134898 & 30.90304 & 102.32704 & 2,527 & 2,492 & -- & 2,297 \\
\hline RRC-4237134909 & 30.89240 & 102.31876 & 2,648 & 2,628 & 2,553 & -- \\
\hline RRC-4237135042 & 30.88697 & 102.31262 & 2,571 & -- & 2,441 & 2,301 \\
\hline RRC-4237136582 & 30.99401 & 102.41091 & 2,560 & 2,508 & 2,390 & 2,240 \\
\hline RRC-4237136860 & 30.53832 & 102.91787 & 4,056 & 3,964 & 3,846 & 3,666 \\
\hline RRC-4237137144 & 30.81913 & 102.39868 & 3,233 & 3,113 & 3,103 & 2,898 \\
\hline RRC-4237137145D1 & 30.97233 & 102.99202 & 2,905 & 2,853 & 2,735 & 2,585 \\
\hline RRC-4237137149 & 30.79113 & 102.36360 & 3,244 & 2,979 & 2,844 & 2,684 \\
\hline RRC-4237137184 & 30.98321 & 102.95896 & 2,827 & -- & -- & 2,377 \\
\hline RRC-4237137192 & 30.81190 & 102.42367 & 2,866 & 2,866 & 2,606 & 2,451 \\
\hline RRC-4237137193 & 31.21404 & 102.93741 & 2,541 & -- & 2,321 & 2,171 \\
\hline RRC-4237137219 & 31.08091 & 102.78678 & 2,564 & 2,392 & -- & 2,104 \\
\hline RRC-4237137222 & 30.95380 & 102.41601 & 2,936 & 2,736 & 2,736 & 2,332 \\
\hline RRC-4237137226H1 & 31.02169 & 102.94414 & 2,821 & 2,769 & 2,651 & 2,501 \\
\hline RRC-4237137249 & 30.83260 & 102.46539 & 2,740 & 2,740 & 2,710 & 2,560 \\
\hline RRC-4237137308 & 31.02083 & 102.92737 & 2,854 & -- & 2,524 & 2,424 \\
\hline RRC-4237137343 & 31.00069 & 102.91066 & 2,792 & 2,792 & 2,682 & 2,532 \\
\hline RRC-4237137344 & 31.00180 & 102.93251 & 2,806 & 2,736 & 2,691 & 2,506 \\
\hline RRC-4237137345 & 30.98513 & 102.91801 & 2,813 & 2,813 & 2,703 & 2,553 \\
\hline RRC-4237137346 & 30.98643 & 102.92052 & 2,815 & 2,815 & 2,705 & 2,555 \\
\hline RRC-4237137348 & 30.98543 & 102.94906 & 2,838 & 2,696 & 2,578 & 2,388 \\
\hline RRC-4237137404 & 30.44705 & 102.91642 & 4,391 & 4,306 & -- & 4,111 \\
\hline RRC-4237137420 & 31.18497 & 103.01739 & 2,641 & 2,371 & 2,361 & -- \\
\hline RRC-4237137425 & 30.43616 & 102.80653 & 4,203 & 4,161 & 4,043 & 3,823 \\
\hline RRC-4237137432 & 30.94433 & 102.40882 & 2,631 & 2,631 & 2,631 & 2,331 \\
\hline RRC-4237137440 & 31.20530 & 103.07624 & 2,656 & 2,026 & 2,026 & 1,636 \\
\hline RRC-4237137476 & 31.00547 & 102.93700 & 2,806 & -- & 2,696 & -- \\
\hline RRC-4237137512 & 30.47826 & 102.80501 & 4,088 & 3,774 & 3,683 & 3,605 \\
\hline RRC-4237137513 & 30.97139 & 102.46972 & 2,633 & 2,633 & 2,443 & 2,273 \\
\hline RRC-4237137521 & 31.22954 & 102.95019 & 2,547 & 2,547 & 2,447 & -- \\
\hline RRC-4237137546 & 31.08070 & 102.78273 & 2,560 & -- & -- & 2,090 \\
\hline RRC-4237137549 & 30.79703 & 102.48402 & 2,986 & 2,986 & 2,926 & 2,694 \\
\hline RRC-4237137552 & 30.80645 & 102.49553 & 2,983 & 2,921 & -- & 2,613 \\
\hline RRC-4237137563 & 30.77833 & 102.47648 & 3,350 & 3,350 & 3,100 & 2,940 \\
\hline RRC-4237137659 & 31.05036 & 102.78674 & 2,615 & 2,450 & 2,335 & 2,180 \\
\hline RRC-4237137690 & 31.18991 & 102.83923 & 2,475 & 2,440 & -- & 2,145 \\
\hline RRC-4237137769 & 30.97606 & 102.47663 & 2,574 & 2,542 & 2,424 & 2,274 \\
\hline RRC-4237137896 & 30.93913 & 102.97209 & 2,899 & 2,837 & 2,719 & -- \\
\hline RRC-4237137898 & 30.92596 & 102.92080 & 2,957 & 2,860 & 2,742 & 2,592 \\
\hline
\end{tabular}


Table 2. Sites contributing well reports, borehole geophysical logs, and surface geophysical soundings used to determine the lithologies, hydrostratigraphic units, and tops and bases of the hydrostratigraphic units in the Pecos County region study area, Texas. - Continued

$[--$, not used $]$

\begin{tabular}{|c|c|c|c|c|c|c|}
\hline $\begin{array}{c}\text { Site } \\
\text { identifier } \\
\text { (fig. 7) }\end{array}$ & $\begin{array}{c}\text { Latitude } \\
\text { (decimal degrees) }\end{array}$ & $\begin{array}{c}\text { Longitude } \\
\text { (decimal degrees) }\end{array}$ & $\begin{array}{l}\text { Land surface } \\
\text { altitude } \\
\text { (feet) }\end{array}$ & $\begin{array}{l}\text { Altitude of the top } \\
\text { of the Edwards- } \\
\text { Trinity aquifer } \\
\text { (feet) }\end{array}$ & $\begin{array}{c}\text { Altitude of } \\
\text { the top of the } \\
\text { Trinity Group } \\
\text { (feet) }\end{array}$ & $\begin{array}{l}\text { Altitude of the base } \\
\text { of the Edwards- } \\
\text { Trinity aquifer } \\
\text { (feet) }\end{array}$ \\
\hline RRC-4237137899 & 30.95065 & 102.95198 & 2,884 & 2,844 & 2,844 & 2,674 \\
\hline RRC-4237137943 & 31.19705 & 103.00962 & 2,623 & 2,316 & 2,198 & 1,993 \\
\hline RRC-4237137947 & 31.04948 & 102.67692 & 2,550 & 2,435 & 2,435 & 2,285 \\
\hline RRC-4237138229 & 30.97959 & 102.89657 & 2,861 & -- & -- & 2,623 \\
\hline RRC-4237138416 & 30.87378 & 102.48960 & 2,678 & 2,496 & 2,378 & 2,228 \\
\hline RRC-4237138566 & 30.99109 & 102.39304 & 2,559 & -- & -- & 2,154 \\
\hline RRC-4237138567 & 31.00559 & 102.39790 & 2,543 & 2,447 & -- & 2,163 \\
\hline RRC-4237138635 & 31.00456 & 102.39528 & 2,520 & 2,428 & -- & -- \\
\hline RRC-4237138636 & 30.99320 & 102.39055 & 2,540 & -- & -- & 2,170 \\
\hline USGS-AMT01 & 30.57745 & 103.28333 & 3,649 & 3,492 & -- & 3,266 \\
\hline USGS-AMT02 & 30.51932 & 103.30687 & 3,794 & 3,499 & 3,422 & 3,289 \\
\hline USGS-AMT03 & 30.71023 & 103.52157 & 3,725 & 3,485 & 3,314 & 3,157 \\
\hline USGS-AMT04 & 30.88350 & 103.38389 & 3,278 & 2,986 & -- & 2,884 \\
\hline USGS-AMT05 & 30.80659 & 103.48194 & 3,646 & 3,364 & -- & 3,200 \\
\hline USGS-AMT06 & 30.60335 & 102.78842 & 3,536 & 3,280 & -- & 2,706 \\
\hline USGS-AMT09 & 31.06002 & 103.13731 & 2,841 & 2,707 & 2,677 & 2,582 \\
\hline USGS-AMT10 & 30.94134 & 102.55057 & 2,888 & 2,623 & -- & 2,409 \\
\hline USGS-AMT13 & 30.86516 & 103.82792 & 3,659 & 3,560 & 3,553 & 3,409 \\
\hline UTL-4237100408 & 30.85729 & 102.33328 & 2,702 & 2,602 & 2,562 & 2,352 \\
\hline UTL-4237100624 & 30.91815 & 102.37499 & 2,491 & 2,476 & 2,476 & 2,261 \\
\hline UTL-4237100629 & 30.88577 & 102.30522 & 2,562 & -- & 2,482 & 2,302 \\
\hline UTL-4237100632 & 30.91466 & 102.40170 & 2,564 & 2,564 & 2,564 & 2,430 \\
\hline UTL-4237100760 & 30.91809 & 102.21097 & 2,963 & -- & 2,707 & 2,558 \\
\hline UTL-4237101084 & 30.96110 & 102.21109 & 2,495 & 2,495 & 2,375 & 2,225 \\
\hline UTL-4237101169 & 30.89871 & 102.32453 & 2,593 & -- & 2,483 & -- \\
\hline UTL-4237101303 & 30.90291 & 102.43366 & 2,682 & 2,682 & 2,572 & 2,472 \\
\hline UTL-4237101376 & 31.00633 & 102.70556 & 2,627 & 2,480 & 2,377 & 2,307 \\
\hline UTL-4237101391 & 30.91191 & 102.41052 & 2,613 & 2,613 & 2,613 & 2,455 \\
\hline UTL-4237102196 & 30.93593 & 102.42189 & 2,626 & 2,626 & 2,596 & 2,446 \\
\hline UTL-4237104143 & 30.89737 & 102.67229 & 3,002 & 2,980 & 2,862 & 2,782 \\
\hline UTL-4237104725 & 30.93361 & 102.65531 & 3,113 & 3,093 & 3,093 & 2,943 \\
\hline UTL-4237110713 & 30.92267 & 102.63851 & 3,088 & 3,088 & 3,088 & 2,935 \\
\hline UTL-4237110836 & 30.83082 & 102.57477 & 2,808 & 2,808 & -- & 2,568 \\
\hline UTL-4237111117 & 30.92991 & 102.63428 & 3,113 & 3,113 & 3,113 & 2,961 \\
\hline UTL-4237111280 & 30.91496 & 102.67222 & 2,939 & 2,929 & -- & 2,756 \\
\hline UTL-4237111415 & 30.94856 & 102.62639 & 2,787 & 2,787 & 2,787 & 2,617 \\
\hline UTL-4237130857 & 30.80820 & 102.59066 & 2,857 & 2,857 & 2,832 & 2,675 \\
\hline UTL-4237132468 & 30.83847 & 102.65610 & 2,937 & 2,937 & 2,804 & 2,497 \\
\hline UTL-4237132640 & 30.86691 & 102.64927 & 2,858 & 2,728 & 2,668 & 2,468 \\
\hline UTL-4237132819 & 30.94366 & 102.35298 & 2,504 & 2,504 & 2,454 & 2,274 \\
\hline UTL-4237133557 & 30.77395 & 102.66017 & 3,104 & 2,944 & 2,769 & 2,594 \\
\hline UTL-4237133677 & 30.85197 & 102.65775 & 2,880 & 2,808 & 2,650 & 2,480 \\
\hline UTL-4237134344 & 30.86660 & 102.69992 & 3,075 & 2,804 & 2,804 & 2,582 \\
\hline UTL-4237134536 & 30.88957 & 102.70809 & 2,899 & 2,789 & 2,724 & 2,619 \\
\hline UTL-4237135055 & 30.88176 & 102.70735 & 2,906 & 2,786 & 2,711 & 2,604 \\
\hline UTL-4237136157 & 30.99542 & 102.69718 & 2,646 & 2,516 & 2,471 & 2,356 \\
\hline
\end{tabular}


Table 3. Location of geophysical soundings and the nearby borehole geophysical log the sounding was compared to in the Pecos County region study area, Texas.

[TDEM, time-domain electromagnetic sounding; AMT, audio-magnetotelluric sounding; USGS, U.S. Geological Survey]

\begin{tabular}{cccccc}
\hline $\begin{array}{c}\text { Sounding } \\
\text { identifier }\end{array}$ & $\begin{array}{c}\text { Latitude } \\
\text { (decimal degrees) }\end{array}$ & $\begin{array}{c}\text { Longitude } \\
\text { (decimal degrees) }\end{array}$ & $\begin{array}{c}\text { USGS station number } \\
\text { for borehole log } \\
\text { comparison }\end{array}$ & $\begin{array}{c}\text { Latitude } \\
\text { (decimal degrees) }\end{array}$ & $\begin{array}{c}\text { Longitude } \\
\text { (decimal degrees) }\end{array}$ \\
\hline TDEM1 & 30.85286 & 102.89278 & 310221102534201 & 30.85286 & 102.89278 \\
TDEM2 & 30.84514 & 102.99889 & 305042102595601 & 30.84509 & 102.99899 \\
TDEM3 & 30.78642 & 103.00917 & 304711103003301 & 30.78642 & 103.00932 \\
TDEM4 & 30.64000 & 102.48028 & 303824102285001 & 30.64000 & 102.48052 \\
AMT07 & 30.64030 & 102.47209 & 303824102285001 & 30.64000 & 102.48052 \\
AMT08 & 30.44190 & 102.84390 & 302630102503801 & 30.44176 & 30.77304 \\
AMT11 & 30.77301 & 102.52359 & 304622102312401 & 31.13502 & 102.84396 \\
AMT12 & 31.13473 & 103.29427 & 310806103171901 & 103.28796 \\
\hline
\end{tabular}


Table 4. Compiled transmissivity values using data from aquifer tests conducted at wells completed in the Edwards-Trinity aquifer in or near the Pecos County region study area, Texas.

[Trans., transmissivity; [(gal/d)/ft], gallons per day per foot; [(gal/d)/ft² $]$, gallons per day per square foot; --, not available; JMF, Jacob modified formula; TNEF, Theis nonequilibrium formula; TRF, Theis recovery formula; DF, Driscoll's formula; USGS, U.S. Geological Survey; TWDB, Texas Water Development Board]

\begin{tabular}{|c|c|c|c|c|c|c|c|c|c|c|c|}
\hline $\begin{array}{c}\text { Site } \\
\text { identi- } \\
\text { fier } \\
\text { (fig. 19) }\end{array}$ & $\begin{array}{c}\text { TWDB } \\
\text { well } \\
\text { number }\end{array}$ & $\begin{array}{c}\text { Source } \\
\text { site } \\
\text { name }\end{array}$ & $\begin{array}{c}\text { Year } \\
\text { of data } \\
\text { collec- } \\
\text { tion }\end{array}$ & $\begin{array}{l}\text { Latitude } \\
\text { (decimal } \\
\text { degrees) }\end{array}$ & $\begin{array}{l}\text { Longitude } \\
\text { (decimal } \\
\text { degrees) }\end{array}$ & $\begin{array}{c}\text { Trans. } \\
{[(\text { gal/d)/ft] }}\end{array}$ & $\begin{array}{c}\text { Aquifer } \\
\text { thick- } \\
\text { ness } \\
\text { (feet) }\end{array}$ & $\begin{array}{l}\text { Hydraulic } \\
\text { conductivity } \\
{\left[(\mathrm{gal} / \mathrm{d}) / \mathrm{ft}^{2}\right]}\end{array}$ & $\begin{array}{l}\text { Log of } \\
\text { Trans. } \\
\text { value }\end{array}$ & Method & Source \\
\hline $\mathrm{T} 1$ & -- & M-3 & 2009 & 30.76829 & 103.02616 & $1,078,000$ & 1,202 & 8,900 & 13.891 & JMF & Thornhill Group, Inc., 2009 \\
\hline $\mathrm{T} 2$ & -- & M-9 & 2009 & 30.77201 & 103.02618 & 726,000 & 1,201 & 6,050 & 13.685 & JMF & Thornhill Group, Inc., 2009 \\
\hline $\mathrm{T} 3$ & -- & $\begin{array}{l}\text { CITY } \\
\text { No. } 5\end{array}$ & 2009 & 30.77221 & 103.03584 & 755,000 & 2,202 & 3,400 & 13.891 & JMF & Thornhill Group, Inc., 2009 \\
\hline $\mathrm{T} 4$ & -- & S-4 & 2009 & 30.82763 & 103.04356 & 363,000 & 3,402 & 1,060 & 14.737 & JMF & Thornhill Group, Inc., 2009 \\
\hline T5 & -- & $\mathrm{S}-3$ & 2009 & 30.82737 & 103.04354 & 389,000 & 3,301 & 1,200 & 14.166 & JMF & Thornhill Group, Inc., 2009 \\
\hline $\mathrm{T} 6$ & -- & S-10 & 2009 & 30.83067 & 103.02697 & $1,017,000$ & 1,902 & 5,300 & 13.832 & JMF & Thornhill Group, Inc., 2009 \\
\hline $\mathrm{T} 7$ & -- & S-32 & 2009 & 30.85885 & 103.03509 & 637,000 & 3,602 & 1,800 & 12.934 & JMF & Thornhill Group, Inc., 2009 \\
\hline $\mathrm{T} 8$ & -- & S-26 & 2009 & 30.85883 & 103.03722 & 842,000 & 3,602 & 2,300 & 13.696 & JMF & Thornhill Group, Inc., 2009 \\
\hline T9 & -- & $\mathrm{C}-\mathrm{B} 2$ & 2009 & 30.89105 & 103.03141 & $1,070,000$ & 2,802 & 3,821 & 13.883 & JMF & Thornhill Group, Inc., 2009 \\
\hline $\mathrm{T} 10$ & -- & $\mathrm{C}-3$ & 2009 & 30.89123 & 103.03452 & $1,216,000$ & 2,702 & 4,500 & 14.011 & JMF & Thornhill Group, Inc., 2009 \\
\hline T11 & -- & S-33 & 2007 & 30.91737 & 102.61213 & 96,000 & -- & -- & 11.472 & JMF & Thornhill Group, Inc., 2008 \\
\hline $\mathrm{T} 13$ & -- & -- & 1957 & 30.88750 & 102.89194 & 18,100 & 2,803 & 65 & 9.804 & TNEF & Meyers, 1969, p. 408 \\
\hline $\mathrm{T} 14$ & -- & -- & 1957 & 30.89250 & 102.90222 & 7,000 & 1,603 & 44 & 8.854 & TRF & Meyers, 1969, p. 408 \\
\hline T15 & -- & -- & 1957 & 30.96944 & 102.88167 & 4,580 & 2,103 & 22 & 8.429 & TNEF & Meyers, 1969, p. 411 \\
\hline $\mathrm{T} 16$ & -- & -- & 1957 & 30.95611 & 102.88556 & 5,640 & 2,203 & 26 & 8.638 & $\mathrm{JMF}$ & Meyers, 1969, p. 411 \\
\hline $\mathrm{T} 17$ & -- & -- & 1957 & 30.96778 & 102.88472 & 2,800 & 1,203 & 23 & 7.937 & TRF & Meyers, 1969, p. 412 \\
\hline $\mathrm{T} 18$ & -- & -- & 1957 & 30.96667 & 102.89444 & 7,150 & 1,803 & 40 & 8.875 & TNEF & Meyers, 1969, p. 412 \\
\hline T19 & -- & -- & 1959 & 31.02028 & 103.55000 & 8,260 & 203 & 413 & 9.019 & $\mathrm{JMF}$ & Meyers, 1969, p. 427 \\
\hline $\mathrm{T} 20$ & -- & Fritz & 2011 & 30.78740 & 103.44340 & 13,713 & 4,103 & 33 & 9.526 & $\mathrm{DF}$ & USGS \\
\hline $\mathrm{T} 26$ & 4561604 & -- & 1969 & 31.05110 & 102.37780 & 7,800 & 1,603 & 49 & 8.962 & $\mathrm{DF}$ & TWDB, 2011 \\
\hline $\mathrm{T} 27$ & 4561605 & -- & 1969 & 31.05360 & 102.37690 & 4,350 & 1,503 & 29 & 8.378 & $\mathrm{DF}$ & TWDB, 2011 \\
\hline $\mathrm{T} 28$ & 4561608 & -- & 1969 & 31.05060 & 102.38360 & 4,350 & 1,703 & 26 & 8.378 & $\mathrm{DF}$ & TWDB, 2011 \\
\hline $\mathrm{T} 29$ & 4561610 & -- & 1969 & 31.04390 & 102.39690 & 3,300 & 1,603 & 21 & 8.102 & $\mathrm{DF}$ & TWDB, 2011 \\
\hline $\mathrm{T} 30$ & 4561901 & -- & 1968 & 31.03360 & 102.39000 & 1,800 & 1,803 & 10 & 7.496 & $\mathrm{DF}$ & TWDB, 2011 \\
\hline $\mathrm{T} 31$ & 4561902 & -- & 1968 & 31.03000 & 102.38940 & 2,850 & 1,703 & 17 & 7.955 & $\mathrm{DF}$ & TWDB, 2011 \\
\hline $\mathrm{T} 32$ & 4561903 & -- & 1968 & 31.02810 & 102.38670 & 4,350 & 1,703 & 26 & 8.378 & $\mathrm{DF}$ & TWDB, 2011 \\
\hline $\mathrm{T} 33$ & 4561904 & -- & 1968 & 31.02690 & 102.38830 & 4,650 & 1,703 & 27 & 8.445 & $\mathrm{DF}$ & TWDB, 2011 \\
\hline $\mathrm{T} 34$ & 4561905 & -- & 1968 & 31.02440 & 102.38940 & 2,700 & 1,703 & 16 & 7.901 & DF & TWDB, 2011 \\
\hline $\mathrm{T} 35$ & 5216302 & -- & 2007 & 30.85190 & 103.02560 & 73,500 & 2,603 & 283 & 11.205 & $\mathrm{DF}$ & TWDB, 2011 \\
\hline $\mathrm{T} 36$ & 5216308 & -- & 2007 & 30.84500 & 103.03440 & 192,000 & 2,403 & 800 & 12.165 & $\mathrm{DF}$ & TWDB, 2011 \\
\hline $\mathrm{T} 37$ & 5216309 & -- & 2007 & 30.86390 & 103.03250 & 609,000 & 5,303 & 1,149 & 13.320 & $\mathrm{DF}$ & TWDB, 2011 \\
\hline $\mathrm{T} 38$ & 5216603 & -- & 2007 & 30.83060 & 103.02610 & 265,500 & 2,203 & 1,207 & 12.489 & $\mathrm{DF}$ & TWDB, 2011 \\
\hline T39 & 5216618 & -- & 2007 & 30.83030 & 103.03030 & 436,500 & 2,503 & 1,746 & 12.987 & $\mathrm{DF}$ & TWDB, 2011 \\
\hline $\mathrm{T} 40$ & 5216619 & -- & 2007 & 30.79310 & 103.00610 & 87,000 & 1,203 & 725 & 11.374 & $\mathrm{DF}$ & TWDB, 2011 \\
\hline $\mathrm{T} 41$ & 5305301 & -- & 2001 & 30.99670 & 102.37560 & 6,600 & 1,703 & 39 & 8.795 & DF & TWDB, 2011 \\
\hline $\mathrm{T} 42$ & 5305903 & -- & 1973 & 30.89500 & 102.37690 & 9,375 & 1,003 & 94 & 9.146 & DF & TWDB, 2011 \\
\hline $\mathrm{T} 45$ & 5313203 & -- & 2000 & 30.83860 & 102.44970 & 1,920 & 503 & 38 & 7.560 & DF & TWDB, 2011 \\
\hline $\mathrm{T} 46$ & 5313209 & -- & 1999 & 30.84470 & 102.45560 & 1,500 & 603 & 25 & 7.313 & DF & TWDB, 2011 \\
\hline
\end{tabular}

${ }^{1}$ Unknown well completion depth; assumed $400 \mathrm{ft}$ below land surface for site $\mathrm{T} 2$ and assumed $500 \mathrm{ft}$ below land surface for site T5.

${ }^{2}$ Thickness from Thornhill Group, Inc., 2009 report.

${ }^{3}$ Thickness approximated from water level and interpreted base of aquifer (rounded to nearest $10 \mathrm{ft}$ ). 
Table 5. Data-collection sites providing data for the geochemical analysis in the Pecos County region study area, Texas.

[USGS, U.S. Geological Survey; --, not applicable; ET, Edwards-Trinity; PC QW, Pecos County water quality]

\begin{tabular}{|c|c|c|c|c|c|c|c|}
\hline $\begin{array}{c}\text { Site } \\
\text { identi- } \\
\text { fier } \\
\text { (fig. 20) }\end{array}$ & $\begin{array}{l}\text { USGS } \\
\text { station name }\end{array}$ & $\begin{array}{c}\text { State } \\
\text { well number }\end{array}$ & $\begin{array}{c}\text { USGS } \\
\text { station number }\end{array}$ & $\begin{array}{l}\text { Latitude } \\
\text { (decimal } \\
\text { degrees) }\end{array}$ & $\begin{array}{c}\text { Longitude } \\
\text { (decimal } \\
\text { degrees) }\end{array}$ & $\begin{array}{l}\text { Site } \\
\text { type }\end{array}$ & $\begin{array}{l}\text { Contributing } \\
\text { aquifer }\end{array}$ \\
\hline Q2 & Santa Rosa Spring & -- & 08437000 & 31.26743 & 102.95828 & Spring & -- \\
\hline Q4 & Comanche Springs & -- & 08444500 & 30.88628 & 102.87495 & Spring & -- \\
\hline Q27 & PS-52-02-404 & PS-52-02-404 & 305502103504101 & 30.91737 & 103.84518 & Well & Pecos Valley \\
\hline Q36 & WD-46-62-201 & WD-46-62-201 & 310625103175201 & 31.10685 & 103.29777 & Well & Pecos Valley \\
\hline Q42 & US-45-43-807 & US-45-43-807 & 311602102400601 & 31.26942 & 102.67609 & Well & Pecos Valley \\
\hline Q43 & US-45-43-8xx (PA 1) & US-45-43-8xx & 311602102400901 & 31.26934 & 102.68214 & Well & Pecos Valley \\
\hline Q15 & PS-52-11-702 & PS-52-11-702 & 304605103444601 & 30.77100 & 103.74800 & Well & Igneous \\
\hline Q14 & US-53-17-501 & US-53-17-501 & 304117102560101 & 30.68806 & 102.93361 & Well & Edwards-Trinity \\
\hline Q16 & US-52-16-910 & US-52-16-910 & 304646103013401 & 30.77931 & 103.02615 & Well & Edwards-Trinity \\
\hline Q17 & US-52-13-801 & US-52-13-801 & 304715103263501 & 30.78740 & 103.44343 & Well & Edwards-Trinity \\
\hline Q18 & US-52-16-611 & US-52-16-611 & 304802103003901 & 30.80088 & 103.01110 & Well & Edwards-Trinity \\
\hline Q22 & US-52-16-3xx (S-21) & US-52-16-3xx & 305132103015701 & 30.85899 & 103.03244 & Well & Edwards-Trinity \\
\hline Q23 & US-53-09-306 & US-53-09-306 & 305140102521101 & 30.87393 & 102.88229 & Well & Edwards-Trinity \\
\hline Q24 & US-52-08-909 & US-52-08-909 & 305331103020501 & 30.89210 & 103.03516 & Well & Edwards-Trinity \\
\hline Q25 & US-53-03-9xx & US-53-03-9xx & 305354102373501 & 30.89825 & 102.62647 & Well & Edwards-Trinity \\
\hline Q26 & US-53-01-907 & US-53-01-907 & 305419102545301 & 30.90560 & 102.91610 & Well & Edwards-Trinity \\
\hline Q40 & US-46-56-309 & US-46-56-309 & 311235103000901 & 31.20974 & 103.00262 & Well & Edwards-Trinity \\
\hline Q8 & $\begin{array}{l}\text { BK-52-29-8xx (Brewster County } \\
\text { ET Well) }\end{array}$ & BK-52-29-8xx & 303222103263701 & 30.53950 & 103.44346 & Well & Edwards-Trinity \\
\hline Q9 & US-52-07-502 & US-52-07-502 & 303342103064001 & 30.93779 & 103.18711 & Well & Edwards-Trinity \\
\hline Q21 & US-53-13-208 & US-53-13-208 & 305112102265901 & 30.85341 & 102.44965 & Well & Dockum \\
\hline Q31 & US-52-06-603 & US-52-06-603 & 305559103154101 & 30.93305 & 103.26194 & Well & Dockum \\
\hline Q34 & US-53-01-208 & US-53-01-208 & 305949102552301 & 30.99718 & 102.92291 & Well & Dockum \\
\hline Q39 & US-46-55-9xx (Weatherby Ranch) & US-46-55-9xx & 310949103090401 & 31.16341 & 103.15103 & Well & Dockum \\
\hline Q44 & US-46-48-701 & US-46-48-701 & 311610103050901 & 31.26959 & 103.08683 & Well & Dockum \\
\hline Q10 & US-53-19-7xx (PC QW) & US-53-19-7xx & 303852102432902 & 30.64799 & 102.72470 & Well & Rustler \\
\hline Q13 & US-52-24-501 & US-52-24-501 & 304020103025202 & 30.67295 & 103.05601 & Well & Rustler \\
\hline Q19 & US-52-16-609 & US-52-16-609 & 304805103013301 & 30.80129 & 103.02618 & Well & Rustler \\
\hline Q29 & US-53-01-5xx (Apache 3) & US-53-01-5xx & 305529102560601 & 30.92470 & 102.93490 & Well & Rustler \\
\hline Q38 & WD-46-54-901 & WD-46-54-901 & 310806103171901 & 31.13502 & 103.28796 & Well & Rustler \\
\hline Q20 & US-52-16-504 & US-52-16-504 & 304807103025301 & 30.80241 & 103.04844 & Well & Capitan Reef \\
\hline Q41 & US-45-49-203 & US-45-49-203 & 311422102555101 & 31.23974 & 102.93097 & Well & Capitan Reef \\
\hline
\end{tabular}


Table 6. Contributing-aquifer revisions for groundwater wells providing data for the geochemical analysis based on the comparison of well production depths with the hydrostratigraphy of hydrogeologic framework for the Pecos County region study area, Texas.

[USGS, U.S. Geological Survey]

\begin{tabular}{cccc}
\hline $\begin{array}{c}\text { Site identifier } \\
\text { (fig. 20) }\end{array}$ & $\begin{array}{c}\text { USGS } \\
\text { station number }\end{array}$ & $\begin{array}{c}\text { Previously identified contributing aquifer } \\
\text { (Pearson and others, 2012) }\end{array}$ & $\begin{array}{c}\text { Updated } \\
\text { contributing aquifer }\end{array}$ \\
\hline Q12 & 304006103315601 & Igneous & Edwards-Trinity \\
Q30 & 305531103474201 & Cretaceous Undivided & Edwards-Trinity \\
Q40 & 311235103000901 & Pecos Valley & Edwards-Trinity \\
Q21 & 305112102265901 & Edwards-Trinity & Dockum \\
Q31 & 305559103154101 & Edwards-Trinity & Dockum \\
Q34 & 305949102552301 & Edwards-Trinity & Dockum \\
Q39 & 310949103090401 & Edwards-Trinity & Dockum \\
Q10 & 303852102432902 & Edwards-Trinity & Rustler \\
Q13 & 304020103025202 & Edwards-Trinity & Rustler \\
\hline
\end{tabular}


Table 7. Summary of selected physical properties and constituents measured in groundwater and spring water samples and hydrochemical facies, Pecos County region study area, Texas.

[USGS, U.S. Geological Survey; $\mu \mathrm{S} / \mathrm{cm}$, microsiemens per centimeter at 25 degrees Celsius; $\mathrm{mg} / \mathrm{L}$, milligrams per liter; $\mu \mathrm{g} / \mathrm{L}$, micrograms per liter; $\delta^{18} \mathrm{O}$, delta oxygen-18; $\delta \mathrm{D}$, delta deuterium; ${ }^{87} \mathrm{Sr}{ }^{86} \mathrm{Sr}$, strontium-87/strontium-86; CIAT, Deethylatrazine; $\mathrm{Na}$, sodium; Ca, calcium; $\mathrm{Mg}$, magnesium; Cl, chloride; SO , sulfate; $\mathrm{HCO}_{3}$, bicarbonate; --, not available; E, estimated; <, nondetection less than laboratory reporting level]

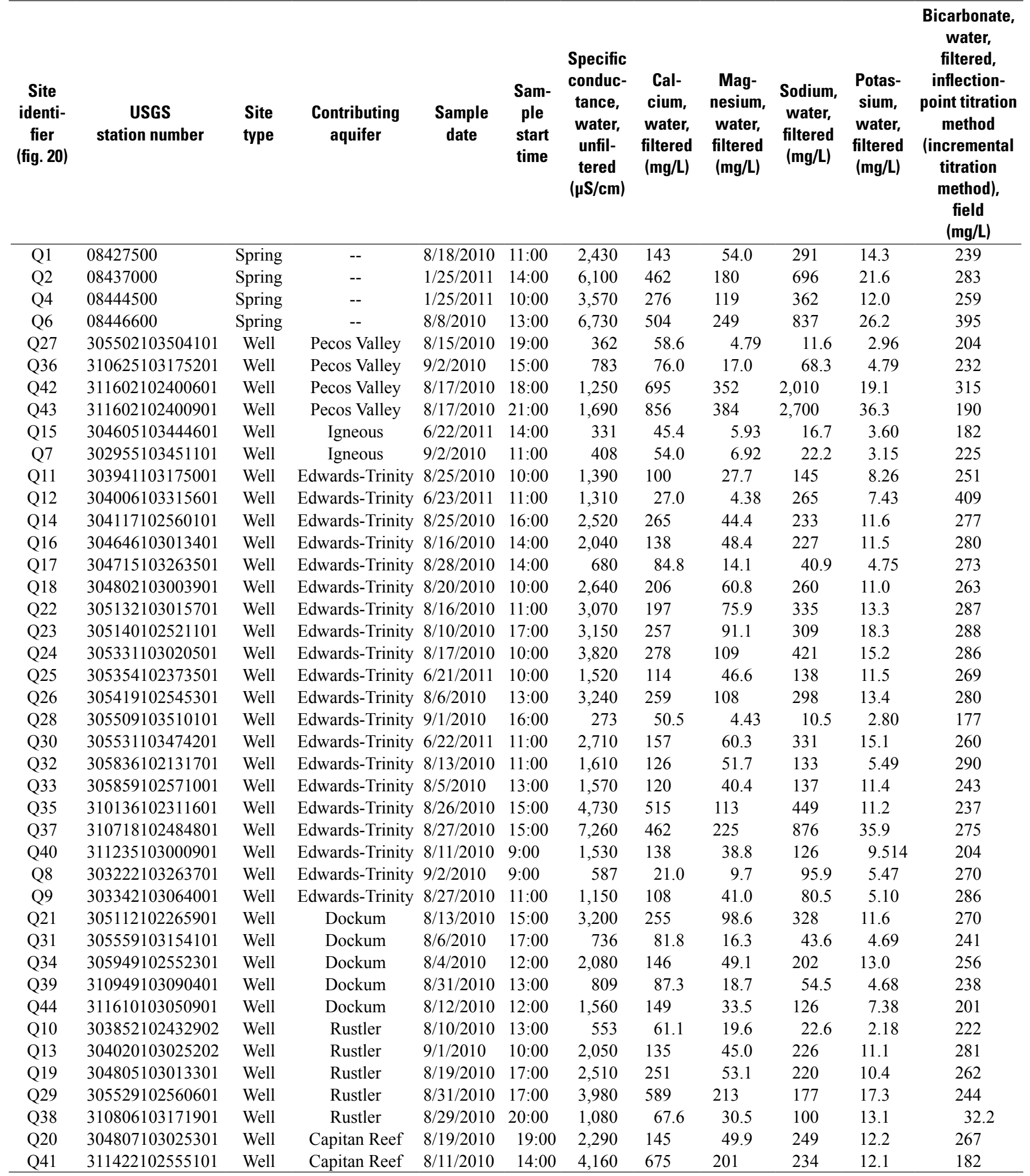


Table 7. Summary of selected physical properties and constituents measured in groundwater and spring water samples and hydrochemical facies, Pecos County region study area, Texas.-Continued

[USGS, U.S. Geological Survey; $\mu \mathrm{S} / \mathrm{cm}$, microsiemens per centimeter at 25 degrees Celsius; $\mathrm{mg} / \mathrm{L}$, milligrams per liter; $\mu \mathrm{g} / \mathrm{L}$, micrograms per liter; $\delta^{18} \mathrm{O}$, delta oxygen-18; $\delta \mathrm{D}$, delta deuterium; ${ }^{87} \mathrm{Sr} /{ }^{86} \mathrm{Sr}$, strontium-87/strontium-86; CIAT, Deethylatrazine; $\mathrm{Na}$, sodium; $\mathrm{Ca}$, calcium; $\mathrm{Mg}$, magnesium; Cl, chloride; $\mathrm{SO}$, sulfate; $\mathrm{HCO}_{3}$, bicarbonate; --, not available; E, estimated; <, nondetection less than laboratory reporting level]

\begin{tabular}{|c|c|c|c|c|c|c|c|c|c|c|c|c|}
\hline $\begin{array}{c}\text { Site } \\
\text { identi- } \\
\text { fier } \\
\text { (fig. 20) }\end{array}$ & $\begin{array}{c}\text { Sulfate, } \\
\text { water, } \\
\text { filtered } \\
(\mathrm{mg} / \mathrm{L})\end{array}$ & $\begin{array}{c}\text { Chloride, } \\
\text { water, } \\
\text { filtered } \\
(\mathrm{mg} / \mathrm{L})\end{array}$ & $\begin{array}{c}\text { Silica, } \\
\text { water, } \\
\text { filtered } \\
\text { (mg/L as } \\
\text { silicon } \\
\text { dioxide) }\end{array}$ & $\begin{array}{c}\text { Nitrate } \\
\text { plus } \\
\text { Nitrite, } \\
\text { water, } \\
\text { filtered } \\
\text { (mg/L) }\end{array}$ & $\begin{array}{c}\text { Dis- } \\
\text { solved } \\
\text { oxygen } \\
\text { (mg/L) }\end{array}$ & $\begin{array}{l}\text { Hydrochemical } \\
\text { facies }\end{array}$ & $\begin{array}{c}\delta^{18} 0 \\
\text { (per mil) } \\
\text { (fig. 23) }\end{array}$ & $\begin{array}{c}\delta \text { D } \\
\text { (per } \\
\text { mil) }\end{array}$ & $\begin{array}{l}{ }^{87} \mathrm{Sr} /{ }^{86} \mathrm{Sr} \\
\text { (fig. 25) }\end{array}$ & $\begin{array}{c}\text { Stron- } \\
\text { tium, } \\
\text { water, } \\
\text { filtered } \\
(\mu \mathrm{g} / \mathrm{L})\end{array}$ & $\begin{array}{l}\text { Atrazine } \\
(\mu \mathrm{g} / \mathrm{L})\end{array}$ & $\begin{array}{l}\text { CIAT } \\
(\mu \mathrm{g} / \mathrm{L})\end{array}$ \\
\hline Q1 & 437 & 431 & 24.6 & 0.788 & 3.47 & $\mathrm{Na}-\mathrm{Ca}-\mathrm{Cl}-\mathrm{SO}_{4}$ & -8.30 & -58.1 & 0.70991 & 2,340 & -- & -- \\
\hline Q2 & 1,550 & 1,180 & 32.8 & 2.95 & 4.19 & Na-Ca-Mg-Cl-SO & -6.56 & -47.0 & 0.70925 & 9,060 & -- & -- \\
\hline Q4 & 987 & 565 & 22.8 & 5.74 & 2.10 & $\mathrm{Na}-\mathrm{Ca}-\mathrm{Mg}-\mathrm{SO}_{4}-\mathrm{Cl}$ & -7.45 & -50.5 & 0.70898 & 6,230 & 0.0064 & E0.0141 \\
\hline Q6 & 1,890 & 1,220 & 35.4 & 6.67 & 6.35 & $\mathrm{Na}-\mathrm{Ca}-\mathrm{Mg}-\mathrm{SO}_{4}-\mathrm{Cl}$ & -6.83 & -49.5 & 0.70970 & 8,970 & $<0.007$ & E0.0213 \\
\hline Q27 & 11.8 & 7.16 & 53.5 & 1.22 & 6.14 & $\mathrm{Ca}-\mathrm{HCO}_{3}$ & -6.84 & -46.3 & 0.70799 & 240 & -- & -- \\
\hline Q36 & 115 & 70.4 & 33.8 & 0.964 & 5.83 & $\mathrm{Ca}-\mathrm{Na}-\mathrm{HCO}_{3}-\mathrm{SO}_{4}-\mathrm{Cl}$ & -6.85 & -46.2 & 0.70839 & 1,300 & -- & -- \\
\hline Q42 & 2,600 & 3,930 & 25.8 & $<0.04$ & 1.02 & $\mathrm{Na}-\mathrm{Ca}-\mathrm{Cl}-\mathrm{SO}_{4}$ & -4.86 & -39.9 & 0.70813 & 12,300 & -- & -- \\
\hline Q43 & 3,020 & 4,770 & 22.6 & 2.10 & 2.73 & $\mathrm{Na}-\mathrm{Ca}-\mathrm{Cl}_{-}-\mathrm{SO}_{4}$ & -2.21 & -26.0 & 0.70813 & 15,000 & -- & -- \\
\hline Q15 & 16.0 & 8.81 & 43.4 & 0.184 & 7.96 & $\mathrm{Ca}-\mathrm{Na}-\mathrm{HCO}_{3}{ }^{4}$ & -6.12 & -44.6 & 0.70757 & 257 & $<0.008$ & $<0.006$ \\
\hline Q7 & 12.9 & 8.39 & 43.6 & 0.632 & 4.44 & $\mathrm{Ca}-\mathrm{Na}-\mathrm{HCO}_{3}$ & -6.23 & -41.6 & 0.70727 & 198 & -- & -- \\
\hline Q11 & 222 & 195 & 28.4 & 0.207 & 0.216 & $\mathrm{Na}-\mathrm{Ca}-\mathrm{Cl}-\mathrm{SO}_{4}-\mathrm{HCO}_{3}$ & -7.29 & -50.1 & 0.70954 & 1,730 & -- & -- \\
\hline Q12 & 271 & 58.6 & 21.1 & $<0.02$ & 0.280 & $\mathrm{Na}-\mathrm{HCO}_{3}-\mathrm{SO}_{4}$ & -7.47 & -50.2 & 0.70788 & 1,030 & $<0.008$ & $<0.006$ \\
\hline Q14 & 661 & 340 & 20.8 & $<0.04$ & 0.306 & $\mathrm{Ca}-\mathrm{Na}-\mathrm{SO}_{4}-\mathrm{Cl}$ & -7.89 & -55.0 & 0.70893 & 3,610 & -- & -- \\
\hline Q16 & 341 & 317 & 20.2 & 0.309 & 0.897 & $\mathrm{Na}-\mathrm{Ca}-\mathrm{Cl}-\mathrm{SO}_{4}-\mathrm{HCO}_{3}$ & -7.82 & -54.1 & 0.70975 & 2,140 & -- & -- \\
\hline Q17 & 57.7 & 50.8 & 26.7 & 0.832 & 1.28 & $\mathrm{Ca}-\mathrm{Na}-\mathrm{HCO}_{3}$ & -6.97 & -45.6 & 0.70830 & 754 & -- & -- \\
\hline Q18 & 546 & 438 & 19.9 & 3.53 & E1.171 & $\mathrm{Na}-\mathrm{Ca}-\mathrm{Cl}-\mathrm{SO}_{4}$ & -7.70 & -54.2 & 0.70901 & 4,170 & $<0.007$ & E0.0065 \\
\hline Q22 & 578 & 556 & 22.7 & 1.58 & 0.921 & $\mathrm{Na}-\mathrm{Ca}-\mathrm{Cl}-\mathrm{SO}_{4}$ & -7.78 & -53.9 & 0.70974 & 3,710 & -- & -- \\
\hline Q23 & 807 & 502 & 22.8 & 4.51 & 2.97 & $\mathrm{Na}-\mathrm{Ca}-\mathrm{Mg}-\mathrm{SO}_{4}-\mathrm{Cl}$ & -7.18 & -47.5 & 0.70940 & 7,320 & -- & -- \\
\hline Q24 & 908 & 758 & 23.3 & 1.61 & 1.17 & $\mathrm{Na}-\mathrm{Ca}-\mathrm{Mg}-\mathrm{Cl}-\mathrm{SO}_{4}$ & -7.47 & -52.3 & 0.70963 & 5,330 & $<0.007$ & E0.0075 \\
\hline Q25 & 277 & 203 & 10.6 & $<0.02$ & 0.770 & $\begin{array}{c}\mathrm{Na}-\mathrm{Ca}-\mathrm{Mg}_{-}-\mathrm{SO}_{4}-\mathrm{Cl}- \\
\mathrm{HCO}_{3}\end{array}$ & -7.47 & -49.6 & 0.70959 & 2,370 & $<0.008$ & $<0.006$ \\
\hline Q26 & 883 & 470 & 19.7 & 4.04 & 1.43 & $\mathrm{Na}-\mathrm{Ca}-\mathrm{Mg}-\mathrm{SO}_{4}-\mathrm{Cl}$ & -7.06 & -48.8 & 0.70904 & 5,300 & 0.017 & E0.013 \\
\hline Q28 & 12.2 & 5.16 & 52.0 & 1.18 & 4.48 & $\mathrm{Ca}-\mathrm{HCO}_{3}$ & -6.72 & -45.3 & 0.70807 & 215 & -- & -- \\
\hline Q30 & 498 & 473 & 20.8 & 0.135 & 0.450 & $\mathrm{Na}-\mathrm{Ca}-\mathrm{Cl}-\mathrm{SO}_{4}$ & -8.34 & -57.7 & 0.70979 & 2,720 & $<0.008$ & $<0.006$ \\
\hline Q32 & 217 & 240 & 18.3 & 1.81 & 6.32 & $\begin{array}{c}\mathrm{Ca}-\mathrm{Na}-\mathrm{Mg}-\mathrm{Cl}-\mathrm{HCO}_{3}- \\
\mathrm{SO}_{4}\end{array}$ & -6.75 & -44.5 & 0.70853 & 2,150 & -- & -- \\
\hline Q33 & 238 & 247 & 10.4 & $<0.04$ & 0.180 & $\begin{array}{c}\mathrm{Ca}-\mathrm{Na}-\mathrm{Mg}-\mathrm{Cl}-\mathrm{SO}_{4}{ }^{-} \\
\mathrm{HCO}_{3}\end{array}$ & -7.50 & -50.6 & 0.70961 & 2,250 & -- & -- \\
\hline Q35 & 1,510 & 783 & 12.2 & $<0.04$ & 0.447 & $\mathrm{Ca}-\mathrm{Na}-\mathrm{SO}_{4}-\mathrm{Cl}$ & -7.24 & -50.7 & 0.70824 & 8,790 & -- & -- \\
\hline Q37 & 2,010 & 1,370 & 28.3 & 0.391 & 2.99 & $\mathrm{Na}-\mathrm{Ca}-\mathrm{Mg}-\mathrm{SO}_{4}-\mathrm{Cl}$ & -6.85 & -48.6 & 0.70969 & 10,300 & -- & -- \\
\hline Q40 & 376 & 180 & 13.0 & $<0.04$ & E0.230 & $\mathrm{Ca}-\mathrm{Na}-\mathrm{SO}_{4}-\mathrm{Cl}-\mathrm{HCO}_{3}$ & -7.33 & -50.0 & 0.70877 & 3,080 & -- & -- \\
\hline Q8 & 56.0 & 15.9 & 14.3 & $<0.04$ & 0.149 & $\mathrm{Na}-\mathrm{HCO}_{3}$ & -7.16 & -49.0 & 0.70816 & 575 & -- & -- \\
\hline Q9 & 276 & 55.9 & 25.5 & 5.74 & 3.93 & $\mathrm{Ca}-\mathrm{Na}-\mathrm{Mg}-\mathrm{SO}_{4}-\mathrm{HCO}_{3}$ & -6.42 & -44.6 & 0.70823 & 257 & -- & -- \\
\hline Q21 & 586 & 675 & 16.2 & 5.63 & 4.45 & $\mathrm{Na}-\mathrm{Ca}-\mathrm{Mg}-\mathrm{Cl}-\mathrm{SO}_{4}$ & -7.14 & -48.1 & 0.70906 & 4,040 & -- & -- \\
\hline Q31 & 91.8 & 58.2 & 14.4 & $<0.04$ & 0.140 & $\mathrm{Ca}-\mathrm{Na}-\mathrm{HCO}_{3}-\mathrm{SO}_{4}-\mathrm{Cl}$ & -6.87 & -46.3 & 0.70843 & 1,000 & -- & -- \\
\hline Q34 & 335 & 331 & 11.1 & $<0.04$ & 0.140 & $\mathrm{Na}-\mathrm{Ca}-\mathrm{Cl}-\mathrm{SO}_{4}-\mathrm{HCO}_{3}$ & -7.81 & -53.0 & 0.70975 & 2,610 & -- & -- \\
\hline Q39 & 119 & 68.1 & 26.3 & 1.09 & 7.32 & $\mathrm{Ca}-\mathrm{Na}-\mathrm{HCO}_{3}-\mathrm{SO}_{4}-\mathrm{Cl}$ & -6.81 & -47.2 & 0.70854 & 1,350 & -- & -- \\
\hline Q44 & 346 & 195 & 30.9 & 2.43 & 4.41 & $\mathrm{Ca}-\mathrm{Na}-\mathrm{SO}_{4}-\mathrm{Cl}-\mathrm{HCO}_{3}$ & -7.21 & -48.5 & 0.70882 & 2,800 & $<0.007$ & $<0.014$ \\
\hline Q10 & 52.5 & 23.5 & 14.0 & 2.19 & 4.03 & $\mathrm{Ca}-\mathrm{Mg}-\mathrm{HCO}_{3}$ & -6.66 & -45.1 & 0.70829 & 772 & -- & -- \\
\hline Q13 & 357 & 323 & 19.6 & $<0.04$ & 0.0740 & $\mathrm{Na}-\mathrm{Ca}-\mathrm{Cl}-\mathrm{SO}_{4}-\mathrm{HCO}_{3}$ & -7.84 & -53.3 & 0.70977 & 2,200 & -- & -- \\
\hline Q19 & 704 & 332 & 18.7 & $<0.04$ & E0.170 & $\mathrm{Ca}-\mathrm{Na}-\mathrm{SO}_{4}-\mathrm{Cl}$ & -7.89 & -53.2 & 0.70867 & 3,190 & -- & -- \\
\hline Q29 & 2,270 & 179 & 14.0 & $<0.04$ & 6.57 & $\mathrm{Ca}-\mathrm{Mg}-\mathrm{SO}_{4}$ & -7.61 & -52.7 & 0.70758 & 10,000 & -- & -- \\
\hline Q38 & 354 & 110 & 0.479 & $<0.04$ & 0.129 & $\mathrm{Na}-\mathrm{Ca}-\mathrm{Mg}-\mathrm{SO}_{4}-\mathrm{Cl}$ & -6.83 & -47.6 & 0.70763 & 3,390 & -- & -- \\
\hline Q20 & 421 & 370 & 21.0 & $<0.04$ & Е 0.252 & $\mathrm{Na}-\mathrm{Ca}-\mathrm{Cl}-\mathrm{SO}_{4}$ & -7.92 & -54.9 & 0.70969 & 2,650 & -- & -- \\
\hline Q41 & 2,320 & 354 & 13.9 & $<0.04$ & 1.25 & $\mathrm{Ca}-\mathrm{Mg}-\mathrm{SO}_{4}$ & -7.74 & -52.8 & 0.70751 & 10,200 & -- & -- \\
\hline
\end{tabular}


Table 8. Tritium concentrations and helium-4 screen interpretations for groundwater samples collected in the Pecos County region study area, Texas.

[USGS, U.S. Geological Survey; pCi/L, picocuries per liter; TU, tritium units (3.22 pCi/L = $1 \mathrm{TU})$; --, not available; ssLc, sample specific critical level; $\mathrm{R}$, radiochemical nondetect]

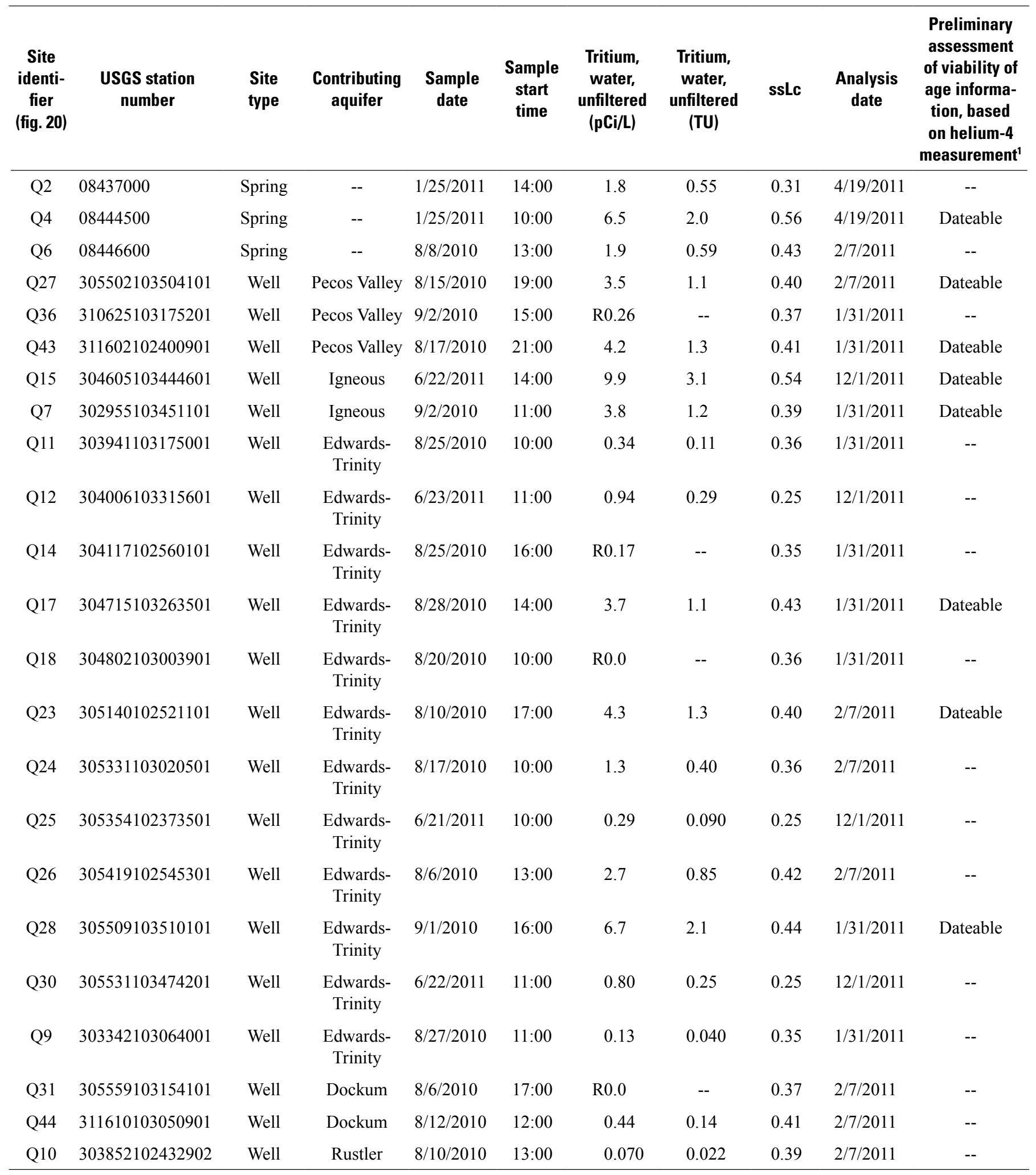

${ }^{1}$ Dateable refers to the potential for obtaining valid groundwater age information based on preliminary results. 
Table 9. Average winter (November through April) groundwater-level data used for the 1980-2010 compiled potentiometric-surface map of the Edwards-Trinity aquifer in the Pecos County region study area, Texas.

[TWDB, Texas Water Development Board]

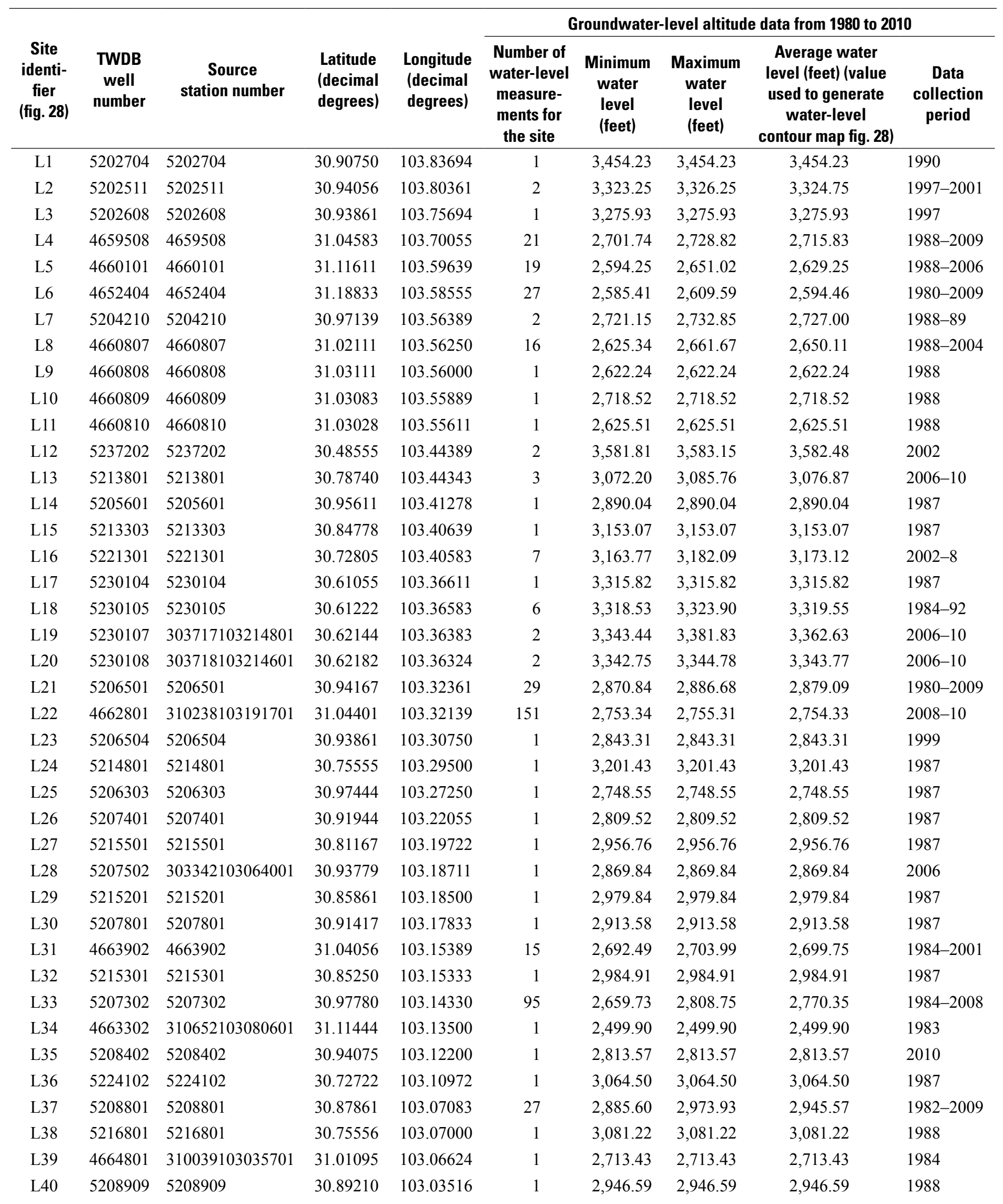


Table 9. Average winter (November through April) groundwater-level data used for the 1980-2010 compiled potentiometric-surface map of the Edwards-Trinity aquifer in the Pecos County region study area, Texas. - Continued

[TWDB, Texas Water Development Board]

\begin{tabular}{|c|c|c|c|c|c|c|c|c|c|}
\hline \multirow[b]{2}{*}{$\begin{array}{c}\text { Site } \\
\text { identi- } \\
\text { fier } \\
\text { (fig. 28) }\end{array}$} & \multirow[b]{2}{*}{$\begin{array}{c}\text { TWDB } \\
\text { well } \\
\text { number }\end{array}$} & \multirow[b]{2}{*}{$\begin{array}{c}\text { Source } \\
\text { station number }\end{array}$} & \multirow[b]{2}{*}{$\begin{array}{l}\text { Latitude } \\
\text { (decimal } \\
\text { degrees) }\end{array}$} & \multirow[b]{2}{*}{$\begin{array}{c}\text { Longitude } \\
\text { (decimal } \\
\text { degrees) }\end{array}$} & \multicolumn{5}{|c|}{ Groundwater-level altitude data from 1980 to 2010} \\
\hline & & & & & $\begin{array}{c}\text { Number of } \\
\text { water-level } \\
\text { measure- } \\
\text { ments for } \\
\text { the site }\end{array}$ & $\begin{array}{l}\text { Minimum } \\
\text { water } \\
\text { level } \\
\text { (feet) }\end{array}$ & $\begin{array}{l}\text { Maximum } \\
\text { water } \\
\text { level } \\
\text { (feet) }\end{array}$ & $\begin{array}{l}\text { Average water } \\
\text { level (feet) (value } \\
\text { used to generate } \\
\text { water-level } \\
\text { contour map fig. 28) }\end{array}$ & $\begin{array}{c}\text { Data } \\
\text { collection } \\
\text { period }\end{array}$ \\
\hline L41 & 5216907 & 5216907 & 30.78694 & 103.03083 & 1 & $3,003.25$ & $3,003.25$ & $3,003.25$ & 1987 \\
\hline $\mathrm{L} 43$ & 5208905 & 5208905 & 30.88694 & 103.02972 & 1 & $2,942.07$ & $2,942.07$ & $2,942.07$ & 1988 \\
\hline L44 & 5208906 & 5208906 & 30.89167 & 103.02889 & 1 & $2,945.58$ & $2,945.58$ & $2,945.58$ & 1988 \\
\hline L45 & 5216605 & 5216605 & 30.80861 & 103.02694 & 2 & $2,970.33$ & $2,977.41$ & $2,973.87$ & 1988-2001 \\
\hline L46 & 5216304 & 5216304 & 30.84528 & 103.01861 & 1 & $2,978.68$ & $2,978.68$ & $2,978.68$ & 1988 \\
\hline L47 & 5216303 & 5216303 & 30.84556 & 103.01194 & 7 & $2,852.62$ & $3,050.52$ & $2,956.78$ & $1980-89$ \\
\hline L51 & 5309105 & 5309105 & 30.84528 & 102.99917 & 22 & $2,944.41$ & $2,983.42$ & $2,967.17$ & 1980-2008 \\
\hline L52 & 5309102 & 5309102 & 30.86833 & 102.98944 & 1 & $2,943.88$ & $2,943.88$ & $2,943.88$ & 1988 \\
\hline L53 & 5301102 & 5301102 & 30.99222 & 102.96583 & 1 & $2,706.66$ & $2,706.66$ & $2,706.66$ & 1993 \\
\hline L54 & 5301101 & 5301101 & 30.99556 & 102.96528 & 1 & $2,701.78$ & $2,701.78$ & $2,701.78$ & 1993 \\
\hline L55 & 5325101 & 5325101 & 30.60417 & 102.96167 & 1 & $3,079.44$ & $3,079.44$ & $3,079.44$ & 1987 \\
\hline L56 & 4557805 & 4557805 & 31.02083 & 102.95611 & 1 & $2,698.51$ & $2,698.51$ & $2,698.51$ & 1993 \\
\hline L57 & 5301503 & 5301503 & 30.95426 & 102.95382 & 1 & $2,832.38$ & $2,832.38$ & $2,832.38$ & 2010 \\
\hline L58 & 5301206 & 5301206 & 30.98305 & 102.94611 & 1 & $2,740.54$ & $2,740.54$ & $2,740.54$ & 1993 \\
\hline L59 & 5301204 & 5301204 & 30.99778 & 102.94583 & 1 & $2,717.87$ & $2,717.87$ & $2,717.87$ & 1993 \\
\hline L66 & 5301202 & 5301202 & 30.98389 & 102.92000 & 3 & $2,767.04$ & $2,776.37$ & $2,773.00$ & $1991-93$ \\
\hline L67 & 4557802 & 4557802 & 31.00778 & 102.91833 & 1 & $2,774.30$ & $2,774.30$ & $2,774.30$ & 1993 \\
\hline L68 & 5301907 & 305419102545301 & 30.90560 & 102.91610 & 1 & $2,884.39$ & $2,884.39$ & $2,884.39$ & 1981 \\
\hline L69 & 5301305 & 5301305 & 30.99056 & 102.91333 & 1 & $2,741.86$ & $2,741.86$ & $2,741.86$ & 1993 \\
\hline L70 & 530103 & 530103 & 30.85472 & 102.90970 & 2 & $2,918.51$ & $2,936.43$ & $2,927.47$ & 2006 \\
\hline L71 & 5301607 & 5301607 & 30.95583 & 102.90861 & 1 & $2,799.53$ & $2,799.53$ & $2,799.53$ & 1993 \\
\hline $\mathrm{L} 72$ & 4557603 & 4557603 & 31.05667 & 102.90722 & 30 & $2,667.82$ & $2,681.03$ & $2,679.82$ & $2007-9$ \\
\hline $\mathrm{L} 73$ & 5309301 & 305110102533401 & 30.85286 & 102.89278 & 31 & $2,888.48$ & $2,936.40$ & $2,913.94$ & 1980-2010 \\
\hline L74 & 5301304 & 5301304 & 30.99194 & 102.89250 & 1 & $2,751.44$ & $2,751.44$ & $2,751.44$ & 1993 \\
\hline $\mathrm{L} 75$ & 4549301 & 4549301 & 31.20861 & 102.89139 & 24 & $2,472.26$ & $2,481.34$ & $2,477.28$ & 1980-2005 \\
\hline L76 & 4549902 & 4549902 & 31.12555 & 102.88805 & 1 & $2,546.64$ & $2,546.64$ & $2,546.64$ & 2004 \\
\hline $\mathrm{L} 77$ & 5301902 & 5301902 & 30.88972 & 102.88417 & 27 & $2,847.64$ & $2,929.56$ & $2,913.08$ & 1980-2009 \\
\hline L78 & 5301908 & 5301908 & 30.88952 & 102.88397 & 1 & $2,903.70$ & $2,903.70$ & $2,903.70$ & 2010 \\
\hline L79 & 530102 & 530102 & 30.87389 & 102.88250 & 2 & $2,901.83$ & $2,928.13$ & $2,914.98$ & $2006-8$ \\
\hline L80 & 5309306 & 5309306 & 30.87389 & 102.88222 & 1 & $2,891.41$ & $2,891.41$ & $2,891.41$ & 2007 \\
\hline
\end{tabular}


Table 9. Average winter (November through April) groundwater-level data used for the 1980-2010 compiled potentiometric-surface map of the Edwards-Trinity aquifer in the Pecos County region study area, Texas.-Continued

[TWDB, Texas Water Development Board]

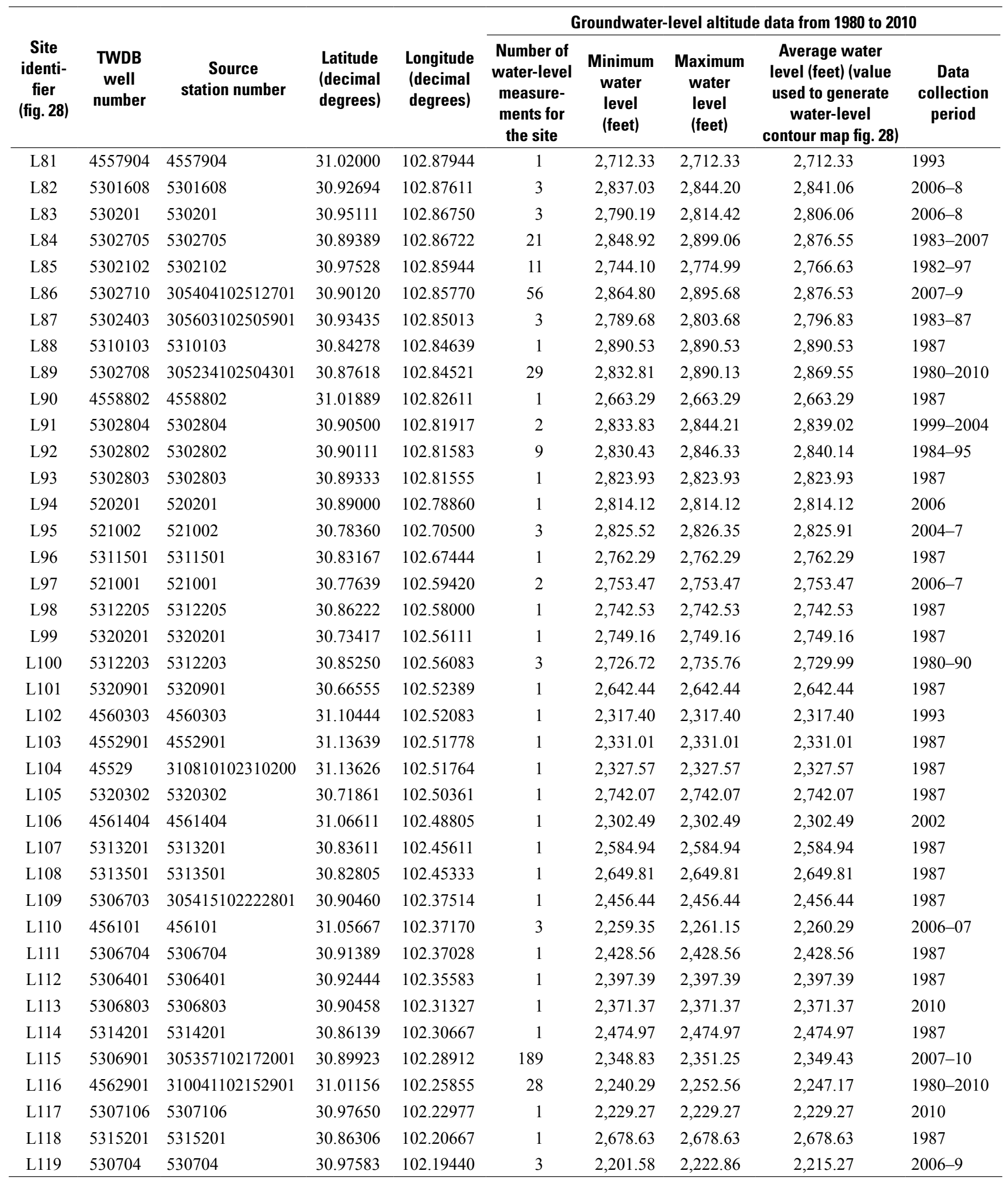


Publishing support provided by Lafayette Publishing Service Center

Information regarding water resources in Texas is available at http://tx.usgs.gov/ 
